\author{
UNIVERSIDADE DE SÃO PAULO \\ FACULDADE DE FILOSOFIA, LETRAS E CIÊNCIAS HUMANAS \\ DEPARTAMENTO DE LETRAS CLÁSSICAS E VERNÁCULAS \\ PROGRAMA DE PÓS-GRADUAÇÃO EM LITERATURA BRASILEIRA
}

\title{
Um resgate do Teatro Nacional \\ O Teatro Brasileiro nas revistas de São Paulo
}

(1901-1922)

\section{Maira Mariano}

Dissertação apresentada ao Programa de Pós-

Graduação em Literatura Brasileira, do

Departamento de Letras Clássicas e

Vernáculas, da Faculdade de Filosofia, Letras e

Ciências Humanas da Universidade de São

Paulo, para a obtenção do título de mestre em

Letras.

Orientador: Prof. Dr. João Roberto Gomes de Faria

\author{
São Paulo \\ 2008
}

Volume I 
Para os meus pais: Firmo e Jeanete

“Ando devagar porque já tive pressa Levo esse sorriso porque já chorei demais Hoje me sinto mais forte, mais feliz quem sabe, Só levo a certeza de que muito pouco eu sei, Nada sei. (Almir Satter e Renato Teixeira) 


\section{Agradecimentos}

“Um galo sozinho não tece uma manhã: ele precisará sempre de outros galos. De um que apanhe esse grito que ele e o lance a outro; de um outro galo que apanhe o grito de um galo antes

e o lance a outro; e de outros galos

que com muitos outros galos se cruzem os fios de sol de seus gritos de galo, para que a manhã, desde uma teia tênue, se vá tecendo, entre todos os galos".

(João Cabral de Melo Neto)

Tecer esse trabalho não teria sido possível sem o apoio e a colaboração de diversos "atores", que, envolvidos de diferentes maneiras, auxiliaram na sua composição. Assim sendo, não poderíamos dar por encerrado esse estudo, sem atribuir-Ihes o devido crédito.

Agradeço aos meus pais por priorizarem meus estudos (meu e de meus irmãos), pois sem esse esforço nada seria realizado.

Ao Hélio, principal incentivador, pelo amor, e por estar sempre a meu lado.

Agradeço ainda a confiança, o trabalho e a dedicação do meu orientador Prof. Dr. João Roberto Faria.

Aos meus amigos, que me apoiaram, ouviram minhas lamentações, dúvidas e comemorações. Aos colegas da escola Dr. Vital Fogaça de Almeida que me socorreram nos momentos difíceis.

À Beatriz Coelho, por indicar caminhos que me pareciam inexistentes.

Aos membros de minha banca de qualificação: Profa. Dra. Elisabeth Azevedo e Profa. Dra. Telê Ancona Lopes, pelos comentários e observações a respeito da pesquisa. À Profa Telê agradeço também por me ajudar com os estudos sobre Mário de Andrade.

À Secretaria de Educação do Estado de São Paulo pela concessão da bolsa-mestrado, e aos funcionários da Diretoria de ensino Leste 1.

Mais uma vez ofereço meus sinceros agradecimentos. 
Resumo: O objetivo deste trabalho é apresentar um estudo, de cunho histórico e crítico, sobre o teatro brasileiro, a partir de pesquisa realizada nos periódicos da cidade de São Paulo do período de 1901 a 1922. Com base nos dados colhidos, como notícias e críticas de teatro, buscou-se analisar a atividade teatral desse início de século, e repensar suas contribuições, seu papel social, e aparente estagnação - tão divulgada por intelectuais à época. O estudo interpretativo encontra-se no volume I. No volume II há um índice dos periódicos consultados, contendo uma síntese dos temas relativos ao teatro, abordados por escritores e intelectuais desse período.

Palavras-chave: Teatro brasileiro, periódicos paulistas, teatro de revista, opereta, Mário de Andrade.

Abstract: The objective of this work is to present a study, of historical and critical matrix, on the Brazilian theater, from inquiry carried out in the magazines of the city of Sao Paulo. On basis of the gathered data, like news and criticism of theater, it was carry out analyze of the theatrical activity of this beginning of century, and rethought its contributions, social paper, and apparent stagnation - so spread by intellectuals. The interpretative study is presented in the volume I. In the volume II there is a rate of the consulted magazines, containing a synthesis of the relative subjects to the theater, boarded by writers and intellectuals of this period. 


\section{Sumário}

\section{Introdução}

\section{Capítulo I}

A "decadência" do teatro brasileiro no início do século XX 13

1.1. O triunfo da opereta 16

1.2 A ascensão das revistas $\quad 35$

1.3 Espetáculos de Variedades $\quad 55$

1.4. A presença estrangeira 63

1.5 A prosódia lusitana 82

$\begin{array}{ll}1.6 \text { O Cinematógrafo } & 89\end{array}$

\section{Capítulo II}

$\begin{array}{ll}\text { A valorização do teatro nacional } & 93\end{array}$

2.1. A cidade de São Paulo como cidade das artes e do teatro 94

2.2. As companhias nacionais e paulistas 98

2.2.1 A Companhia Arruda $\quad 99$

2.2.2 A Companhia Dramática Paulista 108

2.2.3 Itália Fausta 114

$\begin{array}{lr}\text { 2.2.4 Leopoldo Fróis } & 119\end{array}$

2.3. A evolução do teatro considerado sério $\quad 124$

2.3.1. Cláudio de Souza: Flores de Sombra 128

2.3.2. Mon Coeur balance e Lêur Ame: Guilherme de Almeida e Oswald de 135 Andrade

2.3.3. Importantes representações destacadas nas páginas da imprensa: Eva, de João do Rio; O Contratador de Diamantes, de Afonso Arinos

\section{Capítulo III}

Mário de Andrade: um dramaturgo no pré-modernismo 151

$\begin{array}{ll}\text { Conclusão } & 173\end{array}$

$\begin{array}{lr}\text { Bibliografia } & 176\end{array}$ 


\section{Introdução}

Estudiosos do teatro brasileiro do século $X X$, valorizando-o a partir da encenação de Vestido de Noiva, de Nelson Rodrigues, relegam a segundo plano a produção teatral do início desse século. Essa produção, no entanto, considerada menos importante, contribuiu para a nossa arte teatral e para a formação de uma sociedade com características próprias e bem definidas.

Com o intuito de repensar o teatro brasileiro do início do século $\mathrm{XX}$, suas contribuições, seu papel social, e sua aparente estagnação - tão divulgada por intelectuais à época - propusemo-nos a pesquisar os periódicos de São Paulo de 1901 a 1922. Esse recorte foi decidido por acreditarmos já não ser mais possível traçar um panorama do teatro brasileiro deixando uma lacuna nesses anos iniciais. Ademais, tudo o que foi produzido antes de 1922 permanece à margem da história, desprezado e desmerecido. Logo, achamos justo dar o devido reconhecimento aos artistas, dramaturgos e empresários atuantes nesse período.

A opção por trabalhar com fontes primárias justifica-se por exercerem um papel importante como suporte documental da história, e do modo de vida de grupos sociais em determinado período. Além disso, resgatam, do passado, testemunhos vivenciados no presente. Contudo, deve-se atentar a esses testemunhos. Escritos "no calor da hora", eles podem ser tendenciosos e manipuladores. A visão "de fora", distante, porém, socorre o pesquisador.

Apesar de a cidade paulistana ter presenciado um período fértil para a imprensa periódica nos anos em estudo, motivado pelo seu desenvolvimento urbano, enfrentamos dificuldades para localizar esse material. Um estudo eficiente dos periódicos paulistas, fundamental para a realização de nossa pesquisa, encontra-se em São Paulo em Revista: Catálogo de Publicações da Imprensa Cultural e de Variedades Paulistana, 1870-1930, de Heloísa Faria Cruz. A pesquisadora realizou um levantamento dos periódicos publicados entre os anos de 1870 e 1930 e indicou onde encontrá-los.

O acesso a essa documentação, no entanto, representou outro obstáculo a ser enfrentado. Embora Arquivos e Bibliotecas trabalhem com a preservação desse 
material, muitos se encontravam indisponíveis para consulta, ou com séries incompletas e fragmentadas. Assim, sentimos a necessidade de ampliar nosso campo de atuação. Se no primeiro momento restringimos a pesquisa às revistas literárias, passamos depois a considerar periódicos de diferentes vertentes de atuação, tais como almanaques, revistas humorísticas, de variedades e recreativas.

Quanto às informações técnicas de cada periódico, muitos não apresentavam número, mês e página. Referente à ortografia vigente nos textos, esta seguiu a ortografia contemporânea, exceto nas passagens marcadas por sic.

O estudo sobre o teatro brasileiro de 1901 a 1922 foi realizado a partir de um levantamento de artigos críticos, textos teóricos e notícias de eventos teatrais. Em suma, textos sobre teatro publicados nos periódicos da época.

O teatro de revista e a opereta nessa época prevaleciam sobre o teatro considerado sério e literário. No entanto, aqueles gêneros, classificados como ligeiro e musicado, foram os responsáveis por manter vivo o teatro brasileiro em um período de predomínio de companhias teatrais estrangeiras e também de forte influência das idéias e culturas vindas de fora para o nosso país.

Nesta fase do teatro a que comumente está associada a idéia da "decadência do teatro brasileiro" também encontramos tentativas de "cunho literário", tais como As Flores de Sombra, de Cláudio de Souza, ou as peças em francês de Oswald de Andrade e Guilherme de Almeida, além de incursões inéditas de Mário de Andrade na seara do teatro. Portanto, dizer que não houve teatro nacional nesse momento talvez seja um pouco precipitado.

Estudos já realizados por pesquisadores, como Miroel Silveira e Neyde Veneziano, confirmam a existência e a atividade do teatro nacional no início do século XX, uma vez que o teatro de revista seria uma manifestação que contribuiu e muito para a nossa formação cultural, retratando e criticando nossos costumes; crítica essa, aliás, que ia do campo social ao político. Além disso, Tiago de Melo Gomes desmistifica a tão propagada idéia de que esses gêneros teatrais só atraíam as massas. Pesquisando os arquivos da empresa Paschoal Segreto, fica 
comprovado que o público desses espetáculos não se limitava ao povo, mas abrangia também a elite, que pagava caro por um bom lugar no teatro'.

Os críticos e intelectuais atuantes na imprensa da época lamentavam nas páginas das revistas literárias que o teatro deveria representar o seu povo, e, no entanto, o preconceito não Ihes permitia ver características inerentes às nossas raízes no teatro musicado.

Outro dado importante, muito mencionado nas fontes pesquisadas, é a presença constante de companhias estrangeiras nos nossos palcos. Essa situação não proporcionava aos nossos artistas mais destaque na cena teatral. No entanto, há que se considerar o lado positivo dessa presença estrangeira, posto que esse contato favoreceu, apesar de tudo, a formação de um teatro efetivamente brasileiro, através de uma relação antropofágica, antes mesmo que esse conceito viesse a ser discutido.

A ascendência do cinematógrafo, a falta de subvenção oficial e de bons atores e autores também são temas das discussões trazidas pelos periódicos. Assim como as referências a São Paulo como a capital artística do país, reveladoras do desejo de deslocar os holofotes do Rio de Janeiro e apontá-los em outra direção. Isso se evidencia a partir de 1914, quando se organiza um forte movimento dos intelectuais, encabeçado por Monteiro Lobato e a sua Revista do Brasil, de transformar São Paulo na capital cultural do país.

É preciso ressaltar que o campo de pesquisa limitou-se às revistas da época. Todavia, foi encontrado um importante artigo no jornal O Furão, o qual encontra-se na Biblioteca Nacional, que achamos justo incorporar ao material colhido, assim como uma peça de Arlindo Leal, no Arquivo Ilustrado, de 1899.

Tentaremos, na medida do possível, seguir uma ordem cronológica dos fatos e acontecimentos, para verificar o processo de evolução das idéias teatrais em São Paulo. Contudo, a dificuldade de acesso ao material de pesquisa acabou por deixar lacunas de alguns anos no nosso trabalho, o que não compromete a análise do todo. O objetivo é apresentar como os periódicos retratavam a arte

1 GOMES, Tiago de Melo. Um Espelho no palco: Identidades Culturais e Massificação da Cultura no Teatro de Revista dos anos 1920. Campinas, Ed. da Unicamp, 2004. 
teatral no país, particularmente em São Paulo, o que era notícia, o que era ou não valorizado, e as principais idéias e reflexões acerca do teatro, pois, como já informamos, acreditamos que as pesquisas nas fontes primárias são de grande valia para a reconstituição dos valores de determinadas épocas e lugares.

Todo o material coletado foi organizado em um índice de artigos sobre o teatro brasileiro do período de 1901 a 1922, com breves resumos a respeito de seu conteúdo e natureza. Esse índice baseou-se no trabalho desenvolvido por José Aderaldo Castello juntamente com seus orientandos de mestrado e doutorado ${ }^{2}$. 0 projeto consistia em estudar uma revista pré-modernista, ou modernista, e refletir sobre seu contexto de produção, literário e cultural. Em seguida, havia um índice detalhado referente ao conteúdo de cada número da revista selecionada. Apoiando-nos nesse modelo, fizemos um índice das publicações sobre teatro encontradas nas revistas desses anos.

A partir disso, elaboramos um estudo de cunho histórico e interpretativo sobre o teatro em São Paulo no início do século $X X$, no período que se convencionou chamar de pré-modernista.

A pesquisa realizou-se nos seguintes acervos: Biblioteca Central da Faculdade de Filosofia, Letras e Ciências Humanas; Biblioteca do Instituto de Estudos Brasileiros; Biblioteca da Escola de Comunicação e Artes, todas pertencentes à Universidade de São Paulo; Biblioteca Municipal Mário de Andrade, em São Paulo; Arquivo do Estado de São Paulo; e na Fundação Biblioteca Nacional, no Rio de Janeiro. Foram consultados os seguintes periódicos:

1- Álbum Imperial

2- $\quad$ Almanaque de Casa Branca

3- $\quad$ Almanaque do Estado de São Paulo

4- $\quad$ Almanaque de Franca

5- $\quad$ Almanaque histórico-literário do Estado de São Paulo

6- $\quad$ Almanaque llustrado de São Paulo

7- $\quad$ Almanaque Melillo

2 CASTELLO, José Aderaldo. "A Pesquisa de periódicos na Literatura Brasileira". In; NAPOLI, Roselis Oliveira de. Lanterna Verde e o Modernismo. São Paulo: IEB/USP, 1970. 
8- $\quad$ Almanaque d'oeste do Estado de São Paulo

9- $\quad$ Almanaque Paulistano

10- Almanaque Paulista llustrado

11- Arquivo llustrado

12- A Cigarra

13- Correio Musical Brasileiro

14- O Echo

15- Éden/ Revista Theatral e Cinematográfica

16- Gazeta Artística

17- Ilustração Paulista

18- Íris

19- Klaxon

20- O Monóculo

21- A Novella Semanal

22- O Palco llustrado

23- Papel e Tinta

24- A Paulicéia Moderna

25- O Pirralho

26- O Queixoso

27- Revista do Brasil

28- Revista Feminina

29- Revista Nacional

30- Revista Santa Cruz

31- Revista Teatral/ Teatro, Sport, Arte e...o que for

32- Revistinha

33- A Ronda

34- $\quad$ A Vida Moderna

35- Vida Paulista

Alguns números das revistas não traziam informações sobre teatro. No entanto, achamos importante mencioná-los no índice, contendo essa observação, a fim de poupar o trabalho de outros pesquisadores. Nosso índice ficou organizado da seguinte forma: 
1. Peças de teatro, homenagens à classe teatral: poemas e dedicatórias, escritos diversos de autores consagrados

\section{Noticiário}

2.1. Notícias e Notas (informações gerais sobre a vida teatral)

3. Crítica Teatral (opinião dos intelectuais, críticos, jornalistas em relação ao teatro produzido na época)

3.1. Sobre a "decadência" do teatro nacional, peça teatrais, o trabalho de atores, dramaturgos, diretores

4. Entrevistas, enquetes

5. Fotos e charges

O primeiro item registra as peças teatrais ou esquetes publicados nos periódicos; também achamos relevante registrar poemas, contos e crônicas escritos por autores consagrados, como Artur Azevedo e Mário de Andrade. O segundo constitui-se do noticiário em geral: notas, anúncios, sátiras, divulgação, comentários sobre as peças em cartaz e o meio teatral. No terceiro tópico encontram-se artigos opinativos e, inclusive, debates travados entre intelectuais e revistas sobre a situação do teatro nacional. As entrevistas e enquetes realizadas com pessoas pertencentes à vida teatral estão no item quatro. No último tópico registram-se as fotos dos artistas e dos teatrólogos; e charges, referentes ao teatro. A ordem de apresentação dos periódicos segue a numeração da listagem anterior. Tentamos desenvolver esse índice da forma mais simplificada possível, para que seja um material de fácil consulta.

Convém destacar que há muitos periódicos ainda a serem pesquisados. Mas enquanto não estiverem disponíveis aos pesquisadores, estarão guardando preciosas informações. Além disso, lamentamos o fato de muitas coleções estarem incompletas.

Para maiores informações sobre as revistas recomendamos o livro de Heloísa Faria Cruz citado. Nele encontra-se o ano de publicação da revista; 
características técnicas, tais como periodicidade, formato, número de páginas e colunas; proprietário; conteúdo; e os acervos onde encontrá-las. Lembramos novamente que nem todos os acervos estão abertos ao público, como o Instituto Histórico e Geográfico, por exemplo, com o qual tentamos contato desde 2001, sem sucesso. 


\section{Capítulo I}

\section{A decadência do teatro brasileiro}

Em 1865, estreou no Brasil a opereta francesa Orphée aux Enfers, música de Offenbach e texto de Hector Crémieux e Ludovic Halévy. O sucesso do espetáculo foi tão grande que em pouco tempo esse tipo de peça tornou-se o protagonista na cena teatral brasileira. A estrutura desse gênero valoriza a música, a comicidade, a dança e a sensualidade, em detrimento do texto. A partir de então, as comédias realistas que faziam sucesso no Ginásio Dramático foram, paulatinamente, substituídas pelo teatro musicado e ligeiro no gosto popular, que reinou absoluto nos nossos palcos.

É importante fazer essa retrospectiva para entender que a expressão "decadência do teatro brasileiro" surgiu no momento em que a opereta e o teatro de revista se fortaleceram na cena teatral. A partir disso, cronistas, intelectuais e escritores conceituados passaram a redigir seus textos e colunas afirmando a crença nessa fase "decadente", em que as peças de cunho literário, do chamado teatro sério, eram preteridas pelo público e pelos dramaturgos que se voltavam ao teatro musicado.

Por mais de 50 anos, a palavra "decadência" será usada para se referir ao teatro brasileiro. Um dos primeiros textos é o bastante conhecido "Instinto de Nacionalidade", de Machado de Assis, que data de 1873. O artigo, encomendado por José Carlos Rodrigues, editor do periódico O Novo Mundo, editado em Nova lorque, traz uma reflexão acerca da nossa formação literária e, ao abordar o teatro, Machado mostra-se severo e pessimista.

Não há atualmente teatro brasileiro, nenhuma peça nacional se escreve, raríssima peça nacional se representa. As cenas teatrais deste país viveram sempre de traduções, o que não quer dizer que não admitissem alguma obra nacional quando aparecia. Hoje, que o gosto público tocou o último grau da decadência (grifo nosso) 
e perversão, nenhuma esperança teria quem se sentisse com vocação para compor obras de severa arte. ${ }^{3}$

Após esse, outros seguirão. Nos periódicos pesquisados, textos desta natureza aparecem de 1905 até 1920.

Para os intelectuais, o papel primordial do teatro deveria ser educar as platéias, passar valores morais e edificantes. Assim sendo, o teatro de revista e a opereta não serviam de paradigma, pois seu único intuito era o de fazer rir. E como atingiram plenamente seu intuito, esses gêneros foram responsabilizados por aquilo que se convencionou chamar de a "decadência do teatro brasileiro".

Além da ascensão do teatro musicado, a imprensa imputou a outros setores a responsabilidade por essa decadência. A presença constante de companhias estrangeiras em solo brasileiro, a falta de companhias e de autores nacionais, os números de variedades, o cinematógrafo, e até a prosódia portuguesa estão entre os agentes causadores dessa má fase.

Nas páginas da Revista do Brasil, encontra-se um ensaio sobre a história do teatro brasileiro. Escrito em 1922, em meio às comemorações do Centenário da Independência, o texto recebeu o seguinte título: "Cem anos de Teatro". O resultado final, entretanto, foi um breve histórico do teatro no Brasil. Aproveitando a divisão de períodos feita por Sílvio Romero, Otávio Quintiliano comenta, em poucas palavras, a situação do teatro desde Anchieta até o momento em que o teatro entrara em crise, segundo a voz ecoante na época. Após a República, essa crise teria se acentuado e o teatro entrara em franca decadência. Com ares de reprovação, o crítico lamenta:

Essa decadência-é doloroso dizer, mas é absolutamente verdadeiro,- assenta ainda hoje em três causas principais: na quase ignorância que, salvo exceções honrosas, campeia no nosso meio artístico; no mercantilismo das empresas teatrais e na incompetência ou insinceridade da quase maioria da crítica.

Em um tal período "o teatro brasileiro ficou mais escuro...

3 ASSIS, Machado “Instinto de Nacionalidade». In: FARIA, João Roberto. Idéias Teatrais: o século XIX no Brasil. São Paulo, Perspectiva: FAPESP, 2001 
E a treva cresceu...

E a luz apagou-se..." 4

Tratemos, portanto, de acendê-la, a fim de propor uma releitura da cena teatral brasileira do início do século XX.

4 Revista do Brasil, número 82, outubro de 1922, Ano VII, Volume XXI, pp. 181 a 186. 


\subsection{O triunfo da Opereta}

Quando no regime da opereta offenbachiana descambou em França a arte do teatro, o mesmo inevitavelmente sucedeu entre nós. Na antiga rua da Valla (que hoje alargada se chama de Uruguaiana) houve uma casa de espetáculos denominada o Alcazar. Ali cintilaram estrelas, cujo maior brilho não era o da arte pura. O Alcazar, freqüentado pela mocidade livre e pela velhice patusca, fez a mais rude concorrência ao teatro sério. Offenbach fazia dançar a França e com ela o mundo inteiro. O Rio, e com ele o Brasil, entraram na roda. Não foi a primeira nem a última tolice a que nos induziu a sedutora cabeça da raça latina. ${ }^{5}$

A opinião do jornalista Carlos de Laet faz eco à opinião vigente, na época, de que o teatro brasileiro entrara em um período decadente após sofrer influências das operetas francesas, tendo como precursora dessa fase Orphée aux Enfers, de Offenbach. Mário Nunes, em seu livro 40 anos de teatro, compartilha da opinião de que o início da decadência do teatro se dá com o surgimento de Offenbach. ${ }^{6}$

Para os não conhecedores do idioma francês, as operetas francesas traziam um inconveniente. Portanto, logo surgiram as traduções e as paródias das operetas. A primeira a surgir foi Orfeu na Roça, do ator Vasques, em 1868, e abriu caminho para outros autores, inclusive Artur Azevedo, que escreveu $A$ Filha de Maria Angu, versão de La Fille de Mme. Angot, e Abel, Helena, paródia de La Belle Helène, entre outras.

Sobre o Orfeu na Roça, escreveu Carlos de Laet:

Quando o Vasques, disfarçado em galo, se exibiu lá em uma cena do Orpheu, toda a platéia, escangalhando-se em riso, consagrou o início da pachuchada. Entrou o teatro em um período letárgico...E ainda está dormindo. ${ }^{7}$

5 Revista do Brasil, janeiro de 1918, número 25, ano III, Vol. VII, pp. 98 e 99. 6 NUNES, Mário. 40 anos de teatro, Rio de Janeiro: SNT, 1956, vol. 1, p.33.

7 Revista do Brasil, número citado. 
Essas foram as primeiras manifestações de um gênero que encantaria 0 público, mas enfastiaria a crítica, e cuja permanência seria longa nos palcos, como comprovam as citações acima, ambas da Revista do Brasil, de 1918.

Neyde Veneziano assim define a opereta:

Misto de comédia e melodrama, o qual era sempre levado na brincadeira, entremeada de números musicais (que iam da valsa ao can-can, evidentemente) a opereta referia-se, também, a assuntos do cotidiano imediato. Sob uma aparente aura sentimental (nesse caso é evidente a diferença com a revista), ela poderia ser também ferina, crítica, mordaz. Mas o amor era o seu tema central e o allegro-vivace, o seu andamento. ${ }^{8}$

Um artigo de 1908 do periódico Vida Paulista, dirigido por Arlindo Leal, discute a origem da opereta. Segundo seu autor -não identificado- o inventor desse gênero foi Hervé, autor de Oeil Crevé, do Chilpèric, do Petit Faust, e Dom Quixote e Sancho Pança (representada num teatro de Montmartre). A opereta pioneira chamava-se $O$ Urso e o Pachá, e foi representada em um sanatório para pessoas com insanidade mental, localizado em Bicêtre, onde Hervé trabalhava como organista.

Conforme o artigo, a peça foi representada e cantada pelos loucos do hospital. Tudo começou após um passeio ao local, quando o autor se impressionou com o talento e a capacidade musical dos internos e se propôs a ensinar-lhes música. Mas, não contente em ensinar somente música, Hervé pede autorização ao diretor do hospital para que os pacientes possam representar uma comédia. Surpreso e espantado com a notícia, o diretor é tranqüilizado pelos internos que afirmam já terem sido escolhidos os atores, a peça e a música.

A opereta selecionada, O Urso e o Pachá, é caracterizada como um engraçado vaudeville de Scribe e Sanitine, já representado em outra ocasião nas Variétés, em 1820. As árias, no entanto, seriam substituídas pelas escritas por Hervé. Como se percebe, opereta e vaudeville aparecem no artigo como 
sinônimos. Por terem a música como elemento comum, os gêneros musicados, muitas vezes, não eram diferenciados. Podia ocorrer de uma Companhia chamar uma peça de opereta, a outra, de revista, ou ainda de vaudeville.

Patrice Pavis esclarece que do século XV ao XVIII o vaudeville era um espetáculo que mesclava canto, dança, acrobacias e monólogos. A partir do século XIX, Scribe, Labiche e Feydeau alteraram as feições do vaudeville, que passou a ser uma comédia de intriga, ligeira e sem pretensão intelectual ${ }^{9}$.

No dia 15 de março de 1842 teria subido à cena no hospital de Bicêtre $O$ Urso e o Pachá. Tudo transcorrera tranqüilamente, sem nenhum incidente que prejudicasse a estréia, a não ser pelo interno Tachot, que tinha a idéia fixa de que deveria ir embora, pois sua família o esperava. No final da peça, quando todos foram chamados para os aplausos, Tachot avançou na cena, dizendo:

"O meu embrulho! Onde é a saída? A minha família espera-me!"

Mas foi sossegado com um torrão de açúcar.

Essa, segundo o articulista, teria sido a primeira opereta de fato, pois "certas óperas-cômicas bufas, como o Rendez-vous bourgeois, o Tableau parlant, o Irato e outras muitas não podem ser consideradas operetas ao pé dos atos burlescos de Hervé ou das obras fantasistas de Offenbach e de Charles Lecocq".

Apesar de ter perdido um pouco de espaço para o Teatro de Revista, no segundo decênio do século $X X$, a opereta continuava a ser assunto nos periódicos. Um artigo publicado em $A$ Vida Moderna, na edição de 15/01/1920, questionava em seu título: "O que é a opereta?'. Para esclarecer essa questão, o jornalista recorreu ao passado. Em 1856, alguns críticos após assistirem a estréia de $A$ Bela Helena consideraram a opereta uma caricatura musical.

Múcio da Paixão, embebido da cultura francesa, expõe a sua definição de opereta:

9 PAVIS, Patrice. Dicionário de Teatro. São Paulo: Perspectiva, 1999, p. 427. 
Criação genuinamente parisiense, é, por isso mesmo, cheia de alegria, de bom humor, de graça, de espírito, sendo petulante, maliciosa, galhofeira, com o fim de desanuviar os mais taciturnos semblantes, as fisionomias mais melancólicas. ${ }^{10}$

O historiador considerava um exagero atribuir a decadência do teatro brasileiro à opereta, pois para isso seria necessário admitir que o gênero alegre é incompatível com a arte; e a tristeza, a sua condição primordial.

São poucos os textos publicados nos periódicos que adotam uma postura favorável às operetas. Na Ilustração Paulista de julho de 1912, encontramos um:

E que há muito quem prefira cançonetas e excentricidades ao que de bom nos possam oferecer as operetas, os dramas e as comédias.

Normalmente as operetas apareciam em oposição aos dramas e comédias, reforçando a antítese teatro ligeiro e teatro literário, ou teatro que abastarda os homens e teatro que os enobrece.

Apesar do incômodo causado aos críticos, o público apreciava o gênero musicado, e corria aos teatros para apreciar os espetáculos. É possível confirmar tal afirmação, observando as colunas teatrais nos periódicos.

Arlindo Leal, crítico, dramaturgo e jornalista, respondia pelas críticas teatrais da revista campineira Íris, nos anos de 1905 e 1906. Em uma delas, de 1906, o jornalista reclamava que a situação no teatro não se transformara desde 1897 , quando ele incentivara a iniciativa de alguns escritores de educar o gosto do público e não se render a ele. Como conseqüência dessa imutabilidade, a cena adquirira o caráter de uma "escola perniciosa", encenando peças que não levavam em conta a moral e os bons costumes.

A responsabilidade por essa situação, conforme Arlindo Leal, era de todos que "mercadejam a arte". Nessa categoria incluíam-se os empresários, que desprezavam as produções consideradas sérias, a fim de garantir seu lucro, sem se importarem com a educação do público; e os escritores, que sonhavam com 
sucesso e renome, sem cuidar do manejo literário, preferindo o "efeito cenográfico e pornográfico".

O crítico, indignado com a situação, bradava que os escritores teatrais atentavam contra o decoro público e se esqueciam de que "o teatro se fez para a educação de um povo" - expressão proferida diversas vezes por Arlindo Leal em seus textos. Baseando-se ainda nas idéias do teatro realista, considerava digno de aplausos o dramaturgo que privilegiasse o estudo do meio, a análise de um caráter, e criticasse usos e costumes. Diferente disso, o teatro não podia ser compreendido, pois só assim o espectador poderia refletir e corrigir seus costumes.

Contrário aos seus desejos, as atenções no momento se voltavam ao teatro musicado, inclusive a opereta. Sua opinião a respeito desse gênero era severa:

Além do gênero revista (em que o autor deste artigo também cometeu o seu pecado), as comédias que ora são levadas à luz da ribalta ressentem-se do mesmo vício, do mesmo contágio. Ferem o ouvido dos assistentes com frases de baixo calão, o jogo de espírito é substituído por trocadilhos chulos; as frases veladas ou ambíguas desaparecem, surgindo os apartes livres, em conjunto com a exibição, aparatosa e ridícula, a um tempo, de verdadeiros quadros vivos! $!^{11}$

A influência de autores como Hennequim, Alexandre Bisson e George Feydeau teria sido danosa ao teatro. A encenação de produções francesas, como Hotel do Livre Câmbio, Paraíso e Lagartixa, desprezava o modelo considerado de bom gosto, e valorizava as composições de moral duvidosa.

Múcio da Paixão, em $O$ teatro no Brasil, faz uma exaltação ao gênero ${ }^{12}$. 0 autor considerou que, mesmo apresentando cenas desrespeitosas, a opereta não deixava de ser alegre e de ter uma missão civilizadora, uma vez que se propunha a levar "graça esfuziante" aos espíritos, em oposição a uma "seriedade hipócrita e ridícula". Apesar do otimismo, esse se mostrou um momento isolado, pois, posteriormente, ele retoma a idéia consensual de que havia outras formas de arte superiores à opereta, e que o espírito humano não necessitava só de grandes

11 Íris, Vol. I, 1906

12 PAIXÃO, Múcio. Op. cit. p. 226. 
emoções, mas também de distrações que exigissem uma menor tensão intelectual e menos concentração.

Os intelectuais demonstravam urgência em achar os responsáveis pela "decadência do teatro brasileiro". Uns acusavam os empresários, outros, os dramaturgos, e a maioria responsabilizava o público.

A preferência do público pela opereta é tema de dois artigos do professor e crítico Antonio Piccarolo publicados na Gazeta Artística. Em ambos, Piccarolo discorreu sobre o tema utilizando-se de um tom irônico e preconceituoso, com o qual acusava o público de ser responsável por fazer prosperar um gênero que, segundo ele, era "medíocre".

No primeiro, intitulado "Ressurgimento da opereta"13, afirmava não ter a intenção de "endireitar as pernas...do público freqüentador dos teatros", pois essa atitude não the modificaria o gosto. Desse modo, o professor desenvolveu seu texto com o intuito de provar que o sucesso da opereta resultava do despreparo do público para apreciar os espetáculos de verdadeira arte. Justificava-se argumentando que as condições sociais da época não propiciavam a formação de um público de bom gosto. A única platéia possível seria constituída de pessoas que "empregavam o dia no trabalho exaustivo", e que, após uma jornada de obrigações, sentia a necessidade de se divertir, "sem obrigar o cérebro a um trabalho penoso de elaboração". Essa era a opinião do crítico: o público, formado por pessoas do povo, executava serviços úteis e necessários à sociedade, mas não possuía uma "inteligência superior" que lhe permitisse apreciar o bom teatro, limitado no artigo ao teatro lírico. Essa visão, aliás, parece ser corrente entre os intelectuais, pois se aproxima muito da opinião de Fialho de Almeida transcrita por Múcio da Paixão:

Dar a um tal público comédias preciosas, literaturas de requinte, dramas de sentimento e lacrimejo, é obrigar a pensar esses cérebros vegetativos cuja fadiga é já grande, à noite, por todo um dia de trabalho. Certo tipo de espectador é incapaz de

13 Gazeta Artística, número 2, 24/12/1909, ano I. 
um prazer de pura arte... Não compreenderá as finuras de frase, a sutileza das análises psicológicas, a audácia de certas ironias e de certos paradoxos. ${ }^{14}$

Não sabemos como foi a recepção do público às críticas publicadas na Gazeta Artística, mas no seu segundo artigo, divulgado alguns meses depois, Piccarolo apresenta-se um pouco mais brando, apesar de não abandonar a ironia e o preconceito. Dessa vez, o articulista aprofunda a tese de que cada povo tem a arte que merece, mote com o qual encerrara o texto anterior. A arte, segundo propagava, assemelhava-se a um espelho, ou seja, refletia a sociedade à qual pertencia. Continuando esse raciocínio, afirmava, portanto, que a opereta era a forma artística que melhor representava a sociedade da época, já que possuía a força de levar o mais numeroso público ao teatro. Sua opinião a respeito do público, porém, não havia se alterado tanto, apesar do tom mais ameno:

Significa isto que o público não é dotado de um gosto fino, de um gosto superior em matéria de música? Pode ser...antes é a pura verdade. E por isso mesmo que é um fato não se presta a discussões. ${ }^{15}$

Antonio Piccarolo, ciente da necessidade de ampliar o repertório musical do público, visava à preparação de uma escola voltada para esse fim. Sua estratégia direcionava-se à "educação" do gosto musical das pessoas, através de um processo lento de substituição da música de opereta, de Suppée e Strauss, pela música clássica, de Wagner e Verdi. A opereta seria a alavanca desse projeto, uma vez que agradava o público.

A música banal vai se tornando aristocrática mesmo na forma ligeira; porque, praticamente, não é somente a música heróica, e a música clássica que merecem o nome de fina e aristocrática. ${ }^{16}$

14 PAIXÃO, Múcio. Op. cit. p. 570.

15 Gazeta Artística, número $10,1^{\circ} \mathrm{e} 2^{\circ}$ quinzena de Maio de 1910 , ano I

16 Idem, ibidem. 
Como dito anteriormente, não é possível saber o teor dos comentários provocados pela leitura do primeiro artigo, de dezembro de 1909, mas podemos supor que as críticas não foram bem aceitas, pois no texto seguinte, "Voltando ao tema", o crítico abaixa bem o seu tom ferino e rude. Além disso, tece comparações entre algumas produções de operetas e as óperas bufas italianas, cujos assuntos tornaram-se, com o tempo, "menos desalinhados e menos vulgares", tais e quais os da sucessora brasileira. O que antes se assemelhava a uma "pachuchada de gente de viela", pela frivolidade ou pela ausência de assunto, tivera um progresso.

O artigo finaliza com elogios à apresentação da opereta Sangue de artista:

É um drama, um forte drama até a comoção, que se desenvolve sob as vistas do espectador. O final do primeiro ato, por exemplo, é de um efeito dramático surpreendente, digno de ser admitido entre os mais notáveis momentos artísticos da arte dramática. (...) Que importa se aqui ou acolá apareça uma cena alegre ou se mostra alguma ponta de humorismo? Não é, talvez, esta também a arte dos maiores autores dramáticos?

Que significa tudo isto? Vem provar que a opereta se avia para formas novas ou volta ao passado, à clássica ópera bufa, que possui verdadeiras obras-primas. Tal fato se deve sinceramente desejar pela ação que este gênero de teatro exerce hoje sobre as classes médias, que são as mais assíduas freqüentadoras do teatro, servindo para a educação de seu senso estético. ${ }^{17}$

Essa opereta recebera elogios da imprensa quando representada, anos antes, em 1911.

Todos os freqüentadores do teatro sabem que Sangue d'artista é uma das mais deliciosas operetas que ultimamente se tem cantado entre nós, e é pela sobriedade com que foi composto o libreto, sem liberdades condenáveis, sem falsas situações, mas equilibrado e brilhante. ${ }^{18}$

17 Idem, ibidem.

18 Ilustração Paulista, número 11, 16/03/1911, Ano I. 
A suposta crise enfrentada pelo teatro incomodava tanto aos críticos que eles se viram obrigados a buscar uma identificação com o teatro realizado em outros países, a fim de amenizar seus ânimos.

Alfred Capus analisou a situação do teatro francês no pós-guerra, em artigo transcrito na Revista do Brasil ${ }^{19}$. Segundo observou, a sociedade, nesse momento, encontrava-se "mais agitada no fundo do que na superfície" e os sentimentos, idéias e regras de conduta passariam por transformações. Em relação ao teatro, esse processo resultaria em um público ávido por distrações, preferindo, portanto, espetáculos variados, fáceis e de qualidade inferior, os quais mesclariam "combinações bizarras de cinema, de circo e de arte dramática, dado que isso ainda se possa chamar de arte dramática". A isso se juntariam autores e artistas que, obrigados pelas circunstâncias, tornar-se-iam medíocres, e o lado industrial do teatro prosperaria, atingindo elevado grau de vulgaridade. Quanto ao público, o autor apostava em mudanças, como a redução do número de espectadores, os quais instruídos pelas lições da guerra saberiam valorizar a verdadeira arte. Esse público menos vultoso seria formado pela elite francesa, enquanto o grande público, subtendido como sendo o povo, voltaria-se para as produções de qualidade considerada inferior.

Essa visão aproxima-se bastante da expressa anos antes por Piccarolo.

Um público cansado da luta pela vida quer uma arte, que o divirta e the proporcione algum repouso às fadigas diárias.

Um público sossegado, tranqüilo, sem as preocupações materiais da existência, procura a arte que o eleve, que o faça pensar. ${ }^{20}$

A crise do teatro português também é retratada pela Revista do Brasil. Júlio Dantas, dramaturgo conhecido por A Ceia dos Cardeais, refletiu sobre as causas dessa crise, e concluiu se tratar do despreparo dos atores e de falta de disciplina.

19 Revista do Brasil, número 18, ano II, vol. V, junho de 1917, pp.262-263. Esse ensaio foi publicado pela Revista do Brasil em 1918, mas não sabemos em que ano foi originalmente publicado na revista francesa Hebdomadaire. 
Todavia, a maior responsável era mesmo a "indústria no teatro", uma séria ameaça à "indústria do teatro" (grifo nosso) ${ }^{21}$.

O periódico Éden revista / Revista Theatral e Cinematográfica relatou que a decadência no teatro acentuara-se cada vez mais até a chegada ao momento atual em que ele estava morto definitivamente. Havia dois anos a organização de uma Companhia do Municipal trouxera expectativas de um renascimento do teatro brasileiro. O grupo alcançara grande sucesso no Rio de Janeiro, principalmente com a representação de $A$ Bela Madame Vargas, mas não conseguira subvenção oficial para excursionar a São Paulo e dissolvera-se. Desde então, conforme o ensaio, nada mais acontecera em termos de teatro nacional, que pudesse ser considerado arte. Além disso, as platéias não cooperavam com o renascimento do teatro, pois, viciadas pela opereta, preferiam assistir à Viúva Alegre, O Conde de Luxemburgo a uma peça de Júlia Lopes ou Guanabarino, e abandonavam a arte nacional ${ }^{22}$.

As críticas à opereta eram tão severas porque se baseavam na justificativa de que esse tipo de teatro não servia para educar o público. $O$ conceito de que 0 teatro deveria ser uma escola de moral e de bons costumes era inquestionável.

Arlindo Leal manifestou-se sobre o assunto:

O teatro, diz notável escritor, eleva e civiliza a multidão que o freqüenta; a arte dramática foi criada para o povo, e é ao povo que ela se dirige para vivificar sua existência moral, revelando-lhe faculdades que ele possui, mas ignora. ${ }^{23}$

É evidente neste excerto o parecer do crítico. Ele defende que as peças deveriam apregoar bons valores para, desse modo, influir na educação do povo. Esse seu ponto de vista rendeu assunto para dois artigos, ambos publicados na revista Íris, em $1906^{24}$.

21 Revista do Brasil, número 29, ano III, vol. VIII, maio de 1918, pp.99-100.

22 Éden revista/ Revista Theatral e Cinematográfica, número 12, março de 1915, ano III.

23 Íris, 1906.

24 Íris, Vol I, 1906. Excetuando-se a primeira publicação que corresponde a novembro de 1905, as demais revistas não possuem indicação do mês da publicação. Após a de novembro há mais três publicações, as quais supomos que sejam referentes a dezembro de 1905, janeiro e fevereiro de 1906 . 
A representação de operetas prevalecera, nos anos iniciais do século, sobre os demais gêneros teatrais, como as revistas, o teatro declamado e até mesmo as óperas. A partir de um levantamento realizado nas revistas literárias, percebemos que o seu auge ocorreu no período compreendido entre 1907 e o final de $1913^{25}$, quando as representações começaram a escassear. Segundo estudos de Magaldi e Vargas ${ }^{26}$, apresentaram-se em São Paulo até 1907 a Companhia italiana de Operetas e Ópera Cômica (Zucchini-Ottonello), Companhia Infantil Espanhola de Operetas e Zarzuelas, Companhia Francesa de vaudeville e a Companhia de Operetas, Mágicas e Revistas do Teatro Apolo Carioca. Quanto ao teatro declamado subiram ao palco os seguintes artistas: Coquelin, Réjane, Clara della Guardia, Tina di Lorenzo, Suzanne Desprès, Salvini, Eleonora Duse e a estrela Sara Bernhardt. O periódico Vida Moderna noticia também o sucesso da Companhia Marchetti no Moulin Rouge, em 1907.

Os anúncios de encenações de operetas começam a rarear ao mesmo tempo em que as companhias estrangeiras encontram dificuldades para atravessar o oceano. A deflagração da Primeira Guerra dificultou a vinda de companhias estrangeiras para a América Latina. O viés positivo, para as artes brasileiras, deste triste episódio da história mundial, foi o fortalecimento do nosso teatro. Com o receio de enfrentar as viagens marítimas, as companhias estrangeiras deixaram de nos visitar com freqüência, e as que aqui se encontravam foram obrigadas a ficar e se adaptar à nova situação. Com o palco livre da dominação forasteira, surgiram oportunidades para que os nossos atores se organizassem e mostrassem o seu trabalho. Por esse motivo, somente em 1913, conseguimos localizar uma notícia com informações da montagem de uma opereta realizada por uma companhia nacional. A peça era Gatinha Branca, produzida pela Companhia Nacional de Operetas, em julho de 1913. Em seguida, tivemos, em 1914, Sonho Fatal, de A.

\footnotetext{
25 É importante relembrar que, como foi dito na Introdução, a dificuldade de acesso a muitos periódicos deixou lacunas de alguns anos no nosso trabalho. Revistas anteriores a 1907 são poucas e, quando havia, essas não reservavam muito espaço ao teatro, exceção feita à revista Íris. 26 MAGALDI, Sábato e VARGAS, Maria Thereza Vargas. Cem anos de teatro em São Paulo (1875-1974). São Paulo: Editora SENAC, São Paulo, 2000.
} 
Tavares e O Moleiro de Alcalá, de Eduardo Garrido, português que se radicou no teatro brasileiro. A respeito desse homem de teatro escreveu Eduardo Victorino ${ }^{27}$ :

O panorama teatral modificou-se, em Portugal e no Rio, graças à vivacidade expressiva e original desse espírito incansável que, com tão ardente fantasia e tão perfeito conhecimento da carpintaria cênica, passava da comédia ao vaudeville e da opereta à mágica, numa eloqüente afirmação de homem espirituoso e de grande talento. ${ }^{28}$

Eduardo Victorino, futuramente, estrearia a própria companhia, tendo à frente a atriz Abigail Maia.

De 1901 a 1922, as companhias que representaram operetas nos palcos paulistas foram: Gattini-Angelini; Companhia Vitale; Città di Napoli; Companhia juvenil italiana dos irmãos Billand; Companhia do maestro Costa Junior; Companhia de D. Pablo Lopez; Companhia portuguesa Gomes \& Grijó; Companhia de José Ricardo; Companhia Galhardo; Companhia de Roberto Mário; Companhia de operetas e revistas do ator Domingos Braga; Companhia de operetas do maestro Lahoz; Companhia de operetas, mágicas e revistas do ator Brandão; Companhia Marchetti; Companhia Caramba; Companhia alemã Tuscher; Companhia do ator Alves da Silva; Companhia Camerata; Companhia Maresca; Companhia italiana de operetas do cômico Gravina; Companhia Renzi-Gabrielli; Companhia Christiano de Souza; Città di Roma; Companhia italiana de óperacômica Sconamiglio Caramba; Companhia de operetas e revistas "Rua" (da empresa J. Loureiro); Companhia de operetas Éden; Companhia Espanhola de operetas Aida Arce; Companhia Ítalo-Paulista; Companhia portuguesa de Henrique Alves; Companhia espanhola de zarzuelas Romo-Vinãs; Companhia de operetas e vaudevilles dos atores J. Rodrigues e A. Carvalho; Companhia de opereta Clara Weiss; Esperança Íris; Cooperativa Italiana de operetas de Luigi della Guardia; e a Companhia de operetas de Leopoldo Fróes.

27 Eduardo Victorino era português, mas participou ativamente da vida teatral brasileira. Atuou como ensaiador, empresário e professor na Escola Dramática do Teatro Municipal do Rio de Janeiro.

28 VICTORINO, Eduardo. Atores e atrizes. Rio de Janeiro, A noite Editora, 1937, p. 85. 
Em diferentes momentos encontramos o nome Companhia Juvenil Italiana, e, por falta de uma denominação mais específica, não sabemos se se trata da mesma companhia ou não.

Observando a relação acima, constatamos que muitas companhias que se apresentaram em São Paulo eram italianas. Segundo Miroel Silveira, a rota dos elencos italianos no século XIX era Buenos Aires - Montevidéu, Rio de Janeiro e Nova lorque. Entretanto, com a crescente imigração italiana em São Paulo, em fins do século XIX e início do XX, a cidade passou a constar nesse roteiro de viagem ${ }^{29}$.

As operetas cujos anúncios ou comentários recuperamos foram: Le P'tits Michú; Granatiere; Mmcelle Nituche; Orpheu no Inferno; Lagartixa; A Casta Suzanna; A Princesa dos dólares; Bella da Scozia; O Camponês Alegre; A Flor do Tejo; A Geisha; II Coscritto; Mulheres em peruca; O Conde de Luxemburgo; Os Saltimbancos; Amor de Zíngaro; Viúva Alegre; Eva, Manobras do Outono; 0 Mascote; O Processo Dreyfus; Amor de Príncipe; Sangue Vienense; Granadeiros; Sangue de artista; La donna Moderna; A grande avenida; $A$ filha do bandido; $O$ marido das três mulheres; Jockey-Club; A gran via; O Caro Agostinho; Sonho de Valsa; Sua Alteza Valsa; Dona Juanita; Fatinitza; Miss Helyett; II milionário accattone; Monsieur de La Palisse; Duchino; Maruxa; El assombro de Damasco; $O$ filho de meu marido; Amores de Tricana; Amores de Campônio; Sybill; Senhorita Tralalá; Príncipe de Mônaco; Rainha das Rosas; O Toreador, Mme de Thebes; $A$ Senhorita do Cinematógrafo; Gatinha Branca; O Moleiro de Alcalá; O Tesouro da Feiticeira; Sonho Fatal; Os Granadeiros; e Papá Guilherme.

Entre essas o público tinha preferência por Lagartixa, Casta Suzanna, A Princesa dos dólares, O Camponês Alegre, Amor de Zíngaro, Amor de Príncipe, Eva e Viúva Alegre.

A Casta Suzanna foi assim definida por Cícero Sylvestre, colunista de $O$ Pirralho: 
É uma peça livre e pouco apropriada aos pudicos ouvidos de uma donzela, porém engraçadíssima. ${ }^{30}$

Quanto aos autores de operetas destacaram-se: Suppé, autor de Dona Juanita; Franz Lehar, com Eva, A filha do bandido, O marido das três mulheres $e$ Amor de Zíngaro; Leo Fall, criador de A Princesa dos dólares e O Caro Agostinho; e Gilbert com La donna Moderna, e a opereta que mais vezes aparece nas pesquisas: A Casta Suzanna.

Orpheu no Inferno, a pioneira do gênero, e responsável pela transformação da cena teatral européia e brasileira, foi representada no Polytheama, em março de 1911, pela Companhia Ettore Vitale, que já estivera no Brasil em 1907. A crítica não considerou a encenação um triunfo da Companhia, sendo que a interpretação fora insatisfatória e não fizera jus aos personagens. Em dezembro de 1911, a companhia voltou a São Paulo, mas dessa vez foi aconselhada pelo crítico da Ilustração Paulista a não apresentar nada "às escâncaras". Uma vez que nas famílias paulistas havia muito pudor, tudo deveria ser velado e a companhia precisaria ter muito cuidado com as representações. Aliás, um mês antes da estréia, o crítico dessa revista já ansiava pela chegada da companhia e afirmava que ela poderia restaurar a ordem dentre a crise teatral; todavia só alcançaria êxito se não ferisse a moral e os bons costumes com imoralidades e gestos obscenos. $O$ colunista de $O$ Pirralho informou que a chegada desta companhia melhorou a cena teatral, apesar de em suas últimas temporadas ter desrespeitado o público "dizendo obscenidades em cena, enxertando tolices de todos os tamanhos". Nessa temporada de dezembro, obtiveram sucesso: A Casta Suzanna, Amor de Zíngaro, Manobras de Outono, Conde de Luxemburgo e Viúva Alegre. Em fevereiro de 1912, a Companhia Vitale embarcou para o Rio de Janeiro, mas em junho do mesmo ano já estava de volta, lotando o Polytheama novamente. A Companhia ainda faria uma temporada de março a maio de 1913.

30 O Pirralho, número 19, 16/12/1911, p. 10. 
Em maio de 1908, as atenções se voltaram para a Companhia de operetas do maestro Lahoz, cuja estréia se deu no Polytheama, na ladeira de São João, com a peça Robinson Crusoé, do maestro Dall'Argine.

Essa belíssima peça, montada com extraordinário luxo, foi levada à cena doze vezes, em meio de crescente sucesso. ${ }^{31}$

Em seguida, foi levada à cena a opereta "tão apreciada nesta capital" $A$ Geisha, de Sidney Jones, considerada um dos sucessos da trupe, devido não só à grandiosidade do cenário, mas também à boa interpretação dos artistas, com destaque para Margherita Scotti, possuidora de "afinada voz de soprano". Aproveitando a "maré de sucesso", a companhia apresentou ainda a ópera-cômica A filha do tambor-mor, de Offenbach.

A boa temporada da Companhia rendeu uma nota nas páginas da revista dirigida por Arlindo Leal.

Ora, graças, que a excelente trupe Lahoz veio nos alegrar de novo com o seu esplêndido repertório de operetas, cantadas a seu primor por artistas de bom nome e reputado mérito! Ficamos livres, felizmente, das trupes mambembes, de cantores afônicos, guindados à celebridade pela zabumba das reclames espalhafatosas e ridículas!... ${ }^{32}$

Após o sucesso de dois meses, a companhia despediu-se de São Paulo apresentando na penúltima récita a opereta // Coscritto, com letra e música do maestro Dall'Argine, e finalizou com $A$ Geisha, em homenagem ao bilheteiro do Polytheama, Pedro de Mendonça, "que teve o prazer de ver o teatro repleto das mais distintas famílias da nossa capital". Na capital fluminense a companhia estreou, em julho, no Palace Theatre, com grande aceitação da rigorosa e exigente crítica carioca, conforme o periódico Vida Paulista.

31 Vida Paulista, 17-18 de maio de 1908, número 119, Ano III. 32 Vida Paulista, 4 e 5 de julho de 1908, número 126, Ano III. 
A popular Viúva Alegre foi escolhida para a estréia da nova temporada da Companhia Lahoz em outubro de 1910. Um mês após a estréia, a companhia continuava obtendo êxito com a representação de $O$ Camponês Alegre, A Princesa dos dólares, Miss Helyett, A Geisha, e O Conde de Luxemburgo.

Em julho de 1912, a companhia retornou a São Paulo, estreando com $A$ Princesa dos dólares, no São José, e lá permaneceu até setembro do mesmo ano. Assim como a Companhia de seu conterrâneo Ettore Vitale, a Lahoz teve altos e baixos, ao apresentar um repertório com operetas já muito conhecidas, como $A$ Casta Suzanna, Eva, A Filha do bandido e O marido das três mulheres. Esta última foi descrita assim pelo crítico de O Pirralho:

O enredo é, como o da quase totalidade das operetas modernas, um mistifório de episódios extravagantes e ridículos. ${ }^{33}$

Ernesto Lahoz faria nova temporada de fevereiro a março de 1913.

Após uma temporada no Rio de Janeiro, a Companhia cômica italiana Marchetti chegou a São Paulo, em setembro de 1907. O colunista de A Vida Moderna refere-se ao grupo nestes termos:

O público paulista tem gosto e ama a arte dramática, principalmente no gênero adotado por essa rapaziada alegre e folgazã (...) As peças até hoje levadas por esta companhia, representam o que pode haver de mais original e novo no gênero cômico que é a sua especialidade. ${ }^{34}$

O seu repertório era composto por mais de setenta peças, todas muito bem ensaiadas, segundo A Vida Moderna. O grupo sob o comando de Marchetti faria nova excursão aos palcos paulistas de janeiro a março de 1912.

Os portugueses, como não podia ser diferente, também tinham seu público garantido por aqui. A temporada da Companhia Galhardo, do Teatro Avenida de Lisboa, em agosto de 1911, foi um sucesso. As peças representadas a pedido do

33 O Pirralho, número 55, 24/08/1912.

34 A Vida Moderna, número 24/ 17/09/1907, ano II, pg.10-12. 
público foram O Conde de Luxemburgo e a Princesa dos Dólares, com destaque para a atriz Cremilda de Oliveira. Essa companhia, sob a direção de Assis Pacheco, conseguiu algo inusitado: segundo a llustração Paulista, além de ser sucesso de público, o era também de crítica. O resultado desse triunfo só podia ser a casa lotada. $O$ Pirralho também divulgava o sucesso da Companhia com as peças A Divorciada e O Conde de Monte Cristo ${ }^{35}$.

O periódico O Queixoso, em um tom bem humorado, clamava aos nossos dramaturgos e "comedioturgos", tais como o Olival ${ }^{36}$ ou o Cardim, que tratassem logo de escrever suas "magníficas revistas" para os "latagões" e para as "saloias" do Galhardo, pois só assim nos livraríamos das "Viúvas Alegres, Condes de Luxemburgo, Sonhos de Valsas, e outras semelhantes "encrencas" do Chico Leal (em alemão Franz Lehar)." ${ }^{37}$

Nota-se que o repertório das companhias visitantes era sempre o mesmo. Fossem elas italianas, espanholas ou portuguesas as operetas se repetiam. O público parecia não se importar ou se cansar, pois a cada temporada os teatros recebiam "verdadeiras enchentes" (expressão muito usada nos periódicos) de público. O que interessava ao público eram as diferentes interpretações oferecidas pelos atores, os cenários e o luxo da companhia.

Até uma Companhia alemã de operetas teve seu espaço na cena brasileira dominada pelo teatro estrangeiro. A Companhia alemã Tuscher estreou em junho de 1913 com a peça Eva, "uma das operetas mais queridas do nosso público". A representação de Sua Alteza Valsa, em homenagem ao aniversário da subida do Kaiser da Alemanha ao trono, leva-nos à conclusão de que cada Companhia já tinha um público alvo definido, uma colônia de imigrantes que se identificava com suas origens, dada a peculiaridade do assunto da peça. Tal fato não descarta outro tipo de platéia para essas companhias.

No final do segundo decênio do século, a inauguração de um novo teatro em São Paulo seria um assunto de grande alegria para a imprensa, a não ser por um

35 O Pirralho, número 02, 1/08/1911, ano I.

36 Olival Costa escreveu em parceria com Gomes Cardim a peça Anita, que conta um episódio da Guerra do Contestado, conforme O Pirralho, 30/10/1915. Ele também é autor da opereta regional Nhá moça, representada pela Companhia Arruda.

37 O Queixoso, número 1, 09/12/1915, ano I, pp.12-13. 
detalhe. O teatro Santana, idealizado pela Condessa Penteado, abriria suas portas, em 1921, com a Companhia Clara Weiss. O Correio Musical Brasileiro censurou veementemente a escolha. Em primeiro lugar, por não ter sido escolhida uma companhia nacional, como a de Leopoldo Fróes ou de Gomes Cardim; e em segundo, por ser uma companhia de operetas. A opinião do redator da revista é categórica em relação ao gênero:

As companhias de opereta, chamem-se elas Weiss ou Esperanza Íris, não fizeram, não fazem e nunca farão arte: péssimos cantantes e maus atores formam em geral os conjuntos operetísticos que devem interpretar os repertórios (os modernos principalmente) compostos de trabalhos sem sentido e licenciosos feitos para gáudio de basbaques que apreciam e se divertem ao ouvir frases de "double face"... ${ }^{38}$

A Companhia espanhola de operetas Esperanza Íris estivera em São Paulo em fevereiro de 1916 com a peça El mercado das muchachas. A trupe, já conhecida pelo público, obteve sucesso. Segundo O Pirralho, o público paulista, na ocasião, há muito ansiava por uma companhia de operetas - lembrando que com a guerra as companhias estrangeiras rarearam por aqui - e certamente se divertiria com o grupo espanhol. Apesar da carência de alguns elementos, a companhia satisfez seu público.

O elenco é homogêneo, os coros têm altos e baixos, o guarda-roupa não é dos piores e a orquestra dá conta do recado. ${ }^{39}$

Dado o fim da opereta ser divertir e não deleitar, conforme acreditava o crítico, era fácil cair na vulgaridade e incoerência.

Clara Weiss também estivera no Brasil em 1916 com a Companhia italiana de operetas Maresca Weiss, apresentando A Casta Suzanna, no teatro Apolo. A atuação da companhia nessa peça não agradou o público. Superado o fracasso de A Casta Suzanna, a companhia obteve êxito representando $A$ Senhorita do

38 O Correio Musical Brasileiro, número 2, 15-31/05/1921, ano I, p. 7. 39 O Pirralho, número 212, 08/02/1916. 
Cinematógrafo, que "atraiu ao teatro da rua do Anhangabaú uma enorme massa de gente, que se divertiu a valer". A peça agradou tanto que o colunista exagerou:

"Muitos ficaram com dor de barriga de tanto rir". ${ }^{40}$

A opereta sempre fora acusada de subverter o gosto do público, de conter obscenidades e vulgaridades e de ser uma forma menos expressiva de arte, voltada para um público menos exigente e menos capacitado. Entretanto, apesar das críticas, era o tipo de espetáculo que mais pessoas levava ao teatro e que mais sucesso fazia. Gostando ou não, alguns se renderam ao "triunfo da opereta".

$\mathrm{E}$, demais em que pese os adeptos do Teatro da Alma, à intransigência dos psicólogos da ribalta, o teatro popular ainda é o soberano a cuja voz as platéias se enchem. ${ }^{41}$

40 O Pirralho, número 216, 04/04/1916.

41 lustração Paulista, número 19/13/05/1911, ano I. 


\subsection{A Ascensão das revistas}

A primeira revista brasileira, As surpresas do Senhor José da Piedade, data de 1859. Entretanto, a sua representação não obteve o acolhimento esperado do público, o qual não estava ainda acostumado às críticas sociais e políticas apresentadas pelo gênero. Após algumas tentativas malfadadas de inserção desse tipo de espetáculo, estréia, em 1884, O Mandarim, de Artur Azevedo, que abriu definitivamente as portas do teatro ao gênero revista.

Segundo Neyde Veneziano, as revistas de ano tinham por objetivo, como o próprio nome revela, passar em revista, ou seja, re-visar fatos e acontecimentos do ano anterior. Para isso era necessário que os autores estivessem a par de fatos políticos, sociais e culturais que afetavam o país, e principalmente a cidade em que a peça seria representada.

A revista de ano possuía um enredo básico, cuja ação girava em torno de uma perseguição provocada por alguém que se perdia na cidade grande, ou ainda um personagem que chegava para conhecer a capital. Essa movimentação possibilitava o deslocamento dos personagens por diversos ambientes e o contato com diferentes situações e problemas. Havia alguns quadros obrigatórios, como o quadro da imprensa, em que se discutiam as notícias dos periódicos; o dos teatros, que comentava as peças em cartaz; a caricatura de pessoas importantes da política; e as apoteoses, destacando algum momento histórico importante ou de grande relevo. O principal objetivo desse teatro era a diversão, mas nem por isso são deixadas de lado as questões políticas e sociais, mesmo que de forma amenizada.

Décio de Almeida Prado afirmou que a revista não possuía enredo ou dele não necessitava; sua unidade era mantida através da figura do compère (compadre), o personagem responsável por apresentar os quadros e comentá-los, mantendo uma relação cúmplice com a platéia ${ }^{42}$. Com o passar do tempo, o gênero sofreu transformações, deixando de re-visar os fatos de anos anteriores, e a figura 
do compère não se fez mais necessária, uma vez que os quadros isolados passaram a ser mais valorizados.

O teatro de revista no Brasil teve uma duração de cem anos. De acordo com Delson Antunes, o fenômeno teatro de revista foi o mais forte e duradouro movimento de teatro popular no país ${ }^{43}$. No entanto, podemos supor que tenha sido tão discriminado e marginalizado pelos intelectuais, e acusado de ser um dos fatores da "decadência do teatro brasileiro", por ser voltado, principalmente, "às massas".

É necessário retratar brevemente o sucesso alcançado pelo teatro de revista no Rio de Janeiro, a fim de compará-lo com o de São Paulo. Esse gênero se firmou na antiga capital brasileira graças ao talento da dupla Artur Azevedo e Moreira Sampaio. Com o passar do tempo, o tema central das peças deixou de ser 0 encantamento pela Corte, e passou a ser as transformações ocorridas na Capital Federal.

As modificações urbanas, os flagrantes políticos e os tumultos estimulavam os autores a exercitarem suas críticas talentosas. Felicíssimos retratos desta jovem república brasileira foram pintados por Artur Azevedo. Era a revista registrando os acontecimentos e glosando-os. ${ }^{44}$

Companhias interessadas em pegar carona no sucesso da revista começaram a aparecer. Dentre essas se destacaram a Companhia de Operetas, Mágicas e Revistas do Teatro São José, sob a direção de Pascoal Segreto e a Companhia de José Loureiro, a quem pertenciam os teatros Apolo e Recreio.

Em 1908, a atriz Cinira Polônio criara os espetáculos por sessões. O sucesso conquistado pelas revistas surpreendeu tanto que a solução foi adotar esse esquema de três sessões diárias (às dezenove horas, às vinte e quinze e às vinte e duas e trinta), sem descanso semanal. Além disso, os atores passavam o dia inteiro ensaiando, já que as montagens não demoravam muito tempo em cartaz.

43 ANTUNES, Delson. Fora do Sério: Um Panorama do Teatro de Revista no Brasil. Rio de Janeiro, Funarte, 2002. 44 VENEZIANO, Neide. Op. cit. p. 36 
Após a Primeira Guerra Mundial, a revista, sem receber influência estrangeira, passou a utilizar mais do elemento nacional e ligou-se fortemente à música popular, divulgando as marchinhas carnavalescas. Em 1922, com a chegada da Companhia de revistas francesas Ba-ta-clan, os espetáculos de revista tomaram um rumo diferente, no qual prevalecia o luxo, a fantasia e o número de vedetes.

A precursora do gênero em São Paulo foi a revista de ano $O$ Boato, de Arlindo Leal. A peça passava em revista os acontecimentos dos anos de $1897 \mathrm{e}$ 1898. O seu fio condutor retratava um casal de caipiras, vindo de Araras, interior de São Paulo. O casal, Quitéria e Anastácio da Sapucaia, vinha com a filha Dorinha para assistir ao carnaval da capital do estado. Conforme conhecem a cidade grande, metem-se em grandes confusões. O tema central da peça é o boato, histórias que as pessoas passam umas às outras.

Anos mais tarde, Arlindo Leal lamentaria ter dado essa contribuição ao teatro musicado. Ao comentar as produções predominantes na cena nacional, 0 dramaturgo afirmou que "além do gênero revista (em que o autor deste artigo também cometeu o seu pecado)" as peças encenadas nesse momento -as operetas - valorizavam somente o dito chulo e frases ambíguas ${ }^{45}$. Apesar desse comentário, Arlindo Leal escreveria outras revistas nos próximos anos.

O mote mais agradável ao público paulista era o do sertanejo na capital e o retrato de seus imigrantes - principalmente os italianos - passeando pelo Largo do Arouche ou pela Rua Direita. A mistura de idiomas e sotaques era também uma característica importante da vida paulistana e aproveitada pelas revistas. Longe do brilho, luxo e fantasia da noite carioca, a diversão paulistana era voltada para toda a família.

A primeira informação, no material coletado, sobre a montagem de uma revista nos palcos brasileiros aparece em $A$ Vida Moderna, na edição de 31/07/1907. A peça era a conhecida Tintim por Tintim, de Souza Bastos, apresentada pela primeira vez no Brasil em 1892. A montagem de 1907 estreou no Polytheama com a Companhia de Operetas, Mágicas e Revistas do ator Brandão.

45 Íris, Vol. I, 1906, pp.192-195. 
O anúncio para a semana seguinte prometia $A$ Capital Federal, de Artur Azevedo, classificada como revista. Neyde Veneziano, porém, a define como opereta e esclarece que tal confusão se dá porque $A$ Capital Federal foi desenvolvida a partir da revista de ano 0 Tribofe ${ }^{46}$. Outras vezes a peça recebeu a designação de burleta, confirmando, mais uma vez, os estreitos limites entre os gêneros do teatro musicado.

Novamente recorremos a Neyde Veneziano:

A burleta é uma comédia musical com andamento mais rápido e falas entremeadas de cançonetas. Pode-se dizer que, na burleta, as músicas são mais populares do que na opereta. ${ }^{47}$

A palavra burleta vem do vocabulário teatral italiano, sendo também usada em Portugal. Décio de Almeida Prado considera que talvez seja o "rótulo" mais apropriado para as peças despreocupadas com a estética literária e formadas, ao mesmo tempo, da comédia de costumes, da opereta, da revista e até da mágica ${ }^{48}$.

Em setembro de 1907, a Companhia do ator Brandão apresentou a revista paulista Vai ou Racha, no Polytheama. A crítica não poupou o fraco desempenho da companhia.

Esta peça não passou de um verdadeiro conto do vigário, muito pecando pela absoluta falta de espírito e nexo. ${ }^{49}$

A autoria dessa peça não é conhecida. A princípio, a revista fora atribuída a Gomes Cardim ${ }^{50}$ e Venceslau Queirós, mas isso foi logo desconsiderado. O periódico $A$ Vida Moderna acha possível ser de Assis Pacheco, mas não confirma a suspeita, e coloca um ponto de interrogação ao lado da nota. Outra hipótese

46 VENEZIANO, Neyde. Op. cit. p. 84.

47 VENEZIANO, Neyde. Op. cit. p. 76.

48 PRADO, Décio de Almeida. Op. cit. p. 148.

49 A Vida Moderna, número 24, /17/09/1907, ano II, pg.10-12.

50 Pedro Augusto Gomes Cardim atuou intensamente na vida teatral do século XX. Foi fundador do Conservatório Dramático e Musical, diretor da Companhia Dramática Nacional e escreveu algumas peças, tais como O Baronato, O primeiro cliente, entre outras. 
levantada é de a revista ser do próprio Brandão. No entanto, nenhuma dessas possibilidades é comprovada.

No primeiro decênio do século $X X$, o gênero predominante nos palcos paulistas era a opereta e não a revista. Após as montagens de 1907, a revista só volta a aparecer com mais força em 1911, e, a partir daí, começa a conquistar seu espaço.

A revista de costumes nacionais Paz e Amor é apresentada no Variedades em agosto de 1911 pela Companhia Lírico Cinematográfico. O nome da companhia nos dá indícios do crescente interesse por essa arte.

Novembro é o mês de uma trupe luso-hispano-brasileira tentar o sucesso com Tintim por Tintim e Vinte e oito dias de Clarinha, mas, conforme Mário Mariz, da Ilustração Paulista, o resultado não foi o esperado, pois o grupo pouco entendia do "savoir-faire".

Em 1911, registram-se ainda as representações de Os dois nenéns, com Arruda no "seu melhor papel" ${ }^{1}$ e A Grande Avenida, pela trupe Taveira, que segue até o início de 1912, acrescentando ao seu repertório $A$ mala de João Cândido e o grande sucesso Do Inferno a São Paulo, um arranjo do ator Arruda -aquele que será o grande nome do teatro paulista do início do século XX - e de Francisco de Camargo Penteado, um acadêmico de Direito.

As companhias estrangeiras, em uma atitude cortês, vez ou outra, apresentavam originais de autores brasileiros ou que aqui atuavam. Tal fato se deu com a representação de Babel Revista, escrita especialmente por João Phoca, para a Companhia juvenil italiana dos irmãos Billand, que atuava no Palace Theatre, em fevereiro de 1913. Babel Revista já havia sido sucesso de público no Rio de Janeiro. João Phoca encarregou-se do prólogo. Dentre os números que se destacaram foram citados o Guarda-noturno do Forrobodó, pelo Gamba; Corta Jaca e Pimentinha, pelo Gamba e Ceccarelli; Maxixe Aristocrático; e Vassourinha, por Dora e Donatti. A crítica elogiou a atuação dos atores e a peça fez um enorme sucesso ${ }^{52}$.

51 O Pirralho, número 19, 16/12/1911, ano I 52 O Pirralho, número 77, 08/02/1911. 
Ainda esse ano registra-se o sucesso de Já te Pintei e O Chegadinho, em fevereiro, no Variedades. Em julho, a Companhia Nacional de Operetas, representava a revista Jocotó, no Palace Theatre.

Danton Vampré, em parceria com João Felizardo, apresenta em 1914 a revista responsável, no futuro, por um dos maiores êxitos da Companhia Arruda: São Paulo Futuro. Com música do maestro F. Lobo, a revista estreou no São José atraindo a atenção da imprensa e do público. Esse escritor viria a ser um festejado revisteiro no meio teatral paulista. Em julho, de 1918, O Pirralho dedica um artigo a Danton Vampré, elogiando seus feitos e qualidades.

Se o nome é francês, o indivíduo é brasileiro "vieux type", com todas as qualidades da raça. É um moço cheio de talento e, o que mais é, cheio de verve. Dedicou-se ao teatro. Possui diversos e múltiplos talentos, mas a sua especialidade é o teatro, tendo obtido, como revistógrafo e autor de burletas, vitórias até hoje ainda não conquistadas, em nosso meio, por ninguém. Por ninguém! ${ }^{53}$

De fato, Danton Vampré foi o revisteiro paulista de maior destaque. Das montagens realizadas pela Companhia Arruda, as três que obtiveram o maior número de representações foram de sua autoria: Uma festa na freguesia do Ó, 66 vezes; São Paulo Futuro, 55; e Sustenta a nota, $46^{54}$.

Seguindo a fórmula inicial da revista - a não ser pela divisão em dois atos São Paulo Futuro traz um compère (o compadre) e um fazendeiro caipira, Gaudêncio ${ }^{55}$. A cidade, Paulicéia, seria apresentada ao fazendeiro pelo Dr. Barriga Verde. Nessa visita, encontram vários personagens, entre eles o Italiano. Há também os personagens alegóricos, tais como a Light, o Bonde Caradura, a Cidade, o Café, o Cinema, a Moda, entre outros. A "alma da academia", referência à Faculdade de Direito, é a apoteose do final do $1^{\circ}$ ato.

A revista, montada inicialmente pela Companhia do ator Brandão, ficou em cartaz de 14 de março a 31 de maio de 1914. Em outubro, após passar por uma

53 A Vida Moderna, número 341, 13/08/1918, ano XIV, 13/08/1918.

54 A Vida Moderna, número 340, 25/07/1918.

55 Sobre a estrutura do gênero revista ver: VENEZIANO, Neyde. O teatro de revista no Brasil. dramaturgia e convenções. Campinas: Editora da Unicamp: Pontes, 1991. 
série de transformações, voltou a estrear no São José. Desta vez, porém, a crítica Ihe foi severa e afirmou que as modificações não foram suficientes para que se retirassem "as verdadeiras excrescências do seu trabalho". ${ }^{56}$

Essa peça encontra-se disponível para consulta no Arquivo Miroel Silveira ${ }^{57}$. Analisada pela censura em 1931, foi liberada para representação com alguns cortes. Na folha de rosto do processo registra-se: São Paulo Futuro. Revista em três atos do Dr. Danton Vampré, música de Marcelo Tupinambá.

Extraímos trechos da peça a fim de mostrar por que a revista era alvo de críticas negativas.

\section{A Senhora do cachorro}

Maricota - Ah! Ah! Ah! Ah!

Gaudencio - O que foi D. Maricota? Não tem vergonha de andá chorando no meio da rua? O que foi que lhe sucedeu?

Maricota - Ah! Seu Gaudencio, uma horrível desgraça; imagine que meu marido desprezou o meu Joly, o meu cachorrinho de estimação.

Gaudencio - Que me diz D. Maricota?

Maricota - É isso mesmo; imagine seu Lucas que quando ele vem pra casa não se importa com o meu cachorro como dantes; não lhe faz festas, não o acaricia, não o beija. Antigamente trazia-lhe um pedaço de lingüiça do armazém. Ah! Ah! Ah! Imagine que o cachorro agora anda triste, não come nada, só quer comer lingüiça.

Gaudencio - E por que D. Maricota?

Maricota - É porque mudou lá pra perto de casa uma viúva que tem um cachorro muito grande: desses que têm o pêlo muito liso, muito macio.

Gaudencio - Já sei, é um cachorro Parisiense.

Maricota - Não, disseram-me que é o cão de fila.

Gaudencio - Cão de fila, não sei.

Italiano- Oh! Há muito cachorro no Brasil. Há pouco morre um e agora outro abandonado. 
Gaudencio - Naturalmente. Toda mulher bonita tem o seu cachorro para andar com ele, puxando pela mão e às vezes é cada cachorro baita. Mas quem sabe $D$. Maricota, às vezes a gente se engana e...

Maricota - Não é engano, sr. Gaudencio, ainda o outro dia o apanhei em flagrante, fazendo festas ao cachorro da vizinha, por um buraco que tem no muro do quintal Gaudencio - Que miserável!

Maricota - Eu Ihes conto. (canta)

O meu maridinho

Que era tão bonzinho

Tinha um tal cuidado

Pelo cachorrinho

Vivia a alisá-lo

E com tal carinho Que era um regalo.

Para o coitadinho

Agora não gosta

Mais do meu cãozinho.

Gaudencio - Por quê?

Maricota- Vive a fazer festa.

Gaudencio - A quem?

Maricota - Ao cachorro grande.

Gaudencio- De quem?

Maricota - Da minha vizinha.

Segundo ato

O Progresso

Cena II

Italiano- Ma que prigresso. Nô incurta niente lo que incurta é la vida dos outro. Questo é uma porqueria.

Gaudencio - Sim sinhô. Gostei de vê. Que progresso.

Italiano - Ma que bostia. lo no ho veduto niente.

Gaudencio - Tu é que é indecente, cara de cavalo pelado. Tu sabe com que tá falando?

(...)

Italiano - Má que niente. 
Gaudêncio - Já disse que tu é que é um indecente. Então tu acha pouco andá sem cavalo, sem burro, só serve para fazê estegolomia.

Italiano - Má que cosa é estegolomia?

Gaudencio - Tu não sabe o que é estegolomia? Estelegomia é uma palavra que vem do alemão. É assim como quem diz estegolo e mia. Estegolo que vem de esterco e mia que é um mosquitinho que faz assim na oreia da gente.

Italiano - Inda a orechia! Oh! Capute. Questo é uma porqueria.

Gaudencio - Quá porcaria quá nada.

Italiano - Má o signore no escuitô o cheirinho indisgraciato qui vai do canudo detrás da fumaça. É uma porqueria.

Gaudencio - Quá canudo. Quá nada. Quanta coisa tem canudo, tem mau cheiro e a gente gosta.

Italiano - Má isso é uma porqueria.

A linguagem dúbia da peça era acusada de chula, pornográfica e imoral, portanto não servia para ensinar a moral e os bons costumes.

Mais uma revista de costumes paulistas estreou em outubro de 1914. Sob a direção de J. Gonçalves, a Companhia Nacional de Operetas, Mágicas e Revistas apresentou Só pr' falar, de Cardoso de Menezes. Segundo a imprensa, apesar de seus defeitos, que não eram poucos, a revista, um tanto apimentada, tinha "críticas felizes a fatos da vida paulistana e boa movimentação" ${ }^{58}$

Cardoso de Menezes era um revisteiro conceituado no Rio de Janeiro. Esse dado evidencia que a influência carioca fazia-se presente no teatro feito em São Paulo. Eis o que afirmam Sábato Magaldi e Maria Thereza Vargas:

Mas o teatro será paulista apenas pelo assunto, porque as fórmulas e a maneira de ser continuam firmemente cariocas. ${ }^{59}$

Essa observação não enfraquece o movimento teatral paulista que se mostrava cada vez mais promissor.

58 O Pirralho, número 157, 17/10/1914.

59 MAGALDI \& VARGAS. Op. cit. p. 62. 
Em meio às montagens de teatro de revista, os alunos do Conservatório Dramático e Musical de São Paulo, em seu programa da festa de encerramento do Curso Dramático, anunciam a apresentação de O Oráculo, de Artur Azevedo, em novembro de $1914^{60}$.

Mas esse era o ano das revistas paulistas, pois em dezembro é lançada São Paulo em Fraldas, de Ricardo de Oliveira, E. Paiva Rio e música do maestro Bentinho Cintra. O Pirralho informa-nos que o teatro esteve lotado e que o espetáculo agradou completamente ${ }^{61}$. A leitura dessa peça, em abril, já indicara o seu futuro êxito. D. Pasquale, da Revista Teatral, Sport, Arte e...o que for caracterizou-a nesses termos: "é bem feita, com espírito, e, sobretudo, sem pornografia"62.

A fama de imoral e pornográfica começava, portanto, a se associar às revistas.

Paiva Rio ${ }^{63}$, um dos autores de São Paulo em Fraldas, prometia para breve uma revista com o "sugestivo título" Depois te explico, com música do maestro Chagas Júnior. O crítico da Éden Revista, após conhecer algumas cenas desse novo trabalho, garantiu que a peça já estava fadada a fazer sucesso pela "verve e crítica fina" com que vinha sendo escrita ${ }^{64}$.

O próximo ano, 1915, também foi promissor ao gênero. O Grêmio Dramático Santa Cecília que, apesar de amador, conseguia manter uma certa rotina de apresentações encenou Uma festa em Guabiroba, de Assis Pacheco e Tintim Mirim, sendo muito elogiado pela crítica.

A Companhia do Teatro São José do Rio de Janeiro, da qual faziam parte Cinira Polônio e Pepa Delgado, trabalhou uma temporada no São José de São Paulo, também de propriedade de Paschoal Segreto, e obteve êxito com a revista carnavalesca Zig-Zag-Bum! e a revista Chuá.

Cinira Polônio, que estivera antes em São Paulo na Companhia do ator Brandão, dessa vez também colheu elogios.

\footnotetext{
60 O Pirralho, número 163, 28/11/1914, ano IV.

61 O Pirralho, número 165, 12/12/1914.

62 Revista Teatral, Sport, Arte e...o que for, 23 de Abril de 1914, ano I, n. .7 .

63 O autor é chamado de Paiva Rio por O Pirralho e Paula Rio pela Éden Revista.

64 Éden Revista/ Revista Theatral e Cinematográfica, número 12, março de 1915, ano III.
} 
...essa artista inteligente e esmerada, culta e estudiosa, cuidadosa e apaixonada pela arte que abraçou e que tantos louros lhe tem dado... ${ }^{65}$

Em abril, tivemos a revista Banho de Vênus, de J. Brito e música de Felipe Duarte, realizada pela companhia de Eduardo Vieira. Sobre a peça, escreveu João Felizardo:

Perfeita divisão dos quadros, profusa distribuição de espírito malicioso à brasileira, versos bem feitos, diálogo leve e bem cuidado...

A música, (seria bastante dizer-se que é de Felipe Duarte) delicadíssima. ${ }^{66}$

Os papéis foram distribuídos entre os seguintes atores: Davina Fraga, Guilhermina Rocha, Luiza de Oliveira, Estela Pardil, Eduardo Vieira, Judith Garcez, Ramos, Rangel, Torres e Castelo Branco.

A Companhia Galhardo estreou no Palace Theatre, em maio de 1915, com a revista $O$ 31, de Luís Galhardo, Pereira Coelho e Alberto Barbosa, música de Thomas Del Negro e Alves Coelho. O resultado desse encontro entre autores e músicos foi excelente, de acordo com a imprensa. A atuação dos dois compères, Carlos Leal, como o "17", e Antonio Gomes, como o "31", cativou o público, arrancando-Ihe boas gargalhadas.

O 31 é suculenta. Do princípio ao fim esfuzia a boa graça portuguesa. Número de incontestável arte, apoteoses de magnífico efeito. A música muito fina e apropriada, com ótima orquestração. ${ }^{67}$

A Companhia prosseguiu a temporada com Mar de Rosas, De capote e lenço e Pão Nosso. A respeito dessa última, Felizardo comentou:

65 Éden Revista/ Revista Theatral e Cinematográfica, número 12, março de 1915, ano III. 66 O Pirralho, número 183, 17/04/1915, ano IV

67 O Pirralho, número 186, 08/05/1915, ano IV 
O Pão Nosso é outra bela revista, de atualidade, com crítica fina, graciosa e às vezes cruel dos acontecimentos políticos de Portugal. A música é muito graciosa e viva e os versos é puro (sic), bem feitos. ${ }^{68}$

A representação de Mar de Rosas, porém, não agradou tanto. A revista "arrastou-se" durante três horas, e os compères Carlos Leal e Jaime Silva não conseguiram tirar melhor proveito das cenas. Destaque para o quadro "Pierrot Columbina e Mephisto", o quadro crítico das misérias do Brasil e "o vaqueiro de Pernambuco" $"$.

A manifestações contrárias ao teatro de revista começaram a surgir pouco a pouco. João Felizardo relata que uma colega de imprensa publicara nota informando que o Trianon, da Avenida Rio Branco, no Rio de Janeiro, tornara-se o ponto preferido do público chique, da platéia que não apreciava revistas ${ }^{70}$. Tal fato se consolidava com a estréia da Companhia de Leopoldo Fróis, nesse teatro, vindo dar ânimo novo na cruzada rumo à criação de um verdadeiro teatro nacional.

O crítico, porém, desdenhou dessa afirmação, e considerou injusta a alusão da colega ao gênero, uma vez que havia "revistas e revistas", segundo seu entendimento. Ademais, o gênero era muito apreciado pela platéia de São Paulo, dado o sucesso de 031 , prestes a chegar ao cinqüentenário.

Essa mesma platéia, ainda de acordo com Felizardo, sabia ser criteriosa e escolher a que assistir. Não era composta de pessoas que corriam para ver as operetas italianas, pois essas se compunham daqueles que entendiam a língua ou fingiam entendê-la. Também dela não faziam parte os que davam estrondosas gargalhadas a uma gracinha pequenina, e nem os que freqüentavam teatro por esnobismo quando aqui se apresentavam o Novelli ou o Stracciari.

A platéia paulista, de que trata o crítico, apreciava a Companhia Galhardo, no Palace Theatre, mas ansiava por assistir à representação de uma peça genuinamente brasileira, ou melhor, paulista, com autores e atores nacionais.

68 O Pirralho, número 187, 15/05/1915, ano IV. 69 Idem, ibidem. 
A distinção entre o público apreciador de revistas e o público admirador do teatro sério dava seus primeiros passos, em relação às revistas. Tiago de Melo Gomes, em seu livro Um espelho no Palco, reflete sobre a questão da identidade nacional, através do teatro de revista, e observa a atuação da imprensa frente a esse tipo de espetáculo. A partir dessa reflexão, desenvolve a idéia de que a imprensa no início do século XX tinha o claro propósito de fazer distinção entre as classes sociais: a elite e as massas ${ }^{71}$.

Felizardo continua, no texto anterior, a afirmar que o nosso público não se compõe de literatos e de gente de igual cultura, assim como não é composto por freqüentadores de circo de cavalinhos. Enfatiza a necessidade de lembrar que enquanto o romance e a poesia acompanharam a marcha ascendente da cultura de uma classe, o teatro ficou com a massa popular e deve sempre ser reflexo dela. A reflexão do crítico nos mostra que essa tese da divisão de classes estava tão em voga, que, mesmo não querendo ser preconceituoso, o autor o é.

Em 1920, quando as críticas ao gênero estão em alta, Claudio, de $A$ Vida Moderna, enfatiza a diferença entre as revistas, com seus títulos "carnavalescos cheias de espírito doublé", e as peças apresentadas por Leopoldo Fróes:

São estas peças, levadas agora no S. José, todas as noites repleto de gente de bom gosto, que devem ser as preferidas pela elite paulistana. As outras, as revistas de ano e as pornográficas faz-se-ia ( $\mathrm{sic}$ ) um ótimo serviço se as boicotassem. ${ }^{72}$

Claudio assegurava que o teatro nacional vivia em ânsias de formação desde João Caetano. Dizia que o nosso teatro vinha se mantendo de aparições esporádicas de peças sofríveis, e que, mesmo amparado muitas vezes por homens ou artistas de talento, via-se reduzido à "pulhice das mágicas e à imbecilidade das revistas de ano, com apoteoses de papelão pintado e pornografia dialogada". ${ }^{73}$

\footnotetext{
71 GOMES, Tiago de Mello. Um Espelho no Palco: Identidades Sociais e Massificação da Cultura no Teatro de Revista dos anos 1920. Campinas, Ed. da Unicamp, 2004. 
O tema "a decadência do teatro nacional" voltava à pauta de discussões e colocava a revista como uma das responsáveis. A acusação se direcionava aos escritores, que, se tinham talento, preferiam escrever romances; aos atores, classificados como de quarta ordem; e ao público "de quinta". Assim, o nosso teatro, "caquético e imbecil" seguia representando "revistas de ano para ganhar dinheiro sórdido"74.

Na medida em que o gênero se fortalecia, as críticas negativas tornavam-se freqüentes. Voltando a acompanhar ano a ano a evolução do gênero na cena paulistana, encontramos, em uma coluna teatral de 1915, o anúncio da temporada de uma companhia, cujas palavras apresentam um teor radical:

A Companhia de revistas e outras drogas que trabalha neste teatro vai cavando a vida na medida de suas forças. ${ }^{75}$

Em 1916, os periódicos se ocuparão principalmente das peças Mon Coeur balance e Leur Âme, de Oswald de Andrade e Guilherme de Almeida.

A principal notícia de 1917 é a temporada da Companhia Arruda. Essa companhia, fundada em agosto de 1916, tendo à frente Abílio de Menezes e o ator Sebastião Arruda - o melhor representante do tipo caipira no período - desde o seu surgimento começou a se destacar na cena paulistana.

Com o prestígio alcançado na cidade, a Companhia do ator Arruda apresentou, em agosto, em primeira récita a burleta Uma festa no Ó, de Danton Vampré, João Felizardo, e música do maestro Lorena.

A crítica, ao fazer uma avaliação da montagem, classificou o gênero como chulo. E foi além, equiparando as palavras "popular" e "chulo", no comentário sobre a recepção do espetáculo.

A gente não quer num gênero popular e chulo como é o da revista, ver qualidades literárias ou lobrigar a verve sutil e muita vez imperceptível que brota da pena dos Cavaillet para ser proferida pelos lábios elegantes e carminados dos Brulé... ${ }^{76}$

74 A Vida Moderna, número 376, 12/02/1920, ano XVI. 75 O Pirralho, número 176, 27/02/1915. 
Como o público, apesar das críticas, gostou da peça, foi, mais uma vez, acusado de não saber apreciar arte de boa qualidade.

Mas o público aprecia estas coisas, dirão os autores da revista, e eu, então, direi que o público também gosta de ler nos jornais notícias de suicídio e os autores de Uma festa no Ó nunca se lembraram de pôr termo à vida, só para que o público se divertisse com a leitura de seu suicídio d'eles lá... ${ }^{77}$

Em seguida, foi apresentada a revista de Guedes e Cotó, O Recruta do 43. A história gira em torno da vinda de um caipira a São Paulo e seu encontro com o recruta do 43, que passará a lhe mostrar a cidade e seus tipos. Entretanto, a má fase da companhia, ou a responsabilidade, imputada ao gênero, pela "decadência do teatro brasileiro", não favoreceu avaliações positivas sobre a peça.

O Pirralho comenta que O Recruta do 43 seguia o "estafadíssimo chavão importado de Portugal". Apesar disso, o fato de não conter imoralidades, era um sinal de que podia ser assistido por toda família. Possuía tipos paulistas engraçados e bem apanhados; a música era alegre, embora pretensiosa; o coro das floristas "é bom que dói" e, como último elogio, o crítico, em tom humorístico, ressalta que são anuladas todas as disposições em contrário.

Os espetáculos em cartaz no teatro Boa Vista passaram a ser obrigatórios para o paulistano. Dentre os sucessos da Companhia Arruda figuravam O Recruta do 43, Uma festa no Ó, A Gran Via e as novidades O Picareta e A Pensão de D. Ana, de Danton Vampré. A Companhia Arruda firmou-se mesmo em São Paulo. Desde o seu surgimento, todos os anúncios relativos à montagem de revistas, nos periódicos pesquisados, são da companhia do festejado caipira.

Nos próximos anos, o grupo continuou a obter êxito. Em 1918, montou $A$ Divina Increnca, de Juó Bananére, pseudônimo de Alexandre Marcondes Machado, autor que seria reconhecido somente pela posteridade. Em janeiro, apresentou Sustenta a Nota, escrita em parceria por Danton Vampré e Euclydes de Andrade.

76 O Pirralho, número $243,1^{\circ}$ quinzena de setembro de 1917, ano VII. 
No artigo "Revistomania", de fevereiro de 1920, o articulista Claudio analisa a cena teatral do período, "atacada" por esse fenômeno ${ }^{78}$. Segundo o autor, os escritores teatrais, simpatizantes do gênero e responsáveis pelos cartazes dos nossos teatros, anunciavam a cada semana uma revista de "título espalhafatoso", tais como Tira a mão d'aí, Boi que estourou, A mulata encrencada, É de bam, bam bam e "outras imbecilidades do mesmo gênero". O crítico demonstrava o seu descontentamento com o sucesso do gênero revista, proclamando que as piadas de mau gosto, os efeitos de papelão pintado, o maxixe "de parafuso" e o caipira sempre perdido na capital tornavam a revista o gênero mais fácil de ser cultivado.

Em espírito cultiva-se geralmente o gênero fúnebre, em encenação reina as lantejoulas baratas e o papelão pintado e para os diálogos têm-se as piadas pornográficas. ${ }^{79}$

Assim sendo, prossegue o crítico, não é necessário ter talento, apenas uma resma de papel e muito topete. Os nossos escritores teatrais, segundo ele, não passavam de amanuenses de secretaria sem técnica teatral. Entretanto, poderiam pelo menos tentar um pouco mais de "bom gosto nos diálogos, um pouco mais de originalidade nos personagens e um pouco de interesse na urdidura; enfim pede-se aquilo que uma revista de ano nunca tem".

Claudio finaliza o texto clamando aos autores que retirem as revistas da cena teatral para a boa educação do gosto do nosso povo.

Carlos de Laet, colunista do Jornal do Brasil, julgava que a nossa literatura dramática era pobre de escritores teatrais. Após as tentativas de Gonçalves de Magalhães e de José de Alencar, só teria aparecido Artur Azevedo, e "ainda que desvairado da trilha boa e limpa, deu sinais de vida", mas no momento atual só havia o "silêncio de morte", pois o teatro agonizava. Quanto ao ator, esse raramente sabia comunicar beleza a um texto, quando o havia. As peças foram decaindo da opereta à revista. No seu entendimento, a invenção das revistas foi outro passo para a decadência do teatro brasileiro e, quando todos já haviam 
enjoado dessa "degeneração teatral", a situação só piorou com o regime de espetáculos por sessões.

O jornalista assim definiu a revista:

Um entrecho rudimentar põe em cena alguns compadres e certo grupo de figuras contemporâneas. Nada mais simples e para usar de usadíssimo plebeísmo, também nada mais besta... ${ }^{80}$

Leo Vaz possuía opinião diversa sobre a "decadência" do teatro. O escritor afirmava que o teatro nacional não estava decadente, muito menos ascendente, mas que andava no nível mediano das coisas. Para um país não muito evoluído como o nosso, seria normal que a arte teatral não acompanhasse a européia, já evoluída após anos de dedicação. E por isso não nos devíamos censurar. Na atualidade, porém, o teatro mesmo nos países civilizados já não tinha muita força e vivia como uma tradição inocente. Antes era arte, uma escola ou um oráculo, hoje, no entanto, não passava de excrescência.

Os empresários, portanto, nada tinham a fazer, a não ser transformar o teatro em "aparelho de fazer rir", produzindo peças que não valorizavam as idéias, mas que continham "ó máximo de cócegas necessário para sacudir as enxúndias abdominais das platéias numa gargalhada sacolejante".

Esse não era um fenômeno isolado, exclusivo do Brasil, mas de todos os países, informava. Para o crítico, o "amplo cenário de Ésquilo” retraiu-se com Moliére a apenas uma sala, e a tendência era "descer até o quiosque, para sumirse de vez como todas as coisas".

Por esses motivos, o teatro nacional, mesmo com algum esforço de Artur Azevedo, não era capaz de dar mais do que revistas, pois era tudo o que cabia dentro da nossa arte dramática, acreditava o escritor.

Esse artigo, reproduzido de O Estado de São Paulo e publicado na Revista do Brasi ${ }^{\beta 1}$, mostra-nos um crítico teatral bem pessimista e contraditório.

80 Revista do Brasil, número 25, janeiro de 1918, ano III, Vol. III, pp.98-99 81 Revista do Brasil, número 39, março de 1919, ano IV, Vol. X, pp. 364-366. 
É retomada muitas vezes nos artigos a idéia de que a revista só servia para fazer rir. Sendo assim, era condenada, pois estaria em desacordo com a função edificante e moralizadora que o teatro deveria privilegiar. Para cumprir seu papel de divulgador de boas ações, de formador do espírito de uma nação, tal como acreditavam os intelectuais da época, o teatro deveria banir as revistas da cena teatral. Afinal, esse gênero alimentava-se da pornografia e destinava-se somente ao público que ia ao teatro "desopilar o fígado", sem outro intuito, senão o de rir.

Coelho Neto, em um inquérito proposto pelo Correio Musical Brasileiro, responde à seguinte pergunta: Que pensa V.Exa. do momento atual do nosso teatro? Eis a resposta:

As primeiras investidas [no teatro] chegaram longe e os que as levaram foram homens de fé - desde Anchieta, o místico, até Agrário de Menezes com as ousadias trágicas; desde Martins Pena com as suas cenas populares, até Macedo com as suas figuras ainda coloniais; desde Alencar com a comédia de costumes e o famoso drama de propaganda até França Junior com as suas sátiras sem mordacidade; desde Artur Azevedo até...a decadência e entre os intérpretes um colosso: João Caetano.

Infelizmente, porém, esses heróis não tiveram quem Ihes continuasse a obra, nem, ao menos, quem defendesse o terreno que eles haviam conquistado e a espessura adensou-se de novo e o que nela surgiu foi isso que aí está, essa produção brejal, constituída de revistas e de obscenidades do mesmo padrão, que depravam o gosto, a moral e a gramática. ${ }^{82}$

O teatro de revista, que começara com tímidas aparições na cena paulistana, passou a ter mais destaque na segunda década do século XX. Os elogios ao novo gênero e a empolgação dos críticos com o surgimento de revisteiros, como Danton Vampré, cedem, aos poucos, espaço às avaliações negativas e às acusações de imoralidades e pornografias. Com o passar do tempo, as críticas tornaram-se mais freqüentes até o momento em que a revista foi apontada como uma das responsáveis pela decadência do teatro brasileiro.

82 Correio Musical Brasileiro, número 1, 1-15 de maio de 1921, pp.13-15. 
Essas características atribuídas ao gênero revista hoje podem ser repensadas. Analisando alguns textos da época, ou mesmo o resumo do que teria sido o enredo de uma revista, nota-se que o assunto priorizava sempre o elemento nacional, ou as cidades em que a peça se ambientava. O seu tema versava sobre situações cotidianas, momentos políticos ou alguma crise social. Além de ter recolhido temas no folclore brasileiro, na paisagem, na diversidade cultural e ter popularizado a música popular juntamente com o Carnaval, como ocorreu no Rio de Janeiro.

Miroel Silveira afirmou que a realidade não chegava ao teatro de revista, pois o mundo pintado em cena seria somente um mundo colorido e engraçado ${ }^{83}$. $\mathrm{O}$ historiador tem certa razão, afinal a realidade não chegava à cena com o objetivo de fazer refletir ou analisar criticamente a sociedade em que vivíamos. Embora ele não tenha considerado que o teatro de revista refletia o que interessava àquelas pessoas, naquele momento, as quais, talvez, quisessem "enxergar" o mundo de um jeito mais aprazível.

É justificável, pois, contrariar a tese de que não havia teatro nacional na época, uma vez que o assunto para a confecção do texto era retirado da nossa realidade. Afirmava Arlindo Leal:

Para a instrução que se adquire por preleções o homem do pensamento tem os livros; o da leitura, os jornais; o resto da sociedade, a cena. ${ }^{84}$

A citação de Arlindo Leal serve-nos de justificativa, mesmo sendo ele um crítico do teatro de revista. Se às pessoas que não têm acesso aos livros e jornais só resta a cena, a revista seria o meio mais eficiente para mostrar o que ocorria no país através de uma retrospectiva dos acontecimentos, ou uma re-visão dos fatos.

Além disso, pode-se refutar a idéia de que o gênero tenha sido uma das causas da decadência do nosso teatro; afinal a revista, aliada à opereta, manteve em atividade a cena teatral da época.

83 SILVEIRA, Miroel. A contribuição italiana ao teatro brasileiro. Op. cit. p.177. 
Outro ponto frágil da argumentação dos críticos e intelectuais do período estudado é o fato de a revista servir só para fazer rir. Era fazer rir, sim, mas das nossas mazelas sociais, e, ao rir disso, levar-nos à percepção da ironia e crítica do autor. Quanto mais rimos de uma situação que nos é familiar, mais ferina é a crítica, já que nos identificamos com o que está sendo mostrado. 


\subsection{Espetáculos de Variedades}

Nem só de revistas e operetas, vivia o teatro brasileiro do início do século $\mathrm{XX}$. Os nossos palcos também abrigavam na época diferentes números artísticos, aos quais se convencionou dar o nome de variedades. Esses espetáculos não tinham muita relação com a idéia de teatro que se tem hoje, pois não traziam atores, representando algum texto; no entanto foram associados à arte teatral.

Para definir teatralidade, Patrice Pavis cita Alain Girault:

O denominador comum a tudo o que se costuma chamar 'teatro' em nossa civilização é o seguinte: de um ponto de vista estático, um espaço de atuação (palco) e um espaço de onde se pode olhar (sala), um ator (gestual, voz) no palco e espectadores na sala. (Théâtre/Public n. 5 -6, junho de 1975, p. 14) ) $^{85}$

Portanto, havia nos números de variedades elementos suficientes para designá-los de teatro: o palco, que seria o espaço de atuação; a sala, o local da representação; e os artistas, que não sendo atores, possuíam outras habilidades.

Para se ter uma idéia do que compreendiam esses números, citamos uma nota da coluna teatral da Ilustração Paulista:

No Polytheama, atualmente encontra-se de tudo: chanteuses, gommeuses e sem gomma, à voix, à diction, excentriques et cominques, bailarinas espanholas, machiettistas, duettistas e cançonetistas italianas e internacionais, equilibristas, ilusionistas e Goytakysis com o seu célebre cão que fala. ${ }^{86}$

É importante destacar que consideramos variedades os números que trazem cantores, artistas com habilidades circenses, bailarinas, números com animais, com carros e motocicletas, números excêntricos, de mágica e outras curiosidades.

85 PAVIS, Patrice. Dicionário de Teatro. São Paulo, Perspectiva, 1999, p. 373 86 Ilustração Paulista, número 63, 30/03/1912. 
Os teatros que normalmente abrigavam esses espetáculos eram o Moulin Rouge, e o Polytheama, seguido pelo Casino, o "elegante music-hall da rua Onze de Julho".

$\mathrm{Na}$ primeira década do século, o teatro Moulin Rouge destacava-se na apresentação de número de variedades. As suas noite eram sempre animadas pelos números de cantoras, bailarinas francesas e espanholas, e atrações novas, que excitavam a curiosidade do público.

Em agosto de 1907, a trupe Montrose trouxe ao Moulin Rouge acrobacias modernas, cantores e ciclistas acrobáticos. No mês seguinte, a trupe cedeu o espaço à Companhia Marchetti que permaneceu até o começo de outubro, deixando o teatro para que lá estreasse uma outra trupe de variedades, "o gênero predileto do público paulista", conforme noticiado por $A$ Vida Moderna ${ }^{87}$.

Nessa temporada o número mais aguardado era o esmagamento do artista Marino por um automóvel de dois mil quilos. Ansiava-se também pelos espetáculos de luta romana.

O Polytheama foi inaugurado em fevereiro de 1892 como casa de espetáculos. Já na sua estréia, apresentaram-se artistas de todos os gêneros, com números de barra fixa, trapézio e contorcionismo. Transformado em teatro, meses depois, foi palco para a Companhia de Operetas, dirigida por Souza Bastos, que estreou com a opereta O Burro do Sr. Alcaide. Por diversas vezes, o prédio da Avenida São João, que abrigava o teatro, mudara seu estilo, ora funcionando como teatro, ora como café-concerto e casa de espetáculos. Por lá passaram grandes artistas como a portuguesa Ismênia dos Santos, a italiana Clara della Guardia e aquela que ganhou maior relevo entre as divas do teatro: a francesa Sara Bernhardt.

Em notícia publicada em 1915, a propósito do incêndio do teatro, O Pirralho afirmou que o teatro teve dias de glória, nos quais a elite paulistana disputava-lhe os ingressos com empenho e que, apesar de suas precárias condições, mantevese funcionando durante vinte e três anos. Sem perder o humor, Stiunirio Gama (provavelmente pseudônimo de algum crítico) descreveu o Polytheama:

87 A Vida Moderna, número 25, 15/10/1907, ano II, p. 16. 
Muito modesto, habitado por pulgas puro sangue e por uma interminável família de ratos, ria-se a bom rir do luxo asiático e do ouro espalhado pelo teto e pelas paredes do colosso do pontífice da arquitetura nacional, dizendo com os sérios botões: -Sou pobre, mas tenho acústica; o Scala, de Milão, não é mais bonito do que eu e no entanto é o preferido. ${ }^{88}$

Mesmo assim, o teatro vingou e recebeu grandes artistas: estrelas do teatro declamado e do teatro ligeiro, e artistas de variedades que ali fizeram sucesso, tais como o transformista Bertin e Miss Alegria, uma "formosa" atiradora mexicana.

Um incidente ocorrido no Casino durante a apresentação de um espetáculo de variedades suscitou um artigo na imprensa chamado "A ordem pública nos teatros" ${ }^{\prime 2}$. Nele, seu autor, Zupelin, solicitava que fosse punido todo indivíduo que perturbasse a ordem ou ofendesse a moral de alguém dentro dos teatros.

O episódio teve início com os costumeiros gracejos e excessos entre artistas e espectadores, conforme o articulista. Um artista, ofendido com um desses gracejos, logo após a descida do pano, saltou à platéia, passando por cima da cadeira do maestro, para exigir satisfações do espectador. Em meio à confusão, espectadores e artistas proferiam obscenidades em coro. Uma família do interior, escandalizada com o sucedido, retirou-se do local maldizendo a hora em que fora assistir a um espetáculo de variedades.

Esse tipo de situação, segundo Zupelin, dificilmente aconteceria em um país europeu, onde as pessoas respeitam as leis e onde são tomadas as devidas providências para punir o responsável por tal agressão.

Os teatros de variedades, que no momento predominavam em todos os cantos do mundo, de acordo com o crítico, eram considerados focos de libertinagem. Quando se falava em Moulin Rouge, Casino, raras eram as famílias que não se espantavam.

O nosso público era também responsável por não saber distinguir entre um bom ou mau artista. O que era bom, não era acolhido como merecia; o mau, era

88 O Pirralho, número 169, 09/01/1915, ano IV.

89 A Vida Moderna, número 90, 18 /06/1911, ano VI. 
coberto de aplausos, porque procurava atender o gosto do público, reproduzindo gracejos imorais e estúpidos. Assim sendo, dava ensejo para que se prosseguisse com esses espetáculos. Além disso, os expansivos espectadores também contribuíam com a imoralidade nos espetáculos. Os artistas acabavam sendo obrigados a satisfazer o gosto do público, e os estrangeiros, quando iam embora, diziam que aqui só fazia sucesso quem era imoral.

Lamentando, o crítico diz que nada podia ser feito para mudar tal quadro, uma vez que a polícia já habituara o povo a esses abusos, e os empresários do gênero só visavam ao lucro, sem ao menos se importarem com as leis do país e regulamentos teatrais.

Um italiano muito popular na época, o transformista Leopoldo Fregoli apresentou-se no Santana, em agosto de 1908. Assim o caracterizou, o colunista do periódico Vida Paulista:

.... homem relâmpago, que se metamorfoseia instantaneamente, mudando de hábito e de feição com a mesma rapidez com que certos e determinados patriotas...de barriga viram de casaca, a sabor das conveniências de ocasião. ${ }^{90}$

Notícias sobre números de variedades tornam-se mais freqüentes, nos periódicos pesquisados, a partir de 1911. Nesse ano, o teatro Santana recebeu o artista Eugenie Buffet e os concertos de Paderewski, além do trio Chaby-PhocaCollaço, apresentando monólogos e números cômicos.

No Casino, classificado como o "lugar mais alegre do São Paulo noturno", a "rapaziada foliona" e a "velhice gamenha" divertia-se ouvindo cançonetas. Os malabaristas faziam sucesso juntamente com os cantores "que se esgoelam a mais não poder".

Em fevereiro de 1912, o Polytheama transformou-se em café-concerto e trouxe a South American Tour. O teatro estava em uma boa fase e, em março, estreou Mr. Harry Lyndson, com a pantomima $O$ ladrão e a polícia e os seus cachorros equilibristas. O maior acontecimento, no entanto, é o trio Davies com o

90 Vida Paulista, número 130, 2 e 03/08/1908, ano III. 
círculo da morte.

A trupe South American Tour fazia grande sucesso e fez uma longa temporada. Mesmo assim, em abril, passou a disputar a atenção com a Companhia Arayama de equilibristas japoneses.

Enquanto isso, o Casino, o "teatro da moda", abrigo da sociedade paulistana, exibia as cantoras Lina Franci, Gloria Monti e Elvira Vanny. O festejado artista Fregolino apresentou, em maio, nesse teatro, suas comédias "mais ou menos elétricas", obtendo grande êxito.

A rotatividade de artistas nos teatros era grande. O Polytheama prometia de seis a oito estréias por semana, e o Casino de vinte a cinqüenta estréias, não especifica se por mês ou por semana, mas supõe-se que seja por mês.

Em junho, no velho barracão da Avenida São João, já trabalhavam outros artistas, o malabarista cômico José Chas e os acrobatas musicais Whinterley. No Casino faziam sucesso os musicais Los Alpinos e os excêntricos musicais Lima y Stise.

Em outubro, o Polytheama volta a "apanhar boas enchentes" com a trupe South American Tour, pois o público não cansava de apreciá-la. Também se apresentava no mesmo barracão uma trupe de anões.

Esses espetáculos faziam tanto sucesso que o teatro São José resolveu aderir à moda, e trouxe a transformista Fátima Miris, em fevereiro de 1913.

Os números faziam jus à classificação de variedades, isto é, eram tão variados, que anunciavam desde cantoras, ilusionistas, ventríloquos, até um cão que falava de verdade.

As notícias referentes ao Casino e ao Polytheama repetiam-se como refrões: "Enchentes e mais enchentes, sucessos e mais sucessos!", "Sempre muito concorridos os espetáculos destes teatros".

Outro tipo de divertimento surgiu em 1915 em meio às atrações voltadas ao público paulistano: os espetáculos mistos de cinema e teatro. João Felizardo atribuiu essa prática à decadência do cinematógrafo. Com a Primeira Guerra, o cinematógrafo entrara em decadência, devido à falta de novidades em filmes. Assim, fora obrigado a "dar as mãos" ao teatro para sobreviver. Entretanto, essa 
fórmula não estaria sendo bem usada pelos empresários, os quais não escolhiam bons números e não ofereciam vantagens aos artistas, levando à cena montagens de baixa qualidade.

Esses espetáculos realizavam-se da seguinte maneira: nos intervalos dos filmes, o telão subia e eram apresentados números de variedades, ao término desses, o filme recomeçava.

Segundo Neyde Veneziano, os espetáculos mistos de palco e tela fizeram mais sucesso em São Paulo que no Rio de Janeiro. Os números de variedades eram complementos teatrais do espetáculo cinematográfico, em que eram apresentados esquetes, números de cortinas e atrações diversas emprestadas do teatro de revista. Esses complementos teatrais, em breve, passariam a se chamar revuette ${ }^{91}$.

Carlos Leal, integrante da Companhia Galhardo, escreveu em parceria com Avelino de Souza a revuette O País do Sol, levada à cena em maio de 1915 no Palace Theatre. A crítica foi favorável à encenação:

Nota-se nela a emoção, o enternecimento do coração dos autores ante o espetáculo sempre belo e sempre novo dessa bela e sempre amada terra portuguesa. A essa emoção dos autores do diálogo e versos coube o maestro Luiz Júnior corresponder, compondo uma música belíssima, leve e agradável. ${ }^{92}$

Mereceram elogios o ator Gomes, encarregado da mise-en-scene, os compères Philomena Lima e Carlos Leal, Irene Gomes - "a bela tricana" - e Antonio Gomes, "o cavador".

A empresa Fortunato de Andrade \& Irmão proporcionava, nesse mesmo mês, "esplêndidas soirrées", no teatro São Paulo. No local, eram apresentados filmes "escolhidos caprichosamente", acompanhados de orquestra e números de variedades, dos quais participavam Lola Salgado, uma festejada cantora italiana e a cantora espanhola Carmem Ferrer.

91 VENEZIANO, Neyde. De pernas para o ar: O Teatro de Revista em São Paulo. São Paulo: Imprensa Oficial, 2006, p. 131. 92 O Pirralho, número 189, 28/05/1915. 
O grupo amador Grêmio Dramático Santa Cecília também tornou-se adepto dos números de variedades. No programa de sua récita, realizada no dia 4 de dezembro de 1915, constavam três partes, sendo a primeira e a terceira compostas de variedades, e a segunda de uma "espirituosa" comédia. Nos intervalos dos números, a orquestra do grêmio, dirigida pelo maestro Otaciano Delgado, executava "peças escolhidas com fino gosto".

O público, sempre ansioso por novidades, corria aos teatros quando alguma estréia anunciava-se. Em janeiro de 1916, o destaque eram os números de ciclistas e cowboys trazidos por The Buffalo \& Co, para o Casino Antarctica. Outro número que fazia sucesso nesse "artístico barracão" era Uma noite num caféconcerto, bom e engraçado, na opinião dos críticos. No entanto, seria melhor, se não fosse pelo casal de italianos, que se pretendia engraçado, mas punha-se a gritar, dizer "asneiras" e a pular no palco, o que irritava até o "mais pacato burguês". 93

O Casino Antarctica também oferecia os números mistos de palco e tela. Em fevereiro de 1916, entremeado por números de café-concerto exibiu-se uma fita de guerra com "réclames de autenticidade". Aproveitando o mês de carnaval, a empresa administradora do teatro organizou grandiosos bailes, sem deixar, porém, de apresentar os espetáculos de variedades.

Além dos bailes, exibem-se lá todas as gomeuses diseuses e excentriques da terra e dos estrangeiro. ${ }^{94}$

Café-concerto era o nome dado ao lugar onde se apresentavam espetáculos variados, mas também servia para designar um gênero de diversão que incluía números de orquestra, cançonetistas, bailarinas, excêntricos, ciclistas e cômicos. ${ }^{95}$

A Companhia de Christiano de Souza foi outra a se apresentar no Casino, em maio de 1916, com a revuette de costumes paulistas A Posse do Presidente,

93 O Queixoso, número 3, 13/01/1916, ano I. 94 O Queixoso, número 6, 25/02/1916, ano I. 95 VENEZIANO, Neyde. De pernas para o ar, Op. cit. , p. 76. 
que foi um enorme sucesso ${ }^{96}$. Essa revuette, segundo Neyde Veneziano, era uma revista de Luís Rocha e Antônio Silva, com músicas de Luís Moreira, Raul Martins e Verdi de Carvalho. Seu assunto referia-se a Venceslau Brás, o "seu Lalau", como era conhecido no teatro de revista ${ }^{97}$.

Antes mesmo que os números de variedades vivessem seu apogeu, entre os anos de 1911 a 1915, Antonio Piccarolo já se manifestara nos periódicos a respeito do gênero. Em artigo, publicado em O Echo, em junho de 1910, ele analisa a construção dos teatros municipais do Rio de Janeiro e São Paulo. De acordo com o professor, esses teatros não correspondiam às reais necessidades e tendências dos tempos modernos. O público freqüentador de teatro não era mais constituído pelas classes aristocráticas, ao contrário, era a grande massa, formada pela burguesia enriquecida no comércio, os aspirantes a cargos políticos, e o proletariado. Assim sendo, a escolha arquitetônica para a construção desses teatros excluiu desse local a grande massa, que preferia o simples divertimento de uma opereta ou cançoneta de café-cantante à "verdadeira arte", a arte que é escola de moral e de bons costumes.

Em uma hierarquia dos gêneros teatrais, portanto, os números de variedades estariam ao lado da opereta, apontada, diversas vezes, como uma das responsáveis pela decadência do teatro nacional.

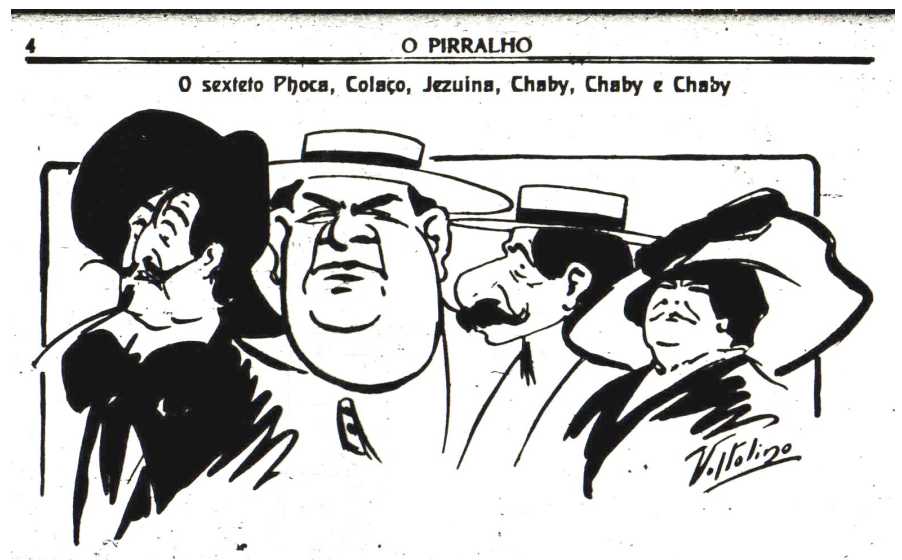

(O Pirralho, número 08, 30/09/1911, ano I)

96 O Furão, número 53, 13/05/1916, ano Il, p. 1.

97 VENEZIANO, Neyde. Op. cit., p.133. 


\subsection{A presença estrangeira}

Viveremos sempre, em matéria e de arte e literatura, nesse período colonial em que o estrangeiro adventício nos domina e explora, como o conquistador primitivo seduzia os morubixabas indígenas com as suas bugigangas de pacotilha? ${ }^{98}$

(Paulo Prado)

Carlos de Laet afirmou, na Revista do Brasil, que o teatro nacional, assim como o equilíbrio orçamentário e a verdade eleitoral, constituía uma das utopias em nosso país. ${ }^{99}$

Desiludidos com o panorama teatral do momento, críticos e intelectuais repetiam o bordão da inexistência do teatro nacional ou de sua decadência. Alimentada por vários fatores, essa "crise" dispunha de mais um responsável: a presença das companhias estrangeiras em solo brasileiro. O público admirador de Lucien Guitry, Félix Huguenet, Tina di Lorenzo e Ettore Vitale desconsiderava os artistas nacionais. A citação abaixo mostra o descontentamento dos intelectuais brasileiros com essa situação:

No Brasil, o rótulo em língua estranha vale sempre mais que ...o medicamento. ${ }^{100}$

O crítico Fly, do Diário de Minas, considerava o artista nacional uma vítima indefesa dos rivais estrangeiros. Àquele seriam negadas boas oportunidades de reconhecimento, uma vez que a publicidade dada aos estrangeiros ofuscava 0 mérito dos nossos artistas ${ }^{101}$.

O ano de 1907, por exemplo, foi caracterizado como "duma fecundidade artística notávep'102. Certamente, não para os brasileiros, sendo que o comentário anterior baseou-se nas temporadas européias. Em 1907, visitaram-nos a Companhia Vitale, Companhia Christiano de Souza, Companhia dos atores Salvini

98 PRADO, Paulo. Paulística etc. São Paulo, Companhia das Letras, 2004, p. 306.

99 Revista do Brasil, número 25, janeiro de 1918, ano III, Vol. VII, pp. 98-99.

100 Éden revista/ Revista Theatral e Cinematográfica, número 12, ano III, março de 1915.

101 Revista do Brasil, número 46, outubro de 1919, ano IX, Volume XII, p. 281.

102 A Vida Moderna, números 29 e 30, ano II, 25/12/1907. 
e Bolognesi, Companhia Marchetti, o artista Frank Brown, a trupe Montrose, uma Companhia Lírica Italiana, Companhia Cittá di Milano, e a respeitada atriz Eleonora Duse.

$\mathrm{Na}$ estréia da Companhia Marchetti, em setembro desse ano, o Moulin Rouge recebeu um numeroso público.

O público paulista tem gosto e ama a arte dramática, principalmente no gênero adotado por essa rapaziada alegre e folgazã...As peças até hoje levadas por esta companhia, representam o que pode haver de mais original e novo no gênero cômico que é a sua especialidade. ${ }^{103}$

A Companhia Vitale chegou ao Brasil em junho de 1907 e, conforme os registros, ficou aproximadamente um ano em nosso país. A Vida Moderna informanos que os espetáculos do grupo eram bastante concorridos e que não faltavam aplausos aos artistas da companhia. Entre esses os que mereceram maior destaque foram Giselda e Morosini, Inês Imbimbo e o cômico Ítalo Bertini ${ }^{104}$. Devido ao sucesso da temporada, a Companhia voltou em outras ocasiões ao Brasil.

Em julho de 1908, estreou no Santana Tina di Lorenzo, a "Rainha da Arte Dramática", sob a direção de Luigi Carini. O Palco Ilustrado fez uma relação das peças que compunham o repertório da atriz: II Ladro, La Rafale, de Bernstein; Adriana Lecouvreur, de Scribe e Legouvé; Battaglia di Dame, de Scribe; La Doulourese, Gli Amanti, de Donnay; Pamela nubile, Locandiera, Glinnamorati, de Goldoni; Moglie Decorativa, de De Curel; Heurese, de Hennequim; Seconda Moglie, Santarellina, de Pinero; Teodora, Andreina, Fedora, Divorziano, Doral Fernandal Marcellal Odette, Pátria, Madame Sans Gene, de Sardou; Come le foglie, Reza a discrezione, Tristi amori, de Giacosa; Avversario, de Capus; Magda, de Suderman; Cantico dei Cantici, Figlia di Jeffe, de Cavallotti; Cavalleria Rusticana, de Verga; Casa di Bambola, de Ibsen; Romanticismo, II Re Burlone, Trilogia di Dorina, de Rocetta; Gelosa, de Bissou; Giulietta e Romeo, de Shakespeare; Maternita, de Bracco; Monda della noia, de Pailleron; Dionísia, 
Signora dalle Camelie, Francillón, Principessa Giorgio, Demi monde, Staniera, de Dumas; Frou- Frou, de Meilhac et Halévy; Maria Antonietta, de Giacometti; Parigina, de Becque; Musotte, de Maupassant; Samaritana, de Rostand; Bonheur, Mesdames, de Di Croiset; Vers l'amour, de Gandillot; Zazá, de Berton e Simon; Saffo, de Daudet e Belot; Fouchambault, de Augier; In Automobile, Duchessina, de Testoni; Guerra in tempo di pace- Mozer e Schonton ${ }^{105}$.

A lista é extensa, mas de suma importância para considerarmos o gosto e a tendência da época. Ao lado de autores de melodrama como Hennequim figuravam autores como Shakespeare e lbsen, representantes de um teatro mais denso.

A atriz também apresentou $O$ Dote, de Artur Azevedo, interpretando a personagem principal. Segundo o cronista de $A$ Vida Paulista, sua interpretação valorizou a peça, considerada inferior a Almanjarra e ao Badejo ${ }^{106}$. Enquanto a atriz apresentava-se no Santana, fazia sucesso no Polytheama a Companhia Lahoz, e no Colombo, a Companhia Dramática Portuguesa Gomes da Silva.

Antes da vinda da "Rainha da Arte dramática", visitaram-nos a aclamada atriz Sarah Bernhardt (1886, 1893 e 1905), Suzanne Desprès (1906, 1916), Eleonora Duse $(1887,1907)$. Esta última, em sua segunda vinda ao Brasil, também trouxe em seu repertório uma peça de Ibsen, Hedda Gabler. ${ }^{107}$

Em 1911 retorna a São Paulo a Companhia Vitale. Apresentam-se ainda a Companhia Gattini-Angellini, a Companhia Dramática Portuguesa Alves da Silva, Cittá di Napoli, Companhia do português José Ricardo, Companhia francesa da atriz Nina Sanzi, Companhia francesa de Chatelet de Paris, a trupe Mascagni, Companhia Galhardo, Titta Ruffo e a Companhia Renzi-Gabrielli.

A Companhia Vitale inicia o ano de 1912 no Polytheama, enquanto estréia no São José a Companhia Marchetti, apresentando, entre outras, a peça $A$ Viúva Alegre. O público possuía também a alternativa de prestigiar a Companhia Lahoz, a Companhia italiana Rotoli-Billoro, e a Companhia Juvenil italiana.

105 O Palco llustrado, número 1 , junho de 1908.

106 Vida Paulista, número 127, ano III, 12 e 13 de julho de 1908.

107 MAGALDI, Sábato \& VARGAS, Maria Thereza. Cem anos de teatro em São Paulo (1875-1974). Op. cit., p. 44. 
Clara Della Guardia chega ao Brasil em agosto, e estréia no Municipal com a Rosmunda, de Sam Benneli. Em A Dama das Camélias recebeu elogios da crítica de O Pirralho:

Na Dama das Camélias ela compôs muito bem o tipo daquela mundana apaixonada e chorosa. $^{108}$

O crítico acrescentou que, como o público preferia o cinematógrafo, ou as operetas A Viúva Alegre e A Casta Suzana ao teatro declamado, o Municipal só não ficara "às moscas" por causa de Clara Della Guardia.

Outro italiano aclamado pela crítica visitou-nos em 1912. Ermete Novelli e a Companhia Dramática Italiana apresentaram no Municipal, em setembro, a peça Papá Lebonnard, de Jean Aicard. Desfrutando da boa fase do teatro, direcionada às companhias estrangeiras, a Companhia Sconamiglio-Caramba estreou no São José, com O Cigano Barão, de Strauss.

O destaque em 1913 fica por conta novamente da Companhia Lahoz, da Companhia Vitale, e Ermete Novelli.

Marcus Priscus, de $O$ Pirralho, escreveu um artigo só para elogiar o ator italiano:

Novelli estreou. Não deixei de ir vê-lo. Fui e amei-o mais do que já o amava. Ele é destes seres privilegiados, que a gente cada vez mais admira, admiração que cresce sempre, cada vez mais, até que num crescendo assombroso nos leva à veneração. ${ }^{109}$

A novidade do ano é a Companhia Adelina Abranches, no Palace Theatre, também aprovada pela imprensa:

Tudo é perfeito no trabalho de Adelina Abranches. ${ }^{110}$

108 O Pirralho, número 55, 24 de agosto de 1912.

109 O Pirralho, número 92, 24/05/1913.

110 O Pirralho, número 97, 28/06/1913. 
Tina di Lorenzo retorna aos palcos do Municipal em julho de 1913. Após sua temporada, esse teatro recebe o ator francês Félix Huguénet.

Não só artistas franceses, portugueses e italianos exibiram-se em São Paulo nesse ano, mas também a Companhia Espanhola de Dom Pablo Lopez, a Companhia Alemã Tuscher e uma companhia israelita de variedades.

Quanto ao ano de 1914, somente três periódicos foram encontrados: 0 Pirralho, A Ronda e a Revista Theatral/ Teatro, Arte, Sport...e o que for. Observase por essas revistas que poucas companhias estrangeiras aqui estiveram nesse ano. Destacam-se a Companhia Vitale e a Companhia Sconamiglio-Caramba.

Abadie Faria Rosa e o ator João Barbosa concordam que a guerra favoreceu o teatro brasileiro ao dificultar a vinda de companhias européias. No entanto, para o primeiro, fazia-se necessário criar um ambiente propício ao teatro nacional, caso contrário continuaríamos à mercê dos estrangeiros. João Barbosa apostava em uma subvenção oficial para a valorização do teatro, assim como o havia para a música e para a pintura, segundo afirmava. Contudo, era fundamental o emprego adequado desse dinheiro, uma vez que o município gastara mais de quatorze mil contos na construção do teatro Municipal, e este só servira aos elencos estrangeiros, que lá representavam suas peças e cantavam suas óperas; aos atores brasileiros só restavam os simples barracões. ${ }^{111}$

O teatro Municipal, apelidado de "feira de vaidades" pelo cronista S. de N. ${ }^{112}$, era freqüentado principalmente pela elite paulistana, ávida por prestigiar artistas estrangeiros. A sua construção foi um evento muito aguardado pelos amantes do teatro e das artes em geral porque se esperava que esse investimento revertesse a situação do teatro nacional. Entretanto, logo no início, surgiu uma polêmica envolvendo o artista que inauguraria o teatro. Após discussões, decidiu-se pela Companhia do barítono Titta Ruffo, com Hamlet, de Ambroise Thomas. Essa escolha criou desavenças na Câmara Municipal, e Alcântara Machado, o porta-voz do grupo, enviou em protesto uma representação ao Centro de Ciências e Letras de Campinas, e o resultado foi a representação da protofonia de $O$ Guarani,

111 Correio Musical Brasileiro, número 1, 1-15 de maio de 1921, ano I, pp.13 a 15. 
precedendo Hamlet. Além de Hamlet, a Companhia trouxe em seu repertório Rigoletto, Fígaro, O Barbeiro de Sevilha, Tristão e Isolda, Manon Lescault e Madame Butterfly.

O Pirralho noticia, em forma de brincadeira, que o teatro seria inaugurado com um "impagável poema tragi-cômico" de colaboração diversa intitulado La Figlia del Caramurú.

La Figlia del Caramurú é uma obra de mocidade de dois membros da comissão do Municipal em companhia do Dr. J. J. e de mais um italianinho que verteu a salada dantescamente. ${ }^{113}$

Sem abandonar o estilo satírico, $O$ Pirralho, referindo-se ao teatro como "Elefante branco", divulgou a transformação do local em casa de chá. A confirmação dessa notícia sai na edição de 11 de novembro: "o Municipal está fechado como teatro e aberto como casa de chá"114. Mário Mariz da Ilustração Paulista é outro a mencionar o funcionamento do teatro como casa de chá115. Provavelmente, essa função Ihe foi atribuída devido à forma como o Municipal vinha sendo administrado, e do período em que permaneceu fechado.

Em São Paulo Futuro há uma cena satirizando essa situação:

Gaudencio - Quem é aquele que vem lá vestido de rei do cangaço?

B. Verde - Aquele é o Teatro Municipal. Um sujeito que por ser tão enfastuado (sic) é que o público embirra com ele e não freqüenta. Só serve para tomar chá.

Gaudencio - Então já virou botequim?!

B. Verde - O ponto de automóveis. Ah! Meu amigo! Nunca passará disso "Fere, fere, tuti, latim, fere, opsim" (sic). Ele é, tem sido, e será sempre a mesma coisa.

Municipal (entrando) - Eu já não sou casa de espetáculos.

Gaudencio - Então o que é madama?

Municipal - Um grande botequim de tomar chá. (canta)

Quanto desespero amargo e triste

113 O Pirralho, número 3, 26/08/1911, p. 11.

114 O Pirralho, número 14, 11/11/1911, p. 10.

115 llustração Paulista, número 48, 16/12/1911, ano I. 
Na minha alma vivo a soluçar

Quanta esperança verde, quanta esperança

Tive de perder e de chorar

O meu claro sonho de sucesso

Ah! Jamais, jamais vi realizado

E se nada espero do futuro

Já não volto a olhar para o passado

Todos - És um infeliz. Oh! Municipal

Toda essa riqueza. Para nada vale.

Toda essa beleza. Para nada vale.

Municipal - (fala) Eu sou o templo das artes, onde se falam todas as línguas menos a minha, o Francês, o Inglês, o Grooulandes (sic), o Patagonês, e ainda espero ser invadida por uma troupe de Memelik.

Gaudencio - Ué! O Memelik vem aí com a companhia dos cavalinho (sic).

B. Verde - E são só dessas lingüísticas e melodramáticas que nos tens a mostrar?

Municipal - Não! tenho também conferências, concertos e chás com torradas, guarda-chuvas, monsieur.

Gaudencio - Rapadura. Garapa. Batata o Forno (sic).

Municipal - (recita) Um botequim bem servido

Soirées dançantes a valer

Teatro Lírico escolhido

Mas tudo isso para inglês ver.

Todo esse trecho da peça foi riscado pela censura em 1931.

A organização de um sindicato lírico para trazer companhias de ópera ao Municipal foi a solução defendida para a sua reabertura. Em julho de 1912, após o sindicato enfrentar protestos, aconteceu a estréia de uma companhia francesa com a peça La griffe, de Henry Bernstein. Anunciava-se também a Companhia lírica italiana La Teatral, do teatro Constanzi, de Roma, com destaque para a atriz Rozina Storchio, com Rigoletto.

Em 1915, Félix Huguenet estreou no Municipal. 
A estréia foi promissora, tendo o lindo teatro municipal se locupletado, com o que S. Paulo tem de mais fino e inteligente e elegante. ${ }^{116}$

Nesse mesmo ano estiveram também em São Paulo a Companhia Galhardo, a Companhia Adelina Abranches-Alexandre de Azevedo e a do barítono Titta Ruffo.

Acerca das temporadas estrangeiras, ironizou um crítico de O Pirralho:

Não se compreende o Municipal sem companhia estrangeira, pois não representa ele a cultura artística nacional ${ }^{117}$

A principal atração de 1916 foi o ator Lucien Guitry. Sua temporada no Municipal foi um sucesso. Um mês antes de sua chegada, o colunista Paulo de S. Paulo, de O Echo, escreveu um artigo destacando as qualidades do ator.

Aí vem ele como pontífice máximo dessa cátedra donde partiram todas as lições e todas as máximas que a humanidade tem reclamado. $\mathrm{E}$ o teatro - um tablado chamarreado de luzes coruscantes - será o frio bisturi que esvurnará a cáncera que dorme equimosada nas dobras dessas almas que o egoísmo dos nossos dias jogou à sarjeta imunda; será, também, o regenerador das frivolidades nocivas que enregelam os espíritos da nossa mocidade, sustando-a para o vôo nervoso do sonho e da arte. $^{118}$

Em um rompante de sentimentos, o cronista utiliza todo o seu vocabulário para expressar sua admiração pelo ator. E espera que as pessoas acorram ao Municipal, pois lá encontrarão uma "fortaleza para a alma", como afirma.

Em 6 de agosto de 1916, chega finalmente a São Paulo Lucien Guitry.

A Revista do Brasil registrou a temporada do ator francês e ressaltou que do repertório da companhia constavam, além das peças familiares, duas novidades:

116 O Pirralho, número 197, 24/07/1915, ano IV 117 O Pirralho, número 189, 28/05/1915, ano IV. 118 O Echo, número 2, agosto de 1916, ano XV. 
Pétard, de Henri Lavedan; e Miette, de Dario Nicodemi. A respeito dessas peças, escreveu o crítico:

Pétard é uma caricatura do "parvenu" grosseiro, egoísta, espalhafatoso, grotesco e ridículo, que a nossa sociedade procriou e Miette, uma delicada fantasia sentimental, escrita com espírito e disposta com habilidade. ${ }^{119}$

Miette foi o maior triunfo da companhia Guitry nessa temporada. De acordo com a crítica, as companhias francesas que nos visitavam alcançavam maior êxito quando não traziam o adultério como tema de suas peças, pois o público já estava cansado desse "teatro mórbido, onde só se estudam taras morais e onde só se exibem tipos depravados". O mesmo ocorrera com a companhia Huguenet no ano anterior. Segundo o artigo, a representação de Georgette Lemmeunier fora um sucesso por tratar de um episódio de amor conjugal.

Lucien Guitry teve seu melhor momento interpretando papéis escritos por Bernstein, curiosamente os que deixaram o público mais indiferente. ${ }^{120}$

Tobias Monteiro posiciona-se contra o repertório das companhias francesas, defendendo que os adultérios do teatro francês interessam muito menos ao nosso público do que um episódio de nossa vida eleitoral. Do teatro estrangeiro já bastava aquele apresentado no teatro Municipal à alta sociedade paulista. Isso não significava, porém, que ele devesse ser eliminado, afinal tinha sua utilidade: ensinar aos nossos escritores lições de técnicas, e aos atores, a arte de representar. $O$ crítico expõe a tese de que a literatura teatral de um país não pode isolar-se em suas fronteiras. Haveria um elemento universal na arte teatral comum a todos os povos, o que Tobias Monteiro chamou de "molde comum". Desse modo, os escritores brasileiros deveriam colocar nesse "molde comum" um conteúdo nosso, para que o pudéssemos chamar de teatro brasileiro. O que se escrevia, conforme seus apontamentos, era um teatro vazio, teatro de empréstimo ou de "franca rapinagem". ${ }^{121}$

119 Revista do Brasil, agosto de 1916, número 8, Volume II, ano I p. 388. 
A chegada da Companhia Lírica do Teatro Colon, de Buenos Aires, prometida pelo empresário Walter Mochi para o dia 18 de agosto, era aguardada com ansiedade. Conforme a coluna Theatros, de setembro de 1916, do periódico $O$ Echo, no momento, além de Lucien Guitry e da Companhia Lírica, apresentavamse na cidade a transformista Fátima Miris, trazida por José Loureiro, e a Companhia Vitale.

O teatro Municipal, em outubro, continuou a ceder seu palco para as companhias trazidas por Walter Mochi, "a quem São Paulo, em matéria de teatro, tudo deve", segundo o colunista de O Echo. ${ }^{122}$

O Municipal apresenta todas as noites o aspecto feérico de uma casa magnificamente bela, onde, numa doce mistura dos "habits" e dos lindos "decottés", passeia suas elegâncias a "elite" que ama e aprecia a música. ${ }^{123}$

Os comentários do colunista de $O$ Echo são reveladores, na medida em que nos informam sobre o público freqüentador das temporadas estrangeiras e sua preferência pelo teatro europeu, sobretudo francês. Essa situação indica a preocupação da elite brasileira em se enquadrar nos moldes europeus, considerados civilizados.

O fato de o Municipal ser ocupado somente por companhias estrangeiras é alvo da crítica de $O$ Pirralho. $O$ periódico traz o seguinte diálogo satirizando a situação:

No teatro Municipal. Palestram diversos cavalheiros da nossa melhor sociedade.

-Acho que estão barateando o nosso Municipal.

-Por quê?

- Isto só devia aceitar companhias líricas.

-É verdade

-Agora já vêm as companhias dramáticas e até uma de operetas já se anuncia.

-Uma vergonha!

122 O Echo, outubro de 1916, número IV, ano XV.

123 Idem, ibidem. 
- Até a "Caipirinha" veio parar aqui com caipiras descalços. É uma falta de consideração.

-Está visto. Já que vinham representar no Municipal porque não fazem os caipiras de botinas ou botas.

-É verdade, que desaforo! ${ }^{124}$

O teatro São José era outro a acolher as companhias estrangeiras. A portuguesa Aura Abranches, por exemplo, levou um público numeroso a esse teatro e foi muito aplaudida pelo público paulistano, admirado com o talento da atriz:

E como era bom ouvir-se a delicada "troupe" lusitana! Peças, na maioria francesas, proporcionou-nos a distinta companhia. E uma ficou, perenemente, gravada nos nossos corações - "Le Lys" - de Wolff, um romance escrito entre uma lágrima quente e o esgalçar de um sorriso inocente. ${ }^{125}$

Aura Abranches apresentou-se diversas vezes no Brasil, e sempre foi bem recebida pelo público e pela crítica. No ano de 1921, o Correio Musical Brasileiro noticiou a expectativa do público com a vinda da atriz, que estrearia com a peça $O$ grande amor, de Dario Nicodemi. O dramaturgo também planejava vir ao Brasil com uma trupe de novos artistas italianos, mas, devido à baixa do câmbio, cancelou sua visita. A essa informação o colunista comentou:

Temos destarte que renunciar, forçados pelas circunstâncias, a alguns momentos de arte verdadeira...Paciência! ${ }^{126}$

A observação acima reforça a tese de supervalorização do teatro estrangeiro em detrimento do nacional.

A Vida Moderna exibe uma nota satírica contando que no Boa Vista exibiase um prestidigitador e ilusionista que se dizia mexicano, mas na verdade era

124 O Pirralho, número 238, 20/05/1917, ano VI.

125 O Echo, número IV, outubro de 1916, ano XV.

126 Correio Musical Brasileiro, número 3, 1-15 de junho de 1921, ano I, p. 9. 
brasileiro "da gema". Descoberta sua nacionalidade, o artista defendeu-se com esta explicação, dada a um compatriota seu:

-Eu sou brasileiro, mas como em nosso país só se dá atenção ao que vem de fora, tomei a deliberação de me proclamar mexicano. Cá vou - não é trocadilho arranjando a minha vida. ${ }^{127}$

Em 1921, a temporada oficial do Teatro Municipal trouxe a Companhia do Athenée de Paris. A estréia se deu com a peça Le retour. Faziam parte do repertório: Le secret, L'air de Paris, Monsieur Beverely, Poliche, Copains, Un homme en habit, Amour quand tu nous tiens, La 13ㄹ. classe, La belle aventure, Château historique. Para a despedida da Companhia do Sr. Rozemberg reservouse a peça Le couché de la mariée, cujos entreatos foram preenchidos com os monólogos La classe e Une journée perdue, interpretados pelo próprio Rozemberg. ${ }^{128}$

Nos primeiros anos do século, Arlindo Leal já afirmara que não cuidávamos de nacionalizar o teatro, pelo contrário, importávamos atores e autores. Dessa maneira, nos palcos brasileiros, predominava o alheio, hábitos, emoções, sentimentos, costumes que não nos pertenciam. O dramaturgo compartilhava da opinião vigente de que o teatro seria instrumento para a educação de um povo, escola onde se estudam os costumes de uma nação; mas bradava que essa finalidade não seria alcançada, pois as companhias estrangeiras dominavam os palcos nacionais.

Aos autores que se dedicavam à carreira teatral, o autor de $O$ Boato recomendou tomar como modelo a escola dos comediógrafos Martins Pena e França Júnior, pois eles haviam nacionalizado a cena brasileira, transpondo para o palco nossos usos e costumes. Martins Pena, além disso, teve o mérito de criar a verdadeira escola nacional, exemplo de moral no teatro em tempos conturbados, e que haveria de triunfar, para que a arte nacional renascesse ${ }^{129}$.

127 A Vida Moderna, número 371, 27/11/1919, ano XV. 128 Correio Musical Brasileiro, número 3, 1ำ-15 de junho de 1921, ano I, p. 7. 129 Íris, 1905, número 1, Vol I, pp. 19 a 21. 
No artigo de 1906, o dramaturgo também refletiu sobre a influência estrangeira no teatro brasileiro. Ele apontou como solução para esse problema a criação de um Conservatório Dramático e Musical, cuja direção deveria ser entregue a pessoas que realmente contribuíssem para a formação de uma sociedade. Pessoas íntegras, cujo amor à arte superasse o amor à glória pessoal, "a verdadeiros mestres que possam contribuir para o progresso e engrandecimento moral e intelectual do povo" ${ }^{130}$.

Segundo ele, a arte se fazia tão necessária ao ser humano quanto o alimento. Portanto, era imprescindível o desenvolvimento e o estímulo do gosto pelo teatro nacional, uma vez que - ele recorre novamente à questão - o teatro era escola de moral e de bons costumes. Exceto pelo artigo $O$ realismo no teatro, em que Arlindo Leal discute a aceitação de Émile Zola na literatura teatral ${ }^{131}$, os demais, se não versam especificamente sobre a função moral do teatro, ao menos iniciam essa discussão.

A influência exercida pelo teatro estrangeiro não é uma discussão exclusiva do início do século XX. Múcio da Paixão esclarece que no século XVII o teatro português deixou-se influenciar tanto pelo espanhol que essa influência veio abarcar aqui no Brasil ${ }^{132}$. A partir de então o teatro sempre viveu em crise porque 0 público só valorizava o elemento estrangeiro, e os atores nacionais tinham que a ele recorrer para garantir sua sobrevivência. O produto nacional passou a ser desmerecido simplesmente porque ser nacional. Essa situação encontrou terreno fértil no início do século XX, num momento em que a elite buscava firmar-se como classe dominante, e para tal buscava inspiração nos modelos europeus.

Jairo de Góes foi outro crítico a concluir que a literatura dramática nacional não tinha seu valor reconhecido no seu próprio país, onde, de acordo com suas palavras, só as celebridades importadas, rotuladas de gênios, recebiam aplausos de uma platéia esnobe, interessada somente em trabalhos que trouxessem o rótulo de obras-primas ${ }^{133}$.

130 Íris, 1906, Vol I, pp. 148-150.

131 Íris, Vol I, 1905, pp. 86-89.

132 PAIXÃO, Múcio da. O teatro no Brasil. Op. cit., p.21.

133 Éden Éden revista/ Revista theatral e cinematográfica, número 12, ano III, março de 1915. 
A carência de dramaturgos brasileiros servira de assunto anos antes para $O$ Pirralho. No artigo Os Ratos (Publicação d'inquérito à vida brasileira), o periódico, com seu habitual histrionismo, relatou a criação de um prêmio de cinco contos, oferecido pelo governo municipal, para "indenizar das massadas da gestação literária" a pessoa que se dispusesse a escrever uma peça teatral, a ser representada por uma companhia nacional. Todavia, $O$ Pirralho julgou desmoralizante o caráter artístico da proposta, uma vez que o prêmio seria a recompensa em dinheiro.

Ironicamente, o colunista reconhece a sua má fé e afirma não possuir o engenho necessário a tal empreitada, pois se o tivesse poderia ter esperanças de "embolsar" a quantia prometida. Além disso, admite que essas insinuações não são suficientes para ridicularizar o concurso. Sendo assim, só lhe resta chamar a atenção dos que necessitam de cinco contos e quiçá despertar uma vocação. Ele confessa que suas intenções não são ruins, e que a sua má fé visa a "apenas deprimir o teatro nacional" contra o qual nutre um ódio mortal.

Após essa explanação, o crítico deseja que o dinheiro seja destinado a alguém que realmente necessite dele, como, por exemplo, um amigo seu que lamentara certo dia a "falta de cobres". Lembrando-se disso, aconselha seu amigo a escrever para o teatro, mesmo que nunca o tenha feito.

-Mas eu nunca tentei escrever para teatro.

-Esta é boa, Sardou, antes do seu primeiro sucesso, fez baboseiras; e baboseiras muitas espalhou pelo mundo após a conquista da celebridade. ${ }^{134}$

Conforme prosseguiu O Pirralho, a peça não corria o risco de ser rejeitada, mesmo que, de acordo com suas palavras, fosse "uma droga". Isso poderia acontecer se estivéssemos em qualquer país culto, na França, por exemplo. Mas, no Brasil, uma vez que se pretendia proteger a arte nacional, a comissão julgadora seria obrigada a aceitar qualquer "xaropada". A concorrência também não seria problema a seu amigo, afinal não tínhamos dramaturgos nem comediógrafos.

134 O Pirralho, número 76, 01/02/1913. 
Como recompensa pelos conselhos, o colunista espera que seu amigo divida com ele o prêmio de cinco contos. E, finalmente, deixando a brincadeira de lado, afirma:

Mas não posso deixar de observar o perigo a que a instituição do prêmio expõe as letras. Se não existem concorrentes prováveis, o fim que se teve em vista ao oferecer a dádiva foi não recompensar o mérito, o trabalho consagrado pela estima do público, mas despertar vocações, dar ensejo a experiências. E do que eu tenho medo é de que alguma comissão consagre alguma peça feita nas circunstâncias em que o meu amigo compôs a sua. Será uma boa ação em face a moral, mas um desacato às letras. $^{135}$

O crítico Fly acreditava no esforço dos nossos escritores, porque, mesmo com todas as dificuldades, continuavam a se dedicar à dramaturgia. No entanto, lamenta que, quando surgia alguma oportunidade de mostrar o resultado desse esforço, apareciam as companhias estrangeiras e arruinavam essa ocasião.

Nós, entretanto, o vemos trabalhar com uma rara heroicidade pela arte no país e, quando surge a rara possibilidade de ver coroado o seu esforço, lá vem, na sombra, esgueirando-se, humildemente, sorrateiro, um "Jean qualquer coisa", um "Bartholini" ou "Bestacroff", que sei eu! Que açambarca tudo e sorri, ao fim da empresa, da nossa estulta ingenuidade de hospitaleiros bobos. ${ }^{136}$

Em abril de 1915, O Pirralho divulgou que uma notícia abalara a imprensa carioca. A inesperada informação teria caído como uma bomba no meio teatral. Uma companhia argentina estava de viagem marcada ao Brasil, e trazia em seu repertório peças brasileiras. A novidade acalorou o debate sobre o teatro nacional. Os intelectuais, incomodados com a inércia das medidas governamentais para a valorização do teatro nacional, clamaram ao prefeito do Distrito Federal que trabalhasse nessa questão. Exigiam a adoção de medidas permanentes, como a fundação de uma Escola Dramática, e a aprovação do projeto de Alcântara

135 Idem, ibidem.

136 Revista do Brasil, número 55, julho de 1920, p. 281. 
Machado sobre autores e peças, há anos guardada na pasta de uma comissão na Câmara Municipal. Diante dessas reivindicações, o Sr. Rivadavia, prefeito do Distrito Federal, declarou que não tinha refletido sobre assunto e que ignorava a existência de artistas no Brasil. A essa declaração João Felizardo retrucou, ironicamente, aconselhando o prefeito a puxar pela memória, pois certamente encontraria, da época em que era "gabiru", a reminiscência de glórias passadas ${ }^{137}$.

Sem dúvida, a iniciativa de uma companhia estrangeira de montar originais brasileiros era uma forma de cortesia para com o país acolhedor. Contudo, era inaceitável que, enquanto nossos vizinhos optavam por montar peças brasileiras, nós as rejeitássemos.

Gomes Cardim também pretendia contribuir com a valorização do nosso teatro, pela organização de uma companhia nacional. Segundo O Echo, o anúncio desse projeto criou esperanças que não foram correspondidas desde a primeira representação da companhia. Na noite de estréia, para desgosto do crítico da revista, foi representada La Flambée, "uma das mais fortes peças do teatro francês", de acordo com suas palavras. Além disso, a formação do grupo desagradou, pois se compunha, majoritariamente, de atores portugueses, cujo sotaque diferenciava-se do nosso.

Indignado com o projeto, o crítico expressou-se de forma verborrágica:

E nós que víamos, prazeirosamente, no Sr. Cardim o Prátimas do teatro nacional!...Nós que o supúnhamos de látego em punho enxotando toda essa caterva magna de estrangeiros que, num hausto de ganância, reduziram a nossa cena a um tavolado de feira, onde exclusivamente se mira ao lucro, usando-se de todos os meios torpes, para o tornar mais grosso, como observa Coelho Neto, arrasamo-nos de lágrimas, por ver que o homem não passava de um simples empresário teatral! ${ }^{138}$

A iniciativa de Gomes Cardim também foi anunciada pelo jornal O Furão, o qual divulgou que do repertório do grupo fariam parte as peças La Flambée, Ferreira, Magda, Primeira causa, Francillon e Virgem Louca.

137 O Pirralho, número 181, 03/04/1915, ano IV.

138 O Echo, número X, abril de 1917, ano XV. 
Apesar disso, o ator e empresário ainda era considerado por muitos um defensor do Teatro Nacional. Em março de 1917, O Pirralho procurou-o com a intenção de obter informações sobre a questão do Teatro Nacional. A situação foi assim descrita:

Procuramos há dias o Sr. Gomes Cardim, para que ele nos fornecesse algumas informações sobre o teatro nacional, essa espécie de mito que a imaginação generosa de uns pregoeiros do ideal tenta soerguer, como se se tratasse de um templo desabado. ${ }^{139}$

Não o encontrando em casa, avistaram-no num café, onde, sem rodeios, indagaram-Ihe se, desta vez, o teatro nacional se levantaria. Gomes Cardim, desconfiado, sorriu e respondeu que seu único medo era de que "o teatro indígena" subisse tanto que fosse pelos ares. O diretor explicou que ouvira falar de um projeto de explodir uma bomba no Teatro Boa Vista. Diante da incredulidade dos entrevistadores, ele esclareceu que a Duse, a Réjane, o Guitry e tantos outros mantinham uma associação secreta encarregada de interromper todas as iniciativas em prol da arte dramática nacional. Isso tudo por causa da inveja que a Duse e a Réjane teriam de Lucília Peres e Itália Fausta.

Assustado com a possibilidade da bomba, Xisto Só, autor do artigo, encerra o texto aconselhando o diretor a desistir dessa empreitada, pois o seu patriotismo e seu amor à arte parariam "estatelados" diante da bomba. A entrevista é sem dúvida uma sátira à formação da Companhia organizada por Gomes Cardim.

139 O Pirralho, número 233, 27/03/1917, ano VI. 


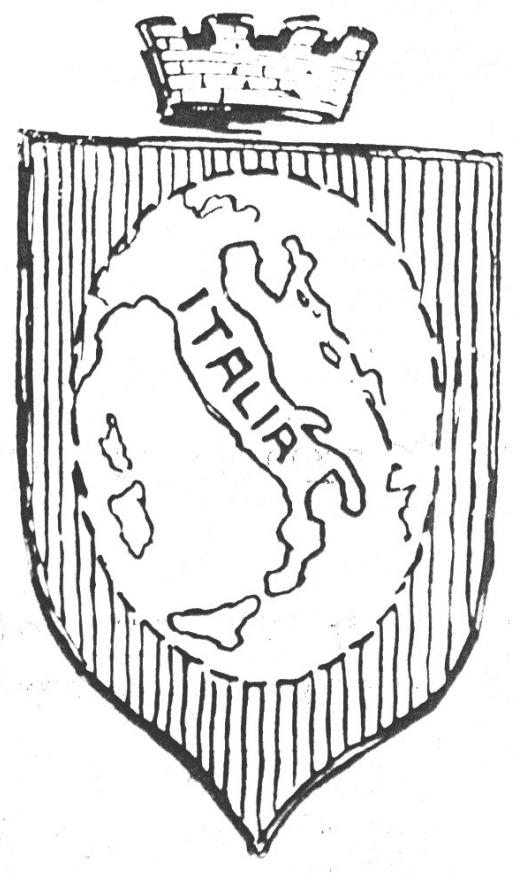

Brasão do Teatro Nacional (O Pirralho, número 233, 27/03/1917, ano VI)

Houve também outro grupo de estrangeiros muito influente em São Paulo: os italianos. Essa ação foi sentida na indústria, no comércio, na política, na vida social e, inclusive, no teatro. Organizados em associações, cujo objetivo era o da ajuda mútua em um país estrangeiro, os italianos lutaram pela preservação da sua identidade e dos seus costumes. Eram freqüentes as reuniões que contavam com a presença de um palestrante, discursando sobre política ou sobre o cenário italiano do momento, seguido de uma apresentação teatral - comumente textos pátrios - e que se encerrava com um baile.

O teatro, nestas reuniões, funcionava como uma ferramenta educativa e de perpetuação dos ideais desse povo. Desse modo surgiram os filodrammatici: teatro feito pelos italianos e para os italianos. Era comum receberem o nome de acordo com a sua filiação ideológica ou em homenagem a algum italiano famoso: Eleonora Duse, Paolo Ferrari, Gremio Drammatico Garibaldi etc. Nomes importantes do teatro brasileiro, como o de Nino Nello e de Itália Fausta, surgiram desse meio.

Os filodrammatici tiveram um papel decisivo no teatro brasileiro. Porém, como faziam um teatro afastado das grandes salas de espetáculo e, 
principalmente, do ideal burguês, não tiveram o destaque merecido. Não foram encontrados anúncios sobre o trabalho realizado por esses atores nas revistas pesquisadas. Segundo Magaldi e Vargas, esses grupos foram desaparecendo, à medida que os imigrantes integraram-se ao novo meio ou que a censura tornou-se mais violenta, no caso dos grupos de ideais anarquistas ${ }^{140}$.

Passadas as incertezas dos primeiros anos da República, o início do século seguinte presenciou uma fase de estabilidade e indícios de um futuro promissor, mas instalou no país uma cultura de valorização do elemento estrangeiro, com o intuito de sedimentar de vez o passado colonial e abrir caminho para um país moderno, em busca do progresso. A fim de romper definitivamente com uma imagem arcaica e escravista, o país entregou-se a uma busca pelos modelos europeus de civilidade e modernização. Vivíamos nesse momento, de acordo com Antonio Candido, um "desejo de ser estrangeiros"141.

Dessa situação surgiu um embate entre dois grupos: uma elite ansiosa por se encaixar nos padrões europeus, sobretudo franceses, e um grupo de intelectuais bradando pela valorização dos elementos nacionais. O que nos revela o caráter ambíguo deste momento: uma sociedade ainda presa às suas tradições e ao mesmo tempo ansiosa por renovações. O confronto cosmopolitismo versus nacionalismo, dominante na época, extravasou para o campo das artes, disseminando a tese de morte ou de "decadência" do teatro nacional. Prestigiar companhias estrangeiras de teatro era uma maneira de se enquadrar nesse novo paradigma de civilização e exibir uma mentalidade cosmopolita.

É fato que as companhias estrangeiras, preferidas por empresários teatrais, desfavoreceram as companhias nacionais, mas o que realmente representou um entrave para o crescimento do teatro nacional foi o "desejo de ser estrangeiros"142.

140 MAGALDI \& VARGAS. Op. cit. p. 32.

141 CANDIDO, Antonio. "Literatura e subdesenvolvimento" . pp. 140-162. In: A Educação pela Noite e Outros Ensaios. São Paulo: Ática, 2000. 142 Idem, ibidem. 


\subsection{A prosódia lusitana}

Um dos motivos que têm contribuído para entravar o desenvolvimento do teatro nacional é a prosódia usada em nossos palcos, na maioria dominados por artistas estrangeiros, sobretudo portugueses. ${ }^{143}$

O destaque dado ao teatro estrangeiro, como visto, não favoreceu o desenvolvimento de um teatro nacional. Apontada como uma das causas da "decadência" do teatro brasileiro, a primazia do teatro europeu sobre o brasileiro trazia consigo um outro fator que, segundo a opinião vigente, colaborava com esse processo: a prosódia lusitana usada em nossos palcos.

Júlio Nogueira, do Jornal do Comércio, chamara a atenção para o fato de que nós, brasileiros, representávamos, geograficamente, a maioria dos falantes da Língua Portuguesa e era, portanto, incompreensível que nos colocássemos em posição de submissão à prosódia lusitana. Não que uma fosse superior à outra; no entanto, a prosódia deveria ser considerada como marca da diferença entre os povos $^{144}$.

Como herdeiros da colonização portuguesa, é natural que nos fosse transmitido o linguajar típico do português, mas é uma distorção querer perpetuá-lo mecanicamente, sem levar em conta as transformações lingüísticas. Tal situação encontrava-se no teatro, cujos representantes, atores e dramaturgos, empenhavam-se em falar e escrever à maneira lusitana.

No entanto, a sede de nacionalismo, marca do período pós Proclamação da República, revelou um dado a ser modificado. Se o teatro deveria ser o reflexo de uma sociedade, da cultura e dos costumes de um povo, então havia algo de errado na maneira de falar daquele protótipo de brasileiro.

Antes, pode ser que não houvesse motivos para questionar tal hegemonia lingüística, todavia as mudanças no cenário político e econômico do país trouxeram

143 Revista do Brasil, número 38, ano IV, Volume X, fevereiro de 1919, pp. 237-238. Artigo publicado originalmente no Jornal do Comércio e reproduzido na Revista do Brasil.

144 Idem, ibidem. 
inquietações a esse respeito, pois, lembremo-nos, agora se necessitava da afirmação da identidade nacional.

Cláudio de Souza, quando questionado, em inquérito promovido pelo Correio Musical Brasileiro, se achava inconveniente que artistas nascidos em outros países participassem de uma companhia nacional, respondeu que não haveria inconveniente nenhum, desde que esses artistas adotassem nossa prosódia $^{145}$.

Além de se preocupar com a prosódia no teatro, o dramaturgo, no artigo "Os estrangeirismos em nosso teatro", critica a incorporação de palavras estrangeiras, principalmente do inglês e do francês, ao nosso vocabulário ${ }^{146}$. Cláudio de Souza também não admitia a postura de alguns escritores, como Monteiro Lobato, por exemplo, de defesa de um dialeto brasileiro. O autor de Urupês defendia a tese de que algumas expressões estrangeiras seriam necessárias ao idioma, uma vez que não havia palavras que pudessem ser utilizadas no lugar daquelas. Além disso, levava em consideração a contribuição do negro, do índio, do imigrante italiano e do alemão na formação do português falado no Brasil.

Cláudio de Souza protestava que esse argumento contribuía para com o caos lingüístico, a anarquia, e, se permanecêssemos nesse caminho, ninguém mais se entenderia, como ocorrera em Babel. A propagação da idéia de adoção do dialeto brasileiro como nossa língua era para ele inadmissível. A citação de Rui Barbosa utilizada pelo dramaturgo elucida sua posição:

Depois que se inventou o "dialeto brasileiro" todas as mazelas e corruptelas do idioma que nossos pais nos herdaram cabem na indulgência plenária dessa forma de relaxação e de desprezo da gramática e do gosto, e do abandono dos bons modelos da linguagem, cuja história, cujos monumentos e cujos destinos se entrelaçam com os da nossa raça, e os da nossa nacionalidade. ${ }^{147}$

145 Correio Musical Brasileiro, número 2, 15-31 de maio de 1921, ano I.

146 SOUZA, Cláudio de. “Os estrangeirismos em nosso teatro». In: Revista da Língua Portuguesa, ano I, número 5, maio de 1920, pp. 115120.

147 Idem, ibidem 
O dramaturgo era, portanto, defensor da prosódia brasileira nos palcos, mas contrário à criação de um dialeto brasileiro. Falar à brasileira, para ele, não significava reproduzir expressões populares e restringia-se à pronuncia, ou seja, à parte fonética da língua.

Deturpar, porém, a linguagem, trazer para a cena, de preferência, todas as aberrações e vícios populares, é prestar mau serviço às letras e ao público, e concorrer, poderosamente, com a força viva dos exemplos animados, para o desbaratamento do melhor, do mais querido, do mais sagrado de todos os patrimônios nacionais... ${ }^{148}$

A reprodução da linguagem popular, conforme acreditava, desmerecia a língua nacional.

-Tu me qué mêmo, minha nega?

-Entonce não te havéra de querê?

- Não fala, não! Tu é o suco! (E atirando-se ao pescoço da mulher, a beijá-la): Ai, que cangote cheiroso...Deixa teu batuta te beijá!...

-Oxente!....Não me estraga! Sai, azá! ${ }^{149}$

Os criadores de diálogos como o anterior, a seu ver, enxergavam o teatro como comércio, e não como escola de bons costumes.

Quanto à incorporação de estrangeirismos em nossa língua, sugeriu que cada um em seu ramo de atividade cuidasse da retirada dos vocábulos não pertencentes a ela. Como seu ramo era o teatro, Cláudio de Souza listou quarenta e uma palavras estrangeiras utilizadas no meio e propôs outras em português. Em lugar de matinée propôs vesperal; estréia seria mais apropriado que debute; em vez de reprise podíamos usar repetição, e para divette admitir-se-ia o diminutivo divinha ou diveta, por exemplo.

148 SOUZA, Cláudio de. “Clássicos no teatro». In: Revista da Língua Portuguesa, ano IV, número 19, setembro de 1922, pp. $275-292$. 
Em nota final do texto, acrescenta que a empresa do teatro Trianon, de São Paulo, resolvera adotar a expressão vesperal, em substituição a matinée, assim como excluir qualquer estrangeirismo de seu programa. Outros teatros da capital fizeram o mesmo, informou, e o jornal $O$ Estado de $S$. Paulo também adotou a sugestão.

A publicação desse texto data de 1920, período em que Oduvaldo Vianna está envolvido na luta pela nacionalização do teatro brasileiro. A sua peça Terra Natal, escrita em 1920, por exemplo, tinha o intuito de defender os valores nacionais em oposição aos estrangeiros. O texto privilegiava uma linguagem nacional, servindo-se de regionalismos e variantes do falar brasileiro.

O enredo nos conta sobre o personagem Oscar, que volta ao Brasil, sua terra natal, após um período de vivência no exterior. Semelhante ao personagem Henrique, de Flores de Sombra, Oscar retorna encantado com a cultura estrangeira, menosprezando os costumes de seu país. No entanto, ao enfrentar dificuldades financeiras receberá ajuda do filho de um roceiro, que the salva a fazenda da ruína. A partir daí, sentirá um grande apreço por sua terra natal.

A dicotomia entre o elemento nacional e o estrangeiro mais uma vez é discutida em cena:

Oscar- (...) Se em algum lugar eu tivesse um datilógrafo americano, alemão, inglês, de outra nacionalidade, enfim, que não fosse a brasileira, o serviço andaria perfeitamente em ordem.

(...)

Nhozinho- Oscar, essa tua ojeriza a tudo quanto é nacional está se tornado perigosa. ${ }^{150}$

A valorização do estrangeiro reaparece em outros diálogos:

Maria- Meu filho, você vem de São Paulo, mas vem brasileiro, não vem?

laiá- O Oscar é um ianque perfeito. Perdeu a noção de nacionalidade.

150 MADEIRA, Wagner Martins. Formas do teatro de comédia: A obra de Oduvaldo Vianna. Tese de Doutorado. Letras, FFLCH/USP. São Paulo, 2003. 
Oscar, em outro momento, associa a idéia de nacional à de atraso:

Oscar- O carro de boi é muito nacional. O carro de boi é um atraso. ${ }^{151}$

Um ano após escrever Terra Natal, Oduvaldo Vianna, agora junto de Viriato Corrêa e Nicolino Viggiani, envolve-se em um projeto que tinha por objetivo montar uma companhia nacional, tanto na formação do elenco quanto no repertório a ser encenado. Por terem trabalhado no teatro Trianon, essa iniciativa ficou conhecida como "Geração Trianon".

Após desentendimentos com Viriato Corrêa, Oduvaldo Vianna funda a Companhia Brasileira de Comédias, ainda comprometido com a difusão do linguajar brasileiro.

Registra-se que a incorporação da prosódia brasileira, com gírias e expressões típicas do falar carioca, ocorrera com a representação da burleta Forrobodó, de Luís Peixoto e Carlos Bettencourt, em 1912 152 . Até então mesmo o gênero revista, caracterizado como teatro popular, utilizava-se da prosódia lusitana. Essa foi sendo substituída pela prosódia brasileira por meio, principalmente, do teatro popular: comédia de costumes, burletas e revistas. Com o intuito de aproximar do público os personagens apresentados, os autores colocavam em cena o malandro carioca com seu linguajar típico, o imigrante italiano e, com o surto regionalista, o caipira, reproduzindo o falar "caipirês".

Vale ressaltar que em São Paulo, devido à imigração italiana, alguns autores incorporaram o "italianês" em suas peças, com o intuito de tipificar o imigrante.

Comentando a primeira revista paulista encenada, O Boato, em 12/05/1899, Neyde Veneziano declarou que a mistura de sotaques, presente na peça, servia como recurso cômico e era um retrato da cidade revistada ${ }^{153}$.

Na coluna "Teatros" do periódico O Queixoso, o colunista, sob o pseudônimo de W. Kiritiko, assume uma postura desfavorável à ocupação estrangeira, quanto à linguagem utilizada nos espetáculos:

151 Idem, ibidem.

152 VENEZIANO, Neyde. Op. cit. p. 170-171.

153 VENEZIANO, Neyde, Op. cit. p. 80. 
O [teatro] Apolo também trabalha. É ainda outra a língua...Positivamente isto vai ficando uma Babel de teatro. Só não há aqui um teatro em...português de brasileiro. É a única língua que falta. ${ }^{154}$

Um dos críticos de $O$ Echo assegurava que para a regeneração do teatro nacional ou a sua criação era fundamental fazer como outros países: trabalhar nos conservatórios com um grupo de artistas nacionais, com o intuito de falar à moda de seu país e pensar como os seus concidadãos ${ }^{155}$.

Júlio Nogueira, no artigo "A prosódia brasileira no teatro", afirmou que a prosódia usada em nossos palcos, influenciada por artistas estrangeiros, principalmente portugueses, representava um entrave para o desenvolvimento do nosso teatro. Para que escutássemos um linguajar diferente do de Portugal era necessário ir a uma das casas de teatro do Rocio, onde se exibiam peças genuinamente populares ${ }^{156}$.Os diretores de cena estariam entre os responsáveis por essa situação, pois, além de não cuidarem da nossa prosódia, ainda exigiam que os atores falassem à maneira lusitana:

Parece aos nossos diretores de teatro que não pode haver cenas de efeito sem o apertado ritmo lusitano a que nossos jovens artistas se têm de ajeitar... ${ }^{157}$

Indignado com esse quadro, lastimou que o nosso país que tanto contribuiu com a língua portuguesa, e que, de acordo com suas palavras, tanto a enriqueceu, cobriu-a de novas galas, rejuvenesceu-a e lhe deu frescura e suavidade seja preterida em favor da prosódia lusitana no nosso teatro. Ainda mais quando essa arte é caracterizada como a reprodução do meio social nos seus vários aspectos.

Para melhor perceber a indignação do crítico diante dessa situação, reproduzimos o seguinte trecho:

154 O Queixoso, número 1, 09/12/1905, ano I, p 13.

155 O Echo, número X, abril de 1917, ano XV.

156 Revista do Brasil, número 38, fevereiro de 1919, ano IV, Volume X, pp. 237-238. Artigo publicado originalmente no Jornal do Comércio e reproduzido na Revista do Brasil.

157 Idem, ibidem. 
Entre o acento lusitano e a gíria dos nossos morros e bairros, povoados de capadócios, está a linguagem da sociedade brasileira, a linguagem do nosso meio culto, dos nossos homens de letras, dos nossos oradores, dos nossos salões. Que falem à maneira lusitana personagens portugueses, em cenas portuguesas, está muito bem, como bem está que o arruaceiro da saúde ou favela fale o seu calão. Exigir, porém, que intérpretes nacionais estropiem a prosódia portuguesa, que, digase de passagem, não sabem reproduzir convenientemente, é ter em muita pouca estima a língua que aqui se fala e procurar submeter uma sociedade inteira a uma vassalagem que já desapareceu, para todos os efeitos, desde $1822 .{ }^{158}$

Júlio Nogueira declarou ainda que os autores, os quais trouxeram para a cena fatos das nossas capitais e dos sertões, marcaram um novo período do teatro brasileiro. E para que as cenas de nossa vida pudessem ser reproduzidas de maneira aceitável, ninguém mais, senão um artista brasileiro, seria capaz de interpretá-las.

O caminho para o ressurgimento do teatro nacional, portanto, apontava para o banimento definitivo da prosódia lusitana dos palcos, e para a implantação da brasileira. Segundo o colunista, a sua impressão das peças encenadas no momento em questão era diminuída em virtude desse "velho erro", essencial de ser corrigido.

O jornalista concluiu que esse debate merecia as atenções dos nossos comediógrafos, críticos e diretores de teatro, para que numa ação conjunta aconselhassem ou permitissem que se falasse em cena somente o português do Brasil, o qual nada tinha a dever ao português de além-mar.

158 Ibidem. 


\section{$1.6 \mathrm{O}$ cinematógrafo}

Dizem que a decadência do teatro em nossa terra provém diretamente do desenvolvimento grandioso que o cinematógrafo tomou. ${ }^{159}$

A popularidade alcançada pelo cinematógrafo no início do século $X X$ preocupou os artistas de teatro. A sua difusão como espetáculo de diversão e entretenimento indicava, para críticos e intelectuais, mais um fator de contribuição para a "decadência do teatro brasileiro".

A princípio, pequenas notas nas seções destinadas ao teatro anunciavam a estréia de um cinematógrafo; aos poucos, ganharam relevo nas páginas dos periódicos. Por fim, chegaram, em alguns casos, a monopolizar as seções.

Em 1908, a revista Vida Paulista profetizava que o cinematógrafo acabaria por suplantar de vez as companhias teatrais. Por essa razão, protestavam os empresários teatrais, que viam o público "debandar em massa" para o Bijou Theatre, e deixarem as salas de teatro "às moscas". Nesse ano, o Bijou Theatre, o Colombo, Salão dos Atos do Lyceu e, inclusive, o Salão da Rotisserie Sportsman reservaram espaços às projeções. Os espetáculos da casa Pathé Frères, de Paris, ou da empresa Serrador, que trabalhava no Bijou, garantiam enorme público, prejudicando o teatro, independente do gênero exibido:

O cinematógrafo, hoje em dia, oferece ao público diversão variada, havendo quem diga - com razão - que mais vale uma função cinematográfica do que certas representações de operetas com cantores afônicos, que não correspondem aos preconícios de que vêm precedidos. ${ }^{160}$

Em agosto de 1908, a Vida Paulista volta a ratificar o sucesso do cinematógrafo junto ao público:

159 A Cigarra, número 95, 12/07/1918, ano V.

160 Vida Paulista, número 125, 28 e 29/06/1908, ano III. 
O Bijou Theatre navega também em maré de sucesso. A concorrência a esse elegante centro de diversão aumenta, cresce, avulta de noite para noite, provando assim a predileção do público pela cinematografia. E como não ser assim?

O cinematógrafo está em moda, e não há quem possa furtar-se aos caprichos dessa soberana governante das multidões civilizadas. ${ }^{161}$

Aliada ao cinematógrafo, a crítica designa de civilizadas as "multidões" apreciadoras dessa arte.

Em 1911, a Ilustração Paulista traz o artigo "Os progressos de São Paulo. O cinema Íris-Theatre"162. O assunto discutido é, certamente, o domínio do cinematógrafo. Segundo consta, há tempos um conhecido escritor afirmara que o teatro cederia, forçosamente, terreno à cinematografia, uma vez que esta arte não enfrentava obstáculos ao seu desenvolvimento, sempre apresentando obras de rara perfeição.

Em São Paulo Futuro há uma menção à boa receptividade do cinematógrafo:

Barriga Verde - Ah! Meu amigo isto até parece fita de cinematógrafo. Oh! O cinematógrafo.

Gaudêncio - Que coisa é essa de em cima da sogra?

B. Verde - O cinematógrafo, meu amigo, é um sujeitinho para quem não há crise de espécie alguma.

O Pirralho vislumbrou uma guinada na maré de sorte cinematográfica no período da Guerra de $1914^{163}$. Acreditou, por um instante, que a guerra trouxeranos um benefício ao dificultar a vinda de novidades em filmes. Chegou até a falar em "decadência do cinematógrafo". João Felizardo, ao expressar essa opinião, relatou que há muito havia notado, "com íntima satisfação", o crescente desinteresse das pessoas pelo cinematógrafo. Entretenimento cujos efeitos ele considerou tão nocivos quanto os do jogo do bicho.

161 Vida Paulista, número 133, 23 e 24/08/1908, ano III.

162 llustração Paulista, número 15, 15/04/1911, ano I.

163 O Pirralho, número 192,19/06/1915, ano IV. 
Após a conflagração mundial, a situação do cinematógrafo só piorou. Para driblar essa crise, os empresários viam-se obrigados a investir nos "réclames", a fim de manter a casa cheia. Entretanto, como esses esforços não trouxeram resultados positivos, João Felizardo afirmou que o cinema, "agonizante", teve que estender a mão ao teatro e pedir-lhe o socorro dos números de variedades. Eis quando aparecem os números mistos de palco e tela. Todavia, o escritor acreditava que não tardaria o dia em que o cinematógrafo seria "obrigado a ceder completamente ao teatro o lugar usurpado".

A Cigarra não via justificativas para que o público preferisse o cinema ao teatro. Este poderia conviver em harmonia com aquele, sem prejudicarem um ao outro. Ambos, do ponto de vista artístico, apresentariam grandes diferenças, segundo o periódico. Os artistas mímicos, por exemplo, como Capozzi, seriam péssimos na comédia ou no drama de palco. Assim sendo, não era possível entender o motivo dessa predileção. Entretanto, $A$ Cigarra mesmo esclarece tal dúvida. De acordo com sua explicação as pessoas preferiam o cinema porque os empresários das casas produtoras de filmes mostravam um cuidado que não se encontrava nas casas teatrais. Esse cuidado se traduzia na preocupação de aliar à criação fatos da vida real, ou da fantasia, "temperados sempre, como queria Eça, com uma moralidade discreta". O segredo do sucesso estaria nessa receita.

$\mathrm{O}$ articulista conclui afirmando que o Teatro Nacional poderia equiparar-se ao cinema em sua prosperidade, desde que os nossos escritores teatrais compreendessem que nenhuma criação é capaz de agradar, ou de durar se não for aliada da "Arte e da Moral". De acordo com ele, o exemplo parecia estar vindo do Rio de Janeiro, onde já havia "comédia limpa, de caracteres, que é estudo e é escola, que diverte e ensina, que agrada sem dar travor ao paladar". Supomos que se trate da Companhia de Leopoldo Fróes, que nesse momento já era bastante reconhecida.

A indústria do cinema surgiu com força no início do século $X X$, e passou a concorrer com o teatro. Paulatinamente, sobrepôs-se a este nas páginas periódicas e como um negócio mais lucrativo para os empresários. Com o nascimento de Hollywood, em 1915, o cinema popularizou-se mais ainda, tendo o Brasil como um 
dos seus mercadores consumidores. Entre a tela e o palco, sobressaiu-se a primeira, por apresentar-se como meio de divulgação mais eficiente e como um negócio mais rentável ${ }^{164}$.

Entretanto, é preciso esclarecer que o êxito do cinema não significou a "decadência do teatro brasileiro" para o nosso estudo, uma vez que consideramos o desenvolvimento cinematográfico um processo paralelo ao desenvolvimento do teatro. Em uma sociedade em formação, é natural que surjam outras formas de entretenimento capazes de atrair numeroso público. O interesse do público pelo cinema não indica a rejeição pelo teatro, ou seu abandono definitivo, pois, como já afirmara o crítico de $A$ Cigarra, há diferenças entre essas duas artes, mas também há muitas semelhanças.

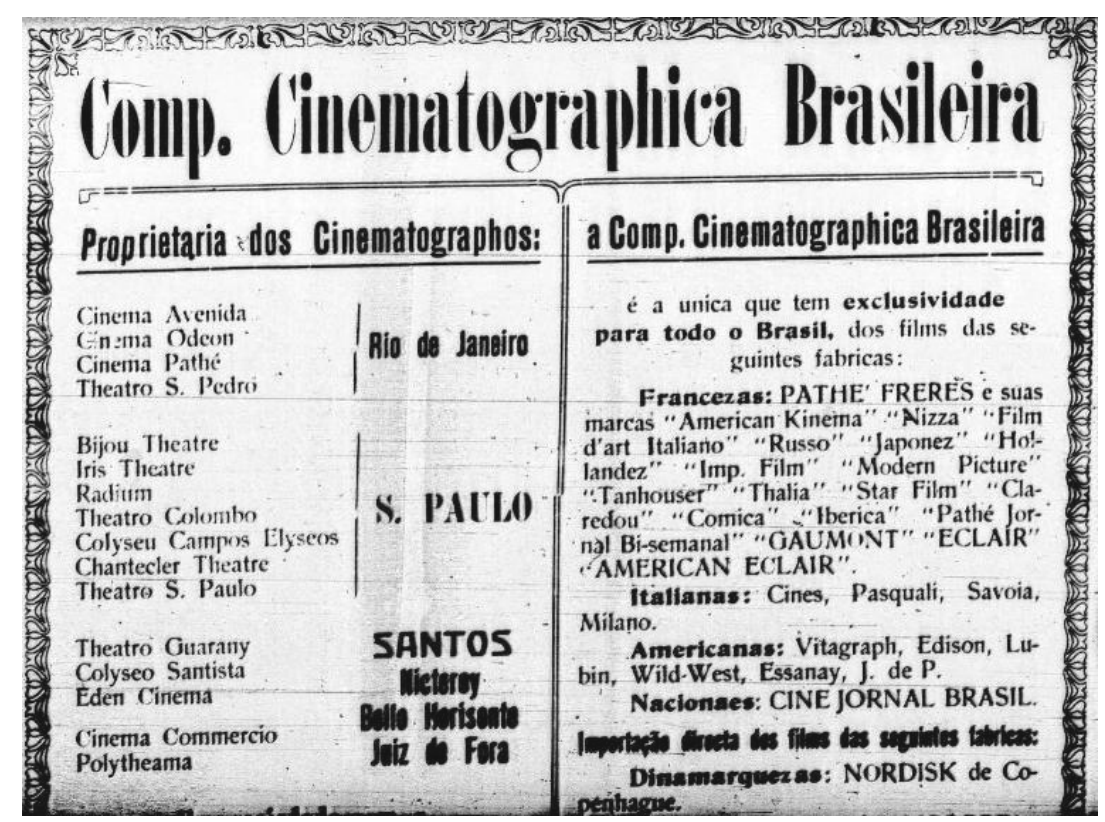

(O Pirralho, número 51, 27/07/1912, ano II)

164 MARTINS, Ana Luiza. Revistas em Revista: Imprensa e Práticas Culturais em Tempos de República, São Paulo (1890-1922). São Paulo: Editora da Universidade de São Paulo: Fapesp: Imprensa Oficial do Estado, 2001, p. 403. 


\section{Capítulo II}

\section{A valorização do teatro nacional}

Paulatinamente, o teatro nacional voltou a despontar em meio ao cenário dominado por companhias estrangeiras. Mesmo desconsideradas pelos críticos, as revistas de ano e as operetas tiveram um público cativo, o que lhes garantiu significativo espaço quando o assunto é teatro nacional.

Após a encenação da revista de Arlindo Leal, O Boato, em 1899, alguns anos se passaram para que o teatro nacional voltasse revigorado. Em março de 1909, por exemplo, a vinda a São Paulo da Companhia dramática do Teatro da Exposição representou um grande acontecimento por apresentar um repertório essencialmente brasileiro: Quebranto e $A$ Nuvem de Coelho Neto; $O$ dote e $O$ genro de muitas sogras, de Artur Azevedo; As doutoras, de França Júnior; $O$ noviço e Os irmãos das almas, de Martins Pena, entre outras ${ }^{165}$.

As revistas começaram a ganhar mais destaque a partir de 1911. Como apontamos no capítulo I, algumas, segundo o jargão da imprensa, obtinham "numerosas enchentes".

Entre os anos de 1910 e 1914, surgiu a manifestação nacional-regionalista. Esse movimento tinha o intuito de resgatar as raízes brasileiras, a fim de afirmar a identidade do país como nação independente, e combater a europeização. O teatro paulista deu início à reação regionalista, com peças como Flores de Sombra, Onde canta o sabiá, Nossa terra, A Juriti e O Contratador de Diamantes. Ao lado dos dramaturgos paulistas, o ator Sebastião Arruda representou esse movimento.

À parte o movimento regionalista, destaca-se a empreitada de Gomes Cardim e a Companhia Dramática Nacional, tendo à frente a atriz Itália Fausta; Leopoldo Fróes; e os dramaturgos Oswald de Andrade, Guilherme de Almeida e João do Rio.

165 MAGALDI, Sábato \& VARGAS, Maria Thereza. Op. cit. p.48. 


\subsection{A cidade de São Paulo como cidade das artes e do teatro}

São Paulo já é alguma coisa, e vale a pena entrar no palco por essa porta. ${ }^{166}$

A citação da frase de Monteiro Lobato expressa a crescente importância da cidade de São Paulo no panorama do país no início do século XX. A cidade crescia não só do ponto de vista financeiro, mas também do ponto de vista cultural e artístico.

Para gáudio da população paulista, quando da visita da grande atriz Sara Bernhardt, ela se referiu à cidade como a "capital artística do país". Certamente, querendo mostrar-se agradável. No entanto, os intelectuais paulistas aproveitaramse dessa "deixa" para a confirmação do status que pretendiam impingir a São Paulo.

Conforme Paulo Prado ${ }^{167}$ :

Foi a sua imaginação complicada de mulher, de cômica e de judia, que inventou e nos ofereceu em adulação interesseira esse qualificativo, aceito com entusiasmo, de capital artística do Brasil. Nele vinha envolto na lisonja o veneno delicioso-criador de sonhos e ilusões - a que um escritor francês, inventor do termo, chamou bovarismo.

Ainda segundo o escritor, "bovarismo é o dom que possui o homem de se imaginar diferente do que é". Esse sentimento, a seu ver, associava-se perfeitamente à cidade de São Paulo, a qual se encontrava em transformação, e, portanto, precisava criar uma imagem. Do bovarismo advinha um excesso de orgulho e vaidade e, a partir dessa ilusão, criou-se a idéia presunçosa de São Paulo-nação. Entretanto, de todas as pretensões "megalomaníacas" dos paulistas, nenhuma excedia a certeza de que éramos a "capital artística do país"168.

166 LOBATO, Monteiro. A Barca de Gleire: Quarenta Anos de Correspondência Literária entre Monteiro Lobato e Godofredo Rangel. São Paulo, Brasiliense, 1948, p. 11

167 PRADO, Paulo. Paulística etc. São Paulo: Companhia das Letras, 2004, p. 297.

168 PRADO, Paulo. Op. cit., pp. 297-298. 
Conforme Décio de Almeida Prado ${ }^{169}$, o enriquecimento da cidade a fazia figurar como o segundo centro teatral do país, logo após o Rio de Janeiro. Porém, estar nessa posição já não era suficiente, era preciso ser o primeiro. Ademais, tornara-se imprescindível conferir-lhe o status de centro intelectual, de onde saíam os principais pensadores do país.

Tânia de Luca, em estudo sobre a Revista do Brasil, afirma que a revista, "que se intitulava do Brasil mas sempre foi um empreendimento paulista", desempenhou importante papel nessa missão ${ }^{170}$. Os intelectuais paulistas reivindicavam para si a supremacia literária porque julgavam ter respostas para o grande problema da produção brasileira: o de ser subserviente a tudo quanto fosse estrangeiro. A valorização do regional seria a solução para esta questão, pois seriam criados nossos próprios métodos, sem uma influência estrangeira. São Paulo, que já fornecia os elementos para o enriquecimento da nação, agora revelaria ao país como fazer sua própria arte.

À imagem de São Paulo como a locomotiva, o carro-chefe da nação, procurava-se incorporar a imagem de pólo cultural do país, centro de onde irradiaria um projeto nacionalizador ${ }^{171}$.

O periódico O Queixoso, de janeiro de 1916, traz uma seção intitulada "Capital Artística", como uma referência à cidade. Na coluna Teatros, novamente encontramos o epíteto, apesar de, neste caso, vir seguido de uma crítica sobre as temporadas nos teatros:

Em S. Paulo, na celebérrima "Capital Artística" não se pode manter uma seção quinzenal sobre teatros. $-E$ a verdade nua e crua. ${ }^{172}$

Conhecendo, porém, a linha satírica adotada pela revista, podemos desconfiar da intenção dos colunistas ao se referirem dessa forma à cidade.

O Pirralho também confere sua dose de ironia:

\footnotetext{
169 PRADO, Décio de Almeida. “O teatro em São Paulo». In: Marcondes, J.V.F. \& Pimentel, O. São Paulo. Espírito. Povo. Instituições. São Paulo: Livraria Pioneira Editora, 1968.

170 LUCA, Tânia Regina de. A Revista do Brasil - Um Diagnóstico para a (N)ação. São Paulo: UNESP, 1999, p. 300.

171 Idem, ibidem, p. 283.

172 O Queixoso, número 4, 29/01/1916, ano I.
} 
Sarah Bernhardt disse, com muita razão, que São Paulo é a capital artística do Brasil. E como o nosso orgulho vibrou diante de tais palavras!

Provas não faltam do nosso gosto artístico. Os cinemas vivem cheios. É uma arte como outra qualquer. Os teatros não apanham enchentes mas a arte anda tão abastardada, nesses lugares...

Imaginem se a Sarah volta a São Paulo! Então, sim, ela verá que ainda disse muito pouco. $^{173}$

A Vida Moderna, ao comemorar o aniversário da Companhia Arruda, situa São Paulo entre os obstáculos enfrentados pelo grupo em sua trajetória, uma vez que não propiciava um meio receptivo à arte teatral ${ }^{174}$. Não obstante alguns comentários dessa natureza, os colunistas não perdem a oportunidade de glorificar a cidade:

De S. Paulo têm partido todas as grandes iniciativas, e quando elas partem daqui, é certo o seu êxito. ${ }^{175}$

A citação acima se encontra em um artigo sobre a Companhia Dramática Paulista, dirigida por Gomes Cardim, a qual passará a ser chamada de Companhia Nacional. O texto realça a importância de Itália Fausta e Lucília Perez, "as duas grandes artistas paulistas", cujos nomes eram celebrados no teatro contemporâneo brasileiro e português ${ }^{176}$.

Carneiro Leão, colunista d'A Cigarra, enfatiza que a criação do Teatro Nacional fora uma iniciativa tomada por São Paulo:

Bela iniciativa tomada por S. Paulo, criando o Teatro Nacional, é de um alcance extraordinário.

$(\ldots)$

173 O Pirralho, número 238, 20/05/1917, ano VI.

174 A Vida Moderna, número 340, 25/07/1918, ano XIV.

175 A Vida Moderna, número 309, 12/04/1917, ano XIII.

176 Idem, ibidem. 
S. Paulo está pondo eloqüentemente à prova que podemos possuir um teatro nacional, onde haja dignidade e decoro artístico... ${ }^{177}$

Em 31/05/1917, esse mesmo periódico publica um artigo elogiando a atriz Itália Fausta, e não perde a oportunidade de expressar-se favoravelmente acerca do público paulista:

Felizmente o público de S. Paulo, que sabe compreender e apreciar os grandes artistas, demonstrou também que era capaz de compreender a sua grande alma, o seu belo talento e deu-lhe provas de inequívoca admiração, aclamando-a com delírio. ${ }^{178}$

No período delimitado neste estudo, encontram-se nas revistas pesquisadas importantes eventos teatrais, tais como a iniciativa de Gomes Cardim e a Companhia Dramática Paulista; o trabalho de Arruda e sua Companhia; as peças escritas em francês - de Oswald de Andrade e Guilherme de Almeida; escritores como Danton Vampré, Arlindo Leal e Cláudio de Souza, que se não figuram entre grandes nomes de nossa dramaturgia, ao menos deram continuidade ao teatro brasileiro; grandes artistas, como Itália Fausta, Nino Nello, Sebastião Arruda; e os esquetes de Mário de Andrade, que mesmo sem serem encenados, constituem textos importantes para a literatura dramática brasileira.

É de se notar, portanto, que a desvalorização do teatro feito em São Paulo no início do século XX, considerando o panorama teatral brasileiro como um todo, foi um tanto quanto injusta.

177 A Cigarra, número 64, 18/04/1917, ano IV. 178 A Cigarra, número 67, 31/05/1917, ano IV. 


\subsection{As companhias nacionais e paulistas}

Decorridos vinte anos do início do século $\mathrm{XX}$, o teatro brasileiro ainda era depreciado pelos intelectuais. Otávio Quintiliano, em outubro de 1922, afirmou:

O teatro no Brasil, após quase um século de vida, reduz-se assim, hoje, ao teatro de importação, explorado pelas companhias que nos visitam anualmente. Teatro Nacional, o que em rigor se chama teatro, nós não o possuímos, atualmente, por falta de empresas que a ele se dediquem, ou do amparo constante e proveitoso do governo. ${ }^{179}$

O amparo governamental era algo desejado há muito tempo. Os críticos consideravam-no de extrema importância para o reconhecimento do teatro como atividade profissional. Cláudio de Souza, por exemplo, via nessa iniciativa um passo para a formação de um teatro sério, em que o interesse pela arte superasse a especulação comercial ${ }^{180}$. Abadie Faria Rosa, no entanto, nem acreditava na existência do teatro nacional:

Para mim é um grande erro dizer que o teatro no Brasil está decadente, para mim ele nunca existiu. ${ }^{181}$

Próximo à data de comemoração do Centenário da Independência, Coelho Neto declarou que se houvesse um esforço para reunir alguns bons atores - só brasileiros - a fim de formar uma companhia nacional, teríamos uma companhia para representar o teatro, a contento, nas festas do Centenário. Com essa declaração, nota-se a desconsideração do dramaturgo pelo trabalho realizado por algumas Companhias, entre elas a Companhia Arruda, que desde 1916, obtinha uma grande aceitação entre o público.

179 Revista do Brasil, número 82, outubro de 1922, ano VII, Volume XXI, pp.181-186. 180 Correio Musical Brasileiro, número 1, 1-15 de maio de 1921, pp.13-15. 


\subsubsection{A Companhia Arruda}

A 25 de julho de 1918, o periódico A Vida Moderna publicou um artigo em comemoração ao aniversário de instalação da Companhia Arruda no teatro Boa Vista. O que se afirmava, segundo $O$ texto, era que todas as companhias organizadas em São Paulo estavam fadadas ao insucesso. A Companhia Arruda, porém, contrariara esse padrão.

Sebastião Arruda, paulista de Louveira, ingressou no teatro ainda criança, aos 10 anos de idade e, com o tempo, passou a ser um dos atores mais populares da cidade de São Paulo. Em 24/04/1915, O Pirralho comentou o sucesso da peça O caça-dotes, de Fábio Barboza Lima, pela Companhia Nacional Arruda Rocha ${ }^{182}$. O Monóculo, de 12/06/1915, chama a atenção para o "franco sucesso" da trupe Arruda no teatro Rink ${ }^{183}$. Em maio desse mesmo ano, Arruda recebe elogios de $O$ Pirralho. J. Felizardo, aprovando o gosto do público paulistano, observa que conhecia bem o público dessa cidade desde 1912, quando ele "acorria ao Santana para ver o Arruda, o Taveira, o Edmundo Silva". Em todas essas anotações não aparece o nome Sebastião Arruda, mas é quase certo que se referem a ele mesmo, já que o outro Arruda famoso, Genésio, só virou ator anos mais tarde, quando o primeiro já estava estabelecido no meio.

A fundação da Companhia Arruda surgiu da iniciativa de Arruda e de Abílio de Menezes, os quais, em 29 de agosto de 1916, na cidade de Mococa, organizaram uma associação, cujo sucesso seria verificado rapidamente. $O$ elenco, encabeçado por Sebastião Arruda, contava com Abílio de Menezes, José Ribeiro, J. Teixeira, Vicente Felício, Antonio Soares, Agostinho Tavares, Moreno Soares, Celestino Silva, José Capanes, Virgínia Aço, Júlia Lopes, Carmen Ordonez e Alzira Leão.

Conforme A Vida Moderna, muitas companhias teatrais em início de carreira malogravam diante dos obstáculos a serem enfrentados porque não tinham os elementos necessários de estabilidade e duração de um grupo. Entre essas

182 O Pirralho, número 184, 24/04/1915, ano IV.

183 O Monóculo, número 1,12/06/1915, ano I. 
dificuldades estaria o "meio", sempre avesso às tentativas nacionais; a falta de capital, necessário para dar continuidade ao projeto; o repertório "velho"; e os figurinos desgastados de que dispunham para uso. Quanto ao repertório, foi colocado em evidência o fato de serem sempre as "revistas arcaicas" e as "operetas envelhecidas", comumente resumidas por falta de cenário, figurino e por ausência de vozes.

A Companhia Arruda, todavia, conseguiu enfrentar esses obstáculos. Após excursões pelas cidades do interior, mudou-se para a capital, fazendo temporadas nos teatros São Pedro, Colombo e, por fim, instalou-se no Boa Vista, onde realizou mais de mil e oitenta representações - um número bem significativo, consideradas as dificuldades enfrentadas pelas companhias teatrais:

Esse teatro enche-se todas as noites, quer nos domingos, quer nas matinées, quer nas duas sessões da noite, fica literalmente repleto. ${ }^{184}$

As melhores companhias, inclusive as mais ricas e suntuosas companhias estrangeiras, não conseguiam se manter num teatro por mais de dois ou três meses, segundo o artigo. As mais resistentes chegavam aos quatro meses de permanência. A Companhia Arruda, ao contrário dessas, ia completar um ano de trabalho no mesmo teatro. O crítico de $A$ Vida Moderna é categórico ao afirmar que essa façanha só fora possível por causa dos esforços de J. Gonçalves e Abílio de Menezes.

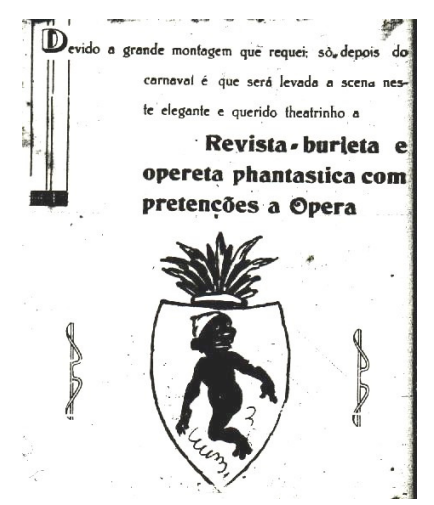

Cartaz da "revista-burleta e opereta fantástica" Saci Pererê (O Pirralho, número 247, 31/01/1918)

184 A Vida Moderna, número 340, 25/07/1918, ano XIV. 
J. Gonçalves, popularmente conhecido como Pery, ficou responsável pela direção da empresa. Homem conhecedor de teatro, colocou sua experiência a serviço do grupo e, ainda, de acordo com o crítico, superou a tarefa mais difícil: disciplinar os atores, os quais seriam sempre indisciplinados.

O grupo era composto de 19 artistas e de 14 coristas. Sebastião Arruda, como elemento principal, personificava o tipo caipira, o "melhor de quantos, no país, tem estudado o tipo caipira", acrescenta o colunista:

Sem recorrer a atitudes e gestos artificiosos, simples, natural, o Arruda encarna o caipira com uma prodigiosa semelhança. ${ }^{185}$

Leopoldo Prata era especialista em representar o cafajeste pernóstico. Celeste Reis possuía a desenvoltura, dançava o maxixe e, portanto, era uma ótima atriz para o gênero revista. Os demais, cada qual com sua habilidade, contribuíram para o êxito da companhia. O corpo de coristas contava com Guilhermina Rodrigues, Alzira Prata, Júlia Doca, Maria Salenda, Irene Dias, Amabile, Theresa Silva, Francisca Rosária, Marina Silva, Estela Bormann, Carmem Ribeiro e Veludo. A parte musical era da responsabilidade de Chagas Junior e Carlos Paiva.

Da fundação da Companhia até o aniversário em questão, foram encenadas as seguintes peças: Uma festa na Freguesia do Ó, 55 vezes; Sustenta a nota, 46; Pausinho, 44; A Capital Federal, 43; Gente Moderna, 33; Uma festa em Guabiroba, 32; Divina Increnca, 30; Sem tirar nem pôr, 27; Mulher soldado, 26; Tintim por Tintim, 25; Picareta, 25; O 31, 25; Caça dotes, 24; Na Piririca, 22; Mambembe, 21; Rosas de N. Senhora, 20; O Recruta do 43, 20; A Grande fita, 20; Pensão de D. Ana, 19; Festa do Divino, 18; Sensitiva, 17; Eu digo a ele, 16; Nhô Zé Maria, 16; Mau jeito, 16; São Paulo em Fraldas, 15; Almirante Negro, 15; Pérola encantada, 14; Na cara do pai, 13; Ribeirão Preto por dentro, 12; Nas horas d'estalar, 11; Periquito, 11; A Grande Avenida, 11; Visconde de Pim Pam Pum, 10; Eleição d'Amor, 10; Off side, 10; Casar para morrer, 10; Não Ihe bulas, 9; Panaché

185 Idem, ibidem. 
Carnavalesco, 9; Manduca Cerimônias, 9; Alegrias do lar, 8; Aliados, 7; Rato 22, 7; Milagres S. Antonio (drama), 6; Candinha, 6; Cá e lá, 5; Espetáculos variados, 5; Milagres S. Antonio (comédia), 3; Quincas Teixeira, 2; Genro do Caetano, 2; A noiva e a égua, 2; 39 da oitava, 2; Entre fidalgos, 2; Cinturão elétrico, 1; Fado e Maxixe, $11^{186}$.

É possível perceber pela extensa lista que a maioria das peças pertencia ao gênero ligeiro e musicado. Considerado o bom desempenho da companhia, comprova-se o quanto esse tipo de peça era bem aceito pelo público.

Danton Vampré, o popular revisteiro paulista, teve algumas de suas peças encenadas pela Companhia Arruda, entre elas São Paulo Futuro, Uma festa na Freguesia do Ó, Sustenta a nota, O Picareta, A Gran Via, A Pensão de D. Ana, O Recruta do 43 e $O$ que o rei não viu.

A respeito de Uma festa na Freguesia do Ó, O Pirralho classificou-a como uma "conchamblance cheia de ditos picarescos e arrojados que os nossos avós não ouviriam com muito prazer". No entanto, não deixou de reconhecer o talento de Sebastião Arruda, afirmando que ele não precisava da claque para receber os aplausos do público e, inclusive, do Pirralho ${ }^{187}$.Mesmo não sendo bem recebida pela crítica, Uma Festa na Freguesia do Ó foi o maior sucesso da Companhia, aliás, a peça que mais vezes foi representada pelo grupo, como mostra a relação acima.

A revista $O$ Recruta do 43 também foi reprovada pela crítica. À exceção do trabalho de Sebastião Arruda, a interpretação dos atores foi motivo de piada para a imprensa.

A interpretação, a despeito de uns erros de concordância e de crase, é boa. O Arruda nas vestes de caipira todo o mundo sabe que é bom memo. Faz rir que é um desperpósito. A Beneventi que na peça tem 174 papéis parece o Fregoli ou a Fátima Miris. Aparece vestida, revestida, travestida, que é um Deus nos acuda. O Chaves Florence, cultivando sempre o velho sestro de não decorar os papéis, dá um trabalhão ao ponto e desaponta até os canastrões que fazem pontas. A Celeste e a

186 Idem, ibidem

187 O Pirralho, número 243, 1ำ quinzena de setembro de 1917, ano VII. 
Maria Amélia muito elegantes e comportadas. A primeira, então, é de uma sobriedade nos maxixes, que deixa a platéia comovida. O Prata não tem na nova revista papel que sobressaia e isso é um mal, porque o valente filho de Niterói, é um dos esteios da verve hodierna. Descendente de Aristófanes e Moliére, o Prata é o Bergson da gargalhada. ${ }^{188}$

$\mathrm{Na}$ segunda quinzena de outubro de 1917, a Companhia encenou $O$ Picareta, O Recruta do 43, Uma festa na Freguesia do Ó, A Gran Via e A Pensão de $D$. Ana. Essa temporada foi muito bem recebida pelo público:

Enchente e mais enchente é o eterno estribilho de todas as crônicas do Boa Vista. Mas valha a verdade: é um teatrinho que merece a bela assistência que tem tido. Vale a pena ver e tornar a ver, e ver mais uma vez e outra mais: - o Arruda no infalível papel de caipira que vem à Capital...artística... ${ }^{189}$

No final de 1917, em novembro, o sucesso do grupo se deu com a representação de $A$ grande fita, de Pedro Monte Ablas. A revista, segundo $O$ Pirralho, era mais séria e mais limpa que suas congêneres, sem pornografias e um passo, mesmo que tímido, para a regeneração desse gênero de teatro ${ }^{190}$.

A imprensa hesitava ante o sucesso da Companhia: ao mesmo tempo em que festejava o êxito do grupo em um meio dominado por companhias estrangeiras, criticava o seu repertório.

Uma das principais queixas dos intelectuais da época, como registramos, devia-se à preferência do público pelas companhias estrangeiras. Valorizar o elemento estrangeiro e se enquadrar nos moldes das civilizações européias era indicativo de progresso e desenvolvimento. Concomitantemente, ansiava-se por firmar uma identidade nacional, e ratificar a posição do Brasil como um país independente. Ou seja, dois sentimentos aparentemente incompatíveis conviviam lado a lado.

188 O Pirralho, $2^{\circ}$ quinzena de setembro de 1917 , ano VII. 189 O Pirralho, número 245, 2o quinzena de outubro de 1917, ano VII. 190 O Pirralho, número 246, $2^{\circ}$ quinzena de novembro de 1917, ano VII. 
Devido a isso, encontram-se, nos periódicos do início do século, críticas favoráveis e desfavoráveis à Companhia Arruda. As desfavoráveis ficam por conta do repertório, composto principalmente pelo teatro ligeiro e musicado; as favoráveis vêem no sucesso da Companhia a valorização do teatro nacional.

A importância da Companhia Arruda, portanto, foi além de sua popularidade junto ao público, já que impulsionou o teatro nacional. Ademais, propiciou a montagem de peças que fortaleceram o movimento nacional-regionalista, cujo intuito era combater a europeização, através da valorização dos elementos nacionais. Esse movimento também resgatava a simplicidade da vida no Interior, como um ideal a ser alcançado com toda sua inocência, em oposição à vida na Capital. E, conforme o mencionado, Sebastião Arruda incorporou o protótipo do caipira ingênuo como nenhum outro.

Além das peças anteriormente citadas, em que Arruda obteve um bom desempenho, vale destacar Cenas da Roça e Flor do Sertão, de Arlindo Leal. Crítico, dramaturgo e jornalista, Arlindo Leal sempre lutou pela valorização do teatro nacional e foi um homem de destaque no meio teatral paulistano:

Flor do sertão está em cena não há ainda duas semanas; mas promete ser, como as Cenas da Roça, uma como nova pedra filosofal para a Companhia Arruda. Todas as noites atrai ao Boa Vista uma multidão de espectadores, que ali vão assistir ao triunfo de Arlindo Leal, dando-Ihe todas as palmas que ele merece pelos seus muitos esforços em prol do levantamento do nosso teatro. ${ }^{191}$

Em janeiro de 1918, a crítica se ocupou da montagem de Mau jeito. A peça valeu pela interpretação dada pela Companhia Arruda, considerou O Pirralho. Segundo seu cronista, o ator não estava no seu meio, mas fazia rir. Leopoldo Prata saiu-se muito bem como um empregado de repartição pública; Maria Amélia, com um olhar brejeiro, agradou a todos; Aurora Tyrana, além de bela, era uma figura imponente no palco, Celeste Reis estava brilhante como atriz-cantora-bailarina; Júlia Lopes, à parte alguns exageros, era uma atriz simpática e sóbria; Raul Soares

191 A Vida Moderna, número 352, 12/02/1919, ano XV. 
e Antonio Dias, que estrearam nessa peça, também colaboraram para o sucesso conquistado pela montagem.

Outra peça, levada à cena na mesma ocasião, merecedora de boas críticas da imprensa foi Sustenta a Nota, de Danton Vampré, Euclydes de Andrade e Juó Bananére. De acordo com Conde Danilo, de O Pirralho:

A interpretação que a companhia dá é cutuba e curruscuba. ${ }^{192}$

Na burleta Gente Moderna, de Francisco Barroso e Nascimento Filho, Arruda encarnou um tipo diferente de caipira: o caipira rico, o qual ainda não fora explorado pelos revisteiros e burletistas. Conforme $O$ Pirralho, a peça, "com ares de alta comédia", foi um dos melhores trabalhos apresentados no Boa Vista ${ }^{193}$.

Mesmo nas peças que não retratavam a vida no Interior, Arruda não se desfazia do tipo caipira. Esse é o caso de A Divina Increnca, de Juó Bananére, uma paródia à Divina Comédia, de Dante Alighieri. Nessa revista, estão em cena Dante e Virgílio, como os dois compadres, sendo que Virgílio é um caipira. O que podia causar um certo estranhamento parece não ter sido levado em conta, tamanho foi o êxito da peça.

Nem todos, contudo, eram simpáticos à excessiva utilização da figura do caipira no teatro. Um crítico de $A$ Vida Moderna ${ }^{194}$, por exemplo, escreveu um texto em forma de protesto, destacando o fato de que o artista brasileiro não concebia outro ambiente a não ser o da fazenda; outro personagem, a não ser o caipira, segundo ele "encardido" e "imbecil"; ou as "nhã-nhãs" doceiras. Ou seja, era sempre o ambiente da roça, com as "sentimentalidades chorosas do sertão". Ressaltou ainda que o Brasil não era feito só de caipiras, mas também de outros perfis à espera de serem explorados. Como exemplo, citou o indivíduo morador da cidade, aquele que tem acesso a outras informações e bens de consumo, cuja vida interior podia ser tão intensa quanto a de um personagem de Hauptman. De acordo com o crítico, ser mais "civilizado", não tornava o personagem menos brasileiro:

192 O Pirralho, número 247, 31/01/1918, ano VII. 193 O Pirralho, número 248, 25/02/1918, ano VII. 
...é preciso que se saiba, que o brasileiro não é só o indivíduo de ponche, barbicha rala e cigarro atrás da orelha. O nosso ambiente não é aquele, que somente vai do córrego ao paiol. E a nossa vida dramática não se restringe às intrigas do Chiquinho Fidêncio. O brasileiro também usa casaca, bebe vinhos caros em cristais de preço, fuma em piteiras de marfim, mora em casas de elevador, e, a sua vida interior é tão intensa, por vezes, como a de qualquer personagem de Hauptman. ${ }^{195}$

No entanto, o brasileiro de que falava o crítico era o protótipo do europeu, e o movimento nacional-regionalista surgiu justamente por querer criar uma identidade nacional distante desse ideal europeizado. Percebe-se que, romanticamente, a imagem do europeu está sempre associada à riqueza, ou seja, também se constrói em cima de um estereótipo. Portanto, o que se tem, tanto do brasileiro quanto do europeu, é uma imagem distorcida da realidade.

A Companhia Arruda colaborou com a consolidação do movimento nacionalregionalista, e, durante os dez anos de sua existência, contribuiu também para a valorização do teatro nacional.

Enquanto a Companhia trabalhava no teatro Boa Vista, o Municipal recebia, na maioria das vezes, companhias estrangeiras. De acordo com o crítico do Correio Musical Brasileiro, o teatro Santana, idealizado pela condessa Penteado, e inaugurado em 1921, contribuiu com a vida teatral paulistana, mas ainda não era o que a cidade precisava. Para ele, São Paulo necessitava de um teatro popular, com ingressos a um preço acessível a todos, "desde o operário humilde até 0 empregado do comércio". Dessa forma, as companhias poderiam defender suas receitas com um preço reduzido, e o teatro não seria privilégio exclusivo de ricos ${ }^{196}$. Ao que tudo indica, a Companhia Arruda conseguiu trabalhar nesses termos, haja vista as informações resgatadas nos periódicos de que o Boa Vista estava sempre cheio, e também o fato de a Companhia ter se mantido no mesmo teatro por um longo tempo.

Um inquérito promovido pelo O Dia perguntou a Cláudio de Souza se havia alguma companhia nacional capaz de representar o Brasil nas festas do

195 Idem, ibidem.

196 Correio Musical Brasileiro, número 1, 1-15 de maio de 1921, pp.11-12. 
Centenário da Independência. Em resposta, o dramaturgo citou a Companhia de Leopoldo Fróes e a Companhia Dramática Nacional, mas não mencionou a Companhia Arruda ${ }^{197}$.

A exclusão da Companhia Arruda revela o preconceito dos intelectuais com o gênero ligeiro e musicado, priorizado em seu repertório.

197 Idem, p. 13 a 15 


\subsubsection{A Companhia Dramática Paulista}

A Companhia Dramática Nacional, anteriormente chamada de Companhia Dramática Paulista, fora organizada por Gomes Cardim, no ano de 1917. Esse acontecimento foi importante para a cidade, pois serviu para marcar presença na vida teatral do país.

O jornal O Furão divulgou a notícia da formação da companhia com entusiasmo, certo de que essa iniciativa estava em boas mãos ${ }^{198}$. Conforme publicado, assim que reuniu uma comissão, Gomes Cardim viajou para o Rio de Janeiro para tratar da parte financeira, sob a responsabilidade de José Loureiro. Foram contratados os seguintes atores, e da seguinte forma:

Primeiras atrizes em igualdade de condições - dama dramática e dama galã: Sras. Itália Fausta e Lucília Peres;

Damas centrais: Sras. Gabriella Montani e Luiza de Oliveira;

Outras figuras femininas: Sras. Marta Castro, Alzira Leão, Davina Fraga e Sophia Guerreiro;

Primeiros atores - galã romântico e galã central: Srs. Antonio Ramos e Alves da Cunha;

Centro: Alves da Silva;

Outras figuras masculinas: Armando Rosas, Joaquim Miranda, Chaves Florence, Victor Palmeira e A. Pinho.

Para o crítico de A Cigarra, com um elenco como esse seria possível "reabilitar o nosso teatro", salvando-o da "decadência"199.

A companhia contava com o amparo do Senador Carlos Campos, José Paulino Nogueira Filho, Nestor Pestana, Luiz Fonseca, Goffredo Telles e Ricardo Figueiredo.

Depois de definida, a Companhia foi trabalhar no Boa Vista, e em maio de 1917, a temporada oficial do grupo encerrou-se.

A formação da Companhia Dramática representou um grande passo para o

198 O Furão, número 93, 17/02/1917, ano III.

199 A Cigarra, número 63, 28/03/1914, ano III. 
teatro brasileiro, principalmente para aqueles que o consideravam "decadente". Via-se na sua fundação a esperança para a valorização, ou criação, do teatro nacional:

O reerguimento do teatro nacional - digamos antes a criação do teatro nacional, que o que por aí existe com esse nome não são senão os primeiros materiais dispersos de uma obra cujos verdadeiros fundamentos estão por ser lançados - a criação do teatro nacional tem sempre oscilado entre os aéreos ideais de alguns escritores sem sorte e as especulações de alguns empreendedores sem ideais. ${ }^{200}$

A iniciativa de Gomes Cardim, no entanto, era uma tentativa séria e sensata, assegurava o crítico de $A$ Cigarra. Sem autores que vislumbravam somente o sucesso, desconsiderando o teatro nacional, e sem empresários que visavam somente ao lucro. Para dar certo, bastaria que o público paulistano soubesse apreciar o trabalho desses artistas e compreendesse o "alcance moral desta empresa", caracterizada como uma "obra de patriotismo"201.

Segundo Tobias Monteiro, o objetivo era constituir uma Companhia permanente que proporcionasse, todos os anos, uma série de bons espetáculos, valorizando as peças nacionais ${ }^{202}$. Entretanto, como seu repertório não se compunha exclusivamente de peças brasileiras, o crítico de $O$ Echo ficou inconformado ao deparar-se com o cartaz de estréia anunciando La Flambée $e^{203}$. A Cigarra achou compreensível que a Companhia também encenasse peças estrangeiras, uma vez que precisava se manter financeiramente. Além disso, destacou que não seria possível esperar por originais brasileiros, posto que seu número era muito reduzido. Esses problemas, observou, poderiam atrapalhar o fim almejado, ou seja, a valorização - ou criação - do teatro nacional.

Outra censura de $O$ Echo referiu-se à formação do elenco, misto de atores brasileiros e estrangeiros. Tobias Monteiro, porém, não considerou isso um problema, e afirmou que com o tempo Gomes Cardim poderia unir-se a Coelho

200 A Cigarra, número 62, 14/03/1917, ano III.

201 Idem, ibidem

202 Revista do Brasil, número 17, maio de 1917, ano II, Vol. V, pp. 109-111.

203 O Echo, número X, abril de 1917, ano XV. 
Neto, diretor do Conservatório Dramático, a fim de aproveitar os talentos entre os estudantes do instituto ${ }^{204}$.

A peça escolhida para a estréia do grupo foi La Flambée, de Kistermaecker. O Pirralho noticiou que o teatro estava cheio, e que foi um prazer verificar o bom resultado da iniciativa de Gomes Cardim. Os elogios direcionaram-se à interpretação dos atores, mas foram feitas ressalvas ao figurino e ao cenário. Sobressaíram-se os trabalhos de Antônio Ramos, Alves da Silva e Alves da Cunha. Itália Fausta e Alzira Leão mereceram destaque à parte:

Senhoras de seus papéis, houveram-se ambas com galhardia, merecendo os calorosos aplausos que o público Ihes dispensou. ${ }^{205}$

Apesar de o grupo estar trabalhando "de vento em popa" - de acordo com expressão em voga na época - o público ainda não se mostrava convencido de que uma companhia nacional pudesse fazer arte, observou o cronista de O Pirralho:

O povo, essa entidade incompreensível e invisível, mas que existe de fato, é que ainda não se convenceu de uma trupe indígena, que faz suas coisas em matéria de arte. $^{206}$

Aproveitando o bom momento, Lucília Peres organizou uma festa artística, na qual representou o gran guignol Beijo nas trevas. Para o crítico de O Pirralho, havia algo de "refinadamente doentio e besta" na peça. Conforme narrou, logo na entrada do teatro, sentia-se um cheiro de formol, de arsênio, de éter, prevendo que o espetáculo seria uma "droga". O ator que fez o papel do amante da protagonista, vivida, é claro, por Lucília Peres, não se saiu muito bem. Na verdade, o crítico salientou que ele fez todos os esforços para sair-se mal.

Lucília Peres esteve bem, mas gritou muito e exagerou no tom de ingenuidade dado ao personagem, segundo $O$ Pirralho. No ato de cabaré, a atriz

204 Revista do Brasil, artigo citado.

205 O Pirralho, número 233, 27/03/1917, ano VI.

206 O Pirralho, número 234, 20/04/1917, ano VI. 
mostrou-se graciosa, mas não foi suficiente para que o público esquecesse os gritos e retomasse a interpretação exagerada.

Poucos meses após a fundação da Companhia, a cidade prestou uma homenagem a Gomes Cardim, por ter levado adiante um projeto de tamanha dificuldade, como a de organizar uma companhia dramática nacional207. A princípio, ninguém acreditava no seu sucesso, pelo contrário, apostavam no seu fracasso. No entanto, durante dois meses e meio, a Companhia Dramática de São Paulo conseguiu manter-se em cartaz sem subvenção oficial, conquistando crítica e público. Mas para que esse fosse apenas o primeiro passo para a valorização do teatro nacional, como alguns supunham, eram necessárias outras medidas, tais como o apoio governamental e o do público.

$\mathrm{Na}$ temporada do teatro Boa Vista, foram encenadas as seguintes peças: Mancha que Limpa, de Echegaray ${ }^{208}$; A Ré Misteriosa, de Bisson; A Bela Madame Vargas, de João do Rio; A Virgem Louca, de Henri Bataille; Nó Cego, de João Luso; O Diletante, de Martins Pena; Uma Senhora llustrada, de Artur Azevedo, Perdão que Mata, de Oscar Guanabarino; e A Caipirinha, de Cesário Mota, conforme Miroel Silveira ${ }^{209}$.

Tobias Monteiro registrou que $A$ Caipirinha foi o maior triunfo da Companhia Dramática de São Paulo na temporada ${ }^{210}$. Apesar da fragilidade do texto teatral e da má atuação dos artistas, a montagem agradara muito porque o público estava sedento de nacionalismo e cansado de peças estrangeiras:

É uma peça que não resiste a uma crítica severa. Os seus defeitos saltam aos olhos mais inexperientes e para agravá-los houve ainda o concurso dos intérpretes que, embora artistas estimáveis alguns, estavam na impossibilidade física de reproduzir com perfeição os nossos tipos da roça. ${ }^{211}$

O enredo da peça gira em torno de Maroca, a Caipirinha. Após a morte de

207 O Pirralho, número 239, 22/06/1917, ano VI.

208 Em A Cigarra, número 66, 19/05/1917, ano IV, a informação é que a peça Mancha que Limpa é de Oscar Guanabarino.

209 SILVEIRA, Miroel. Op. cit. p.168.

210 Revista do Brasil, número 17, maio de 1917, ano II, Vol. V, pp. 109-111

211 Revista do Brasil, artigo cit.. 
seus pais, a menina fica sob os cuidados de seu avô, Pedro. No entanto, com a alegação de que Maroca encontra-se órfã e desamparada, Tonico Silvinha questionará sua tutela, que será posteriormente entregue a Ricardo, cunhado de Silvinha. Maroca e Silvinha cresceram juntos, mas separaram-se quando ele foi estudar fora. No seu regresso, o rapaz voltou mudado, portava-se agora com modos diferentes e inconvenientes, como declarou a Caipirinha, em tom confidencial, a seu primo Juca.

Maroca, após ser obrigada a deixar seu avô, é levada à casa de Ricardo e Genoveva, sua esposa. O casal passa a tratá-la como criada.

No segundo ato, já em casa de Ricardo, ele e a esposa resolvem sair e deixam a menina sozinha. Sabendo disso, Silvinha pula a janela da casa e a agarra à força. Nesse momento, aparece Juca, pronto a defendê-la do ataque. Livres de Silvinha, ambos decidem fugir. Assim que saem da casa, o local está cercado pela polícia, e Juca é preso. Ricardo e Genoveva chegam, no mesmo instante, e, revoltados com a confusão, expulsam Maroca de casa, mas a garota é presa também.

Pedro, desesperado desde que a neta se fora, tenta arranjar uma forma de tê-la novamente sob sua guarda. Quando já perdera a esperança, eis que surge a garota fugida da polícia. Logo em seguida, chegam os soldados para levá-la de volta e começam a discutir com Pedro e seus companheiros. No momento em que os soldados preparam-se para atirar, aparece Gonçalo, o oficial de justiça, juntamente com Juca, e Ihes comunica que o juiz dera permissão para que Maroca se casasse com Juca. Dessa forma, a Caipirinha não estaria mais sob responsabilidade de Ricardo e poderia viver junto de seu avô e do seu primo, o qual sempre gostara dela.

O crítico de $A$ Cigarra escreveu que essa peça foi uma revelação para o público paulista, que nunca suspeitara do talento de Cesário Mota para a comédia. As falhas da peça não passaram despercebidas ao crítico, no entanto os elogios encobriram-nas:

...a peça, à parte inevitáveis senões, era bem feita, era viva e graciosa, e estava 
cheia de observação justa e flagrante; interessava, comovia e fazia rir. E era inteiramente, profundamente paulista. ${ }^{212}$

O comentário final ilustra o que observamos anteriormente sobre a necessidade de elevar a cidade de São Paulo ao patamar de centro artístico do país.

No início de 1918, a Companhia Dramática de São Paulo já passara a se chamar Companhia Dramática Nacional. Mesmo tendo boa repercussão em São Paulo, a cidade ainda não possuía a vida teatral do Rio de Janeiro; por isso Gomes Cardim e Itália Fausta decidiram se estabelecer na Capital Federal, e a Companhia, de Paulista, passou a Nacional.

Em 24/06/1920, Gomes Cardim voltou a ser notícia. Dessa vez, a imprensa destacava a montagem da opereta $O$ Tesouro da Feiticeira, escrita por ele e musicada pelo maestro Antonio Candido. A peça foi levada à cena, no dia 17 de junho, por um grupo de amadores. A renda do espetáculo seria revertida em benefício do Hospital das Crianças da Cruz Vermelha Brasileira. Sobre a peça, $A$ Vida Moderna trouxe o seguinte comentário:

O libreto gira em torno da "História da Carochinha" e foi muito bem cuidado pelo seu autor que soube concatenar com habilidade todas as cenas, algumas delas de bastante intensidade dramática e outras cômicas como requer o assunto. ${ }^{213}$

O papel da protagonista ficou a cargo de Virgínia Romano, que o desempenhou com desenvoltura. A "feiticeira" foi interpretada por Hermínia Russo. Também fizeram parte do elenco Maria de Lourdes Ribeiro, Thomas Mauger, Felisbina e José Ribeiro, Georgina Hubenet e Armando de Queiroz.

212 A Cigarra, número 66, 19/05/1917, ano IV.

213 A Vida Moderna, número 385, 24/06/1920, ano XVI. 


\subsubsection{Itália Fausta}

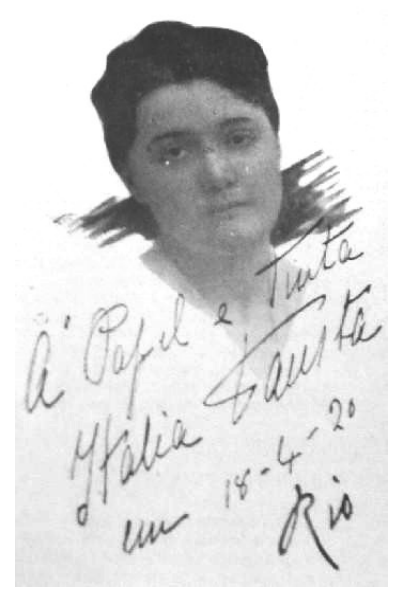

Itália Fausta (Papel e Tinta, número 6, fevereiro de 1921, ano I.)

Itália Fausta, como se sabe, começou a trabalhar como atriz com os filodramáticos. Diante do destaque obtido, passou a atuar como profissional, e buscou inspiração na trágica italiana Eleonora Duse. O grande papel de sua carreira, aquele pelo qual ela seria sempre lembrada, foi interpretado pela primeira vez com a Companhia Dramática Paulista. Trata-se de A Ré misteriosa, de Bisson.

Carneiro Leão registrou que para apreciar o trabalho da atriz e compreender a sua força dramática bastaria assistir ao segundo ato da peça de Bisson. Nele a atriz mostrava todo o seu talento nas cenas veladas e trágicas:

...para sentir o vigor e a expressão da sua arte, bastam aquelas cenas veladas, aquela tragédia, quase silenciosa, o paroxismo sem explosões da angústia sem termo daquela mulher, que errava, como uma sombra sinistra, em grande parte do segundo ato da peça dramalhão de Bisson. ${ }^{214}$

Segundo o crítico, não haveria, em língua portuguesa, atriz com maior vigor dramático e melhor expressão artística. Sua interpretação já chamara a atenção nas representações do Teatro da Natureza, em que soube representar muito bem os personagens da tragédia grega, como Fedra e Antígone. Todavia, a atriz teria se superado mesmo no papel de Jaqueline, de $A$ Ré Misteriosa, produzida pela

214 A Cigarra, número 64, 18/04/1917, ano IV. 
Companhia de Gomes Cardim, no qual ela esteve "irrepreensível".

A Cigarra, em edição de 31/05/1917, publicou, como homenagem da revista, uma foto da atriz. O comentário seguinte à foto informa-nos que essa demonstração de apreço devia-se à graça irradiante de sua pessoa, o seu poder de altiva sugestão e a fama que Ihe aureolava o nome, há muito já consagrado no Brasil e em Portugal. O sucesso da Companhia Dramática Paulista, inclusive, deuse, em grande parte, por causa da atriz, que não teria rival no drama:

É sempre empolgante, dominadora. Às vezes, chega a ser extraordinária, atingindo o limite da emoção, o grifo agudo do sofrimento, o peso enorme da dor que ela sente, exterioriza e encarna, com uma força que imprime a realidade, a opressão formidável das grandes tragédias humanas. ${ }^{215}$

Antes que La femme $X$ fosse traduzida como $A$ Ré Misteriosa, a peça recebeu o nome de $A$ mulher dez, de acordo com $O$ Pirralho. Porém a revista preferiu chamá-la de $A$ mulher incógnita, uma vez que $\mathrm{X}$ representa uma incógnita na matemática. Desconsideradas as brincadeiras, o periódico publicou que a peça fora um sucesso, sendo a atriz, merecidamente, muito aplaudida ${ }^{216}$.

Itália Fausta, em 1920, concedeu uma entrevista ao periódico Papel e Tinta $^{217}$. Em conversa com o repórter, ela falou um pouco sobre seu cotidiano e sua carreira. A atriz, segundo descreveu o entrevistador, foi a artista mais representativa do teatro nacional, consagrada dentro e fora do país. Abençoada por Historion, o pai do teatro - que a mantinha encantada - conhecia profundamente o segredo das paixões humanas, sendo, portanto, uma mestra da emoção. Não haveria rivais para a atriz no continente americano. Seu maior aprendizado viera da vida, daí a sua naturalidade, fosse na representação física, fosse na representação moral de um personagem. O espírito observador, o perfil de mulher estudiosa e honesta para com sua profissão a diferenciava de atores improvisados e medíocres. Dessa forma, dando vida ao personagem de uma forma

215 A Cigarra, número 67, 31/05/1917, ano IV. 216 O Pirralho, número 234, 20/04/1917, ano VI. 217 Papel e Tinta, número 1, 31/05/1920, ano I, pp. 31 e 32. 
consciente, a atriz dominava a platéia, interpretando $A$ Ré Misteriosa, Thereza Raquin, A Mãe, entre outras.

A entrevista, realizada no Teatro República, onde Itália Fausta estava prestes a estrear um novo trabalho, não teve como foco o seu amor à arte e a consagração da sua vida a esse ideal. O intuito era revelar aos leitores um outro lado da atriz, aquele fora dos palcos. Sendo assim, a primeira pergunta foi sobre qual seria sua ocupação favorita fora dos palcos. Ao que a atriz respondeu ser a tarefa de domesticar pássaros:

São eles a distração mais encantadora da minha vida íntima e por isto lhes voto uma dedicação e um afeto único. ${ }^{218}$

Continua a atriz, indicando o seu pássaro mais manso:

-Vê quanto é manso; porém os pássaros, como tudo na vida, têm as suas alternativas e apenas os deixo para alguma turnê, esquecem a sua dona e, com ela, as lições que Ihes dera. ${ }^{219}$

Questionada sobre sua vocação artística, Itália Fausta relembrou o início de sua carreira. Fora em São Paulo, aos nove anos de idade, interpretando um papel de ingênua, em um dramalhão, que a menina brilhou dentro de um vestido de noiva de imensa cauda. Mais tarde, perante o mesmo público, apresentou-se no teatro Santana, em um espetáculo organizado pela família Prado, em benefício do autor Eugênio de Magalhães. A peça se chamava Pinto, Leitão \& Companhia. Miroel Silveira observou que, em apontamentos deixados pela atriz, a sua peça de estréia teria sido Gioconda, de D'Annunzio, interpretando o papel da menina "Beata". Em seguida, teria se apresentado no Santana, fazendo o papel da menina Totó, na peça Zazá, de Berton, ao lado da famosa atriz Réjane ${ }^{220}$.

218 Idem, ibidem

219 Idem, ibidem

220 SILVEIRA, Miroel. Op. cit. p. 70. 
Entretanto, na entrevista cedida a Papel e Tinta, Itália Fausta considerou que sua carreira só teve início de fato após estudar durante quatro anos no Conservatório, sob a direção de Gomes Cardim. Esse curso the corrigira as exuberâncias interpretativas, a sua dicção, os seus gostos estéticos e, utilizando-se de seus dotes naturais - modesta, a atriz põe em duvida se os tinha -, Gomes Cardim norteava-a para uma superior orientação artística. Posteriormente, uma viagem à Europa completou a sua formação e pôde considerar-se uma atriz, porém, ainda não triunfadora, como desejava.

Quanto ao seu temperamento artístico, a atriz se considerava uma mulher de sentimentos, mas que não se envaidecia com os aplausos do público:

Nunca me envaideceram, nem os anelei, nem menos me esforcei para arrancá-los. Em cena só me preocupo com a interpretação do meu papel, de compenetrar-me das paixões e da personagem, a fim de poder dar, assim, uma visão clara e precisa da realidade. De mais nada. ${ }^{221}$

Sobre o trabalho dispensado a cada estréia, Itália Fausta afirmou não ser possível fazer nada sem um mínimo de esforço, principalmente quando se pretende realizar um trabalho honesto e se ama a arte sinceramente, sem ter 0 mero intuito do lucro. Em seu gabinete de trabalho, estudava seus papéis, recostada numa rede e abstraída do mundo. Os seus favoritos eram os das mulheres perversas. Todos os caracteres malvados, os impulsivos, e os escravos das mais abjetas paixões, identificavam-se mais com seu temperamento, confessou a atriz. No entanto, fez questão de ressaltar que os seus sentimentos eram totalmente contrários a esses.

Quando o assunto rumou para sua vida íntima e feminina, a atriz se retraiu, pois considerou a pergunta indiscreta, e fez um vago gesto de enfado, segundo o entrevistador. Em seguida, afirmou que de intimidade só lhe podia dizer que, em sua vida, o mais emocionante era a arte e os pássaros.

A entrevista chegava ao fim, mas ainda havia uma pergunta: "E o minuto

221 Papel e Tinta, artigo cit. 
mais interessante de sua vida?". O repórter queria saber se havia sido sua estréia ou quando recebera a consagração do seu talento fora da pátria. Itália Fausta respondeu:

-Nenhum desses, absolutamente nenhum. Esse minuto realmente... ainda não chegou para a minha vida e espero-o com a ilusão de que talvez chegue, ainda que então sejamos menos alegre porque deixou de ser um sonho lisonjeiro...222

222 Idem, ibidem. 


\subsubsection{Leopoldo Fróes}

Leopoldo Fróes foi um dos atores mais importantes do início do século XX. Tendo construído sua carreira no Rio de Janeiro, fez excursões por todo o país, e pelo exterior, com sua Companhia. Elogiado pela crítica e querido pelo público, privilegiou a montagem de textos teatrais que se afastavam do gênero musicado, tais como Flores de Sombra, Outono e Primavera, ambos de Cláudio de Souza; Longe dos olhos e Nossa Terra, de Abadie Faria Rosa; Os sonhos de Teodoro, de Gastão Tojero; Delicioso Casamento, de Guitry; As doutoras, de França Junior; $A$ Dama das Camélias, de Dumas Filho.

Em 1915, O Pirralho anunciava para breve a estréia da Companhia formada por Lucília Peres e Leopoldo Fróes. A atriz, que posteriormente integrou a Companhia Dramática Paulista, convidara Fróes para fazer parte de sua Companhia, mas, com o passar do tempo e o prestígio alcançado pelo ator, já não havia espaço para duas estrelas no mesmo grupo. Lucília queria montar peças em que fosse a protagonista, e Leopoldo, que não se contentava mais com um papel de segunda importância, também queria ser o ator principal do espetáculo. Dessa forma, a solução encontrada foi cada um ter a sua própria Companhia, e separaram-se.

A peça que acompanhou Leopoldo Fróes em quase todas as suas temporadas foi Flores de Sombra, de Cláudio de Souza. Sempre que nas turnês o público começava a rarear, Flores de Sombra subia à cena e o teatro ficava novamente repleto. Era a tábua de salvação da Companhia de Leopoldo Fróes. A peça foi montada pela primeira vez pela companhia do ator em dezembro de 1916 e, como já mencionamos, remontada em diversas ocasiões. Nessa mesma temporada, no teatro Boa Vista, foi encenada a comédia O Velho Amigo, de F. Garrido, muito elogiada pela crítica, tanto em relação ao texto quanto à interpretação dos atores:

O trabalho do saudoso escritor é cheio de magníficos trocadilhos e piadas que 
trazem a platéia em constante hilaridade..$^{223}$

Os atores representaram muito bem os seus papéis. A atuação de Eduardo Pereira foi a única que desagradou. Tina Valle soube aproveitar seu pequeno papel, mostrando-se estudiosa e capaz de substituir a atriz anterior com vantagem, anunciou $O$ Pirralho.

Em janeiro de 1920, a Companhia estreou Longe dos Olhos, de Abadie Faria Rosa, com o teatro completamente cheio. Dessa montagem, participaram Leopoldo Fróes, Amália Capitani, Gabriela Montani, Sylvia Bertini, Berthe Barone, Átila de Moraes e Carlos Torres. A Vida Moderna publicou que a estréia não poderia ter sido mais "auspiciosa"224. O grupo seguiu até março no teatro São José, quando se despediu de São Paulo, deixando uma ótima impressão para a impressa paulistana. Já no final da temporada, Amália Capitani saiu da Companhia, e em seu lugar entrou Alice Ribeiro. Foram levadas à cena, nas últimas semanas, as peças Champignol à força, "engraçadíssima comédia traduzida do francês, na qual Leopoldo Fróes faz o impagável papel de Luciano"; Flores de Sombra, de Cláudio de Souza; Delicioso Casamento, de Sacha Guitry; e A idéia de Franz. A conselho de seus médicos, Leopoldo Fróes precisou interromper seu trabalho, por motivos de saúde, mas antes realizou sua festa artística, montando, em despedida, O Barbeiro de Sevilha ${ }^{225}$.

Quando o assunto era a valorização do Teatro Nacional, o nome de Leopoldo Fróes fazia-se presente. Claudio, de A Vida Moderna, escreveu o artigo "O Teatro Nacional", em que reclamava que o nosso teatro, desde João Caetano, vivia numa ânsia de formação ${ }^{226}$. Segundo ele, só nos restavam as "imbecilidades" das revistas de ano, uma ou outra peça sofrível, atores de quarta ou quinta ordem fazendo um teatro "caquético e imbecil". Esse quadro, porém, começou a se modificar quando surgiu Leopoldo Fróes, "o reconstrutor das ruínas de nosso teatro". Nas palavras de Claudio, o ator era um psicólogo e artista, possuía talento,

223 O Pirralho, número 230, 13/01/1917, ano Vl. 
elain e savoir-faire. Psicólogo, porque os papéis, representados por ele, ganhavam um cunho de realidade psicológica. Por esse estilo personalíssimo que suas interpretações tornaram-se célebres, continuou o articulista. Os escritores de talento, sentindo haver um artista capaz de interpretar as suas criações, puseramse a escrever "peças encantadoras", interessantes, "com psicologias em cena, com a sua moral, a sua filosofia, a sua urdidura, o seu desenlace e a sua beleza".

Em 1920, a revista Papel e Tinta publicou uma entrevista com Leopoldo Fróes $^{227}$. Na seção "Nossos artistas na intimidade", tal qual Itália Fausta, o ator falou um pouco sobre sua vida pessoal, sobre sua carreira e o Teatro Nacional.

A entrevista começou destacando as qualidades do ator, descrito como uma das figuras mais brilhantes do teatro brasileiro, como também uma das mais simpáticas e prestigiosas, cujo prestígio fora avaliado por pessoas conhecedoras do assunto. Segundo o entrevistador, admirável fora sua atitude de largar uma carreira de "doutor" - Leopoldo Fróes formara-se em Direito - em um país em que um diploma era sinônimo de status, para entregar-se à vida teatral. No entanto, o amor à arte, mais do que o talento teria sido o impulso que o levara ao teatro. Como advogado seria mais um entre tantos, como ator era uma das figuras de maior relevo na cena nacional.

Como ator e empresário teatral, conseguiu uma situação financeira estável, conquistando uma independência econômica para si e sua Companhia, o que possibilitou a realização de uma turnê pelos Estados do Sul do Brasil. Na véspera de sua partida para o Sul, Leopoldo Fróes concedeu essa entrevista à revista. Em seu camarim, ele tocava uma guitarra, "cantando à meia voz uma modinha riograndense". Quando o jornalista pediu-Ihe que falasse um pouco sobre sua vida, seu passado, respondeu:

-Evocar reminiscências é sempre triste. É o consolo dos velhos e eu, como vê, estou em pleno...apogeu juvenil... ${ }^{228}$

Mesmo depois dessa resposta, o jornalista insistiu e perguntou se era 227 Papel e Tinta, número 3, julho/1920, ano I. 
verdade que 0 ator ingressara no teatro por amor. Fróes disse que era tudo mentira, e que não sabia a origem de tal lenda. O que o levara mesmo ao teatro, fora uma inclinação natural; desde pequeno tinha um grande prazer em recitar poesias. O ator, segundo a entrevista, já recebia inúmeros aplausos desde os "forrobodós" de Niterói, quando recitava a poesia $A$ morte galante. Sua vocação para o trágico fora descoberta na encenação do drama histórico O Rei Maldito, já como artista profissional.

Como companheira de arte, sua atriz preferida era Ângela Pinto. Fora de cena, comentou - em tom de brincadeira - que, com o belo sexo, gostava de conversar sobre política internacional, assunto sobre o qual as mulheres teriam um critério menos vulgar. Galã da época, ele contava com muitas fãs, e confessou que os papéis que mais lhe entusiasmavam na hora de representar eram aqueles mais simpáticos às mulheres. Porém, prossegue o repórter, foi interpretando o coveiro, em Hamlet, em Portugal, que teve o maior êxito de sua carreira, um de seus maiores triunfos.

O momento mais feliz da sua vida particular foi quando recebeu o título de doutor, posto que nunca mais teria que estudar Direito. Voltando ao campo teatral, o jornalista quis saber qual o papel que Fróes representou com mais carinho. Ele respondeu que foram todos os papéis, pois em todos colocava uma boa dose de sinceridade. Com certa dose de ironia, o repórter comentou: "Dizem por aí que você tem notada tendência para colaborar com os autores...". Prontamente, Leopoldo Fróes respondeu: “-Dizem, não. Fui e continuarei a ser o colaborador obrigado, pelo menos nas obras que representei".

Um dos mais conhecidos episódios a respeito disso, foi quando Cláudio de Souza entrou com uma petição na justiça contra Leopoldo Fróes, por causa de mudanças no texto feitas pelo ator. A esse gesto, ele alegou ter colaborado com Cláudio de Souza na redação da peça. No entanto, quando a peça foi publicada em livro, o dramaturgo fez questão de inserir uma nota, observando que a peça fora inteiramente escrita por ele, sem a colaboração de outra pessoa.

No final da entrevista, o jornalista pergunta qual a opinião do ator sobre 0 Teatro Nacional. Sua resposta é que mais tarde o progresso do teatro será uma 
realidade, mas para isso será necessário que bons autores e intérpretes não poupem nenhum sacrifício em prol desse ideal.

Em seguida, o repórter, sob o pseudônimo Xenius de Pacotilla, faz um balanço da entrevista. Sua conclusão - em que se percebe um leve tom satírico - é que, em Leopoldo Fróes, o homem e o artista se completam. Conhecendo-se o ator em cena, conhece-se o "doutor Fróes". A vida fora de cena, para ele, é uma continuação dos convencionalismos daquela. Temperamento boêmio e quixote, ele está sempre correndo atrás de novas aventuras para seu deleite espiritual. Na vida amorosa, à fidelidade burguesa, prefere os encantos da volubilidade da vida a sós.

$\mathrm{Na}$ arte, Leopoldo Fróes tinha o defeito de ser demasiado eclético, continua o entrevistador. Para ele não havia diferença em interpretar uma fina comédia do moderno teatro francês ou espanhol, um drama de lbsen, uma tragédia de D’Annunzio, ou fazer o público dormir recitando uma banal obra portuguesa. Seu talento de intérprete lucraria muito mais se ele resolvesse se dedicar a um só gênero, assim também contribuiria com a arte no país.

O repórter retomou, nesse momento, o mesmo lamento sobre a "decadência do teatro nacional". Como já abordamos anteriormente, entre as várias causas responsáveis por esse problema estaria a ganância dos empresários que só visavam ao lucro. Em relação a isso, Xenius de Pacotilla, aconselhou o "doutor Fróes" a se voltar mais à arte nacional:

Esta seria uma orientação eficaz porque Fróes, com o seu espírito tendente a especulações materiais, poderia levá-lo a realizar uma obra que até agora ainda está por fazer-se, organizando uma companhia com elementos capazes de secundá-lo, e todos eles homogêneos, no que primam os atores nacionais, ainda que fosse somente para levantar a sua nova moral. Que seja assim. ${ }^{229}$

229 Idem, ibidem. 


\subsection{A evolução do teatro considerado sério}

J. Galante de Sousa informa-nos que, ansiosos por um movimento de renovação do nosso teatro, alguns autores empenharam-se em batalhar pela "boa causa" e lutaram por esse ideal, que se concretizou por volta de 1920. Gomes Cardim, Coelho Neto, Cláudio de Souza e João do Rio, como observamos na nossa pesquisa, uniram-se em prol desse objetivo.

O fortalecimento do nosso teatro e o renascimento da comédia de costumes surgiu, pois, a partir desse movimento, cuja preocupação era dar impulso ao sentimento nacionalista, com peças como Onde canta o sabiá, A Juriti, Terra Natal e outras ${ }^{230}$.

O historiador chamou a atenção para alguns fatos que marcaram esse movimento de renovação. O Teatro da Natureza, idealizado por Alexandre Azevedo, tendo Itália Fausta à frente do elenco, realizou uma série de espetáculos ao ar livre, no Campo de Santana, no Rio de Janeiro. No entanto, essas apresentações foram, em parte, prejudicadas pela chuva, e o projeto não foi adiante. A inauguração do Trianon, no Rio de Janeiro, em 1915, pela Companhia Cristiano de Souza, privilegiou a montagem de originais brasileiros e favoreceu o teatro nacional. No ano de 1917, à empreitada de Gomes Cardim, com a Companhia Dramática Paulista, juntou-se o bem sucedido trabalho de Leopoldo Fróes e Alexandre Azevedo. Finalizando essa série de esforços a favor do teatro nacional, em 1921, surgiu a Companhia organizada por Viriato Correia, Nicolino Viggiani e Oduvaldo Vianna, tendo Abigail Maia como atriz principal.

Em abril de 1917, a Companhia Cristiano de Souza instalou-se no teatro São José, onde realizou uma temporada que recebeu boas críticas de $O$ Pirralho:

Este ator que no meio da pacovice de teatro nacional sempre descobre margem para organizar bons conjuntos não precisa que the façamos reclame. Basta apenas que citemos os nomes de Abigail Maia, Augusto Campos e Pepa Ruiz, além do seu, que é nome feito entre os que no Brasil cultuam a boa arte, para que definamos o valor 
da gente que trabalha no S. José. ${ }^{231}$

O cronista prosseguiu tecendo elogios a Abigail Maia. A atriz, segundo a crítica, apresentava-se como criadora da admiração paulista, pois já estávamos acostumados a apreciá-la, desde o seu agradável timbre de voz até a "maleabilidade de sua palestra viva e cintilante". No número seguinte da revista, os elogios direcionaram-se novamente à atriz: "A atriz Abigail Maia só por si vale um sucesso". Mas, dessa vez, a nota traz um comentário desfavorável a Cristiano de Souza. D. Métrio, pseudônimo do cronista, observou que a trupe se ressentia da falta de um chefe que falasse alto, pois Cristiano não conseguia "ralhar com o seu pessoal endiabrado" - ao que parece faltava maior organização na Companhia.

Alexandre Azevedo foi figura constante nos palcos brasileiros desse período. Em 1913, estreou, no Palace Theatre com a companhia portuguesa, da qual fazia parte Adelina Abranches. Foram representadas as peças $A$ menina do chocolate e Garoto de Lisboa. O ator, apesar de ser português, trabalhou por muito tempo no Brasil.

No início de 1917, aproveitando o sucesso de Flores de Sombra, Alexandre Azevedo montou uma nova peça de Cláudio de Souza, A Renúncia. A crítica não foi favorável à interpretação dada pela Companhia. Se Cremilda de Oliveira, Alexandre Azevedo e Antonio Serra saíram-se bem na interpretação de seus papéis, "o resto da companhia foi desastrado" 232 . De acordo com Aldinio Jurema, o texto de Cláudio de Souza fora castigado pelos atores.

Em 21 de julho de 1921, Alexandre Azevedo estreava com nova companhia no teatro Phenix, no Rio de Janeiro. A imprensa aguardava com ansiedade essa apresentação, pois Alexandre Azevedo havia contratado dois novos artistas em São Paulo: o ator Carrara e sua esposa, Electra Carrara. Além deles, completavam o elenco: Judith Rodrigues, Davina Fraga, Amélia Trajano, Olga Barreto, Carmem Marques, Ferreira de Souza, Oscar Soares, José Soares e Barreto. O espetáculo de estréia foi Carreira Florida, três atos do próprio Alexandre Azevedo, que já

231 O Pirralho, número 234, 20/04/1917, ano VI. 232 O Echo, número IX, março de 1917, ano XV. 
alcançara sucesso de crítica e público quando apresentado em São Paulo. Em seguida, seria apresentada a peça Tancredo Maluco, uma comédia nova e "engraçadíssima”, segundo O Correio Musical Brasileiro ${ }^{233}$. A Companhia anunciara que o repertório a ser apresentado seria constituído, principalmente, de originais brasileiros.

Também no Rio de Janeiro, anunciava-se para 8 de julho a estréia, no Cine Teatro América, da Companhia de comédias e burletas, organizada pelo ator Antonio Sampaio, tendo como primeira figura a atriz Alzira Leão. O elenco se completava com Medina de Souza, Carmem Fernandes, Yvone Costa, Diola Silva, Oswaldo Novaes, Antonio Barbosa, Raul Gonçalves, Ernesto Cardoso, Jaime Pereira, Eugênio Carvalho e o maestro Amphróquio de Sá. A peça a ser representada seria Cabocla de Caxangá, de Gastão Tojero ${ }^{234}$.

A dramaturgia nacional, sempre desacreditada pelos críticos, ganhou um impulso com a apresentação de Flores de Sombra, que fortaleceu o movimento nacional-regionalista, como já vimos. Nessa mesma linha foram apresentadas $A$ Caipirinha, Cabocla de Caxangá, A Juriti e O Contratador de Diamantes - essa última na linha nacional não regional. Cláudio de Souza também escreveu, entre outras, A Renúncia, montada pela Companhia de Alexandre Azevedo; e Outono e Primavera, levada à cena por Leopoldo Fróes.

Em 1916, a imprensa ocupou-se bastante das peças Mon Coeur balance e Leur Âme, de Oswald de Andrade e Guilherme de Almeida. Outro autor que se destacou e teve peças apresentadas no início do século XX foi João do Rio. A representação de Eva mereceu um artigo de Oswald de Andrade, em O Pirralho.

Na divisão da história do Teatro no Brasil proposta por J. Galante de Sousa, o período conhecido como a "decadência do teatro brasileiro" abrange o final do século XIX e os primeiros anos do século seguinte. No que diz respeito ao século XX, denominado de "Teatro Contemporâneo", a primeira fase, especificamente antes de 1920, o historiador chamou de "Renovação do teatro nacional". A comédia de costumes de autores como Abadie Faria Rosa, Viriato Correia e Oduvaldo 
Viana; e o trabalho das empresas dramáticas de caráter nacionalista (Teatro da Exposição), Eduardo Vitorino, Leopoldo Fróis, Gomes Cardim, Oduvaldo-ViriatoCorreia-Nicolino Viggiani marcariam esse momento ${ }^{235}$.

Ainda que a representação de revistas ou burletas fosse mais lucrativa para os empresários, pouco a pouco as peças do "teatro-sério" ganhavam espaço na cena teatral brasileira.

235 GALANTE, J. Op. cit., p 76. 


\subsubsection{Cláudio de Souza: Flores de Sombra}

Em 22 de dezembro de 1916, inaugurou-se o Teatro Boa Vista com a peça Flores de Sombra, de Cláudio de Sousa, montada pela Companhia de Leopoldo Fróes. Também participavam do elenco Apolônia Pinto, Colás, Amália Capitani, Cecília Neves, Eduardo Pereira, Emídio Campos, Elvira Pinho, Britto e Ema de Souza.

Miroel Silveira afirma que, a partir dessa encenação, o teatro passaria a percorrer nos anos seguintes um novo caminho: o da comédia de costumes de caráter nacionalista ${ }^{236}$. É o início do movimento nacional-regionalista, do qual já tratamos.

Segundo O Pirralho, a crítica considerou Flores de Sombra um dos primeiros trabalhos teatrais brasileiros ${ }^{237}$. Magalhães Júnior, no entanto, considera que partes das virtudes atribuídas à peça pela imprensa, pertenciam mais à representação ${ }^{238}$. Observação semelhante é feita pelo colunista de $O$ Pirralho, o qual declara que o desempenho da Companhia de Fróes, "afinado e correto", muito contribuiu para o êxito da comédia.

A respeito da interpretação dos artistas, o periódico destacou o trabalho de Apolônia Pinto, como a fazendeira "que revive as passadas glórias da distinta artista"; Colás, "que reapareceu no seu antigo esplendor", como o mulato Possidônio; Amália Capitani, como Rosinha, "verdadeira revelação de um temperamento ao qual muito vai dever o nosso teatro"; Emídio Pereira fez um coronel "discreto e sóbrio, sem o desabusado patuá e simiescos esgares com que geralmente atores pouco escrupulosos deformam os tipos de nosso Interior". Ema de Souza, no papel de Cecília, "com sua mocidade flamante deu enorme relevo à fútil e brilhante filha do ministro"239.

Em um cenário dominado por revistas e operetas, a peça foi considerada um primor por não apresentar "uma única frase que possa escandalizar o mais

236 SILVEIRA, Miroel. Op. cit.p. 158.

237 O Pirralho, número 229, 31/12/1916, ano VI.

238 JUNIOR, R. Magalhães. As mil e uma vidas de Leopoldo Fróis. São Paulo. Lisa-Livros Irradiantes S. A., 1917, p.63

239 O Pirralho, artigo cit.. 
pundonoroso ouvido". Além disso, serviu como prova aos críticos de que o desvio de gosto do público era uma justificativa usada pelos empresários gananciosos, que exploravam o "dito chulo" do gênero revista ${ }^{240}$.

Cláudio de Souza, também colaborador da revista $O$ Echo, mereceu artigos elogiosos de seus colegas de imprensa. Eles consideravam a incursão do autor na dramaturgia a abertura para um novo tipo de teatro, sem as velhas fórmulas da revista, com suas "pornografias". A esse propósito escreveu Aldinio Jurema:

A literatura de Cláudio de Souza é suave e consoladora: respeita a amizade, crê no amor, honra a virtude, venera o passado, enobrece, exaltando-os, todos os grandes sentimentos da alma humana. É um contato agradável para o espírito. Essa aspiração para o bem, essa crença na bondade humana, contestada ou incompreendida por tantos escritores, fazem bem à alma, deleitam, agradam e deixam no espírito de quem o lê ou ouve um bem estar, uma doce satisfação, a mesma alegria que nos causa a prática de uma boa ação, a vista de uma bela paisagem, o encontro de um amigo querido, a beleza de um amor verdadeiro; enfim, Cláudio de Souza, pondo-nos em contato com os seus heróis, cheios de elevação e de nobreza, protesta contra o pessimismo que nos amargura inutilmente a vida, abrindo uma janela para o azul e para o sonho. ${ }^{241}$

Alguns críticos mais empolgados consideraram Cláudio de Souza um "espírito genial", comparável a Anatole France:

la dizendo da raridade de um espírito como o de Cláudio de Souza em nossa raça. O espírito de Cláudio é o espírito da raça latina. Nele eu vi muitas vezes, no decorrer da representação da brilhante peça aquela feição de Anatole France, aquela delicadeza, aquela ironia quase imperceptível, aquele modo de tocar nos assuntos sem cansar. Nota-se em Cláudio muito de Anatole. O dom de aflorar a superfície dos temas brilhantemente, ironicamente, não dando senão de vez em vez um mergulho para a

240 O Pirralho, artigo cit.

241 O Echo, número IX, março de 1917, ano XV. 
profundidade de um coração ou de um pensamento, faz de Anatole e de Cláudio dois irmãos. ${ }^{242}$

A boa recepção ao trabalho de Cláudio de Souza acabou servindo como estímulo aos autores nacionais. Nas rodas de café, bares, confeitarias, nos encontros entre intelectuais, o assunto passou a ser as novas peças que se produziam $^{243}$.

O lamento em torno do teatro nacional ainda se fazia presente. Ou o teatro nacional estava em "decadência" ou ele era um mito, pois ainda não existia. A estréia de Flores de Sombra, no entanto, serviu de consolo para os que perpetuavam essa ladainha. Para o colunista de $O$ Echo, quem tentava algo de novo na dramaturgia nacional via-se entregue aos caprichos daqueles que lhes mutilavam as peças, sonhando com o sucesso nos palcos. Escapara de tal desgosto, o Dr. Cláudio de Souza, "emérito e operoso cultor da literatura teatral", "com esse mimo de graça e elegância que é Flores de Sombra". Quanto ao enredo, escreveu o colunista:

Buscou, através de um fio de enredo delicado, estudar a vida, ainda, religiosamente tradicional dos nossos antigos, em luta aberta com a civilização que tudo invade, num plaustro de ouro, derrocando tradições para endeusar as inovações e os luxos do requinte moderno. ${ }^{244}$

O enredo da peça oscila entre o provincianismo da cidade de São Paulo e a sua crescente urbanização. $O$ autor faz um retrato da tradicional família paulista com seus valores apegados a um colonialismo ainda vigente e a metropolização que invade a cidade trazendo as modernidades do século XX.

A montagem dessa peça estava dentro dos moldes do que seria um teatro nacional tão sonhado por autores, críticos e intelectuais. Era uma peça escrita por um brasileiro e encenada por uma companhia brasileira. E mais, não bastavam

242 O Echo, número X, abril de 1917, ano XV. 243 JUNIOR, R. Magalhães. Op. cit., p.65. 
peças escritas por autores nacionais, elas precisariam recriar o ambiente brasileiro, e isso Cláudio de Souza também fez:

Cláudio de Souza dá ao seu teatro esse caráter fundamentalmente brasileiro, fugindo, assim, ao mimetismo da vida elegante da Europa. ${ }^{245}$

Com palavras exuberantes e rebuscadas - típicas dos intelectuais à época-, o Dr. Fogaça de Almeida descreveu as sensações que lhe despertaram as Flores de Sombra:

Elas por vezes tocaram-me tão dentro d'alma, que esta alma derramou algumas gotas do que eu chamarei lágrimas. Benditas "Flores" que me emocionaram até as lágrimas. É verdade, bem o sei, que este meu coração é mais sensível do que os outros, o que atribuo a uma fragilidade congênita. Mas dizer-se de uma obra de arte que ela comove equivale a dizer-se que ela é sincera, natural, bela e traz no conjunto um tal sopro de vida que empolga o espírito ainda o mais bronco. As "Flores de Sombra" não sendo feitas para espíritos broncos têm no entanto o condão mágico de arrebatar pelo menos cincoenta por cento dos que as conheçam...

"Flores de Sombra" encerram um espírito delicado e tão fino que é de estranhar num escritor de nossa raça. $E$ não nos esqueçamos que este escritor, que é a verdadeira Flor de Sombra - flor maravilhosa que bem merecera outro meio - está no meio paulista, isto é, no meio mais estéril que o industrialismo terá algures produzido. ${ }^{246}$

Em março de 1917 já subia à cena outra peça de Cláudio de Souza, $A$ Renúncia, montada pela companhia do português Alexandre Azevedo. O drama foi recebido com direito à festa de gala no teatro Municipal de São Paulo, tendo Alfredo Pujol como orador. No entanto, não fez o mesmo sucesso de sua

245 O Echo, número XI, junho de 1917, ano XV.

246 O Echo, número X, abril de 1917, ano XV. É importante salientar que muitas vezes as citações são longas, mas seria impossível não reproduzir, na íntegra, palavras como as do Dr. Fogaça de Almeida. 
antecessora. A crítica considerou que a atuação dos atores castigou as frases bem elaboradas e os períodos bem construídos do dramaturgo.

$\mathrm{Na}$ opinião de Aldinio Jurema, a Companhia que a representou deixou a desejar. Cremilda de Oliveira teria sido "impecável”, Alexandre Azevedo e Antonio Serra também "souberam dar aos seus papéis o relevo conveniente", mas os outros foram "desastrados":

Aquele português velho e desdentado, a mamar o charuto, dizia coisas que ninguém entendia. A frase de Cláudio de Souza, límpida, sonora, castigada, perdia todo o encanto, tornava-se incompreensível na boca daquele filósofo de fancaria. ${ }^{247}$

Uma das principais críticas dirigidas à encenação de $A$ Renúncia foi o fato de a peça ter sido representada por atores portugueses, pois a prosódia portuguesa não se adaptava nas frases bem feitas do dramaturgo. Se a peça tivesse sido representada por brasileiros, que tivessem um curso teatral, alcançaria ainda maiores aplausos, afirmou Aldinio Jurema. Para o crítico, o primeiro passo para a nacionalização do teatro estava em fazer a nacionalização dos artistas.

Em ocasião da representação de $A$ Renúncia, em Porto Alegre, o Jornal do Comércio publicou uma reportagem sobre a peça ${ }^{248}$. Flores de Sombra ainda não havia sido representada na cidade, mas de seu autor, o público já conhecia a comédia Eu arranjo tudo. Conforme a reportagem, a capacidade de registrar em minúcias os momentos da vida real, de ser um observador perspicaz, Ihe fora atribuída pelos críticos, desde essa primeira peça. O protagonista de Eu arranjo tudo seria um flagrante dos tipos que viviam nas grandes cidades. Essa mesma capacidade de observação aparecera em $A$ Renúncia, principalmente no segundo ato, no qual, por meio de "traços rápidos e incisivos", o meio e as características do jornalismo carioca são expostos.

247 O Echo, número IX, março de 1917, ano XV.

248 Reportagem publicada no Correio do povo, reproduzida pelo Jornal do Comércio, do Rio de Janeiro, e, posteriormente, reproduzida em $O$ Echo, número XI, junho de 1917, ano XV. 
A Renúncia mereceu um artigo de Olavo Bilac na Revista do Brasi ${ }^{49}$. Bilac não adotou o mesmo tom entusiasmado de muitos de seus colegas da imprensa, ao contrário, analisou a peça e apontou falhas em alguns trechos dos diálogos e no perfil psicológico dos personagens. O poeta afirmou que o talento do novo dramaturgo merecia mais do que o "elogio trivial e inexpressivo" que Ihe dedicavam as colunas diárias da imprensa.

São de Bilac as palavras abaixo:

O dramaturgo é autêntico: o Dr. Cláudio de Souza tem, efetivamente, a fibra teatral e sabe tramar e conduzir a ação com muita arte. Os seus defeitos são apenas os defeitos de quem começa: um pouco de hesitação ou, melhor, alguma indecisão no traço psicológico dos personagens e falta de naturalidade em alguns trechos do diálogo.

A fala empolada dos personagens mereceu observações do poeta. Faltava simplicidade no palavreado, o dramaturgo exagerara nas palavras raras e nas imagens líricas dos diálogos, como na fala entre uma menina de pensão e um cronista de jornal. Buscando expressar-se bem, Cláudio de Souza usara termos raros e expressões de uso pouco freqüente, que resultou em personagens artificiais.

Outra falha do autor teria sido alongar demais, em alguns momentos, as falas de amor da protagonista:

Amor que raciocina demasiado, que se demonstra por $a+b$, que se compraz em análises minuciosas e eloqüentes - não é amor profundo, não é amor de coração: é amor de cabeça, é literatura.

A intenção do autor de pintar uma mulher inteligente e carinhosa, capaz de sacrifícios, não se realizou devido à "mania de dissertação" da personagem. Ou seja, esbarrou mais uma vez na questão da linguagem. As frases "tão lindas e recortadinhas", proferidas pela heroína, falseavam seus sentimentos e levavam o 
espectador a sorrir de seu sofrimento. A impressão deixada era de que 0 sofrimento era menor do que parecia, sendo somente um pretexto para "variações literárias":

Em vez de uma amorosa legítima, uma amorosa ao feitio de Mlle. Lespinasse ou de Mariana Alcoforado, a gente suspeita, de quando em quando, que ali está apenas uma amorosa secundária, uma amorosa de palavras, uma Mme. de Stael, mais preocupada com o boleio da frase e o jogo das imagens do que com as pulsações do coração...

Bilac afirmou que outros defeitos ainda poderiam ter sido apontados, uns de certa importância, outros insignificantes. No entanto, todos somados não seriam suficientes para destruir o valor da peça. Alguns nem teriam sido notados, não fosse a interpretação "desastrada" da Companhia de Alexandre Azevedo. Cenas que exigiam naturalidade na inflexão da voz e no desdobrar dos gestos foram "horrivelmente estropiados por uma declamação de melodrama".

Se a medicina não lhe atraía mais, o mesmo não se pode dizer da dramaturgia. Pouco mais de um ano após o estrondoso sucesso de Flores de Sombra, em junho de 1918, Cláudio de Souza via sua nova peça, Outono e Primavera, ser apresentada com êxito, novamente pela companhia de Leopoldo Fróes, desta vez no Trianon. O elenco era formado por Apolônia Pinto, Belmira de Almeida, Átila de Morais, Henrique Machado, Plácido, Cecília Neves, Cordélia Barros, Clara Lopes, Amália Capitani, Eduardo Pereira e Carmen de Azevedo.

Segundo artigo publicado nas páginas de $O$ Echo, já não havia como negar a Cláudio de Souza o título ao qual ele teria direito, o de primeiro comediógrafo brasileiro da atualidade ${ }^{250}$. Em Outono e Primavera revelava-se mais uma vez a sua habilidade de escritor teatral, consciente da habilidade dos artistas para os quais escrevia e capaz de encontrar neles qualidades ainda não aproveitadas. Outra qualidade do autor era saber encaminhar a crítica social, sem chocar as

250 O Echo, número XII, janeiro de 1918, ano XVI. 
pessoas. Assim sendo, mesmo que a crítica atingisse o espectador, dar-lhe-ia a ilusão de que "a agulhada foi feita para ferir, não a ele, mas ao vizinho ao lado".

Se a linguagem utilizada foi alvo de duras críticas por parte de Bilac, para o colunista de O Echo era uma qualidade. O seu diálogo "elevado", a frase "trabalhada" e "brunida", a linguagem "esmaltada" e "brilhante" deliciava o ouvido de quem acompanhava a peça palavra por palavra.

A interpretação dos atores da Companhia de Fróes foi muito elogiada no artigo. Apolônia Pinto e Leopoldo Fróes, os dois principais intérpretes da peça, saíram-se muito bem. Ele foi o Gustavo que deveria ser, segundo as palavras do cronista, e ela apresentou um trabalho inevitavelmente ótimo. Belmira de Almeida confirmou as conquistas anteriores com esse trabalho; Átila de Moraes, como o velho refinador de açúcar, "foi-se, como sempre, muito discretamente". Amália Capitani compôs muito bem o papel da menina Beatriz.

Eduardo Pereira e Carmen de Azevedo foram responsáveis por quase toda a parte cômica da peça. O ator representou um "pardavasco", o Faustino, cujo ideal de vida era ser um chofer. Em comicidade, seu papel excedia o de Possidônio, de Flores de Sombra, por ser mais familiar à platéia. A mulata, representada por Carmen de Azevedo, desde a primeira entrada fez a platéia rir, não sendo necessário para isso exagerar nos dengues e "sestros" exigidos pela personagem.

Em 1921, outra peça de Cláudio de Souza tem espaço na imprensa. Mas desta vez foi o próprio autor quem escreveu um longo artigo no Correio da Manhã, rebatendo as críticas feitas à sua peça Os bonecos articulados ${ }^{251}$. Essa peça fora criticada por apresentar um marido que, ao flagrar a esposa em adultério, resolve a situação por meio de um inusitado arranjo com o amante. O marido, convencido de que os homens só se interessam por mulheres casadas porque elas não dão despesas e não podem cobrar nada, prega uma peça no amante ao oferecer-lhe que este leve a esposa com "armas e bagagens". O artigo, "Verdade e verossimilhança", debate a questão da verossimilhança, da verdade no teatro, pois alguns críticos consideraram esse acontecimento inconcebível na vida real.

251 Revista do Brasil, número 64, abril-junho/1921, ano VI, vol. XVII 
Além das peças tratadas anteriormente, também foram levadas à cena $A$ Jangada ou $A$ vida em Ponte Velha, pela Companhia de Comédias do Teatro Trianon, do Rio, na temporada de fevereiro a março de 1921; Uma tarde de Maio, por Leopoldo Fróes, em agosto de 1921. Em 1923, A escola da mentira é representada pela Companhia Brasileira de Comédia; e, nesse mesmo ano, a Companhia de Oduvaldo Vianna montou Exemplo do Papai.

Em uma época saturada de autores que investiam somente no teatro musicado, Cláudio de Souza aparece, e logo é apontado como o benfeitor do teatro nacional. Ansiava-se por um teatro nos moldes apresentados pelo jovem médico paulista: um "teatro literário", cujo riso era provocado não por ditos chulos e palavras desonrosas, mas por "frases de espírito e bom gosto". Assim se explica o frenesi em torno de sua dramaturgia. 


\subsubsection{Mon Coeur balance e Leur Âme: Guilherme de Almeida e}

\section{Oswald de Andrade}

Causaram polêmica no meio teatral as peças em francês escritas por Oswald de Andrade e Guilherme de Almeida. Desde o início do século a influência estrangeira já era questionada pelos intelectuais.

Em janeiro de 1916, O Pirralho registrou um encontro, ocorrido na redação d' A Cigarra, em que os autores leram a um grupo de intelectuais a peça Mon Coeur balance ${ }^{252}$. O grupo era formado por Gelásio Pimenta, Jacomino Define, Júlio César da Silva, Dr. Antônio de Albuquerque Lins, Dr. Vicente Rao, Paulo Mazzoldi, Joaquim Corrêa, Antônio Pereira Lima, Dr. Alberto Salles, Domingos Define, José Marques Campão, Dr. Edgard R. do Nascimento, Pedro Rodrigues de Almeida, Marco Aurélio de Almeida, Ignácio Ferreira, Dr. Carlos Moraes de Andrade (pai de Mário de Andrade), Dolor Brito Franco e Antonio Define.

A peça causou boa impressão e os escritores foram muito aplaudidos e cumprimentados.

Nesse mesmo número da revista, Dolor de Brito escreveu sobre Mon Coeur balance. $\mathrm{O}$ artigo começou destacando o fato de que $O$ Pirralho se compunha de uma roda literária muito moça: Juó Bananére, Cornélio Pires, Oswald de Andrade e Guilherme de Almeida, esses últimos "duas genuínas individualidades literárias criadas e desenvolvidas pelo Pirralho, brejeiro e traquinas".

A peça teria sido apresentada a Dolor de Brito e Sampaio Freire na noite de Natal, na residência de Oswald de Andrade. O que era só uma brincadeira literária transformou-se em uma peça de valor, escreveu o intelectual. Os autores teriam combinado de escrever uma peça só para os íntimos como um mero entretenimento literário. No entanto, a peça saíra tão boa que Ihes exigiram publicidade, e a sua representação. O Correio Paulistano publicou uma cena da peça, acompanhada de elogios. Segundo Dolor de Brito:

252 O Pirralho, número 210, 08/01/1916, ano VI. 
As obras perfeitas não podem ser assim escritas quase de um jato, entre uma piada e uma frase de espírito, mas os moços de talento às vezes de uma palestra inteligente tiram e concebem obras literárias quase perfeitas. ${ }^{253}$

A peça, ambientada em uma praia do Guarujá, mostra o envolvimento amoroso entre os jovens Marcela e Gustavo. Em um elegante hotel, desfilam estrangeiros ricos e pessoas viajadas a conversar sobre os prazeres da vida moderna, a fazer intrigas e armar situações amorosas. Moça frívola e mimada, Marcela flerta também com o amigo de Gustavo, Luciano, e é por ele correspondida. Ao tomar conhecimento desse triângulo amoroso, e sofrendo com a indecisão da mocinha, Gustavo pede que ela escolha entre Luciano e ele. Diante disso, ela responde que seu coração balança entre os dois rapazes. Sua resposta abala a amizade entre os amigos. Mas, num desfecho semelhante ao de Flores de Sombra, Luciano revela que havia se aproximado de Marcela só para testar a fidelidade dos sentimentos da amada pelo amigo.

Restabelecida a amizade entre eles, Marcela acaba ficando sozinha.

De acordo com o artigo, as cenas são de uma admirável naturalidade e de encantos literários extraordinários. A comédia-drama - assim definida por Dolor de Brito - era moderna, encantadora, leve, cheia de emoção e de vida. Como dramatização da vida real, a peça seria perfeita.

O crítico faz uma observação sobre o fato de a peça ter sido escrita em francês só no final do texto. Comenta que, a esse respeito, uns consideram um defeito, outros acham que, sendo a peça um conjunto de cenas refinadamente elegantes, só poderia ser escrita em francês mesmo.

Aqueles que viram esse fato como defeito seriam os nacionalistas, fascinados pela palavra mágica de Bilac.

Mon Coeur balance rendeu um terceiro artigo na mesma edição de 08/01/1916, de O Pirralho. Nesse caso foi reproduzida a opinião de O Estado sobre a peça. A primeira observação do texto diz respeito à língua em que a peça foi escrita. Conforme o periódico, o leitor, intrigado, poderia se perguntar "Por que em

253 Idem, ibidem. 
francês?", uma vez que os autores, sendo brasileiros, estariam na obrigação de escrever na língua deles e do país. A única resposta plausível, de acordo com o texto, era a de que eles eram moços, quase meninos, e que o "verdor dos anos explicava essa e outras extravagâncias".

A opinião de $O$ Estado é que os atos da peça são breves, movimentados e conferem agilidade ao texto, favorecendo os envolvimentos amorosos, "que começam em flertes ligeiros e acabam em súbitas decepções". Além dessas qualidades, destacam-se a tessitura da comédia, o corte das cenas, a individualidade dos personagens e o diálogo.

A 22 de janeiro de 1916, em resposta às críticas da revista O Queixoso, endereçadas à peça, $O$ Pirralho publicou o artigo "A propósito de Mon coeur balance"254, mesmo nome do texto de O Queixoso. Usando o pseudônimo Delicatus, em oposição a Brutus, pseudônimo do escritor de O Queixoso, o autor do texto, delicadamente, retrucou que a imprensa mais autorizada de São Paulo "transbordou de entusiasmo com a peça" de Oswald de Andrade e Guilherme de Almeida, ou seja, desqualificou a revista concorrente.

O artigo de $O$ Queixoso comentava o seguinte:

A peça, escrita em francês por dois jovens bandeirantes, que aqui nasceram e aqui vivem, provocou, no arraial dos críticos da imprensa diária, arrepios de nacionalismo ofendido e entraram todos a verberar os pobres rapazes que assim ousaram menosprezar o pátrio idioma.

A peça não é má - dizem - mas não achamos justificativa para o fato de adotarem nela um idioma estranho, desprezando o nosso, tão rico, tão maleável e tão belo! ? $^{255}$

A justificativa, no entanto, encontrou-a O Queixoso. Se Oswald de Andrade e Guilherme de Almeida tivessem escrito a peça em português teriam passado inteiramente despercebidos pelo público e pela imprensa, e somente alguns amigos teriam conhecimento de seus esforços. Adotando o francês tiveram quem os ouvisse e a imprensou levou os seus nomes "a todos os recantos da terra".

254 O Pirralho, número 211, 22/01/1916, ano VI.

255 O Queixoso, número 3, 13/01/1916, ano I. 
Continuou o crítico Brutus:

Clamam pelo desprezo às coisas pátrias, numa terra em que o brio nacional anda de rojo pelas sarjetas, em que a etiqueta estrangeira vale 50 por cento mais que a nacional!

Oh! Que bom seria se Deus...fendendo o Brasil, de Norte a Sul, absorvesse estes vinte milhões de vencidos, que no meio de uma natureza exuberante e pródiga, rastejam e se rojam pela lama do cabotinismo...

Irritado com as críticas, O Pirralho retrucou:

Destoando do coro de louvores da imprensa autorizada de São Paulo, [ O Queixoso] deu um berro e querendo desmanchar o perfume do incenso que as caçoilas de autorizados jornalistas espalharam sobre os novos comediógrafos, tentam um arroto de superioridade... ${ }^{256}$

O Pirralho considerou desrespeitosa a atitude d' O Queixoso para com Oswald de Andrade e Guilherme de Almeida, chamados de cabotinos. Assim sendo, redigiu as seguintes palavras:

...resolvemos dizer nestas linhas que achamos supinamente inepta a notícia com ares de crítica com que $O$ Queixoso houve por bem estracinhar os louros de Oswald de Andrade e G. de Andrade e Almeida. ${ }^{257}$

Acrescentou ainda que numa cidade como São Paulo em que a literatura não encontrava terreno fértil, exceto alguns poucos escritores de têmpera, o aparecimento de Mon coeur balance, possuidor de qualidades literárias incontestáveis e de técnica teatral, devia ser registrado pelo $O$ Queixoso com palavras mais inteligentes.

Quanto à peça ter sido escrita em francês, A Vida Moderna considerou o fato sem importância, sem motivo para censuras. Justificou que Machado de Assis, 
na mocidade, também escrevera comédias em francês, para serem representadas por amadores, em teatrinhos particulares. Além disso, fazendo coro à explicação de $O$ Estado, argumentou que os novos dramaturgos seriam moços, e aos moços todas as audácias seriam permitidas ${ }^{258}$.

O artigo de $A$ Vida Moderna apresenta algumas imprecisões a respeito da peça. Seu autor registra que a ação passa-se em Santos, e que a peça não teria precisamente um enredo. A ação, segundo as informações, desenrolava-se num hotel de praia entre pessoas elegantes, durante uma curta estação das águas. $O$ episódio de amor servia para ligar as cenas principais. Afora essas observações, os atos são considerados curtos, e os diálogos com uma vivacidade surpreendente.

Após os pronunciamentos a respeito de Mon couer balance, outra peça dos escritores causou polêmica nas páginas das revistas. Em maio de 1916, O Pirralho reproduziu, novamente, uma reportagem de $O$ Estado com informações sobre duas novas comédias de Oswald e Guilherme de Almeida. Uma em francês, Leur Âme; e outra em português, ainda inacabada, A Escalada ${ }^{259}$.

O teatro, abandonado em um estado de extrema degradação, poderia lucrar com a dedicação de ambos, escreve $O$ Estado. A leitura das peças seria realizada no dia 03 de maio, às 16 horas, na redação do jornal, para um seleto grupo de convidados. Leur Âme já havia sido lida, havia poucos dias, no Rio de Janeiro, na sede da Sociedade Brasileira de Homens de Letras. Mas, ao que parece, recebera críticas por ter sido escrita em francês.

As críticas foram contestadas por O Pirralho, o qual, na defesa dos escritores, afirmou que as duas comédias, por uma extravagância um tanto quanto impatriótica, foram escritas em francês, mas que nem por isso mereciam ser desqualificadas, como fizeram alguns "chauvinistas cariocas"260.

Antonio Define, com uma opinião divergente da de Dolor de Brito, escreveu ser, sem dúvida, lamentável não terem sido as comédias escritas em português. No entanto, era inaceitável hostilizar os teatrólogos por terem preferido o francês

258 A Vida Moderna, número 279, 13/01/1916, ano XI. 
ao português:

Que a crítica assinale e censure a falta de patriotismo dos comediógrafos estreantes, admite-se, mas o que absolutamente não se pode admitir é que ela, empunhando a férula do chauvinismo, esqueça a sua missão e se transforme num ridículo gritador de patrioteiras insulsas. ${ }^{261}$

A crítica, de acordo com Define, podia apontar falhas na estrutura das peças, como dizer que o tipo de Marcela fora apenas esboçado, ou que sua figura não era bastante verossímil, porém não podiam dizer que faltasse movimento nas cenas, ou que faltasse vida, colorido e emoção nos quatros atos em que se desenrola Mon coeur balance.

A cena em que Gustavo descobre que Luciano também ama Marcela é de uma "beleza surpreendente, de uma força emotiva que seduz e subjuga". Em nenhuma outra cena de autor estreante, considera o crítico, a força de sugestão e o poder emocional atingiram tão alto grau, como quando Luciano revela sua verdadeira intenção ao cortejar Marcela.

Antonio Define não titubeia em colocar Mon coeur balance acima de Leur Âme, seja do ponto de vista da técnica teatral, seja do ponto de vista estético e emotivo. Leur Âme, conforme suas palavras, era um estudo anatômico de um coração de mulher, complicada e extravagante. Natália, a protagonista, ama o marido, mas possui um amante. Ambos tentam prender a mulher amada, mas podem ter seu corpo, não sua alma. $\mathrm{Na}$ incerteza sobre com quem ficar, ela os abandona e parte com um caixeiro viajante.

O aprofundamento psicológico que apontaram faltar na figura de Marcela encontrava-se na figura feminina de Leur Âme, prossegue Define. No entanto, essa segunda peça não possuía a força da emoção, a poesia, a vivacidade e o colorido da primeira. Apesar disso, Leur Âme também possuía sua beleza e sentimentos:

Em Leur Âme há também cenas de beleza comovente, como é todo o primeiro

261 Idem, ibidem. 
quadro do segundo ato, em que Natália põe a nu a sua alma complicada, narra as extravagâncias do seu coração, revela os mais íntimos segredos de sua consciência ao amante que a ouve aterrorizado, perplexo, batido, e que vê desmoronar-se de roldão o seu amor, transfigurar-se aquela mulher que ele julgava somente sua, mudarem-se aqueles sentimentos que the pareciam tão diversos, apresentar-se aquela alma polimorfa, complicada, mutável, como era de fato, e não como ele a sonhara e pensava possuí-la. ${ }^{262}$

É possível afirmar que, em 1916, Oswald de Andrade já apresentava uma visão moderna da mulher, com seus desejos, suas dúvidas em relação ao casamento e seu papel de mulher e esposa.

A 16 de dezembro de 1916, a famosa atriz Suzanne Després, acompanhada de Lugné Poe, apresentou no Teatro Municipal o segundo ato de Leur Âme. Os atores, que viajavam em missão cultural pela América do Sul, de propaganda do governo francês, não vieram com o propósito de apresentar um repertório vasto. Fizeram conferências, recitaram poesias, apresentaram cenas de peças, como no caso de Leur Âme. Segundo A Vida Moderna, o espetáculo, em que foi apresentado um ato da peça de Oswald e Guilherme de Almeida, era em honra à memória de Emile Verharen, e em homenagem a alguns escritores brasileiros de expressão francesa ${ }^{263}$.

A atuação dos atores deu relevo e vida à cena de amor do segundo ato, escreveu o crítico. Suzanne Desprès falou de cor o seu papel, enquanto Lugné Poe, apesar de ler a sua parte, a fez com graça e naturalidade, imprimindo à sua personagem grande realismo.

Se essas peças de Oswald de Andrade não anunciam a ferocidade da sua crítica presente em $O$ Rei da Vela, A Morta, O homem e o cavalo, ao menos já revelavam um escritor de inegável qualidade literária.

262 Idem, ibidem.

263 A Vida Moderna, número 302, 28/12/1916, ano XII. 
2.3.3. Importantes representações destacadas nas páginas da imprensa: Eva, de João do Rio; O Contratador de Diamantes, de Afonso Arinos.

Embora algumas peças não tenham merecido a publicidade reservada a Flores de Sombra ou Mon Coeur balance, elas tiveram um papel de destaque no cenário teatral da época, que procurava se delinear e apagar o rótulo de decadente.

É o caso de Eva, de João do Rio. Antes mesmo de sua estréia nos palcos, a imprensa já se ocupava da peça. $O$ Pirralho - comentando a peça em três colunas distintas na edição de 10/07/1915 - anunciou que, apesar de desconhecer o seu enredo, confiava no trabalho dos intérpretes da Companhia Adelina Abranches, responsáveis pela montagem. Na coluna "Pirralho Social", Ruy Blas ${ }^{264}$ destacou que João do Rio já havia se firmado como observador da vida social e da psicologia urbana, desde a representação de $A$ Bela Madame Vargas. Daí viria, portanto, a ansiedade pela representação de $E v a^{265}$.

O Pirralho, de 17/07/1915, traz uma das críticas mais importantes dirigidas à peça. Na coluna "Lanterna Mágica", Oswald de Andrade dedica um extenso artigo à Eva.

Segundo as palavras do futuro modernista, João do Rio nos trouxe uma Eva logo depois do pecado, na plenitude de suas forças, não uma Eva de cabelos brancos, chorosa das conseqüências matrimoniais. Do pecado, essa Eva trazia o conhecimento do bem e do mal, e do paraíso, guardava a virgindade e a beleza.

Oswald inicia o artigo fazendo revelações e comentários sobre o enredo da peça. Conforme escreveu, Eva, atenta às modernidades de seu tempo, faz uma entrada "quase militar". Vestida com botas e buzina invade a cena, tumultuando o ambiente a seu redor. É uma Eva feliz, forte e provocante para o público, que a segue com grande interesse. A seu lado, Adão apresenta-se inutilizado.

Dentre os muitos interessados em Eva, Jorge é o único a lhe devotar um

264 Ruy Blas é o nome de uma peça de Vitor Hugo. 265 O Pirralho, número 195, 10/07/1915, ano IV. 
sentimento sincero. Surpreendida por ele com uma declaração arrebatada de amor, mantém-se quieta e pensativa, preocupada em arranjar qualquer coisa que teste esse amor. O destino intervém nesse momento, pois nessa mesma noite foi roubado um colar de pérolas da condessa Prates. O ambiente se agita. É então que, como diz Oswald, Eva larga o bote que aprendera da serpente, seis mil anos atrás: "- Fui eu que roubei o colar...".

Adão (Jorge), espantado, resiste, quer rir, chorar, mas se entrega. Passa a ser cúmplice agora, e em seguida será mártir, ao chamar a autoridade e se declarar autor do furto, entregando o colar que fora obrigado a esconder. Mas, como o destino é amigo dos poetas, no momento do sacrifício, surge a verdade. $\mathrm{E}$, como recompensa de suas mágoas, Eva se declara, ardente, em voz alta, na presença de todos. Após essa bem elaborada síntese, Oswald prossegue com a seguinte colocação: "Poder-se-ia desejar melhor para teatro nacional em começo? Creio que não...".

Antes de Sábato Magaldi incluir João do Rio entre os autores crepusculares $^{266}$, Oswald de Andrade já o fizera. São dele as seguintes impressões:

Erra por toda a peça um sutil simbolismo. E como simbolismo em comédia haverá melhor do que a bela, a forte, a inteligente intriga que João do Rio inventou? Será difícil. Em Eva há toda a fábula linda de mulher.

Em relação aos intérpretes, Oswald destacou a "soberana atitude com que Aura Abranches jogou o bluff". Detentora de brusca feminilidade, tentadora e vitoriosa a atriz saiu-se bem no papel. Alexandre Azevedo fez "um Adão de fazer corar todos os homens":

Arrebatado, crédulo, cheio da idéia fixa, a sua criação admirável, foi decerto a melhor constatação de superioridade que o público feminino daquela noite teve em vida. $^{267}$

266 MAGALDI, Sábato. Panorama do teatro brasileiro, São Paulo, Difel, 1962. 267 O Pirralho, número 196, 17/07/1915, ano IV. 
A Eva pequenina e roliça do Casino Antártica fez Adão, decaído, ganhar o Paraíso, conclui Oswald de Andrade.

Eudinyr Fraga sugere, em texto introdutório à publicação de Mon Coeur balance e Leur Âme, que, provavelmente, Oswald tenha recebido influências da personagem Eva, na composição de sua indefinida e inconstante Marcela ${ }^{268}$.

Em um fictício diálogo, publicado em $O$ Pirralho, duas pessoas conversam sobre a peça de João do Rio. O primeiro afirma que o cronista lavrou um tento, que para um meio intelectual como o nosso a Eva já é muita coisa. O seu interlocutor discorda e considera Eva uma peça de "ficelle", sem nenhuma verdade, um armazém de truques, incomparáveis às obras-primas de Caillavet, Bataille e Donnay. O primeiro retoma a conversa e diz que o teatro moderno francês, com raríssimas exceções, resume-se a peças mais ou menos bem conduzidas, movimentadas e cheias de truques habilmente engendrados. $E$ prossegue: "Bernstein, como quase todos, deve o seu sucesso aos truques que sabe preparar com maestria. Que é Le Voleur, que tem alguma afinidade com a Eva, senão uma engenhosa habilidade teatral?". Ao final, pergunta a seu colega se ele nega o talento de João do Rio. O outro responde negativamente, mas acha que o cronista estava muito longe dos comediógrafos franceses ${ }^{269}$.

$\mathrm{Na}$ esteira do movimento de resgate de nossa brasilidade, é apresentada, em maio de 1919, a peça O Contratador de Diamantes, de Afonso Arinos. Os espetáculos aconteceram nos dias 12, 14 e 18 de maio, no Teatro Municipal. Realizada pela elite paulistana, a montagem reuniu membros ilustres da sociedade. O Echo profetizou que a encenação marcaria época nos anais do nosso teatro. Cenários luxuosos e figurino requintado realçaram a beleza da obra de Arinos e transformaram a peça em um espetáculo de encher os olhos:

O bailado do primeiro ato - um minuete - foi uma visão de beleza, um ofuscamento de esplendor, uma doce volúpia de encanto...

Pares a esvoaçarem gráceis sobre ricos tapetes; cicio acariciador de sedas raras; acusmas de beijos castos em mãos esfuziadas - um quadro, enfim, de Watteau, o

268 FRAGA, Eudinyr. “As peças em francês”. In: ANDRADE, Oswald \& ALMEIDA, Guilherme de. Mon coeur balance e Leur Âme. Editora Globo, São Paulo, 2003, p. 20.

269 O Pirralho, artigo cit. 
mimoso poeta da tela. ${ }^{270}$

Mereciam mais do que aplausos os patrícios que se dispuseram a montar "essa jóia" de Arinos, mereciam um verdadeiro culto de admiração, registrou o Echo. Para que os leitores bem conhecessem a peça, a revista reproduziu um artigo de Artur Azevedo, publicado em $O$ país, que, segundo consta, viu no trabalho de Arinos uma tentativa para a criação do Teatro Nacional.

Artur Azevedo conhecera $O$ Contratador de Diamantes em uma leitura realizada no Gabinete Português de Leitura, juntamente com alguns acadêmicos, membros do Gabinete, o ministro de Portugal- Camelo Lampreia- e o Marquês de Paranaguá. O próprio Afonso Arinos faria a leitura da peça.

Já eram do conhecimento de Artur Azevedo os dois primeiros atos da peça, e ele receava que os dois últimos, que não haviam ainda sido escritos, desmerecessem o trabalho, uma vez que o protagonista desaparecia no começo do terceiro ato, por ter sido preso. Temia ele que a ação afrouxasse e que Arinos não pudesse sustentar até o fim todo o interesse dramático despertado de início:

Em teatro, a despeito de quanto pregam os apóstolos da dramaturgia moderna, sou um observador exato das velhas convenções e considero a arte de fazer peças uma arte inferior, se quiserem, mas adstrita a regras e preceitos essenciais de que não é possível fugir, a menos que o autor não faça caso do público e se contente do aplauso, nem sempre sincero, de meia dúzia de amigos. ${ }^{271}$

Mas o comediógrafo confiava na habilidade de Afonso Arinos, que se revelara um dramaturgo e a quem, segundo ele, podia-se aplicar o famoso verso do Cid: "aquilo não é um "coup d'essai", mas um "coup de maitre" ". ${ }^{272}$

O terceiro ato, ele o considerou o mais forte, no qual estava "a imprescindível "scene à faire", recomendada por Sarcey:

O protagonista desapareceu, é certo, para só reaparecer no fim, em condições altamente dramáticas; mas o autor atraiu, com admirável engenho, todos os outros personagens para o primeiro plano, e a própria ausência do protagonista torna-se,

270 O Echo, número X, junho de 1919, ano XVIII, pp. 67-69.

271 Idem, ibidem.

272 Idem, ibidem. 
no terceiro ato, um elemento patético. ${ }^{273}$

A trama conta a história de Felisberto Caldeira, o contratador de diamantes, um bravo paulista, que é injustamente preso, a mando do rei, por ter idéias contrárias às do colonizador. Vítima de um plano arquitetado pelo ouvidor e pelo intendente é algemado e levado ao Rio de Janeiro.

É necessário relembrar que os intelectuais de São Paulo preocupavam-se nesse momento em construir uma imagem positiva da cidade. Assim sendo, a montagem de $O$ Contratador de diamantes é propícia à ocasião, pois traz a figura do bandeirante-herói. O ideal de coragem, justiça, bravura e honestidade associava-se ao bandeirante. A história da cidade ligava-se à imagem de um herói, não a de um explorador.

Havia a possibilidade, não concretizada, de que a peça pudesse ser representada pela Companhia do Teatro São José, sob responsabilidade de Eduardo Victorino. Mas o que Artur Azevedo ansiava era que a obra de Arinos pudesse inaugurar o Municipal, do Rio, o que também não aconteceu.

Como a questão da "decadência do Teatro Nacional" sempre voltava à tona, a montagem de $O$ Contratador de Diamantes deu motivo para que se retomasse esse assunto. Dois meses após as apresentações no Municipal, A Vida Moderna comemorou que finalmente se levantara, como conseqüência imediata do movimento nacionalista, o Teatro Nacional. Assim sendo, o sonho artístico de João Caetano e Artur Azevedo ia, aos poucos, se realizando. As revistas de ano deram lugar à arte. Afonso Arinos, "com a sua arte nobre de um patriotismo elevado", ensinara-nos a olhar com mais carinho para o nosso país:

O autor do Contratador de diamantes, num gesto revelador, apontou para a alma brasileira e para o seu cenário rude das florestas. Não são portanto revistas e pochades de licenciosidades de almanaque, mas arte pura de motivos nacionais puros. $^{274}$

Além de Arinos, o periódico citou como representante desse momento Viriato Correia, e a sua nova peça $A$ Juriti. Acrescentou que, como indicava seu

273 Idem, ibidem.

274 A Vida Moderna, 10/07/1919, ano XV. 
"sugestivo nome", a peça era arrancada do fundo do nosso sertão. É o retrato dos costumes da nossa gente passados em nossa terra. Conforme ainda o texto:

A peça passa-se entre terreiros de café e sambas de noite de S. João, entre carros de boi e cantigas do Norte, entre igrejinhas de Vila e arvoredos sae sombra.

Como se vê, a peça é bem nossa, título, personagens e cenários. ${ }^{275}$

Olavo Bilac também deixou sua contribuição ao teatro, não com trabalho exclusivamente de sua autoria, mas com a tradução da peça Le roi s'amuse, de Vitor Hugo. Essa tradução, feita com a colaboração de Aluísio Azevedo, recebeu o nome de Triboulet. Conforme A Vida Moderna, com o decorrer do tempo, o autógrafo da tradução desapareceu, sendo ignorado até por nossos homens de letras. O seu possuidor, o coronel Pedro Freire, residente em Manaus, ciente de que não havia uma cópia da obra, enviou-a a Coelho Neto. A tradução remetida, porém, estava incompleta. Mas Coelho Neto pensava em encontrá-la, completa, no arquivo deixado pela empresa Dias Braga. O diretor da Escola Dramática dizia haver também nesse arquivo uma tradução feita por ele e Bilac, em versos alexandrinos, da cena da alucinação de Lady Macbeth, feita especialmente para ser representada pela atriz Ismênia Matheus ${ }^{276}$.

Voltando um pouco no tempo, a 1916, encontra-se na Revista do Brasil uma nota informando que Antonio Piccarolo extraíra do romance Dom Casmurro, de Machado de Assis, um libreto para o drama musicado pelo maestro João Gomes Junior, que brevemente seria apresentado em um dos nossos teatros ${ }^{277}$. A curiosidade fica por conta de o libreto ser em italiano. Não temos informação da realização desse intento. Mas, em 1919, A Vida Moderna publicou que João Gomes Junior pretendia levar à cena, na próxima temporada lírica, a sua última peça tirada do romance Dom Casmurro. O artigo diz que Dom Casmurro, segundo as opiniões de músicos eminentes, era uma peça digna de ser representada em qualquer palco europeu ou americano. Quer pela sua composição, quer pela sua inspiração e escolha de motivos. Dom Casmurro seria a expressão brilhante da

275 Idem, ibidem.

276 A Vida Moderna, número 363, 24/07/1919, ano XV.

277 Revista do Brasil, número 9, setembro de 1916, ano I, Vol. III, p. 99. 
fase moderna da nossa música nacional.

Ainda se tratando de Machado de Assis, a revista campineira $O$ Monóculo anunciava para breve a representação de Os Deuses de Casaca. A nota certamente era uma brincadeira, pois informava que a peça já havia entrado em ensaios, tomando parte nela os atores Coelho Neto, Goulart de Andrade, Oscar Lopes, Luiz Edmund, Bastos Tigre, etc ${ }^{278}$.

Uma crônica publicada em O Correio Musical Brasileiro reclamava que só não conhecíamos nossos autores nacionais porque faltava arrojo aos empresários de teatro ${ }^{279}$. Esses dramaturgos inéditos mereceriam a consagração para as suas obras, a fim de que não se dissessem que não tínhamos talentos para operar o milagre da criação do teatro brasileiro. O cronista sentia-se no dever de divulgar os nomes desses "heróis desconhecidos", cujas obras, quando em cena, receberiam aplausos de uma platéia culta, sem ser formada por fantoches da moda ou do esnobismo. Os novos dramaturgos seriam representados, na alta comédia e no drama, por Amaral Ornellas, Sérgio Cartieri, Themudo Lessa e Átila Azevedo.

Infelizmente, ou por falta de oportunidade, ou por não apresentarem uma obra capaz de "criar o teatro nacional", como acreditava o cronista, esses "heróis" não marcaram seus nomes nos anais da história do teatro nacional.

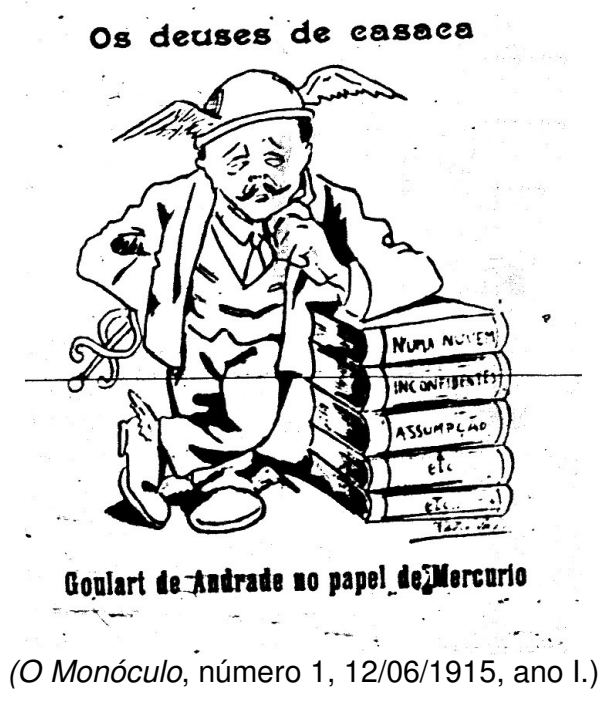

278 O Monóculo, número 1, 12/06/1915, ano I.

279 O Correio Musical Brasileiro, número 4, 7-15 de julho de 1921, ano I, p. $6 .$. 


\section{Capítulo III. Mário de Andrade: um dramaturgo no pré-}

modernismo

Mário de Andrade, além de romancista, estudioso da música e do folclore brasileiro, colaborou ativamente na imprensa da época. Escreveu artigos (ou artiguetes, como se classificavam), crônicas, críticas, publicou poemas e esquetes. Seu nome aparece em periódicos populares, entre eles A Cigarra, Jornal do Comércio, A Gazeta, A Garoa, Miscelânea, Ilustração Brasileira, Papel e Tinta, e O Echo. Esses são apenas alguns dos periódicos em que Mário de Andrade colaborou, pois a lista é bem mais extensa ${ }^{280}$.

E foi nas páginas de $O$ Echo, de 1919, que tivemos a grata surpresa de deparar com um material inédito do autor de Macunaíma. As pesquisas nessas fontes primárias, aliás, podem revelar uma farta documentação ainda não explorada por estudiosos de inúmeras áreas.

Além de essa produção ser importante pelo seu ineditismo e por pertencer a um dos grandes escritores da literatura brasileira, surpreendeu-nos também o fato de ser totalmente relacionado com o objeto de nossa pesquisa. Esse material é composto de seis esquetes de teatro de Virtuosos e Farrapilhas, coletânea de esquetes da qual já se conheciam Primeiro Amor e Eva, texto escolhido pelo autor para figurar entre seus escritos de Primeiro Andar e, posteriormente, em Obra imatura. Aliás, em Primeiro Andar encontram-se outros esquetes, publicados anteriormente em revistas, como Cocoricó e Por trás da porta.

Os esquetes de Virtuosos e Farrapilhas, ou Cenas de fantasia como foram chamadas por seu autor, trazem a assinatura de Mário de Morais Andrade. Somente uma, Teus parentes, é assinada por Eufrazio Pessoa, que julgamos ser um pseudônimo do autor, uma vez observadas as semelhanças entre esse e os outros textos.

Infelizmente, nos falta a primeira "Cena de fantasia" dessa coletânea. Os esquetes encontrados vão do número II ao VII, constando aquele no mês de junho

280 A respeito da atuação de Mário de Andrade na imprensa ler LOPEZ, Telê A. P. Ancona. Mário de Andrade. Cronista na imprensa. Tese de Livre Docência apresentada ao Departamento de Literatura Brasileira, FFLCH/USP, 1991. 
de 1919, e este, em dezembro de 1919. No acervo da Biblioteca Nacional, onde $O$ Echo foi localizado, há uma lacuna na coleção correspondente aos meses de janeiro a maio de 1919. Há a possibilidade, portanto, de que a primeira "Cena" esteja nesses meses da revista, ou em outro periódico, com o qual Mário colaborava $^{281}$.

Segundo Telê Ancona Porto Lopes, Mário lamentou em uma entrevista, em 1942, que seus textos de início de carreira, os quais rejeitara, pudessem ser recuperados em jornais e revistas ${ }^{282}$. Com exceção feita a Primeiro amor, os outros esquetes nem sequer constam do álbum de recortes, que hoje se encontra no Arquivo Mário de Andrade, no IEB-USP, organizado por sua irmã e seu secretário. Não podemos, pois, saber se esses textos foram renegados pelo autor ou simplesmente não foram anexados ao álbum por algum outro motivo.

O Echo define-se como "leitura para velhos, moços e crianças. As senhoras têm nela leitura interessante e instrutiva e os homens de gosto literário ou científico recolherão de suas páginas alguma coisa de substanciosa e útil”283. Como se vê, a revista não tinha o intuito de renovação das letras, mas foi ali que Mário de Andrade deu alguns de seus primeiros passos.

Todos os esquetes apresentam uma constante: rubricas bem elaboradas, reveladoras do caráter das personagens, as quais, muitas vezes, insinuam situações ou adiantam, através de comentários, o desenrolar da ação. Na descrição de cenas e personagens, a linguagem utilizada é marcada por um traço parnasiano e art-noveau. Alfredo Bosi, estudando a literatura brasileira da época, afirma que do fim do século XIX à guerra de 1914-1918, os nossos literatos tinham predileção por um estilo floreal, ornamental, representante nas "letras" de um estilo art-noveau arquitetônico e decorativo, expressão da resistência do artesanato à segunda revolução industrial ${ }^{284}$. Entretanto, já é possível vislumbrar leves traços de uma modernidade e de um anseio de renovações lingüísticas nos esquetes, apesar

\footnotetext{
281 Foram pesquisados outros acervos, como o IEB, AESP, BMA, mas não localizamos O Echo de janeiro a maio de 1919, e tampouco o que seria o esquete número 1 de Virtuosos e Farrapilhas. Também verificamos os álbuns de recortes no arquivo de Mário de Andrade, no IEB. 282 LOPEZ, Telê A. P. Op. cit. p. 82 283 CRUZ, Heloísa Faria. São Paulo em Revistas: catálogo de publicações da imprensa cultural e de variedade paulistana-1870/1930. São Paulo: Arquivo do Estado, 1997, p. 105. 284 BOSI, Alfredo. História concisa da Literatura Brasileira. São Paulo: Editora Cultrix, 1994, pp. 196-197.
} 
de o projeto de uma língua brasileira só vir a despontar mais tarde em Mário de Andrade.

A utilização da música como um elemento estruturador da narrativa ainda não se faz presente nesse momento ${ }^{285}$. Em Cravos de Outubro, a referência musical funciona apenas como pano de fundo para efeito de valorização do sentimento das personagens.

O primeiro esquete por nós encontrado é, na verdade, o segundo da coletânea, como dito anteriormente. Publicado em $O$ Echo, na edição de junho de 1919, Viúva Alegre é um texto simples e despretensioso. Aliás, esse é o título de uma das operetas mais encenadas na época. A ação se passa em um baile em casa de ricos, como descreve o autor, no bairro da Liberdade. As personagens, identificadas como "Ela" e "Ele", estão ambientadas neste local.

Antonio Dimas, em seu livro Espaço e Romance, aborda a diferença entre espaço e ambientação. O primeiro seria a simples representação dos elementos da realidade, enquanto o segundo, é representativo de uma maior complexidade, pois exerce uma função dentro da narrativa. Conforme Dimas, "o espaço é denotado; a ambientação é conotada"286. Ou seja, o ambiente reforça traços da narrativa, estando intimamente relacionado à história, não sendo um elemento casual.

Analisando o conto O Queijo, do escritor, Telê Ancona Lopez nota que Mário já fazia tentativas de avançar na imaginação quanto à caracterização do espaço ${ }^{287}$. Dessa forma, considerando o que dizem os dois críticos, acreditamos ser importante nos determos na ambientação retratada nos esquetes. Em Viúva Alegre encontra-se a seguinte representação:

Fim de baile em casa de ricos, na Liberdade. O ouro das luzes está vagamente cansado. Há uma poeira dourada, subtilíssima, recobrindo tudo duma auréola de decadência. Dança-se o maxixe. Ela junto a uma porta, machucando nervosamente o reposteiro entre os dedinhos carminados, conversa com duas moçoilas. Estas,

285 A esse respeito ler LOPEZ, Telê Ancona. Op. cit. p. 80. 
porém, ao convite de dois rapazes, que se chegam, partem enlaçadas, ao ritmo lúbrico.

Mário de Andrade faz uso de um vocabulário parnasiano, o qual corrobora com o ambiente lúgubre da cena, realçando o penumbrismo, a lascividade que paira no ar. A ênfase na locução de ricos (grifo nosso), relacionada à palavra casa, sugere uma crítica ao modo de vida burguês. Dança-se o maxixe, não outra dança qualquer, mas sim uma marcada pela sensualidade, pela aproximação dos corpos.

A personagem "Ela", descrita como "Linda e moça. Moça e linda em excesso", aguarda ansiosamente que alguém a convide para dançar. Sua ansiedade revela-se nos gestos nervosos com os quais "machuca" o reposteiro entre os dedos, enquanto conversa com duas moças. Essas, porém, convidadas por dois rapazes, partem "enlaçadas, ao ritmo lúbrico". Nova menção à sexualidade, à luxúria.

A figura masculina, chamada de "Ele", contrasta com a feminina. "Ele", tido como grande e reservado, alguém que jamais diz o que sente, opõe- se ao comportamento voluntarioso de "Ela".

A ação tem início quando "Ela" convida "Ele" para dançar. Enquanto bailam, "Ela" puxa conversa e confessa que está ansiosa por tirar o luto, e não vê a hora de calçar seus primeiros sapatos brancos. No entanto, não deixa de frisar que isso não era motivo para pensarem que ela não gostasse do marido. Acrescenta que viver de luto era bom para as viúvas velhas, mas... com vinte e dois anos! Durante toda a música, a conversa continua, "Ela" prossegue comentando como é triste ser viúva, pois não se pode nem conversar com um rapaz, sem ser alvo de comentários maldosos. "Ele", todavia, restringe-se a breves comentários e exclamações.

Terminada a dança. "Ela" o convida para sentarem-se em uma saleta, longe do barulho. A rubrica a seguir indica que nesse local há muita luz, alcatifas, jarras, flores fanadas, coxins deliciosos, e um silêncio propício. As flores fanadas, ou seja, murchas, dão o tom de decadência, e o silêncio mostra-se propício à ocasião.

O uso relativamente freqüente de reticências - característico do autor corrobora com o clima de sedução imposto pela viúva, que se insinua para o rapaz: 
Ele - É preciso tanto cuidado para casar, hoje...

Ela - Não. A gente sabendo escolher; os dois gênios combinando... Eu - quer que lhe diga a verdade? - não casei a primeira vez por amor...

Ele - Ah...

Ela - Papai e mamãe é que insistiram muito comigo para que casasse. Era muito bom partido. Rapaz já de trinta anos - eu detesto esses mocinhos bonitos de agora muito rico, bela posição...

(...)

Ela - Eu quero um rapaz que não seja muito moço. Já lhe disse que não gosto desses meninotes de cinturinha. Um rapaz de seus trinta anos, forte, sério, que não use unhas polidas...

Ele - Não gosta de unhas polidas!...

Ela - O senhor usa? Deixe ver...Ah! não usa. Eu logo vi. Que lindas unhas o senhor tem! (Pega- Ihe a mão) Assim é que eu digo: mãos fortes, morenas, sem unhas pontuadas como a das mulheres...Que pulso forte o senhor tem! (Pega-lhe o pulso) Faz muito esporte?

Essa última fala da personagem é carregada de sensações eróticas, reveladoras de seu interesse sexual. "Ela" pega-lhe as mãos, examina-as, sobe para o pulso, o qual pega também, a fim de sentir o vigor da masculinidade de "Ele". Nota-se que o verbo usado por Mário é "pegar" e não "tocar", pois "pegar" é dotado de uma carga semântica mais forte e violenta, o qual não comporta a suavidade de "tocar". As mãos fortes com unhas pontuadas são os símbolos da virilidade desse homem, que não resistirá à investida dessa mulher. A força bruta do homem contrasta com a força da personalidade da mulher.

Podemos sugerir que os personagens despersonalizados, tratados simplesmente por "Ele" e "Ela", sejam representativos de uma esfera mais ampla, a dos homens e das mulheres. Ou seja, os traços comportamentais aqui desenhados são característicos de ambos.

Seria incoerente ao comportamento masculino, se "Ele" não sucumbisse ao jogo de "Ela". Desse modo, ao final da história "Ele" resolve juntar-se à "Ela" em férias no Rio de Janeiro. 
O terceiro esquete de Virtuosos e Farrapilhas, Paulo e Virginia, apresenta um texto mais elaborado, rico na descrição dos personagens, considerando seus aspectos físicos e psicológicos. Assim sendo, ousamos afirmar que nesses esquetes há a presença de um narrador onisciente, ou seja, narrando "por detrás" (Pouillon), adotando um ponto de vista com o qual tudo sabe e tudo vê. Normalmente não se fala em narrador quando se trata de textos teatrais, mas nesses esquetes as rubricas não se limitam a traduzir gestos das personagens, emoções e indicar lugares, as indicações vão além, são mais detalhadas. É como se fôssemos, portanto, guiados pela voz de um narrador, alguém que comenta as cenas e reflete sobre elas, possui autonomia, e se distancia para poder aproximarse dos personagens.

Jean Pouillon, analisando os diferentes pontos de vista adotados pelo narrador no romance, destaca a visão em que o narrador situa-se "por detrás", e afirma que, nessa posição, o narrador encontra-se, por um lado, distanciado do personagem, e, por outro lado, é desse distanciamento que se tem a compreensão imediata dos motivos mais íntimos que o fazem agir ${ }^{288}$. Nas palavras de Lígia Chiappini, esse narrador tem a liberdade de narrar à vontade, e seu traço característico é a intrusão, isto é, seus comentários sobre a vida, os costumes, os caracteres, a moral, que podem ou não estar entrosados com a história narrada ${ }^{289}$.

A história de Paulo e Virgínia se passa em um colégio de meninas de alta sociedade, no Pacaembu. Virgínia, uma linda moça de 16 anos, é enviada por seu pai a um colégio interno. O enredo desenvolve-se com a chegada de Paulo ao local para visitar sua irmã. De fato, Paulo anuncia-se como irmão de Virginia, e a dúvida quanto à verdadeira relação entre os dois é o conflito a ser resolvido.

Nesse esquete, sem dúvida, há intertextualidade com o romance Paulo e Virginia, de Bernardin de Saint Pierre, o qual narra a história de um amor inocente entre os adolescentes protagonistas. No romance, os jovens crescem e são criados juntos na ilha Maurício, uma terra exótica e de beleza pujante. Compartilhando o dia-a-dia e todas as fases de suas vidas, tratam-se por irmãos. Com o passar do

288 POUILLON, Jean. O Tempo no Romance. São Paulo: Editora Cultrix, 1964, p. 62-64.

289 LEITE, Lígia Chiappini Moraes. O foco narrativo (ou A polêmica em torno da ilusão). São Paulo: Ática, 1985, p. 25-70.5. 
tempo, percebem que o que sentem um pelo outro vai além da amizade ou de um sentimento fraterno. Descobrem-se, pois, apaixonados, não uma paixão mundana, fruto de uma sociedade artificial, mas uma paixão pura, livre de vícios e convenções. Daí suspeitarmos de antemão que Paulo do esquete de Mário não é na realidade irmão de Virginia, a não ser que estejamos diante de uma relação incestuosa.

O recurso utilizado na apresentação de Virginia é igual ao da personagem "Ela". O escritor, nesses casos, lançou mão da inversão dos adjetivos para realçar as características de ambas. Ela: "Linda e moça. Moça e linda em excesso". Virginia: "Linda como os amores. Pequena e delicada. Delicada e franzina" (grifo nosso). Em "linda como os amores", criou uma imagem associada às sensações. Esse esquete traz também um Mário mais atrevido quanto ao emprego da língua falada. Enquanto em Viúva Alegre a linguagem é marcada pelos superlativos, em Paulo e Virginia já se encontram expressões como "meia" em "Naturalmente meia escura e friorenta", referindo-se à ante-sala da escola; a junção da preposição de com o pronome ele em "Dar-se-há o caso dele não ser irmão de Virginia!"; e a inobservância à regência verbal, como "Cristo continua de abençoar" em lugar de "continua a"; entre outras. Além disso, há o uso do substantivo com função de adjetivo, lição aprendida com os futuristas. Após repreender Virginia, Mamère, "açúcar outra vez", torna a conversar com a menina. A expressão "açúcar outra vez", indica que a conversa volta a transcorrer em um tom doce e calmo.

O desejo de inovação de Mário de Andrade evidencia-se na personificação da personagem nomeada como "A Porta", cujas características apontam um ser híbrido, meio humano, meio objeto. "A Porta - Solteirona e, apesar disso, discreta. Muda testemunha de despedidas e de lágrimas levianas. Envernizada, silenciosa; e, como todas as tias, inocente e virginal." (grifo nosso). A Porta acompanha a ação das personagens e se revela a mais perspicaz, pois é ela quem nota as verdadeiras intenções de todos e é responsável pela dissolução do conflito. Seus "comentários" dialogam com o leitor, chamando-lhe a atenção para os detalhes da cena, auxiliando e contribuindo com o narrador. 
Assim como em Há uma gota de sangue em cada poema, em que o poeta inovou ao usar a onomatopéia no verso "e o vento com seu oou...", nesse esquete o autor construiu um diálogo em que Paulo conversa com uma irmã, cuja fala se limita a um simples " $z$ z z z z z z", sem que isso cause estranhamento, ou seja, um obstáculo para o pleno entendimento entre os personagens. A tímida aparição desse recurso revela-nos um anseio de rebelar-se contra os moldes parnasianos e de inovação lingüística presente no futuro escritor de Macunaíma.

A ação começa com o som da campainha quebrando o silêncio do ambiente. A Porta já se manifesta: “Quem será?”. É Paulo, chegando para visitar Virginia. O rapaz conversa com Mamère (nota-se que Mário criou um único substantivo com a junção do pronome possessivo "ma" e o substantivo "mère"), a madre superiora, sobre a possibilidade de visitar a moça, e, diante da incerteza da irmã, comenta "Oh! Mamère, eu gosto tanto da minha deliciosa Virginia!" (grifo nosso). Esse arroubo de linguagem, logo no começo da cena, fornece-nos uma pista sobre a verdadeira relação entre ambos. Na seqüência, quando os supostos irmãos encontram-se, Paulo a atrai para os seus braços e, numa longa carícia, trocam um beijo para lá de ardente, ou melhor, nas palavras do autor, um beijo "Fox-Film". Segunda dica endereçada ao leitor sobre a ligação entre os personagens. A Porta, que tudo vê, presencia esse rompante de sentimento dos jovens, e percebe-lhes o entusiasmo. No momento da despedida, o narrador informa que Paulo dá um beijo fraternal em Virginia, que não se contém. Mamère não repara nesse gesto, mas a Porta vê, vê e reprova.

A referência à indústria holywoodiana Fox-Film, na caracterização do beijo, indica a crescente influência do cinema na sociedade, e, além disso, revela uma faceta de Mário explorada futuramente em Amar, verbo intransitivo. Telê Ancona Lopez afirma no prefácio do idílio que a estrutura do texto é construída por "cenas que fixam diretamente momentos", e a narrativa é dividida em flagrantes, isto é, semelhantes às cenas teatrais ou cinematográficas. Em Amar, no primeiro beijo entre Carlos e Elza, o menino se pergunta: "Que gosto que teriam esses beijos do cinema?". Desse modo, podemos afirmar que a idéia da cena cinematográfica já 
estava em Mário, antes mesmo de Amar, verbo intransitivo. O narrar cinematográfico, como denomina Telê, já vinha sendo pensado então desde 1919.

No segundo ato, Mamère expressa a desconfiança de que os jovens não são irmãos, mas o pai da menina, o Dr., confirma a autenticidade do fato. Todavia, fica muito surpreso por saber das visitas de Paulo ao colégio, e proíbe Mamère que elas se repitam, dizendo que o irmão não exerce uma boa influência sobre Virginia por ser ateu. Na cena final, enquanto Virginia conversa a sós com o pai, a Porta, como uma consciência da madre, como aquele diabinho que tenta, que influencia as nossas ações, sugere que algo de estranho pode estar acontecendo dentro do vestíbulo onde pai e filha se encontram.

Je suis la Porte. II y a en moi une admirable serrure, et dans ma serrure un delicieux petit trou. Tu es la superieure. Tu as le droit de savoir tout ce que se passe dans tout collège! Regarde!

De início, Mamère hesita, mas aceita as justificativas da Porta, ela tem o direito de saber o que está acontecendo, e resolve olhar. Mamère flagra o Dr. e Virginia em uma cena suspeita, na qual o pai "tapa a boca da filha contra o peito e Ihe dá ásperos cocorotes". Envergonhado por ter sido flagrado em constrangedora cena, o pai sai envergonhadíssimo e Virginia, "em prantos", abraça-se à madre, fazendo a revelação final:

Mamère - Virginie, repond-moi, franchement. Je ne te ferai aucun mal...(hesita) C'etait bien ton frère, ce garçon?...

Virginia (em prantos) - Oui, Mamère, oui.

Um dado importante a destacar está no final da Cena I, quando Paulo é chamado de Carlos. Questionamo-nos até que ponto foi uma distração do escritor, ou um erro de impressão da revista, pois, nesse caso, a coincidência seria tamanha. Podemos sugerir, mesmo correndo o risco de uma imprecisão, que o nome "Carlos" já acompanhava Mário de Andrade desde os seus primeiros escritos. Afinal, esse não é um nome aleatório na obra do escritor, mas o nome de 
um apaixonado, um rapaz que vive um amor, assim como o Carlos de Amar, Verbo intransitivo, guardadas as devidas diferenças. Aliás, o diálogo com o romance de Bernandin de Saint Pierre faz-se presente também no idílio de Mário. É possível, portanto, que em 1919 Mário já esboçasse uma idéia sobre seu futuro romance, ou idílio amoroso, como o chamou, inspirado pelo romance de Saint Pierre. A temática do amor terno presente no romance francês será levada para o esquete Paulo e Virginia e futuramente para a personagem Fräulein de Amar, verbo intransitivo.

Esse esquete aparenta ser o mais complexo da coletânea Virtuosos e Farrapilhas. Além das inovações lingüísticas, da intertextualidade, do diálogo com as tendências modernas - como o cinema -, confirma o perfil de observador da sociedade atual, de leitor atento e de lingüista de Mário de Andrade.

É característica da época a crítica à influência estrangeira, como já vimos anteriormente, sobretudo a francesa, e nesse esquete o escritor ainda encontra espaço para criticar o francesismo que tomava conta do nosso teatro no período. Já no começo da trama, o narrador explica a nós, leitores, que todas as cenas são faladas em francês e que tomou a liberdade de "as transladar para o vernáculo" a fim de nos poupar do "deplorável calão das personagens brasileiras do fato".

A religiosidade, muito cara ao autor, seguidor dos preceitos católicos, aparece no esquete representada por uma grande imagem do Coração de Jesus, localizada próximo à porta de entrada do colégio. Essa imagem, símbolo do próprio Jesus Cristo, abençoa o ambiente e é cúmplice da ação, parecendo aprovar ou não os acontecimentos. Na primeira visita de Paulo ao colégio, quando ele se apresenta como irmão de Virgínia, a irmã o deixa sozinho por um momento na ante-sala, e o narrador comenta: "Paulo, só, passeia o olhar desocupado; ao encontrar os olhos do Cristo desvia os seus... Irreverente!". Ele repara no comportamento do rapaz, o qual revela a sua falta de respeito para com os elementos sacros. A esse gesto de Paulo, a Porta suspira: "Xi!", em tom de reprovação.

José Maria Barbosa Gomes, em seu estudo Mário de Andrade e a revolução da linguagem brasileira, destaca a presença redundante de partículas negativas 
em Macunaíma, e ressalta que essa é uma tendência bem ao gosto popular ${ }^{290}$. Formulações como "não...mais, "não...nada, "não...nenhuma”, também aparecem em Paulo e Virginia:

"É de supor-se que a porteira tenha dito qualquer coisa; mas fora da cena não se ouviu nada".

"Como! Não há no colégio nenhuma Virginia!".

"Até já me disseram que eu não tinha mais idade de entrar num colégio".

"Eu já Ihe tinha dito que ela não estava mais em idade de entrar num colégio".

Há outros exemplos, mas não é necessário citá-los para nos darmos conta do interesse, ainda não totalmente manifesto, de Mário pela linguagem popular.

Apesar de certas ousadias, a linguagem ainda é marcada, predominantemente, pelo traço parnasiano e art-noveau, caracterizado pela grandiosidade do vocabulário.

Em Cravos de Outubro, o quinto esquete da série, encontra-se um personagem de nome Carlos, um rapaz apaixonado e leviano, como nos informa a sua descrição. O enredo gira em torno do triângulo amoroso formado por Alice, Carlos e Margarida. Alice é uma mulher casada, apaixonada por Carlos, e por ele correspondida. Margarida, irmã de Alice, também nutre o mesmo sentimento pelo rapaz. O texto começa com forma teatral, mas, com o desenvolvimento da história, o narrador assume a voz principal e transforma-o em uma narrativa, relatando as angústias de Alice.

Alice, mulher forte e determinada, aparentemente mantinha um relacionamento com Carlos. A cena inicial mostra um desentendimento entre ambos. Carlos cobra mais atenção de Alice, mas ela insiste que o que havia entre eles era só amizade. Consciente de que seu amor não pode ter futuro, ela o obriga a casar com Margarida.

As renovações lingüísticas aparecem na junção da preposição "de" com o pronome "ele", exercendo função de sujeito, em "Que culpa tenho eu dele ter

290 GOMES, José Maria Barbosa. Mário de Andrade e a revolução da linguagem: a gramatiquinha da fala brasileira. João Pessoa, Editora Universitária/UFPb, 1979, p. 185. 
ouvido?" (grifo nosso). Outra notação lingüística ocorre na frase "A Lua começa de nascer entre as casas" (grifo nosso), com a preposição "de", em vez de "a", regendo o verbo "começar".

A irmã da protagonista é uma jovem faceira e bela. Caracterizada como "a moralidade", esbanja, no entanto, uma sensualidade no modo de falar e agir. O vocabulário empregado pelo narrador realça o clima sexual do texto: "Pende-Ihe do braço esquerdo, unido ao seio, um ramalhete de cravos amarelos" (grifo nosso). A utilização da palavra seio e não peito confirma a ousadia e o desejo do autor de afrontar os padrões estabelecidos. Essa carga sensual continuará na cena em que Alice diz a Carlos e Margarida que eles devem se amar: "Vocês devem amar-se. Vocês se amam". A afirmação de que eles se amam faz a expressão "Vocês devem amar-se" ambígua, uma vez que não nos remete ao sentimento e sim à ação propriamente dita. No momento em que Alice força um beijo entre os noivos, paira na cena uma sensualidade misturada com uma dose de crueldade, uma crueldade irradiada do sofrimento de Alice. Após o beijo, Alice enfatiza: "Agora amem-se", remetendo-nos mais uma vez ao ato sexual.

Ao final da trama, a música acompanha o clima de paixão e sensualidade da cena. Carlos enlaça o corpo de Margarida, e ficam, os dois, envoltos no odor dos cravos. A música, uma valsa vulgar, oferece um ambiente ideal para os apaixonados. Conforme o narrador, não é o tocador que dá expressão à música, mas a Lua que se encarrega do concerto trágico, ao som de um piano que geme, e executa o concerto em meio da tragédia.

A intertextualidade também é empregada nesse esquete, agora com 0 poema Via Láctea de Olavo Bilac. Na cena II, Margarida chega à casa de Alice, e encontra Carlos. Ela traz cravos, presente do Dr. Durval. Questionada sobre como os havia recebido, ela explica que vira o Dr. passar no bonde com os cravos e comentou com as Camargos: "Que lindos cravos! Se ele se lembrasse de me dar um!" Neste momento, o Dr. Durval desce do bonde e a presenteia com as flores. Alice a repreende por tal indiscrição, e ela responde: "Que culpa eu tenho dele ter ouvido?" Carlos completa a fala de Margarida dizendo: "capaz de ouvir e entender estrelas". 
"Ora (direis) ouvir estrelas! Certo

Perdeste o senso!" E eu vos direi, no entanto,

Que, para ouvi-las, muitas vezes desperto

E abro as janelas, pálido de espanto...

E conversamos toda a noite, enquanto

A Via Láctea, como um pálio aberto,

Cintila. E, ao vir do sol, saudoso e em pranto,

Inda as procuro pelo céu deserto.

Direis agora: "Tresloucado amigo!

Que conversas com elas? Que sentido

Tem o que dizem, quando estão contigo?"

E eu vos direi: "Amai para entendê-las!

Pois só quem ama pode ter ouvido

Capaz de ouvir e de entender estrelas."291

Conforme Bosi, Olavo Bilac, nos trinta e cinco sonetos de Via Láctea, encontra o seu motivo mais caro, o amor sensual ${ }^{292}$. Motivo esse semelhante ao de Cravos de outubro.

Margarida e Carlos, decididos finalmente a viverem esse amor, vêem-se a sós, no momento em que a lua começa a nascer, ou seja, na transição do dia para a noite, no crepúsculo. Enquanto os amantes observam o céu, e o piano geme, plangendo, Alice sofre, sozinha, atrás de uma porta escondida num reposteiro de veludo.

O reposteiro agita-se. É Alice. No seu rosto rasgou-se a ruga da desesperança.

Ela antevê o amar que felizes; e, num soluço, amparando-se à porta para não cair, morde o veludo... para não gritar. (sic)

291 BILAC, Olavo. Antologia Poética. Rio de Janeiro: Francisco Alves, 1913.

292 BOSI, Alfredo. Op. cit. p. 228. 
O esquete revela-nos outras leituras permeando sua escrita. Menos explícito é o diálogo com o poema O Crepúsculo da Beleza, de Bilac, na passagem anterior. Mas o mote de ambos também se aproxima.

Vê-se no espelho; e vê, pela janela,

A dolorosa angústia vespertina:

Pálido, morre o sol...Mas ai! Termina

Outra tarde mais triste, dentro dela;

Outra queda mais funda the revela

O aço feroz, e o horror de outra ruína:

Rouba-lhe a idade, pérfida e assassina,

Mais do que a vida, o orgulho de ser bela!

Fios de prata...Rugas...O desgosto

Enche-a de sombras, como a sufocá-la

Numa noite que aí vem...E no seu rosto

Uma lágrima trêmula resvala,

Trêmula, a cintilar, - como, ao sol-posto,

Uma primeira estrela em céu de opala... ${ }^{293}$

Assim como Alice, o eu-lírico do poema sofre e chora por algo que lhe angustia, ao mesmo tempo em que o sol morre e nasce a noite. O "horror de outra ruína" rouba-Ihe a idade(...) "Fios de prata...Rugas", e no rosto de Alice rasga-se a ruga da desesperança.

No poema Resposta nas sombras vislumbramos outro momento de intertextualidade:

"Sofro...Vejo envasado em desepero e lama

todo o antigo fulgor, que tive na alma boa;

abandona-me a glória; a ambição me atraiçoa;

293 BILAC, Olavo, Op. cit. p. 66. 
que fazer, para ser como os felizes?"

-Ama!

"Amei...Mas tive a cruz, os cravos, a coroa

de espinhos, e o desdém que humilha, e o dó que infama;

calcinou-me a irrisão na destruidora chama;

padeço! Que fazer, para ser bom?"

-Perdoa! $!^{294}$

Em Cravos de Outubro, Mário de Andrade, pode-se dizer, bebeu na fonte de Bilac. O concerto final que "embala" a tragédia da protagonista alude, provavelmente, ao último soneto de Tarde, "Sinfonia".

Hoje meu coração, num scherzo de ânsias, arde

Em flautas e oboés, na inquietação da tarde,

E entre esperanças foge e entre saudades erra... ${ }^{295}$

A respeito de Bilac, Bosi registra a sua permanente busca pela obsessão do efeito, que deve manter a impressão desejada até o final grandioso.

Aliás, a obsessão do efeito (sempre relativo ao sistema de valores estéticos do tempo) leva o poeta pela mão através de toda a obra posterior e vai marcar os seus pontos altos mas também os seus limites. Bilac supre a carência de uma real fantasia artística e de um sentimento fundo da condição humana com o intenso brilho descritivo, que conserva graças a um jogo hábil de sensações e impressões. ${ }^{296}$

Esse jogo de sensações e impressões está presente na história do triângulo amoroso, assim como aparecerá em Brincos de juventude.

Cravos de outubro é de grande interesse por trazer o primeiro Carlos da produção marioandradiana. O mesmo podemos afirmar do esquete seguinte,

294 Op. cit. p. 67

295 BOSI, Alfredo. Op. cit. p. 229.

296 BOSI,Alfredo. Op. cit. p 228. 
Brincos de juventude, pois, segundo Telê Ancona Lopez, em conversa informal, o protagonista da ação, Pedrinho, apresenta-se como um embrião do que será o Carlos de Amar, verbo intransitivo.

Em Brincos de Juventude a sensualidade domina toda a ação. Graças à estruturação dos diálogos e à ambigüidade das intenções, a cena nos transporta a um jogo erótico entre Mariana, Josefina e Pedrinho. Elas posicionam-se como bacantes: "As meninas olham fixamente o ar grosso, avivando os lábios, tomando posturas de bacantes", tal como o predador enreda suas vítimas; ele, sem o perceber, é o objeto do desejo, a presa. À imaturidade do garoto soma-se uma virilidade latente, ressaltada na sua descrição:

A mãe teima em conservar-Ihe as calças curtas, apesar do tamanho: mostra, por isso, um par de pernas felpudas, dum moreno pálido.

Mariana, a mais velha, em oposição a Capitu com seus olhos de ressaca, possui "olhos de água parada onde há sombras misteriosas das insônias". Seu olhar pode não atrair como a da protagonista de Machado de Assis, mas é cheio de mistérios, aproxima-se a um lago de águas calmas na superfície, mas revoltas no interior. As sombras misteriosas de seu olhar são provenientes das noites sem dormir, cujos motivos não são revelados, mas sugeridos, no desenrolar do enredo.

A cena se passa em um verão de 1905. A descrição do ambiente é marcada pela linguagem parnasiana:

A rua é escuríssima, como geralmente o eram as ruas de S. Paulo, nessa época. Os revérberos estão longe; e ainda as magnólias interceptam o pouco de luz que deles poderia vir (...) As árvores adustas vibram num perfume humano.

A imagem do Brasil associada à sensualidade destaca o erótico da situação:

A noite é brasileira, sensual: sente-se sobre os ombros como um peso de corpos que ardem no ar. 
Há ainda outro personagem, Fernando, irmão de Pedrinho. Como a descrição antecipa, é um personagem nulo, quase não aparece na história. Mas sua pequena participação é fundamental, pois é a partir do desentendimento entre os irmãos que se toca no assunto "namoro". O narrador julga o personagem na apresentação, censura a si mesmo, e com esse último gesto integra-se à ação, quase se corporificando:

Fernando - 21 anos. Irmão de Pedrinho. Nulo; mas sem ele seria quase impossível reconstruir a cena que... Cala-te boca!"

Fernando, o irmão mais velho, é rejeitado pelas garotas.

Enquanto as meninas insinuam-se para Pedrinho, o menino persegue uma mariposa. A simbologia não podia ser mais clara. A mariposa, semelhante à borboleta, é expressão da metamorfose, da mutação da fase inicial para a adulta. Mariposa, em linguagem regional carioca, remete à prostituta, ou seja, outro símbolo sexual. Estaria Mário de Andrade já dando os primeiros passos na utilização da linguagem regional?

As meninas disputam a atenção de Pedrinho, ao mesmo tempo em que ele tenta pegar a mariposa. Elas o perseguem, e ele persegue a mariposa, a qual em mil esquivanças, recua e aproxima-se. Pressionado para escolher entre Mariana e Josefina, Pedrinho, em um gesto violento, apanha o inseto. No entanto, a passagem para a fase adulta não é concluída, pois Josefina, "passando um dos braços pelos ombros de Pedrinho", segura-Ihe as mãos e o faz largar a mariposa. $\mathrm{O}$ inseto, de asas partidas, tomba na calçada. Pedrinho, desconsolado, pergunta por que não o deixaram apanhá-lo. Josefina diz que é muito feio pegar um bicho tão nojento. Fica a sugestão, portanto, de que o elemento atrativo é justamente a inocência.

Mas o menino, ao ir embora, anda de um lado para o outro, à procura de alguma mariposa no ar.

O esquete seguinte, Primeiro amor, conta agora a desilusão amorosa do jovem Carlito, um rapaz de apenas 18 anos. É interessante notar que o esquete 
anterior e esse parecem narrar a trajetória do personagem Carlos, de Amar verbo intransitivo. Primeiro é a passagem da infância para a maturidade, depois a desilusão, semelhante à de Carlos com a partida de Elza. Do texto teatral, Primeiro Amor conserva a divisão em cenas, mas sua estrutura é de narrativa. Há uma única fala de outro personagem, mas semelhante a uma lembrança. O narrador onisciente chega a fundir-se ao personagem, e vivenciar as inquietações do abandono e da desilusão amorosa. Na segunda cena, Carlito está em seu quarto, e dorme. Dormindo, sonha com uma mulher nua, de interessante figura, cujo corpo confunde-se com uma paisagem litorânea. Sobre esse sonho, Telê Ancona Lopez escreve em sua tese:

Sonho estrutural e estilisticamente bem construído, pois busca apenas a coerência interna, mostrando a ausência de lógica e o sobressalto do adolescente nas frases abertas em reticências. ${ }^{297}$

E "Carlito acordou". Acordou com o desejo de beijar aquela mulher, mas ao olhar-se no espelho, o espelho parecido com um "grande olho de cego, muito aberto", enxergou-se e desatou a chorar. Nesse momento, o narrador retoma sua autonomia e exclama, demonstrando compaixão: "Criança!".

Deixamos para o final o quarto esquete da série por ser o único não assinado por Mário de Morais Andrade, mas por Eufrazio Pessôa, o qual julgamos ser um pseudônimo do escritor. Teus parentes, publicado em agosto de 1919, possui ares de comédia e é despretensioso como Viúva Alegre. O enredo traz a história do Doutorzinho, um jovem de 26 anos, recém-formado em Direito, "magro, calmo e triste", que mora com sua mãe, Dona Mercedes, cujos cabelos são "mais alvos do que os lírios úmidos do Cubatão" e as faces "mais rugosas do que um campo arado". O Doutorzinho vive de advogar a causa dos parentes, como o tio, Pedro Xavier; o primo em segundo grau, Luís Felipe; e Seu Vicente, primo em quinto grau. Todos se favorecem dos serviços do advogado, mas na hora do pagamento, esquecem a relação advogado-cliente, e valem-se do parentesco.

297 LOPEZ, Telê Ancona. Op. cit. p.86 
Como paga pelos serviços prestados, o Doutorzinho recebe ora um peru, ora um saco de laranjas, ora um muito obrigado.

O rapaz, por não receber um nome e ser chamado apenas de Doutorzinho, passa a valer mais como um tipo, a representar toda uma categoria, a dos advogados recém-formados, em busca de se estabelecer na profissão.

Traços característicos da escrita de Mário de Andrade, como a religiosidade, o uso freqüente de reticências, da linguagem informal, de metáforas para descrever os personagens, estão presentes em Teus parentes, o que nos leva a crer na hipótese de esse texto ser realmente de sua autoria.

Eva, o esquete mais conhecido do escritor, é publicado em Papel e Tinta, em fevereiro de 1921, um pouco mais de um ano após a publicação de Primeiro Amor. Entretanto, quando o texto é reunido a Primeiro Andar, constará a data 1919. Infelizmente, não há a numeração do texto, como havia em $O$ Echo, portanto, não é possível saber se esse seria o primeiro, o oitavo esquete, ou se outros foram publicados nesse ínterim entre Primeiro Amor e a data da publicação da revista. Na seção "Letras Sul-Americanas", da revista, o cabeçalho informa: Eva. Dos "Virtuosos e Farrapilhas", e traz, ao final, a assinatura de "Morais de Andrade (Brasil)", recurso utilizado para dar ao leitor a impressão de que a revista possuía vários colaboradores, inclusive estrangeiros. Chama-nos atenção a inscrição "Dos Virtuosos e Farrapilhas" (grifo nosso), pois fazendo uma análise, gramatical e lingüística, o artigo "os", somado à preposição "de", traz uma carga semântica de familiaridade, que não existiria se usada somente a preposição "de", ou seja, o artigo definido exerceria uma função dêitica em relação ao nome designado, dando a impressão de que o nome já era conhecido. Essa é somente uma hipótese, assim como se pode levantar outra possibilidade, a de que Eva possa ser o primeiro esquete, escrito em 1919, mas reescrito, reelaborado pelo autor, como era um costume seu, e publicado no momento em que ele ficou satisfeito com sua criação. A hipótese do aperfeiçoamento pode ser pensada uma vez que foi o único esquete de Virtuosos e Farrapilhas a constar de Primeiro Andar.

Paulo e Virginia e Eva apresentam uma particularidade: a presença da alegoria "A Porta" e "O Desejo", respectivamente. Se em Eva, essa alegoria não se 
corporifica, e figura apenas como a tentação, como um elemento intrínseco à mulher, em Paulo e Virginia, esse recurso aparece mais maduro. A "Porta" distingue-se por somar características animadas e inanimadas: solteirona, discreta, envernizada. Ademais suas falas, mesmo não se direcionando a alguém em específico, permeiam o enredo, encadeando os acontecimentos, e, ao final, inclusive, misturam-se às inquietações da consciência da madre. Conforme Telê Ancona Lopez, em Eva, "o escritor ainda não dispunha de força para lidar teatralmente com essa figura", com a alegoria ${ }^{298}$. Esse pode ser outro sustentáculo da hipótese de Eva ser o esquete primogênito, já que "A Porta" é bem mais elaborada que "O Desejo".

Telê também aponta a existência de outro esquete cuja autoria pode ser atribuída a Mário de Andrade. Femina foi publicado no número 4 de Papel e Tinta, mas não traz nenhuma assinatura. No entanto, há semelhanças que lhe apontam a autoria. Nesse texto, as personagens, Fúlvia e Clara, ex-colegas do Colégio Sion, falam de sua vida amorosa, e relembram fatos passados, trazendo à tona os seus tempos de colégio. Ao rememorar essa fase, citam o nome "Monsenhor Montroul", nome que, possivelmente, alude a "Monseigneur Sentroul", reitor da Faculdade de Filosofia e Letras, do Largo de São Bento, onde Mário estudara ${ }^{299}$.

Há outra pista remetendo-nos a pensar em Mário como o autor de Femina. Nesse caso, o narrador aproxima música e narrativa em "A orquestra toca um tango", após a intensa declaração de amor de Clara, "traída e vilipendiada", nas palavras de Telê Ancona. Da mesma forma, no final de Cravos de outubro, Alice, abandonada e sacrificada, desespera-se, e ao fundo "A música é valsa vulgar", e o piano executa "Um concerto em meio da tragédia".

A ligação entre música e narrativa surgirá habilmente manipulada em um esquete publicado em outra revista paulista, $A$ Idea ${ }^{300}$. A guitarra frustrada de Romeu. Bailado em Prosa encontra-se no arquivo Mário de Andrade, no álbum preto organizado por sua irmã. Um elemento importante, não encontrado nos outros textos, é a ilustração que acompanha o esquete, corroborando com a

298 LOPEZ, Telê Ancona, Op. cit. p. 83. 
"armadilha" preparada para o leitor. A ilustração traz um casal abraçado em pose sensual; ele com o rosto posicionado no colo da mulher, lábios encostados em seu corpo, ela com o corpo inclinado para trás, sugere um momento de êxtase. Telê afirma que o texto remete, de fato, a um bailado, pois é repleto de "ritmos poéticos, musical, plástico e coreográfico ao extremo"301. O texto oscila entre o erótico, 0 lírico, o sensorial, e reserva a comicidade para o desfecho.

O "bailado" narra um encontro entre Rita e Romeu. Romeu, quando anda, "oscila musicalmente, em ritmos longos de cipreste ao vento. Rita "tem a pele móbil como os veludos sensuais que o verão exaspera". A musicalidade permite que a movimentação dos personagens assemelhe-se a uma dança.

Romeu - (...) Dança. Bamboleia numa onda que é um langor. Curva em gestos inéditos a fita do corpo esguio. Afina-se. Alonga-se, alonga-se, e queda imóvel, como um êxtase pasmo de repuxo.

A ambigüidade das descrições, auxiliada pelos "comentários" sugestivos de uma "Guitarra", inexistente, símbolo da "inconsciência trêmula das declarações que não têm voz", aguçam a curiosidade do leitor. Esse, por sua vez, influenciado pela ilustração do casal abraçado, prossegue com a leitura sem imaginar que, na verdade, o encontro amoroso não é entre um homem e uma mulher, mas entre um casal de gatos. Essa descoberta provoca surpresa e a necessidade de uma releitura que, concluída, nos faz rir por termos sido ludibriados direitinho pelo narrador. Não é à toa que nos deixamos enganar, tudo no texto parece confirmar um encontro amoroso entre humanos. No entanto, revelada a situação, passamos a investigar o texto, e só então se torna evidente algo que estava, literalmente, diante dos nossos olhos. Não há diálogo entre Rita e Romeu, ambos se expressam através de movimentos e sensações. O texto é tão bem construído que torna o diálogo irrelevante, porém só percebemos isso depois de cairmos na armadilha do jogo textual.

301 LOPEZ, Tele Ancona. "A Memória: Mário de Andrade: Um bailado em prosa”. Petrópolis. Cultura Vozes Petropolis, v.87, n.1, p.84-91, jan./fev. 1993, p. 85. 
O quebra-cabeça forjado por Mário de Andrade não pára por aí; também nos intriga a data da redação desse esquete. O texto foi publicado em 1924, mas nos seus escritos, o criador de Macunaíma rasurou a data, trocando-a por 1916. 1924 ou 1916? Novamente recorremos aos estudos de Telê Ancona Lopez, a qual afirma que os elementos propriamente modernistas do "bailado" são traços de um autor mais consciente, envolvido com as tendências modernas, cuja criação aproxima-se de Paulicéia Desvairada e Macunaíma.

Como lidamos com um escritor preocupado com seus textos, que intervém, rasura, e busca aperfeiçoá-los, não podemos descartar a hipótese de que uma primeira versão do "bailado" tenha sido escrita, de fato, em 1916. E o autor, insatisfeito com sua criação, teria guardado o original, e publicado-o somente quando o considerou finalizado. 


\section{Conclusão}

A história do teatro brasileiro do período que se estendeu de 1901 a 1922 foi, na maior parte das vezes, retratada de forma inexpressiva. Tal situação decorreu da opinião partilhada por muitos estudiosos de que nada surgido nesse intervalo de tempo fosse merecedor de longa análise. Entretanto, há alguns anos, para o bem dos estudos teatrais, essa opinião vem se modificando. Atualmente, encontramos trabalhos como os realizados por Miroel Siveira, Roberto Ruiz, Neyde Veneziano, Elisabeth Azevedo, Claudia Braga, entre outros, que souberam valorizar as realizações teatrais desse período.

O nosso propósito foi contribuir com os estudos já realizados sobre a época mencionada. Espera-se que o tenhamos atingido, ao menos em parte. Para alcançá-lo, portanto, decidimos pesquisar os periódicos paulistas de 1901 a 1922, e coletar os registros de acontecimentos teatrais ali encontrados. Após a reunião desses dados, o próximo passo foi organizar um índice de datas e assuntos correntes nos periódicos. A partir disso, elaborar um estudo interpretativo sobre o teatro em São Paulo no início do século XX.

O teatro em São Paulo, no início do século XX, acompanhava a mentalidade do país à época. A afirmação da identidade nacional envolvia críticos, historiadores e intelectuais em uma constante busca. Esse processo incluía, portanto, os artistas e as pessoas envolvidas com o teatro. Em virtude disso, a idéia de que o Teatro Nacional estava em "decadência" permaneceu viva, desde o surgimento da opereta.

A voz comum da época divulgava que a "decadência" do teatro era fruto da perseguição ao modelo estrangeiro, dos gêneros musicados, dos números de variedades e do cinematógrafo. Sendo assim, o capítulo inicial desse trabalho investigou se esses intelectuais tinham razão ao defenderem essa idéia. Chegamos à conclusão que, mesmo que esses fatores tenham representado um obstáculo ao pleno desenvolvimento da arte dramática, não são suficientes para se afirmar que o teatro brasileiro enfrentava um período de "decadência", ou "morte" como apregoavam outros. Considerar a decadência do teatro é acreditar que ele já 
vivera um momento de glória, e o que nos parece é que, desde a fase realista - tida como gloriosa - até a fase por nós estudada, o caminho percorrido não foi descendente, mas de continuidade da produção teatral ${ }^{302}$. Diferente apenas.

Segundo Claudia Braga, a comédia, desde Aristófanes, tinha o objetivo de chamar a atenção da platéia aos desvios morais do homem. Sendo assim, prossegue a pesquisadora, a comédia deveria ser o espelho da sociedade, a mimese do homem, como afirmava Cícero. A comédia de costumes brasileira, conforme a historiadora, sempre teve o propósito de fazer rir, de agradar. No entanto, a imitação proposta teria sido imperdoável por escolher como modelo a vida e os costumes das platéias populares, em vez do Brasil "civilizado" criado pela elite ${ }^{303}$.

O público não via mais como modelo de sociedade aquele apresentado nas comédias realistas. A sua visão voltava-se agora para os motivos cômicos, populares, cujos personagens ou situações - sociais, culturais e políticas remetessem ao seu cotidiano. Os intelectuais, porém, não pensavam dessa maneira; para eles o teatro deveria primar pela moral - regida pela ética burguesa e pelos bons costumes acima de tudo.

Se o teatro brasileiro dessa época foi desvalorizado como um todo, a visão estreitava-se ainda mais quando o foco deslocava-se do Rio de Janeiro. Por ser a Capital Federal é natural que sua vida artística fosse mais intensa. Mas não se pode falar em história do teatro brasileiro com base no que acontecia em um só local. Desse modo, decidimos focalizar São Paulo, a fim de romper com esse estreito limite, e ampliar o campo geográfico desses estudos. Outro fator determinante para essa escolha foi a expansão sócio-econômica de São Paulo, decorrente da produção cafeeira e da imigração, provocadora de profundas mudanças nas feições da cidade.

Diante do panorama apresentado ao longo do trabalho, é plausível aceitar a proposição inicial de que a cidade de São Paulo ofereceu relevante produção à história do teatro brasileiro.

302 Ver BRAGA, Claudia. Teatro Brasileiro na República Velha: reflexões sobre a dramaturgia brasileira. São Paulo: Doutorado. ECA/USP, 1999 , p. 10. 
A pesquisa nas fontes primárias nos rendeu fatos concretos sobre 0 funcionamento da vida teatral nesses anos. Conseqüentemente, forneceu-nos dados para desmistificar as teorias de que o início do século XX fora infrutífero em termos teatrais, ou que a produção teatral da época fora irrelevante. Deparamo-nos com o que foi produzido e realizado efetivamente, e não nos pareceu pouco. Companhias teatrais que driblaram a concorrência estrangeira, e conseguiram se manter por anos em atividade; inúmeros textos de teatro musicado ou regionalista, reveladores de revisteiros e dramaturgos; aparições, mesmo que tímidas, de peças de "caráter literário". Além disso, as discussões travadas entre os intelectuais sobre a situação do teatro nacional podem ser compreendidas como um instrumento a mais de preservação dessa arte. Afinal, serviram para manter os holofotes voltados ao teatro brasileiro.

Estávamos sempre com os olhos no passado, lamentando os bons tempos que se foram, e almejando que voltassem. No entanto, os intelectuais do passado sofriam do mesmo mal. Em 1873, Machado de Assis desabafava:

[O Teatro] Esta parte pode reduzir-se a uma linha de reticência. ${ }^{304}$

Essas projeções nostálgicas vinham repletas de ilusões sobre um passado ideal, em que o teatro vivera um período áureo. O que nos fez lembrar alguns versos do soneto Velho Tema, de Vicente de Carvalho:

$[\ldots]$

O eterno sonho da alma desterrada,

Sonho que a traz ansiosa e embevecida,

É uma hora feliz, sempre adiada,

E que não chega nunca em toda a vida.

Essa felicidade que supomos,

Árvore milagrosa que sonhamos

Toda arreada de dourados pomos,

Existe, sim: mas nós não a alcançamos

Porque está sempre apenas onde a pomos

E nunca a pomos onde nós estamos. ${ }^{305}$

304 ASSIS, Machado, artigo citado.

305 CARVALHO, Vicente. Poesia, Rio de janeiro, Livraria Agir Editora, 1965. 


\section{Bibliografia}

AMARAL, Antônio Barreto do. História dos velhos Teatros de São Paulo: da Casa da Ópera à inauguração do Teatro Municipal. São Paulo: Governo do Estado, 1979.

ANDRADE, Mário. Poesias completas. São Paulo: Martins em convênio com o Instituto Nacional do Livro/ MEC, 1972

, Mário. Amar, verbo intransitivo: idílio. São Paulo: Livraria Martins editora, 1944.

, Mário. Os contos de Belazarte. São Paulo: Livraria Martins Editora, 1947.

, Mário. Contos novos. São Paulo: Livraria Martins Editora, 1947.

, Mário. Obra imatura. São Paulo: Martins, 1960.

, Mário. Paulicéia Desvairada. São Paulo: Casa Mayença, 1922.

, Mário. Primeiro Andar. São Paulo: Casa Ed Antonio Tisi, 1926.

, Mário. Quatro pessoas: romance inacabado. Belo Horizonte: Itatiaia, 1985.

ANDRADE, Oswald de. Mon Coeur balance; Leur âme, São Paulo: Globo, 2003.

ANTUNES, Delson. Fora do Sério: Um Panorama do Teatro de Revista no Brasil. Rio de Janeiro: Funarte, 2002.

BILAC, Olavo. Antologia Poética. Rio de Janeiro: Francisco Alves, 1913.

Olavo. Tarde. Rio de Janeiro: Francisco Alves, 1919.

BOSI, Alfredo. História concisa da Literatura Brasileira. São Paulo: Editora Cultrix, 1994. 
BRAGA, Claudia. Teatro Brasileiro na República Velha: reflexões sobre a dramaturgia brasileira. São Paulo: Doutorado. ECA/USP, 1999.

BRITO, Mário da Silva. História do Modernismo Brasileiro. Rio de Janeiro: Editora Civilização Brasileira, 1964.

BROCA, Brito. A vida literária: 1900. Rio de Janeiro: José Olímpio, 1975.

CAMARGOS. Márcia Mascarenhas de Rezende. A Villa Kyrial e o imaginário da Belle Époque paulistana. (1900-1930). São Paulo: Doutorado. História/ FFLCH/USP,1999.

CANDIDO, Antonio. A Educação pela noite e outros ensaios. São Paulo: Ática, 1987.

Antonio. Literatura e sociedade: estudos de teoria e história literária. São Paulo:

T. A. Queiroz, 2000.

CARVALHO, Vicente. Poesia. Rio de Janeiro: Livraria Agir Editora, 1965.

CASTELLO, José Aderaldo. "A Pesquisa de periódicos na Literatura Brasileira". In; NAPOLI, Roselis Oliveira de. Lanterna Verde e o Modernismo. São Paulo: IEB/USP, 1970.

CRUZ, Heloísa Faria. São Paulo em Revistas: catálogo de publicações da imprensa cultural e de variedade paulistana-1870/1930. São Paulo: Arquivo do Estado, 1997.

DIMAS, Antonio. Espaço e Romance. São Paulo: Editora Ática, 1985.

Antônio. Tempos Eufóricos: análise da revista Kosmos-1904/1919. São Paulo: Ática, 1983.

FARIA, João Roberto. As idéias teatrais no Brasil: O século XIX no Brasil. São Paulo: Editora Perspectiva, 2001. 
João Roberto. "Mário de Andrade e a questão da língua brasileira". In: Estudos sobre o Modernismo. Curitiba: Criar, 1982.

FRAGA, Eudinyr. "As peças em francês". In: ANDRADE, Oswald \& ALMEIDA, Guilherme de. Mon coeur balance e Leur Âme. Editora Globo, São Paulo, 2003.

GIRON, Luís Antônio. Ensaio de ponto: recortes carnavalescos por Saturnino Praxedes, ex-funcionário da Companhia Nacional de Burletas \& Revistas do Teatro São José. São Paulo: Editora 34, 1998.

GOMES, José Maria Barbosa. Mário de Andrade e a revolução da linguagem: a gramatiquinha da fala brasileira. João Pessoa: Editora Universitária/UFPb, 1979.

GOMES, Tiago de Melo. Um Espelho no palco: Identidades Culturais e Massificação da Cultura no Teatro de Revista dos anos 1920. Campinas: Editora da Unicamp, 2004.

JUNIOR, R. Magalhães. As mil e uma vidas de Leopoldo Fróis. São Paulo: Lisa-Livros Irradiantes S. A., 1917.

LEITE, Lígia Chiappini Moraes. O foco narrativo (ou A polêmica em torno da ilusão). São Paulo: Ática, 1985.

LOBATO, Monteiro. A Barca de Gleire: Quarenta Anos de Correspondência Literária entre Monteiro Lobato e Godofredo Rangel. São Paulo: Brasiliense, 1948, p. 11.

LOPEZ, Telê Ancona (org.). De São Paulo: cinco crônicas de Mario de Andrade, 19201921. São Paulo: Editora Senac, 2004.

, Telê Ancona. Mário de Andrade. Cronista na imprensa. Tese de Livre Docência apresentada ao Departamento de Literatura Brasileira, da FFLCH-USP, 1991. Telê Ancona. Mariodeandradiando. São Paulo: Hucitec, 1996. 
Telê Ancona. Mário de Andrade cronista do modernismo: 1920-1921. Literatura e Sociedade. São Paulo, n.7, p.266-294, 2003/2004.

, Telê Ancona. "A Memória: Mário de Andrade: Um bailado em prosa". Petrópolis. Cultura Vozes Petropolis, v.87, n.1, p.84-91, jan./fev. 1993.

LUCA, Tânia Regina de. A Revista do Brasil: um diagnóstico para a (N)ação. São Paulo: Doutorado, História, FFLCH, USP, 1996.

MADEIRA, Wagner Martins. Formas do teatro de comédia: A obra de Oduvaldo Vianna. São Paulo: Doutorado, Letras, FFLCH/USP, 2003.

MAGALDI, Sábato \&.VARGAS, Maria Thereza. Cem anos de Teatro em São Paulo. São Paulo: Editora Senac,2000.

, Sábato. Panorama do Teatro Brasileiro. São Paulo: Difusão Européia do livro, 1962.

MARINHO. Henrique. O Teatro Brasileiro: Alguns Apontamentos para a sua História. Rio de Janeiro, Garnier, 1904.

MARTINS, Ana Luiza. Revistas em Revista: Imprensa e Práticas Culturais em tempos de República, São Paulo (1890-1922). São Paulo: Edusp, Fapesp, Imprensa Oficial do Estado, 2001.

NUNES, Mário. 40 anos de teatro. Rio de Janeiro: SNT, 1956, vol. 1.

ORTIZ, Renato. O popular e o nacional. Cultura brasileira e indústria cultural. São Paulo: Brasiliense, 1988.

PAIXÃO, Múcio. O teatro no Brasil. Rio de Janeiro: Brasília Editora, s.d.

PAVIS, Patrice. Dicionário de Teatro. São Paulo: Perspectiva, 1999. 
PINTO, Maria Inez Machado Borges. "Cinematógrafos: O cinema e a construção da brasilidade moderna na Belle Époque". In: Estudos de História. Franca: v.4, n. 2, 1997, p.121-132.

POUILLON, Jean. O Tempo no Romance. São Paulo: Editora Cultrix, 1964.

PRADO, Décio de Almeida. História concisa do teatro brasileiro: 1570-1908. São Paulo: Editora da Universidade de São Paulo, 2003, p.102.

, Décio de Almeida. Teatro de Anchieta a Alencar. São Paulo: Editora Perspectiva, 1993.

, “O teatro em São Paulo". In: Marcondes, J.V.F. \& Pimentel, O. São Paulo. Espírito. Povo. Instituições. São Paulo: Livraria Pioneira Editora, 1968.

PRADO, Paulo. Paulística etc. São Paulo: Companhia das Letras, 2004.

RIO, João do. Comédias. Edição preparada por Orna Messer Levin. São Paulo: Martins Fontes, 2002.

SAINT-PIERRE, Bernardin de. Paulo e Virginia. Boaventura, Rosa Maria, tradução. São Paulo: Cone, 1986.

SALIBA, Elias Thomé Raízes do riso: a representação humorística do dilema brasileiro - da belle époque aos primeiros tempos do rádio. São Paulo: Companhia das Letras, 2002.

, Elias Thomé. "Nos tempos de Villa Kyrial". In: Revista USP, n.50, junho/ agosto 2001, pp. 303-307.

SILVA, Níobe Abreu Peixoto da. João do Rio e o palco : crítica teatral e dramaturgia São Paulo: Doutorado, Letras, FFLCH/USP, 2003.

SILVEIRA, Miroel. A Contribuição italiana ao teatro brasileiro, 1895-1964. São Paulo: Edições Quíron, 1976. 
SOUSA, J. Galante. O Teatro no Brasil. Rio de Janeiro: INL, 1960.

SOUZA, Cláudio de. "Clássicos no teatro". In: Revista da Língua Portuguesa, ano IV, número 19, setembro de 1922, pp. 275-292.

,Cláudio de. "Os estrangeirismos em nosso teatro". In: Revista da Língua Portuguesa, ano I, número 5, maio de 1920, pp. 115-120.

VARGAS, Maria Thereza. O Teatro operário na cidade de São Paulo. São Paulo: Prefeitura do Município de São Paulo. Secretaria Municipal de Cultura, 1980.

VENEZIANO, Neyde. De pernas para o ar: O Teatro de Revista em São Paulo. São Paulo: Imprensa Oficial, 2006.

, Neyde. Não adianta chorar. Teatro de Revista Brasileiro...Oba! Campinas: Editora da UNICAMP, 1996.

, Neyde. O teatro de revista no Brasil. dramaturgia e convenções. Campinas: Editora da Unicamp: Pontes, 1991.

VICTORINO, Eduardo. Atores e atrizes. Rio de Janeiro: A noite Editora, 1937, p. 85. 


\author{
UNIVERSIDADE DE SÃO PAULO \\ FACULDADE DE FILOSOFIA, LETRAS E CIÊNCIAS HUMANAS \\ DEPARTAMENTO DE LETRAS CLÁSSICAS E VERNÁCULAS \\ PROGRAMA DE PÓS-GRADUAÇÃO EM LITERATURA BRASILEIRA
}

\title{
Um resgate do Teatro Nacional \\ O Teatro Brasileiro nas revistas de São Paulo
}

(1901-1922)

\section{Maira Mariano}

Dissertação apresentada ao Programa de Pós-

Graduação em Literatura Brasileira, do

Departamento de Letras Clássicas e

Vernáculas, da Faculdade de Filosofia, Letras e

Ciências Humanas da Universidade de São

Paulo, para a obtenção do título de mestre em

Letras.

Orientador: Prof. Dr. João Roberto Gomes de Faria

\author{
São Paulo \\ 2008
}

Volume II 


\section{Sumário}

$\begin{array}{ll}\text { Índice } & 03\end{array}$

Álbum Imperial 04

$\begin{array}{ll}\text { Almanaque de Casa Branca } & 04\end{array}$

Almanaque do Estado de São Paulo $\quad 04$

$\begin{array}{ll}\text { Almanaque de Franca } & 04\end{array}$

Almanaque histórico-literário do Estado de São Paulo 04

Almanaque llustrado de São Paulo $\quad 04$

Almanaque Melillo 04

Almanaque d'oeste do Estado de São Paulo $\quad 04$

Almanaque Paulistano 05

Almanaque Paulista llustrado 05

Arquivo llustrado 05

$\begin{array}{ll}\text { A Cigarra } & 05\end{array}$

Correio Musical Brasileiro 11

O Echo 13

Éden/ Revista Theatral e Cinematográfica 18

$\begin{array}{ll}\text { Gazeta Artística } & 19\end{array}$

$\begin{array}{lr}\text { Ilustração Paulista } & 20\end{array}$

Íris $\quad 33$

Klaxon $\quad 34$

O Monóculo $\quad 34$

A Novella Semanal $\quad 34$

O Palco llustrado $\quad 35$

Papel e Tinta $\quad 35$

A Paulicéia Moderna 36

O Pirralho 36

$\begin{array}{ll}\text { O Queixoso } & 71\end{array}$

$\begin{array}{ll}\text { Revista do Brasil } & 73\end{array}$

$\begin{array}{ll}\text { Revista Feminina } & 77\end{array}$

$\begin{array}{ll}\text { Revista Nacional } & 77\end{array}$

$\begin{array}{ll}\text { Revista Santa Cruz } & 77\end{array}$

Revista Teatral/ Teatro, Sport, Arte e...o que for 78

$\begin{array}{ll}\text { Revistinha } & 79\end{array}$ 
A Ronda

79

A Vida Moderna

80

Vida Paulista

87 


\section{Índice}

\section{O Teatro Brasileiro nas revistas de São Paulo: 1901-1922.}

Este presente volume traz o índice das revistas consultadas, contendo uma síntese dos temas relativos ao teatro, abordados por escritores e intelectuais desse período. A organização dos dados seguiu o esquema definido abaixo:

1. Peças de teatro, homenagens à classe teatral: poemas e dedicatórias, escritos diversos de autores consagrados

2. Noticiário

2.1. Notícias e Notas (informações gerais sobre a vida teatral)

3. Crítica Teatral (opinião dos intelectuais, críticos, jornalistas em relação ao teatro produzido na época)

3.1. Sobre a "decadência" do teatro nacional, peça teatrais, o trabalho de atores, dramaturgos, diretores

4. Entrevistas, enquetes

5. Fotos e charges 
1. Álbum Imperial, 1906

Acervo: IEB

Nada consta

\section{Almanaque de Casa Branca, 1904}

Acervo: IEB

Nada consta

\section{Almanaque do Estado de São Paulo, 1916}

Acervo: IEB

Nada consta

\section{Almanaque de Franca, 1902}

Acervo: IEB

Nada consta

\section{Almanaque histórico-literário do Estado de São Paulo, 1903}

Acervo: IEB

5.1. Peças de teatro, homenagens à classe teatral, escritos diversos de autores consagrados

5.1.1. LEAL, Arlindo. De que se morre mais em São Paulo?

\section{Almanaque llustrado de São Paulo, setembro de 1902}

Acervo: IEB

6.1.Peças de teatro, homenagens à classe teatral, escritos diversos de autores consagrados

6.1.1 Apontamentos de uma atriz sobre sua carreira. (p.123) 


\section{Almanaque Melillo, 1904}

Acervo: IEB

Nada consta

\section{Almanaque d'oeste do Estado de São Paulo, 1906}

Acervo: IEB

Nada consta

\section{Almanaque Paulistano, 1904}

Acervo: IEB

Nada consta

\section{Almanaque Paulista llustrado, 1896}

Acervo: IEB

Nada consta

\section{Arquivo llustrado, número 3, 06 de maio de 1899, ano $\mathrm{I}$.}

Acervo: Biblioteca Mário de Andrade

11.1. Peças de teatro, homenagens à classe teatral, escritos diversos de autores consagrados

11.1.1. LEAL, Arlindo. Galãs à força.

Comédia em três atos, dedicada aos atores Matos e Peixoto. Nesse número consta somente o ato I, e as cenas I e II (ilegíveis). A peça continua nos números seguintes, é interrompida após dezembro de 1899, e dá prosseguimento de abril a julho de 1900. Em outubro de 1900, número 20, continua o terceiro ato, o qual só tem continuidade no número 24, de janeiro e fevereiro de 1901. A revista a partir desse momento passa a ser bimestral. O final da peça consta no número XXX (agora em algarismo romano), de janeiro de 1902.

11. Arquivo llustrado, número 51, 1906, página 40.

11.2. Notícias

11.2.1. Brazil Theatro 
Coletânea pelo Dr. Pires de Almeida (1901-1902) dedicado à atriz Lucília Simões.

\section{A Cigarra, número 62, 14/03/1917, ano III}

Acervo: Biblioteca Nacional

12.3. Crítica Teatral

12.3.1. Companhia Dramática de São Paulo

Artigo sobre o surgimento da Companhia organizada por Gomes Cardim, que discute como essa iniciativa pode ajudar a criar o teatro nacional.

\section{A Cigarra, número 63, 28/03/1917, ano III.}

\subsection{Crítica Teatral}

\subsubsection{O Teatro Nacional}

A crítica aborda a organização da Companhia Dramática de São Paulo, organizada por Gomes Cardim. Essa iniciativa, segundo seu autor, é uma tentativa de reerguer o teatro brasileiro.

\section{A Cigarra, número 64, 18/04/1917, ano IV}

\subsection{Crítica Teatral}

\subsubsection{Dr. Cláudio de Souza}

A crítica tece elogios à representação da peça $A$ Renúncia, de Cláudio de Souza.

12.3.2 LEÃO, Carneiro. Teatro Nacional

O artigo louva a iniciativa tomada por São Paulo de "criar" o Teatro Nacional. Discorre sobre a "decadência" do teatro causada pela representação de revistas de ano, e de como a organização da Companhia Dramática Paulista reabilitará o teatro brasileiro. Destaca também o papel de Itália Fausta como grande atriz dramática.

\section{A Cigarra, número 66, 19/05/1917, ano IV}

\subsection{Crítica Teatral}

12. 3.1. Companhia Dramática de São Paulo

O artigo comenta o êxito alcançado pela Companhia de Gomes Cardim, e ressalta o sucesso da representação de $A$ Caipirinha, de Cesário Motta Junior.

12.5. Fotos

12.5.1 Foto de uma cena do terceiro ato de $A$ Caipirinha

12.5.2. Foto de Gomes Cardim 


\section{A Cigarra, número $67,31 / 05 / 1917$, ano IV}

\subsection{Crítica Teatral}

12.3.1. Itália Fausta

Homenagem feita pela revista à Itália Fausta. O artigo elogia a atuação da atriz frente à Companhia Dramática de São Paulo, e comenta como o público paulista soube lhe apreciar o trabalho.

12.5. Foto

12.5.1. Foto de Itália Fausta

\section{A Cigarra, número $68,14 / 06 / 1917$, ano IV}

12.5 Foto

12.5.1. Foto da festa do Centenário da comédia Flores de Sombra, no Trianon, do Rio de Janeiro. Nela, aparece o ator Leopoldo Fróes fazendo a saudação oficial.

\section{A Cigarra, número $72,10 / 08 / 1917$, ano IV}

12.2. Noticiário

12.2.1. Teatros

Coluna Teatral que registra as peças e companhias em cartaz na cidade. Destaque para a Companhia de André Brulé, no Municipal.

\section{A Cigarra, número $84,30 / 01 / 1918$, ano IV}

\subsection{Noticiário}

\subsubsection{Pelos Teatros}

Comentários a respeito das peças em cartaz nos teatros da cidade. Destaque para a Companhia Arruda no Boa Vista.

\section{A Cigarra, número $86,28 / 02 / 1918$, ano IV}

\subsection{Noticiário}

\subsubsection{Pelos Teatros}

$\mathrm{Na}$ coluna teatral, o destaque vai para a Companhia Arruda, que conquistava o público com as representações de Gente Moderna e São Paulo Futuro. O anúncio chama a atenção para os ensaios de Na Piririca, revista de Danton Vampré, M. Dó e Olavo de Paula.

No teatro Avenida estréia da Companhia Nacional de Operetas, de Eduardo Victorino. No elenco, a atriz Abigail Maia. 


\section{A Cigarra, número $87,13 / 03 / 1918$, ano IV}

\subsection{Noticiário}

\subsubsection{Pelos Teatros}

Anúncio da estréia da Companhia Carrara. Nessa seção também se anuncia a exibição de filmes no teatro Royal e no teatro São Paulo.

\section{A Cigarra, número $95,12 / 07 / 1918$, ano V}

12.1 Peças de teatro, homenagens à classe teatral, escritos diversos de autores consagrados

12.1.1 Poema de Casemiro de Abreu, escrito em 1858, a um jovem ator nacional.

12.3. Crítica Teatral

12.3.1. Artigo sem título que comenta a ascendência do cinematógrafo em oposição à "decadência" do teatro.

\section{A Cigarra, número $97,14 / 08 / 1918$, ano V}

\subsection{Crítica Teatral}

12.3.1. O artigo tece elogios à peça Luizinha, de Vicente de Carvalho.

\section{A Cigarra, número 112, 15/05/1919, ano VI}

\subsection{Crítica Teatral}

12.3.1. Uma festa de elegância e arte. O Contratador de Diamantes.

$O$ artigo trata dos ensaios da peça a ser representada no Municipal pelas senhoras e senhores paulistanos.

\section{A Cigarra, número $113,15 / 06 / 1919$, ano VI}

\subsection{Fotos}

12.5.1. Duas fotos da encenação de O Contratador de Diamantes.

\section{A Cigarra, número $120,15 / 09 / 1919$, ano VI}

12.1. Peças de teatro, homenagens à classe teatral, escritos diversos de autores consagrados 12.1.1. ANDRADE, Mário Morais de.Ouro Preto (Do Trípico Mineiro).

\section{Conto}

12.5. Fotos

12.5.1. Foto de João Felizardo Junior e do maestro Modesto Tavares de Lima, autores da burleta Nossa Terra, levada no Boa Vista. 


\section{A Cigarra, número 126, Natal-1919, ano VI}

12.1. Peças de teatro, homenagens à classe teatral, escritos diversos de autores consagrados 12.1.1. ANDRADE, Mário Morais de. O Queijo.

Conto

12. A Cigarra, número $164,15 / 07 / 1921$, ano VIII

12.2. Notícias

12.2.1. Notícia da morte de João do Rio.

12. A Cigarra, número $172,15 / 11 / 1921$, ano VIII

12.5. Fotos

12.5.1. Foto de Armando Gomes de Araújo, autor da peça $O$ que os olhos dizem..., representada pela Companhia Arruda.

12. A Cigarra, número $183,01 / 05 / 1922$, ano IX

12.2. Noticiário

12.2.1. DAMANTE, Francisco. $A$ vida de uma gloriosa artista.

O artigo fala sobre a carreira da atriz Eleonora Duse e seu envolvimento com Gabriel D’Annunzio.

12. A Cigarra, número $186,15 / 06 / 1922$, ano $X$

12.2. Noticiário

12.2.1. Francisco Damante escreve um artigo elogiando a atriz Sarah Bernhardt.

12.2.2. Uma nota comenta o sucesso da temporada da Companhia Dramática Francesa do Teatro de Vaudevilles de Paris. A peça de estréia foi La Tendresse, de Bataille.

12. A Cigarra, número $193,01 / 10 / 1922$, ano $X$

12.3. Crítica Teatral

12.3.1. O artigo comenta a carreira de Oduvaldo Vianna à frente da Companhia Brasileira de Comédia.

\section{A Cigarra}

Segue abaixo a relação dos números consultados, mas que não trazem nenhuma informação sobre teatro.

número 60, 15/02/1917, ano III 
número 61, 28/02/1917, ano III

número 65, 30/04/1917, ano IV

número 69, 28/06/1917, ano IV

número $70,11 / 07 / 1917$, ano IV

número $71,26 / 07 / 1917$, ano IV

número 75, 18/09/1917, ano IV

número $77,11 / 10 / 1917$, ano IV

número 80, 18/09/1917, ano IV

número 89, 16/04/1918, ano $\mathrm{V}$

número 94, 28/06/1918, ano V

número 102, 29/11/1918, ano V

número 105, 01/02/1919, ano $\mathrm{V}$

número 106, 15/02/1919, ano $\mathrm{V}$

número 108, 15/03/1919, ano V

número 110, 15/04/1919, ano VI

número 111, 01/05/1919, ano VI

número $114,15 / 06 / 1919$, ano $\mathrm{VI}$

número 117, 01/08/1919, ano VI

número 119, 01/09/1919, ano VI

número 121, 01/10/1919, ano $\mathrm{VI}$

número 122, 15/10/1919, ano VI

número 123, 01/11/1919, ano VI

número 124, 15/11/1919, ano $\mathrm{VI}$

número 125, 01/12/1919, ano VI

número 128, 2º número de janeiro de 1920, ano VII

número 129, 1ำ número de fevereiro de 1920, ano VII

número 130, 2ำ número de fevereiro de 1920, ano VII

número 131, 1ำ número de março de 1920, ano VII

número 133, 1ํ número de abril de 1920,ano VII

número 134, 2ํㅡómero de abril de 1920 , ano VII

número 135, 1ํ número de maio de 1920, ano VII

número 136, $2^{\circ}$ número de maio de 1920 , ano VII

número 137, 1ํ número de junho de 1920, ano VII

número 138, 2º número de junho de 1920, ano VII

número 139, 1ํ número de julho de 1920, ano VII

número 140, 2º número de julho de 1920, ano VII 
número 141, 1ํ número de agosto de 1920, ano VII

número 142, 2o número agosto de 1920, ano VII

número $143,1^{\circ}$ número de setembro de 1920, ano VII

número 144, 15/09/1920, ano VII

número 145, 01/10/1920, ano VII

número 146, 15/10/1920, ano VII

número 147, 01/11/1920, ano VII

número $148,15 / 11 / 1920$, ano VII

número 149, 01/12/1920,a no VII

número 150, 15/12/1920, ano VII

número 151, 01/01/1921, ano VIII

número 152, 15/01/1921, ano VIII

número 153, 01/02/1921, ano VIII

número 154, 15/02/1921, ano VIII

número 155, 01/03/1921, ano VIII

número 157, 01/04/1921, ano VIII

número 158, 15/04/1921, ano VIII

número 159, 01/05/1921, ano VIII

número 161, 01/06/1921, ano VIII

número 162, 15/06/1921, ano VIII

número 163, 01/07/1921, ano VIII

número 165, 01/08/1921, ano VIII

número 166, 15/08/1921, ano VIII

número 168, 15/09/1921, ano VIII

número 170, 15/10/1921, ano VIII

número 171, 01/11/1921, ano VIII

número 173, 01/12/1921, ano VIII

número 174, 15/12/1921, ano VIII

número 175, 01/01/1922, ano IX

número 176, 15/01/1922, ano IX

número 177, 01/02/1922, ano IX

número 178, 15/02/1919, ano IX

número 179, 01/03/1922, ano IX

número 181, 01/04/1922, ano IX

número 182, 15/04/1922, ano IX

número 184, 15/05/1922, ano IX 
número 185, 01/06/19222, ano X

número 187, 01/07/1922, ano $\mathrm{X}$

número 188, 15/07/1922, ano X

número 189, 01/08/1922, ano X

número $190,15 / 08 / 1922$, ano $X$

número 191, 01/09/1922, ano $X$

número 192, 15/09/1922, ano $X$

\section{Correio Musical Brasileiro, número 1, 1-15 de maio de 1921, ano I}

Acervo: IEB

13.3. Crítica Teatral

13.3.1. A inauguração do Sant'Anna, pela Companhia Clara Weiss.

Ensaio anônimo sobre as expectativas em torno da inauguração do teatro Santana e a presença da companhia Clara Weiss. (pp. 7-8)

\subsubsection{Teatros}

O artigo, de R. R. A., comenta a arquitetura e o estado de conservação dos teatros da cidade, comparando-os com a magnitude do teatro Santana, patrocinado pela Condessa Penteado. 13.3.3. Teatro Nacional - Origens e Tendências.

$\mathrm{O}$ artigo trata das origens do nosso teatro na era colonial, comparando-o com o teatro feito nesse período. (p.12)

\subsubsection{Teatro e o Centenário}

Reprodução de um inquérito feito pelo $O$ Dia, do Rio de Janeiro, com vários escritores teatrais, sobre a situação do teatro nacional. Entre os escritores estão Cláudio de Souza, Coelho Neto e Abadie Faria Rosa. (pp. 13-15)

\section{Correio Musical Brasileiro, número 2, 15-31 de maio de 1921, ano I}

\subsection{Notícias}

\subsubsection{Teatros}

Comentários sobre os espetáculos em cartaz na cidade. Destaca-se a crítica dirigida à opereta $O$ filho de meu marido, montada pela Cooperativa Italiana de Operetas, de Luigi della Guardia. (p.10)

13.3. Crítica Teatral

13.3.1. Clara Weiss 
Trata da dissolução da Companhia de Operetas de Clara Weiss. Segundo o artigo, a atriz desagradou a todos ao tomar essa atitude. (p. 7)

13.3.2 Esperança Íris. A Casta Suzanna no Lírico do Rio de Janeiro.

O artigo, assinado por O.L, critica a atuação da Companhia Esperança Íris. (pp. 7-8)

13.4 Enquetes, entrevistas

13.4.1. Teatro e o Centenário

Enquete promovida pelo O Dia, do Rio de Janeiro, e reproduzida na revista. As perguntas versavam sobre o teatro brasileiro do momento. Entre os intelectuais participantes estavam Cláudio de Souza, Coelho Neto e Abadie Faria Rosa.

\section{Correio Musical Brasileiro, número 3, 1-15 de junho de 1921, ano I.}

\subsection{Notícias}

13.2.1. Crítica

Anúncio da estréia da companhia de Walter Mocchi, na temporada lírica oficial. (p.7)

13.2.2. Teatros

Comentários sobre os espetáculos em cartaz na cidade. (p.9)

13.3. Crítica Teatral

13.3.1. A morte de Feydeau.

O ensaio destaca a importância de Feydeau para o teatro francês. (p.13)

13. Correio Musical Brasileiro, número 4, 1-15 de julho de 1921, ano I.

13.2. Notícias

13.2.1. Teatros

Comentários sobre os espetáculos em cartaz na cidade. (p.7)

13.2.2. Informes

Divulgação da abertura da Escola de Canto Teatral, no Rio de Janeiro, cujo objetivo é fazer o aluno ter "a completa posse do manejo do seu órgão vocal para uso teatral". (p.7)

13.2.3. Variedades

Notícia sobre a companhia do ator Alexandre Azevedo e sua estréia no Phenix, no Rio de Janeiro. (pp.13-14)

13.2.4. Exterior

Comentários sobre a situação do teatro em Roma e Madrid. (p.14)

13.3. Crítica Teatral

13.3.1. Críticas. Dois críticos. 
Transcrição de uma crônica de S. de N., colaborador de um jornal do Rio de janeiro. A crônica pretende destacar os autores nacionais desconhecidos pelo público. (p.6)

13. Correio Musical Brasileiro, número 5, ano I, julho-agosto de 1921

13.2. Notícias

13.2.1. Teatros

13.2.2. Leopoldo Fróes em São Paulo

Anúncio sobre a estréia do ator no teatro Casino. (p. 11)

13.3.3. Variedades. Teatro Nacional

Apresentação de um projeto elaborado por Pio Dutra, visando à valorização teatro nacional. (p.13)

14. O Echo, número 82 , dezembro/1908, ano IX, p. 14

Acervo: Biblioteca Nacional

14.1. Peças de teatro, homenagens à classe teatral, escritos diversos de autores consagrados

14.1.1. AZEVEDO, Artur. Desculpa-me.

Soneto de Artur Azevedo

14. O Echo, número 98 , junho de 1910 , ano $X$

14.3.1. Os Teatros Novos

Antonio Piccarolo critica a suntuosidade do Teatro Municipal do Rio de Janeiro e de São Paulo, que afasta o público da arte, por não ser condizente com a realidade financeira do público freqüentador de teatro. (p.11)

14. $O$ Echo, número 99-100, julho-agosto de 1910 , ano $X$

14.2. Notícias

14.2.1. Notícias sobre a temporada lírica em Buenos Aires. (p.7)

14. O Echo, número 2, agosto de 1916, ano XV

14.2. Notícias

14.2.1. Temporada oficial

O artigo trata da vinda do artista francês Lucien Guitry a São Paulo. O articulista Paulo de S. Paulo faz um longo comentário, repleto de elogios, sobre o artista e seus espetáculos.

14.2.2. O Teatro no mês 
Comentários sobre as peças em cartaz na cidade.

\title{
14. O Echo, número 3 , setembro de 1916, ano XV
}

\subsection{Notícias}

14.2.1. Teatros

O texto trata da temporada de Lucien Guitry no Municipal.

\section{O Echo, número IV, outubro de 1916, ano XV}

\author{
14.2. Notícias
}

14.2.1. Teatros

A seção destina-se a comentar os cartazes dos teatros paulistanos. Destacam-se Lucien Guitry, e a atuação de Aura Abranches à frente de sua Companhia, no teatro São José.

\section{O Echo, número VII, janeiro de 1917 , ano XV}

\subsection{Crítica Teatral}

\subsubsection{Flores de Sombra}

O artigo trata do sucesso da peça de Cláudio de Souza, em cartaz no Boa Vista, e ressalta a importância dessa obra para a revitalização do teatro nacional.

14.3.2. A Moral nos Teatros. Como a entendem os Yankes. Um exemplo que devemos imitar.

Relato da proibição de duas peças, em Nova lorque, por serem consideradas imorais. Essa atitude, conforme o autor do artigo, deveria ser copiada por nós.

14.5. Fotos

14.5.1. Foto de uma cena de Flores de Sombra.

\section{O Echo, número VIII, fevereiro de 1917, ano XV}

14.3. Crítica Teatral

\subsubsection{As mulheres autoras dramáticas}

O ensaio destaca os nomes de algumas autoras dramáticas, e comenta a falta de aceitação de obras escritas por mulheres.

\section{O Echo, número IX, março de 1917, ano XV}

14.1. Peças de teatro, homenagens à classe teatral, escritos diversos de autores consagrados 14.1.1. Terceiro ato, cena 5 da peça $A$ Renúncia. Segundo a revista, a publicação foi realizada em primeira mão.

14.3. Crítica Teatral 


\subsubsection{Teatro Nacional. A Renúncia}

Aldinio Jurema elogia a montagem da peça $A$ Renúncia, de Cláudio de Souza. O artigo também defende a valorização do teatro nacional, e propõe a fundação de uma escola para artistas.

\section{O Echo, número $X$, abril de 1917 , ano $X V$}

\subsection{Notícias}

14.2.1. Notícia da futura publicação completa de $A$ Renúncia, organizada pela revista.

14.2.2. Nota sobre o sucesso da peça A Comédia, de J. Brito.

14.3. Crítica Teatral

14.3.1. Teatro Nacional.

A nacionalização do teatro é o assunto deste ensaio, que elogia os esforços de Cláudio de Souza e João do Rio.

14.3.2. Flores de Sombra.

Impressões do Dr. Fogaça de Almeida acerca da peça de Cláudio de Souza.

\section{O Echo, número $\mathrm{XI}$, junho de 1917 , ano XV}

14.3. Crítica Teatral

\subsubsection{Teatro Nacional}

Reprodução de uma reportagem, publicada no Jornal do Comércio (Rio de Janeiro), sobre a peça A Renúncia, de Cláudio de Souza.

\section{O Echo, número XII, maio de 1918, ano XV}

14.3. Crítica Teatral

\subsubsection{Teatro Camoneano}

O artigo indaga por que não se representa no dia de Camões o teatro de Camões, uma vez que em outros países seus autores são sempre celebrados.

\section{O Echo, número XII, junho de 1918, ano XVI}

\subsection{Crítica Teatral}

14.3.1. Outono e primavera

O artigo, assinado por C. C., comenta a nova peça de Cláudio de Souza.

\section{O Echo, número 3 , setembro de 1918 , ano XVII}

14.1. Peças de teatro, homenagens à classe teatral, escritos diversos de autores consagrados 14.1.1. ANDRADE, Mário. Caridade. 
Soneto de Mário de Andrade.

14.3. CríticaTeatral

14.3.1. O Drama Moderno na Itália.

O artigo trata da transformação do drama nesse país.

14. O Echo, número $X$, junho de 1919 , ano XVII

14.1. Peças de teatro, homenagens à classe teatral, escritos diversos de autores consagrados

14.1.1. ANDRADE, Mário. Viúva Alegre.

Esquete de Virtuosos e Farrapilhas. (p.34- 35)

14.3. Crítica Teatral

14.3.1. O Contratador de Diamantes

Elogios à montagem da peça, seguida da reprodução de uma crítica de Artur Azevedo publicada em O País.(pp. 67-69)

14. O Echo, número I, julho de 1919, ano XVIII

14.1. Peças de teatro, homenagens à classe teatral, escritos diversos de autores consagrados

14.1.1. ANDRADE, Mário. Paulo e Virginia

Esquete de Virtuosos e Farrapilhas. (pp 2-6)

14.2.Notícias

14.2.1. A glória de um poeta

Artigo sobre L'Etincelle, tragipoema de Jacques d'Avray (Freitas Valle), representado no Municipal do Rio, pela companhia francesa Henry Burguet.

\section{O Echo, número II, agosto de 1919, ano XVIII}

14.1. Peças de teatro, homenagens à classe teatral, escritos diversos de autores consagrados 14.1.1. PESSOA, Eufrazio. Teus parentes.

Esquete de Mário de Andrade em Virtuosos e Farrapilhas. (pp.4 -6)

\section{O Echo, número III, setembro de 1919, ano XIX}

14.1. Peças de teatro, homenagens à classe teatral, escritos diversos de autores consagrados 14.1.1. ANDRADE, Mário. Cravos de Outubro.

Esquete de Virtuosos e Farrapilhas.

\section{O Echo, número IV, outubro de 1919, ano XIX}

\subsection{Crítica Teatral}


14.3.1. A moral nos teatros.

Reprodução do artigo que aparece na edição de janeiro de 1917, número VII.

\section{O Echo, número $\mathrm{V}$, novembro de 1919 , ano $\mathrm{XIX}$}

14.1. Peças de teatro, homenagens à classe teatral, escritos diversos de autores consagrados 14.1.1. ANDRADE, Mário. Brincos de juventude

Esquete de Virtuosos e Farrapilhas.

\section{O Echo, número VI, dezembro de 1919, ano XVIII}

14.1. Peças de teatro, homenagens à classe teatral, escritos diversos de autores consagrados 141.1. ANDRADE, Mário. Primeiro Amor.

Esquete de Virtuosos e Farrapilhas.

\section{O Echo}

Não há nenhuma informação sobre teatro nos números abaixo relacionados:

número 52, junho de 1906, ano V

número 66, agosto de 1907, ano VII

número 82, dezembro de 1908, ano IX

número 87 , julho de 1909, ano IX

números 95-96, março-abril de 1910, ano $X$

número 1, julho de 1916 ( $2^{\circ}$ fase), Ano XV

número $\mathrm{V}$, novembro de 1916, Ano XV

número $\mathrm{VI}$, dezembro de 1916, Ano XV

número X, maio de 1917, Ano XV

número 1, julho de 1917, Ano XVI

número III, setembro de 1917, Ano XVI

número V, novembro de 1917, Ano XVI

número VII, janeiro de 1918, Ano XVI

número VIII, fevereiro de 1918, Ano XVI

número IX, março de 1918, ano XVI

número I, julho de 1918, ano XVII

número II, agosto de 1918, ano XVII

número III, setembro de 1918, ano XVII

número V, novembro de 1918, ano XVII

número VI, dezembro de 1918, ano XVII 
número VII, janeiro de 1919, Ano XVII

\section{5. Éden revista/ Revista Theatral e Cinematográfica, número 12, março de 1915, ano} III

Acervo: Biblioteca Nacional

15.2. Notícias

15.2.1. Peças Novas

Nota sobre a nova peça de Paula Rio, autor de São Paulo em Fraldas, que se chamará Depois te explico.

15.2.2. O mês pelos teatros

Notícias sobre as peças em cartaz na cidade.

15.3. Crítica Teatral

15.3.1. Nosso teatro

Considerações sobre a fase teatral deste período. Em comparação com a anterior, em que reinavam estrelas como Vasques, Cinira Polônio, Areias, essa estaria em plena decadência, segundo o articulista.

15.3.2. A arte de representar. Os caracteres.

$\mathrm{O}$ ensaio de J. S. Coelho faz um estudo sobre temperamento e caráter, e como eles podem ser utilizados na arte.

15.3.3. Teatro Nacional

A decadência do teatro nacional é o assunto deste ensaio assinado por Jairo de Góes.

15.5. Foto

15.5.1. Fotografia da atriz Maria Alonso.

16. Gazeta Artística, número 1, 11/12/1909, ano I

Acervo: Biblioteca Mário de Andrade

16.1. Notícias

16.1.1. Teatros e Salões

Um resumo dos cartazes dos teatros paulistanos.

16. Gazeta Artística, número 2, 24/12/1909, ano I

16.2. Notícias

16.2.1. Nina Sanzi 
Comentário sobre a atuação da atriz brasileira Nina Sanzi (pg.11).

16.2.2. Teatros e Salões

Resumo da temporada no Polytheama, Moulin Rouge e Casino

16.3. Crítica Teatral

16.3.1.PICCAROLO. Antonio. Ressurgimento da opereta

Nesse artigo, o professor discute porque o público prefere as operetas ao teatro considerado literário (pp.2 e 3).

\section{Gazeta Artística, número 9, 1ำ Quinzena de Abril de 1910, ano I}

16.1. Peças de teatro, homenagens à classe teatral, escritos diversos de autores consagrados

16.1.1. O Drama do Amor, de Visconde de S. Boaventura

Peça em dois atos, extraída de um conto de Rodrigo Paganino (pg.13).

16.3. Crítica Teatral

16.3.1. PICCAROLO. Antonio Os Teatros Novos

O artigo trata da diferença do público freqüentador de teatro. Conforme o crítico, ao observar a arquitetura do Teatro Municipal do Rio e de São Paulo, verifica-se que estes teatros não teriam lugar para o povo, só balcões e camarotes. E o público da época seria o povo: a burguesia enriquecida e o proletariado.

\section{Gazeta Artística, número 10, 1e 2 Quinzena de Maio de 1910, ano I}

16.3. Crítica Teatral

16.3.1. PICCAROLO. Antonio Voltando ao Tema (Triunfo da Opereta)

O autor discorre novamente sobre a preferência do público freqüentador de teatro.

\section{Gazeta Artística, setembro de 1911, ano II}

16.3. Crítica Teatral

16.3.1. Pelos Teatros. O Municipal

O artigo comenta a má administração do teatro Municipal.

\section{Ilustração Paulista, número I, 22/10/1910, ano I}

Acervos: Biblioteca Nacional, Biblioteca Mário de Andrade

17.2. Notícias

17.2.1. Teatro, Música e Diversões 
Divulgação das peças em cartaz na cidade. Destaque para a representação de $A$ Viúva Alegre pela Companhia Lahoz, no Polytheama.

17.3. Crítica Teatral

17.3.1. Cinematógrafo

O texto aborda a morte do teatro devido à ascendência do cinematógrafo.

\section{Ilustração Paulista, número II, 29/10/1910, ano I}

\subsection{Notícias}

17.2.1. Teatro, Música, sports e Diversão

Divulgação das peças em cartaz na cidade.

17.2.2. Nota sobre uma conferência realizada por João do Rio: $A$ delícia de mentir.

\section{Ilustração Paulista, número IV, 12/11/1910, ano I}

\subsection{Notícias}

17.1.1. Teatro, Música, sports e Diversão

Divulgação das peças em cartaz na cidade.

Destaca-se o sucesso alcançado pela Companhia Lahoz, representando as operetas O Camponês Alegre e A Princesa dos dólares.

\section{Ilustração Paulista, número V, 19/11/1910, ano I}

17.2.1. Teatro, Música e Diversões

Divulgação das peças em cartaz na cidade.

Retoma-se o êxito da Companhia Lahoz no Polytheama.

\section{Ilustração Paulista, número 10, 09/03/1911, ano I}

\subsubsection{Pelos teatros}

O articulista Dom Fradique apresenta o que estava em cartaz na cidade, e discute a predileção do público pela opereta.

\section{Ilustração Paulista, número 11, 16/03/1911, ano I}

\subsection{Notícias.}

\subsubsection{Pelos teatros}

Dom Fradique comenta as peças em cartaz na cidade. Destaque para a representação das operetas Sangue d'artista e Monsieur de La Palisse. 


\section{Ilustração Paulista, número 12, 23/03/1911, ano I}

\subsection{Notícias.}

\subsubsection{Pelos teatros}

Divulgação das peças em cartaz na cidade. O destaque fica por conta do sucesso da Companhia Vitale, no Polytheama, e a Companhia Gattini-Angelini, no São José.

\section{Ilustração Paulista, número 13, 30/03/1911, ano I}

\subsection{Notícias}

\subsubsection{Pelos teatros}

Divulgação das peças em cartaz na cidade.

Destaca-se a notícia da despedida da companhia Gattini-Angelini, que após uma série de 13 espetáculos deixou o teatro São José. As operetas apresentadas com êxito pelo grupo foram: $L e$ Petits Michú, Granatiere e Mmcelle Nituche (sic). Enquanto isso, no Polytheama, a Companhia Vitale finalizava a semana com Orpheu no Inferno, de Offenbach.

\section{Ilustração Paulista, número 14, 06/04/1911, ano I}

\subsection{Notícias}

\subsubsection{Pelos Teatros}

Divulgação das peças em cartaz na cidade.

Das peças representadas mereceram especial menção $A$ vingança dum louco, título com que foi traduzido Loco Dias de Ecchegaray; e Rei maldito, de Marcelino Mesquita, pela Companhia Dramática Portuguesa de Alves da Silva.

\section{Ilustração Paulista, número 15, 15/04/1911, ano I}

\subsection{Crítica Teatral}

17.3.1. Os Progressos de São Paulo. O cinema Íris Theatre

$\mathrm{O}$ artigo aborda a crescente importância do cinematógrafo na sociedade, e como o teatro teve que ceder lugar a essa outra arte.

\section{Ilustração Paulista, número 16, 06/04/1911, ano I}

17.2. Notícias

17.2.1. Pelos Teatros

Divulgação das peças em cartaz na cidade. 
Voltou a São Paulo a Companhia Gattini-Angelini, após uma excursão a Poços de Caldas. No teatro Santana, uma companhia tedesca apresentou A Casta Suzanna, sendo bastante apreciada pela colônia alemã de São Paulo.

\section{Ilustração Paulista, número 17, 29/04/1911, ano I}

17.2. Notícias

\subsubsection{Pelos Teatros}

Divulgação das peças em cartaz na cidade.

Dessa vez comenta-se o fracasso da Companhia Gattini-Angelini, representando A Princesa dos dólares; da companhia tedesca, sem coro e repertório apropriados; e da Companhia Alves da Silva, com a peça Amor de Perdição.

\section{Ilustração Paulista, número 18, 06/05/1911, ano I}

17.1. Peças de teatro, homenagens à classe teatral, escritos diversos de autores consagrados

17.1.1. DIAS, Alberto. Agonia. Ele e Ela

Episódio descrito como um "Quadro da vida em um ato e quatro cenas".

17.2. Notícias

17.2.1. Pelos Teatros

Divulgação das peças em cartaz na cidade.

Novamente, é comentado o fracasso da Companhia Gattini-Angelini. Enquanto isso, a Companhia Città di Napoli era muito elogiada.

\section{Ilustração Paulista, número 19, 13/05/1911, ano I}

\subsection{Notícias}

\subsubsection{Pelos Teatros}

Divulgação das peças em cartaz na cidade.

Aguardava-se com ansiedade a vinda de uma companhia lusitana, assim como a de uma companhia espanhola, que viria de Buenos Aires.

Destaque para o sucesso da Companhia Città di napoli, no Polytheama.

\section{Ilustração Paulista, número 20, 20/05/1911, ano I}

\subsection{Notícias}

\subsubsection{Pelos Teatros}

Divulgação das peças em cartaz na cidade.

Elogios a para Carlo Nunziata da companhia Città di Napoli. 


\section{Ilustração Paulista, número 21, 27/05/1911, ano I}

17.2. Notícias

17.2.1. Pelos teatros

Texto ilegível.

17.5 Fotos

17.5.1. Foto de Srta. Müller, artista da Companhia Città di Napoli.

\section{Ilustração Paulista, número 22, 03/06/1911, ano I}

17.2. Notícias

17.2.1. Pelos teatros

Divulgação das peças em cartaz na cidade.

17.5. Fotos

17.5.1. Fotos de Mattos e de Mercedes Berenguer da companhia que estreara no Polytheama.

17. Ilustração Paulista, número 23, 10/06/1911, ano I

\subsection{Crítica Teatral}

17.3.1. Philosofia de teatro

O autor, baseando-se na representação de $A$ Dama das camélias, no Santana, ressalta que prefere as peças do velho teatro francês ao repertório do teatro musicado. No Polytheama, estréia a Companhia de José Ricardo com a peça $O$ Camponês Alegre. Destaque também para o fracasso da peça L'Aiglon, com a atriz brasileira Nina Sanzi, no Santana.

17.5. Fotos

17.5.1. Foto de Nina Sanzi.

17.5.2. Foto de José Ricardo e de Emília Reis da Companhia de José Ricardo.

\section{Ilustração Paulista, número 24, 17/06/1911, ano I}

17.2. Notícias

17.2.1. Pelos teatros

Texto ilegível.

\section{Ilustração Paulista, número 25, 24/06/1911, ano I}

17.1. Peças de teatro, homenagens à classe teatral, escritos diversos de autores consagrados 17.1.1. DALVA, Lúcio. Pássaros e Flores.

Sainete em ato único.

17.2. Notícias 


\subsubsection{Pelos teatros}

Destaque para a récita de José Ricardo com O Testamento da Velha.

\section{Ilustração Paulista, número 26, 01/07/1911, ano I}

17.2. Notícias

\subsubsection{Pelos teatros}

Divulgação das peças em cartaz na cidade.

O teatro São José é reaberto com a Companhia Chatelet de Paris.

\section{Ilustração Paulista, número 27, 08/07/1911, ano I}

17.5. Fotos

17.5.1. Foto de Emílio Zago: "primeira figura da companhia Veneziana que quinta-feira estreou no Polytheama".

\section{Ilustração Paulista, número 28, 15/07/1911, ano I}

\subsection{Notícias}

\subsubsection{Pelos teatros}

Divulgação das peças em cartaz na cidade.

Não foi bem recebida pelo público a Companhia Chatelet, ao contrário da Companhia de Emílio Zago, que agradou bastante. Apesar do sucesso dessa última, o colunista ressaltou que o ator não estava bem informado do gosto do público paulistano, o qual já não era mais atraído por "descoloridas pochades de riso fácil e pouca arte".

\section{Ilustração Paulista, número $31,05 / 08 / 1911$, ano I}

\subsection{Notícias}

\subsubsection{Pelos teatros}

Divulgação das peças em cartaz na cidade.

A coluna traz a informação de que, após grandes transformações, O Moulin Rouge fora contratado pela empresa Marzollo \& Companhia, cujos espetáculos seriam organizados pela Paulicéia Cinema.

\section{Ilustração Paulista, número $33,19 / 08 / 1911$, ano I}

\subsection{Notícias}

\subsubsection{Teatros}

Divulgação das peças em cartaz na cidade. 
A Companhia Galhardo do Teatro Avenida, de Lisboa, conquistou a platéia. As peças representadas a pedidos do público foram: O Conde de Luxemburgo e a Princesa dos Dólares, em que se destacou a atriz Cremilda de Oliveira.

\section{Ilustração Paulista, número 34, 26/08/1911, ano I}

19.2. Notícias

19.2.1. Teatros

Novamente o destaque vai para a Companhia Galhardo, dirigida por Assis Pacheco.

\section{Ilustração Paulista, número $35,02 / 09 / 1911$, ano I}

17.3 Crítica Teatral

17.3.1. Edição especial sobre o Teatro Municipal

Todo esse número é reservado a artigos sobre o Teatro Municipal.

\section{Ilustração Paulista, número 39, 07/10/1911, ano I}

\subsection{Notícias}

\subsubsection{Notícia teatrais}

Comentário a respeito da crítica feita pelo Correio da manhã sobre a peça Dedo do Diabo, apresentada no Chantecler do Rio. A montagem recebe elogios, sendo caracterizada como "misto de trágico, dramático (...) ensaiada pela companhia do Teatro da Natureza, nos moldes do Sr. Gemier na França".

\section{Ilustração Paulista, número 41, 28/10/1911, ano I}

\subsection{Notícias}

\subsubsection{Pelos teatros}

Divulgação das peças em cartaz na cidade.

Anúncio de estréia da Companhia Renzi Gabrielli, com a récita do drama Fonte de Suspiros, do romance de Miguel Zevacco.

\section{Ilustração Paulista, número 43, 11/11/1911, ano I}

\subsection{Notícias}

\subsubsection{Pelos teatros}

Mário Mariz comenta que "De todo o vasto Brasil, São Paulo é, ao que parece, a mais lucrativa praça teatral. Bem poucas troupes aqui tem naufragado (...) Estamos agora atravessando um período de crise, não de dinheiro, não de falta de espectadores, mas de boas companhias". 


\section{Ilustração Paulista, número 44, 18/11/1911, ano I}

\subsection{Notícias}

\subsubsection{Pelos teatros}

Mário Mariz afirma que a cena teatral não apresentava nenhuma novidade. No Santana uma troupe mambembe luso-hispano-brasileira continuava a lutar, mas, segundo o colunista, não entendiam muito do savoir-faire, uma vez que representavam Tim-Tim por Tim-Tim e Vinte e oito dias de Clarinha. Assim, não podiam reclamar da indiferença do público pela arte nacional.

\section{Ilustração Paulista, número 45, 25/11/1911, ano I}

\subsection{Notícias}

\subsubsection{Pelos teatros}

O colunista ressalta que, no momento, o teatro vivia uma crise, mas a chegada da Companhia Ettore Vitale poderia socorrer o meio artístico. No entanto, o grupo só teria êxito "se não apresentar peças que firam a moral e bons costumes com imoralidades e gestos obscenos, caso contrário só lhes restará moscas e cadeiras vazias".

\section{Ilustração Paulista, número 46, 02/12/1911, ano I}

\subsection{Notícias}

17.2.1. Pelos teatros

Mário Mariz registra a chegada da Companhia Vitale. Ele ainda reforça que a Companhia precisaria ter cuidado na representação das peças, pois nada podia ser feito às "escâncaras": "Eis porque as famílias vão ao teatro. Nas famílias paulistas ainda há muito pudor":

\section{Ilustração Paulista, número $47,09 / 12 / 1911$, ano I}

\subsection{Notícias}

17.2.1. Informes sobre a estréia da companhia Vitale com as peças $O$ Conde de Luxemburgo e Os Saltimbancos.

\section{Ilustração Paulista, número 48, 16/12/1911, ano I}

\subsection{Notícias}

\subsubsection{Pelos teatros}

Mário Mariz registra o sucesso da Companhia Vitale com as peças Amor de Zingaro, de Franz Lehar, e Casta Suzanna, de Gilbert. Destaca ainda que o Municipal continuava a funcionar como casa de chá. 


\section{Ilustração Paulista, número 49, 23/12/1911, ano I}

\subsection{Notícias}

\subsubsection{Pelos teatros}

Mário Mariz afirmou: "A grande novidade teatral é a organização do chamado sindicato lírico para trazer companhias de ópera para o já famoso Teatro Municipal que tanto dinheiro nos custou e até agora, após a sua inauguração mais ou menos auspiciosa, não tem passado de casa de chá".

\section{Ilustração Paulista, número 51, 06/01/1912, ano II}

\subsection{Notícias}

\subsubsection{Pelos teatros}

Mário Mariz registra o sucesso alcançado pela Companhia Vitale, no Polytheama; e a Companhia Marchetti, no São José.

\section{Ilustração Paulista, número 55, 03/02/1912, ano II}

\subsection{Notícias}

\subsubsection{Pelos teatros}

O colunista, sob o pseudônimo Pimpa, informa que a Companhia Vitale preparava-se para embarcar para o Rio de Janeiro. Destaque para o sucesso da Companhia Marchetti no São José.

\section{Ilustração Paulista, número 56, 10/02/1912, ano II}

\subsection{Notícias}

\subsubsection{Pelos teatros}

Notícia sobre a transformação do Polytheama em café concerto. Elogios à Companhia Marchetti, no São José, com a representação da Viúva Alegre.

\section{Ilustração Paulista, número 57, 17/02/1912, ano II}

17.2. Notícias

17.2.1. Pelos teatros

A empresa teatral South American Tour continua com enorme sucesso no Polytheama.

\section{Ilustração Paulista, número 59, 02/03/1912, ano II}

\subsection{Notícias}

17.2.1. Pelos teatros 
O Polytheama estava em alta com a representação de Mr. Harry Lyndson, com a pantomima $O$ ladrão e a polícia e os seus cachorros equilibristas. O maior acontecimento, no entanto, era o trio Davies com o círculo da morte.

O Casino continuava com a sua linha de espetáculos, privilegiando artistas de vários gêneros.

\section{Ilustração Paulista, número 60, 09/03/1912, ano II}

\subsection{Notícias}

\subsubsection{Teatros}

A sessão prossegue comentando o sucesso do Polytheama, agora com números sempre variados: de cançonetas a motociclistas.

O Casino continuava a ser o "teatro da moda", abrigo da alta sociedade paulistana.

\section{Ilustração Paulista, número 61, 16/03/1912, ano II}

\subsection{Fotos}

17.5.1. Pelos teatros

Foto de Tina da Vinci, artista da companhia Clara Della Guardia.

\section{Ilustração Paulista, número 62, 23/03/1912, ano II}

17.2. Notícias

\subsection{Teatros}

O Polytheama continuava em alta, agora com o sucesso das Rodrigues, acrobatas; o Trio Sola, bailarinos espanhóis; além de Le pantomime des chien dressés, e "o cachorro que fala de verdade".

\section{Ilustração Paulista, número $63,30 / 03 / 1912$, ano II}

\subsection{Notícias}

17.2.1. A coluna destaca o sucesso do teatro Casino e do Polytheama.

"No Polytheama, atualmente encontra-se de tudo: chanteuses, gommeuses e sem gomma, à voix, a diction, excentriqueset cominques, bailarinas espanholas, machiettistas, duettistas e cançonetistas italianas e internacionais, equilibristas, ilusionistas e Goytakysis com o seu célebre cão que fala."

\section{Ilustração Paulista, número 65, 20/04/1912, ano II}

\subsection{Notícias}

17.2.1. Pelos teatros 
Destaque para o sucesso no Polytheama e Casino.

17.3. Crítica Teatral

17.3.1. Teatro Municipal

O artigo, assinado por Manuel, trata da função do Teatro Municipal.

17. Ilustração Paulista, número 66, 27/04/1912, ano II

17.2. Notícias

17.2.1. Pelos Teatros

Novamente, o tema da seção é o sucesso dos espetáculos no Polytheama.

17. Ilustração Paulista, número 69, 18/05/1912, ano II

17.2. Notícias

17.2.1. Pelos Teatros

Os teatros Casino e Polytheama continuavam com êxito.

17. Ilustração Paulista, número 70, 25/05/1912, ano II

17.2. Notícias

17.2.1. Pelos teatros

Registra-se que depois que o Polytheama adotou o "novo sistema de espetáculos do gênero livre" sempre tem sucesso. O mesmo ocorria com o Casino.

17. Ilustração Paulista, número 71, 06/06/1912, ano II

17.2. Notícias

17.2.1. Pelos Teatros

Fazem sucesso no Casino e no Polytheama os espetáculos de gênero livre.

17. Ilustração Paulista, número 72 13/06/1912, ano II

17.2. Notícias

17.2.1. Pelos teatros

Elogios aos atores da Companhia Vitale, em cartaz no Polytheama. No São José trabalhava a Companhia Gattini-Angelini.

17. Ilustração Paulista, número 73, 20/06/1912, ano II

17.2. Notícias

17.2.1. Pelos teatros 
Estréia da Companhia Lírica italiana do empresário R. Mário \& Companhia, com Aída, de Verdi, no São José.

17. Ilustração Paulista, número 74, 27/06/1912, ano II

17.2. Notícias

17.2.1. Pelos teatros

Faz sucesso no São José a Companhia de Roberto Mário.

17. Ilustração Paulista, número $75,13 / 07 / 1912$, ano II

17.2. Notícias

17.2.1. Pelos teatros

Despedida da companhia de Roberto Mário. Estréia da companhia de operetas do empresário Lahoz, com a Princesa dos Dólares.

17. Ilustração Paulista, número 76, 20/07/1912, ano II

17.2. Notícias

17.2.1. Pelos teatros

Sucesso com a companhia de Ernesto Lahoz.

17. Ilustração Paulista, número 78, 03/08/1912, ano II

17.2. Notícias

17.2.1. Pelos teatros

Os teatros São José, Casino e Polytheama continuam com estréias e casa cheia.

17. Ilustração Paulista, número $79,10 / 08 / 1912$, ano II

17.2. Notícias

17.2.1. Pelos Teatros

A Companhia Lahoz continua no Teatro São José. Enquanto, o Casino prometia de 20 a 50 estréias, assim como o Polytheama.

17. Ilustração Paulista, número 81, 24/08/1912, ano II

17.2. Notícias

17.2.1. Pelos teatros

No São José, ocorreu uma festa em homenagem ao ator Pirracini, da Companhia Lahoz. A peça escolhida foi $O$ Conde de Luxemburgo. 


\section{Ilustração Paulista, número 82, 01/02/1913}

\subsection{Notícias}

\subsubsection{Teatros e Palcos}

No São José, trabalhava a Companhia Italiana Rotoli- Billoro. Os números de café-concerto atraíam numeroso público ao Polytheama. Destaque para a inauguração do Palace Theatre na Av. Brigadeiro Luís Antônio, com a Companhia Juvenil Italiana, encenando A Casta Suzanna. No Variedades fazia sucesso a revista Já te Pintei.

\section{Ilustração Paulista, número 83, 08/02/1913}

\subsection{Notícias}

17.2.1. Teatros e Palcos

Destaque para a estréia da Companhia Juvenil Italiana representando a Viúva Alegre, no Palace Theatre. No Variedades, é a vez da revista $O$ chegadinho conquistar o público.

\section{Ilustração Paulista, número $84,15 / 02 / 1913$}

\subsection{Notícias}

\subsubsection{Teatros e Palcos}

A transformista Fátima Miris trabalhava no São José. No Palace Theatre fazia sucesso a Companhia Juvenil Italiana, representando Babel Revista, de João Phoca.

\section{Ilustração Paulista, número $85,22 / 02 / 1913$}

\subsection{Notícias}

\subsubsection{Teatros e Salões}

A Companhia Lahoz representando Eva, Manobras do outono e O Camponês Alegre fazia um enorme sucesso no São José. O teatro Variedades trabalhava com os espetáculos por sessões.

\section{Ilustração Paulista}

Os números abaixo relacionados não apresentam informações sobre teatro:

número III, 05/11/1910, ano I

número $\mathrm{VI}, 26 / 11 / 1910$, ano I

número VII, 03/12/1910, ano I

número VIII, 23/02/1911, ano I

número IX, 02/03/1911, ano I

número $\mathrm{X}, 09 / 03 / 1911$, ano I 
18. Íris, número 1, 11/1905, volume I

Acervo: IEB

18.3. Crítica Teatral

18.3.1. LEAL, Arlindo Nacionalização do teatro.

Ensaio de Arlindo Leal abordando a importância de um país ter um teatro que represente a realidade de seu povo. (pp. 19-21)

18. Íris, não há indicação do mês da publicação, 1905, volume I

18.3. Crítica Teatral

18.3.1. LEAL, Arlindo. O realismo no teatro.

Ensaio acerca do realismo no teatro, proposto por Zola. (pp.86-89)

18. Íris, não há indicação do mês da publicação, 1906, volume I

18.3. Crítica Teatral

18.3.1. LEAL, Arlindo. Teatro Nacional.

Nesse artigo, Arlindo Leal clama pela valorização do teatro nacional. (pp.148-150)

18. Íris, não há indicação do mês da publicação, 1906, volume I

18.2. Notícias

18.2.1. Lançamento de Arco-Iris, chromos e fantasias, de Arlindo Leal. Segundo Coelho Neto, a obra "representa, nestes últimos tempos, em nosso meio, a mais bela e a mais promissora estréia literária". (pp.226-228)

18.2.2. Lançamento de Hino ao Sol, de Arlindo Leal. (pp.226-228)

18.3. Crítica Teatral

18.3.1. LEAL, Arlindo. Teatro Nacional.

$O$ ensaio critica as peças do gênero revista, que se utilizam, segundo o autor, de frases de baixo calão, trocadilhos chulos e pornografia. (pp. 192-195)

\section{8. Íris, não há indicação do mês da publicação, 1906, volume I}

18.3. Crítica Teatral

18.3.1. LEAL, Arlindo. Como eu entendo a crítica.

Arlindo Leal comenta sobre o papel do crítico, e o que deve ou não ser levado em consideração na hora de escrever uma crítica sobre determinada obra. (pp.254-256) 


\section{8. Íris, não há indicação do mês da publicação, 1906, volume II}

\subsection{Crítica Teatral}

18.3.1. MELLO, Vieira. Em vez de teatro, escolas.

O artigo do Dr. Vieira de Mello critica a construção de um grande teatro em São Paulo, cujo dinheiro poderia ser destinado a escolas. (pp.56-58)

18. Íris, não há indicação do mês da publicação, 1906, volume II

18.1. Peças de teatro, homenagens à classe teatral, escritos diversos de autores consagrados 18.1.1. LEAL, Arlindo. Hino ao Sol.

A peça, classificada como fantasia, faz um louvor à Arte, tendo como personagens: Erato, deusa da poesia, e Euterpe, deusa da música. (pp.177 a 182)

\section{8. Íris, não há indicação do mês da publicação, 1906, volume II}

18.1. Peças de teatro, homenagens à classe teatral, escritos diversos de autores consagrados 18.1.1. ALGUER. O Ano velho e o Ano Novo.

Pequena peça, classificada como diálogo simbólico. (pp.237-241)

\section{8. Íris, não há indicação do mês da publicação, 1907, volume III}

18.1. Peças de teatro, homenagens à classe teatral, escritos diversos de autores consagrados 18.1.1. Os Magos (Pastoral para o dia de Reis), tradução de Álvaro Guerra, do Ami du Clergé, de Paris. (pp.36 a 44)

\section{Klaxon}

Acervo: IEB

Os números correspondentes aos meses de maio a dezembro de 1922 não apresentam artigos sobre teatro.

Número 1 (15/05/1922) ao número 8 (12/1922), ano I.

\section{O Monóculo, número 1, 12/06/1915, ano I}

Acervo: IEB

\subsection{Notícias}

20.2.1. A empresa Walter Mocchi, concessionária do Teatro Colon, de Buenos Aires e do Município do Rio de Janeiro, pretendia trazer a São Paulo a Companhia de Tita Ruffo. 


\subsubsection{Os Deuses de Casaca}

"Para uma récita a realizar-se brevemente no Rio, em benefício da Sociedade dos Homens de Letras, vai ser representada a peça de Machado de Assis, intitulada Os Deuses de Casaca. A peça já entrou em ensaios, tomando parte nela os atores Coelho Neto, Goulart de Andrade, Oscar Lopes, Luiz Edmund, Bastos Tigre, etc".

Destaque para a trupe Arruda, que trabalhava no teatro Rink

\section{O Monóculo, número 2, 14/07/1915, ano I}

20.2. Notícias.

20.2.1. Despedida do trio Phoca- Abigail- Moreira

\section{A Novella Semanal, número $4,23 / 05 / 1921$, ano I}

Acervo: IEB

21.3. Crítica Teatral

21.3.1. Suplemento. Um novelista brasileiro do século XVIII.

Artigo sobre Antonio José, sua vida e sua obra como "teatrista" e novelista. (p.70)

\section{A Novella Semanal, número $5,28 / 05 / 1921$, ano I}

\subsection{Crítica Teatral}

21.3.1. Suplemento. Psicologia do teatro.

Artigo de um estudo de Henry Bidou. (pp.86-87)

\section{A Novella Semanal, número 11, 09/07/1921, ano I}

\subsection{Crítica Teatral}

21.3.1. Racine em café-concerto.

Relato de uma aventura em Londres, com a obra de Racine. No meio da representação da revista Londres, Paris e Nova York, o diretor resolveu entremear a peça com o terceiro ato de Andrômaca. (p.184)

\section{A Novella Semanal}

Não há informações sobre teatro nos números a seguir:

número 1, 02/05/1921, ano I

número 8, 18/06/1921, ano I

número $15,06 / 08 / 1921$, ano I 


\section{O Palco llustrado, número 1, junho de 1908}

Acervo: Arquivo do Estado de São Paulo

22.2. Notícias

22.2.1. No momento, trabalhava no Santana a Companhia Vitale. Destaque para Giselda, Morosoni e Inês Imbimbo; entre os homens, o cômico Ítalo Bertini. Em julho, estrearia, nesse teatro, a atriz Tina di Lorenzo, a "Rainha da Arte Dramática", sob a direção de Luigi Carini. A coluna traz o repertório que seria encenado pela atriz.

\section{Papel e Tinta, número 1, 31/05/1920, ano I}

Acervo: IEB

23.4. Entrevistas, enquetes

23.4.1. Nossos artistas na intimidade. (pp.31-32)

Entrevista com a atriz Itália Fausta

23. Papel e Tinta, número 3, julho/1920, ano I

23.4. Entrevistas, enquetes

23.4.1. Nossos artistas na intimidade.

Entrevista com o ator Leopoldo Fróes.

\section{A Paulicéia Moderna, número XXIII, 09/08/1919, ano III}

Acervo: IEB

24.2. Notícias.

24.2.1. Notícias dos espetáculos em cartaz na cidade. Destaque para a representação de $O$ Triptico, de Puccini.

\section{O Pirralho, número 01, 12/08/1911, ano I}

Acervo: Biblioteca Mário de Andrade e Biblioteca Nacional 25.2. Notícias

25.2.1. De Camarote

Maneco, o crítico, comenta os espetáculos em cartaz na cidade.

Polytheama 


\section{Estréia da Companhia Galhardo}

São José

"No São José a trágica companhia do ator Alves da Silva vai dando o Conde de Monte Cristo, o Processo Dreylus, A Largatixa (sic), e outras criações patéticas do teatro português." (p. 8)

\section{O Pirralho, número $02,19 / 08 / 1911$, ano I}

\subsection{Notícias}

25.2.1. De Camarote

No Polytheama faz sucesso a Companhia Galhardo, com A Divorciada e O Conde de Monte Cristo

\section{O Pirralho, número $03,26 / 08 / 1911$, ano I}

25.2. Notícias

\subsubsection{De Camarote}

Elogios à Companhia Galhardo, em cartaz no Polytheama, e também à atriz Cremilda desta companhia.

No Sant'Anna estreou a companhia lírica infantil italiana.

No Casino faz sucesso uma companhia francesa.

Sátira sobre a estréia do Teatro Municipal. O Pirralho informa que o teatro será inaugurado com um impagável poema tragi - cômico, de colaboração diversa, intitulado La Figlia Del caramurú.

"La Figlia Del Caramurú é uma obra de mocidade de dois membros da comissão do Municipal em companhia do Dr. J. J. e de mais um italianinho que verteu a salada dantescamente." (p. 11)

\section{O Pirralho, número 04, 02/09/1911, ano I}

25.2. Notícias

25.2.1. De Camarote

Sant'Anna

Houve protestos contra o trabalho de menores da companhia infantil em cartaz neste teatro, mas mesmo assim as apresentações tiveram êxito.

\section{Polytheama}

Estréia da Companhia portuguesa, na qual trabalha Palmyra Bastos, com a peça Amor de Príncipe.

\section{Casino}

Sucesso neste music-hall com a companhia francesa La Camargo.

A Companhia Camerata de operetas está vindo a São Paulo reabrir o São José. (p. 6) 


\section{O Pirralho, número 05, 09/09/1911, ano I}

\subsection{Notícias}

25.2.1. De Camarote

Sucesso de Palmyra Bastos no Polytheama com as operetas Amor de Príncipe, Sangue Vienense e outras. (p. 10)

\section{O Pirralho, número $7,23 / 09 / 1911$, ano I}

25.2. Notícias

25.2.1. De Camarote

Polytheama

Estréia da companhia Maresca.

São José

Sob a direção do cômico Gravina, estreou uma companhia italiana de operetas.

Santana

Chaby apresentou monólogos e João Phoca recitou uma conferência.

Municipal

Sucesso da ópera Tristão e Isolda.

Coluna assinada por Cícero Sylvestre.

\section{O Pirralho, número 08, 30/09/1911, ano I}

\subsection{Notícias}

25.2.1. De Camarote. Cícero Sylvestre.

A Companhia Titta Ruffo obteve sucesso com Rigoleto e O Barbeiro de Sevilha, apesar do fracasso de Tristão e Isolda, do "péssimo desempenho" de Manon Lescaut e Madame Butterfly. Polytheama

A Companhia Maresca, apesar de algumas críticas, faz sucesso com o seu repertório.

\section{Santana}

Faz enorme sucesso a troupe Chaby - Phoca - Collaço. (pp. 11-12)

\section{O Pirralho, número 09, 07/10/1911, ano I}

\subsection{Notícias}

25.2.1. Teatros. Cícero Sylvestre.

Municipal

Despediu-se a Companha Lírica italiana com O Barbeiro de Sevilha.

Polytheama 
Continuava de "vento em popa" a Companhia Maresca, apesar dos insucessos com a representação de Granadeiros e Sonhos de Valsa.

São José

"Neste teatro a Companhia Camerata vai cavando a vida". (p. 7)

\section{O Pirralho, número $13,04 / 11 / 1911$, ano I}

\subsection{Notícias}

25.2.1. Teatros. Cícero Sylvestre.

"Em matéria de teatro estamos mal. No Sant'Anna uma troupe heterogênea e cosmopolita procura modestamente ganhar a vida representando retalhos de operetas."

Municipal

Segundo o colunista, esse teatro está se transformando em casa de chá. (p. 10)

\section{O Pirralho, número 14, 11/11/1911, ano I}

25.2. Notícias

25.2.1. Teatros. Cícero Sylvestre.

\section{Polytheama}

Continua a Companhia Renzi - Gabrielle.

Santana

Uma trupe luso-hispano brasileira explora o teatro por sessões.

Municipal

Segundo o colunista, esse teatro continua fechado como casa de espetáculos, e funciona somente como casa de chá. (p. 10)

\section{O Pirralho, número $16,25 / 11 / 1911$, ano I}

\subsection{Notícias}

25.2.1. Teatros. Cícero Sylvestre.

"Tudo quanto dissemos na crônica passada poderíamos perfeitamente repetir na de hoje. Nada de novo ocorreu. Continua tudo na mesma." (p. 9)

\section{O Pirralho, número $17,02 / 12 / 1911$, ano I}

25.2. Notícias

25.2.1. Teatros. Cícero Sylvestre.

Segundo o colunista, "O programa para variar é o mesmo." (p. 11) 


\section{O Pirralho, número $18,09 / 12 / 1911$, ano I}

\subsection{Notícias}

25.2.1. Teatros.

Faz sucesso no Santana a representação de Os dois nenéns, com o ator Arruda. (p. 14)

\section{O Pirralho, número 19, 16/12/1911, ano I}

\subsection{Notícias}

\subsubsection{Teatros. Cícero Sylvestre.}

A coluna registra uma melhora na cena teatral com a saída da companhia Renzi-Gabrielli, e a chegada da Companhia Vitale; apesar de essa ter "desrespeitado" o público, segundo o crítico, "dizendo obscenidades em cena, enxertando tolices de todos os tamanhos", há dois anos.

O Santana segue com o sucesso de Os dois nenéns. (p. 10)

\section{O Pirralho, número 20, 23/12/1911, ano I}

\subsection{Notícias}

\subsubsection{Autêntico}

No Polytheama, a Companhia italiana representa Quo Vadis. (p. 6)

Pelos Teatros. Cícero Silvestre.

"Nada de novo temos a noticiar".

O artigo faz uma crítica à exploração do teatro Municipal pelo sindicato que resolveu trazer Companhias líricas. (p. 13)

\section{O Pirralho, número 21, 3/12/1911, ano I}

\subsection{Notícias}

\subsubsection{Pelos Teatros}

"Nada absolutamente de novo em matéria de espetáculos."

No Polytheama, a Companhia Vitale continuava fazendo sucesso com A Casta Suzana, Amor de Zíngaro, Manobras de Outono, O Conde de Luxemburgo e Viúva Alegre.

No Santana, o sucesso fica por conta de A Grande Avenida.

\section{O Pirralho, número 23, 13/01/1912, ano II}

\subsection{Notícias}

25.2.1. Pelos Teatros

No Polytheama continua a Companhia Vitale. (p. 6) 


\section{O Pirralho, número 24, 20/01/1912, ano II}

\subsection{Notícias}

\subsubsection{Pelos Teatros}

Enquanto o Casino abriga os bailes carnavalescos, no Variedades faz sucesso $A$ mala de João Cândido. (p. 12)

\section{O Pirralho, número $25,27 / 01 / 1912$, ano II}

25.1. Peças de teatro, homenagens à classe teatral, escritos diversos de autores consagrados

25.1.1. A rinha no Cenáculo. Cena íntima de Henry Bel. (p.09)

25.2. Notícias

25.2.1. Pelos Teatros

A coluna faz elogios à Companhia Vitale e à Companhia Marchetti. (p. 10)

\section{O Pirralho, número $27,10 / 02 / 1912$, ano II}

\subsection{Notícias}

25.2.1. Pelos Teatros

Destaque para o sucesso da Companhia Marchetti no teatro São José. No Polytheama estréia a trupe South American Tour. (p. 16)

\section{O Pirralho, número 28, 17/02/1912, ano II}

25.2. Notícias

\subsubsection{Pelos Teatros}

A sessão, novamente, elogia a Companhia Marchetti, em cartaz no São José. Elogia também a trupe do Polytheama e os artistas do Casino. (p. 14)

\section{O Pirralho, número 29, 24/02/1912, ano II}

\subsection{Notícias}

25.2.1. Pelos Teatros

A sessão não traz novidades, só repete o que foi dito na anterior. (p. 10)

\section{O Pirralho, número $30,02 / 03 / 1912$, ano II}

\subsection{Notícias}

25.2.1. Pelos Teatros

A apresentação de Vida de Boêmia não esteve à altura da Companhia Marchetti. (p. 14) 


\title{
25. O Pirralho, número 31, 09/03/1912, ano II
}

\author{
25.2. Notícias
}

25.2.1. Pelos Teatros

Despedida da Companhia Marchetti. Destaque para a estréia da Companhia de Cristiano de Souza com a comédia Francillon, de Dumas Filho.

O Polytheama continua com a troupe South American Tour. (p. 8)

\section{O Pirralho, número $32,16 / 03 / 1912$, ano II}

\subsection{Notícias}

25.2.1. Pelos Teatros

Após a representação de Francillon, a Companhia Cristiano de Souza apresentou A Dama das Camélias.

"Esta peça que é um produto do ultra - romantismo, se bem que não condiga com os moldes do teatro contemporâneo, conta ainda hoje grande quantidade de admiradores." Mas a peça não correspondeu às expectativas, devido à interpretação de Margarida Gautier, feita por Lucília Peres. (p. 13)

\section{O Pirralho, número $33,23 / 03 / 1912$, ano II}

\subsection{Notícias}

\subsubsection{Pelos Teatros}

A Companhia Cristiano de Souza não está tendo muito público: "Afinal, isto não admira: o nosso público decididamente detesta a arte dramática como já o demonstrou muitas e muitas vezes". Um destaque da Companhia é a apresentação do "célebre vaudeville alemão em três atos $O$ Rato Azul'.

O Polytheama e o Casino continuam desfrutando do sucesso. (p. 10)

\section{O Pirralho, número 34, 30/03/1912, ano II}

\subsection{Notícias}

\subsubsection{Pelos Teatros}

A artista Adelaide Coutinho da Companhia Cristiano de Souza atuou na peça $A$ Morgadinha de Val Flor, de Pinheiro Chagas. A Companhia despediu-se de São Paulo com a peça de Jean Aicard, Papá Lebonnard.

"Infelizmente esta companhia não foi apreciada, pelo nosso público, que à mais bela peça do teatro dramático prefere a estafante Viúva Alegre."

Não param as estréias sempre muito aplaudidas no Casino e no Polytheama. (p. 5) 


\section{O Pirralho, número $35,06 / 04 / 1912$, ano II}

\subsection{Notícias}

25.2.1. Pelos Teatros

Estréia no São José a Companhia Juvenil Italiana de Óperas e Operetas, com a peça O Conde de Luxemburgo. (p. 7)

\section{O Pirralho, número $36,13 / 04 / 1912$, ano II}

25.2. Notícias

25.2.1. Pelos Teatros

Um público sempre numeroso acompanha as estréias do Polytheama, Casino e São José, este último com a Companhia Juvenil Italiana. (sem $n$. ำ de páginas)

\section{O Pirralho, número $37,20 / 04 / 1912$, ano II}

25.2. Notícias

25.2.1. Pelos Teatros

A Companhia juvenil italiana não obteve êxito com a representação da Viúva Alegre.

\section{O Pirralho, número 38, 27/04/1912, ano II}

\subsection{Notícias}

25.2.1. Pelos Teatros

Foi satisfatória a representação de Amor de Príncipe, pela Companhia Città di Roma. No Polytheama, a troupe South American Tour disputou a atenção com a Companhia Arayama de equilibristas japoneses.

\section{O Pirralho, número $39,04 / 05 / 1912$, ano II}

25.2. Notícias

25.2.1. Pelos Teatros

O São José continua com a companhia Città di Roma, que levou à cena a ópera Sonnambula, de Bellini.

\section{O Pirralho, número $40,11 / 05 / 1912$, ano II}

\subsection{Notícias}

25.2.1. Pelos Teatros

Foi para o Colombo a companhia Città di Roma. No Variedades é bastante aplaudida a companhia dirigida pelo ator Taveira. 


\section{O Pirralho, número $41,18 / 05 / 1912$, ano II}

\subsection{Notícias}

\subsubsection{Pelos Teatros}

No Variedades, a Companhia do ator Taveira obteve sucesso com a revista Do Inferno a São Paulo, "arranjo do ator Arruda, e do acadêmico de direito Francisco de Camargo Penteado".

\section{O Pirralho, número $42,25 / 05 / 1912$, ano II}

\subsection{Notícias}

\subsubsection{Pelos Teatros}

O artigo elogia a empresa do Polytheama, responsável pelo sucesso desse teatro.

No Casino, Fregolino apresenta suas comédias "mais ou menos elétricas".

\section{O Pirralho, número $43,01 / 06 /$ de 1912 , ano II}

\subsection{Notícias}

25.2.1. Pelos Teatros

O acrobatas musicais Whinterley e o malabarista cômico José Chas estréiam no Polytheama. No Casino, apresentam-se Los Alpinos, e no Variedades, o ator Taveira e seus companheiros.

\section{O Pirralho, número $45,15 / 06 / 1912$, ano II}

\subsection{Notícias}

25.2.1. Pelos Teatros

Os artistas do Polytheama e Casino continuam com grande sucesso, assim como a Companhia de revistas do ator Taveira.

\section{O Pirralho, número 46, 22/06/1912, ano II}

\subsection{Notícias}

25.2.1. Pelos Teatros

A coluna tece elogios e críticas à atuação dos atores-cantores da companhia lírica que trabalhava no teatro São José.

\section{O Pirralho, número $47,29 / 06 / 1912$, ano II}

\subsection{Notícias}

25.2.1. Pelos Teatros 
Os artistas da Companhia lírica, do São José, estão muito satisfeitos com o público de São Paulo. Quanto aos espetáculos da companhia do Sr. Roberto Mário, esses foram desempenhados razoavelmente.

\section{O Pirralho, número $48,06 / 07 / 1912$, ano II}

\subsection{Notícias}

25.2.1. Pelos Teatros

Estréia da Companhia de Operetas do maestro Ernesto Lahoz com A Princesa dos Dólares, de Leo Fall, no São José. No Polytheama o sucesso continua com os ciclistas cômicos e os acrobatas musicais. A estréia, no Casino, se deu com os excêntricos musicais Lima y Stise.

\section{O Pirralho, número 49, 13/07/1912, ano II}

25.2. Notícias

25.2.1. Pelos Teatros

A companhia Lahoz não agradou muito com a representação de $A$ Casta Suzanna.

\section{O Pirralho, número 50, 20/07/1912, ano II}

\subsection{Notícias}

25.2.1. Pelos Teatros

O artigo comenta a atuação dos atores da Companhia francesa que estreou no Municipal, com La grife, de Henry Bernstein. No São José, a opereta Eva, de Franz Lehar, alcançou mais um sucesso com a Companhia Lahoz.

\section{O Pirralho, número 51, 27/07/1912, ano II}

25.2. Notícias

25.2.1. Pelos Teatros

Comentários sobre a interpretação que da peça La Massiére, de Jules Lemaitre.

\section{O Pirralho, número 52, 03/08/1912, ano II}

\subsection{Notícias}

24.2.1. Pelos Teatros

A Companhia Lírica Italiana La Teatral estréia, no Municipal, com a "velha e popular ópera de Verdi, Rigolleto". 


\section{O Pirralho, número 53,10/08/1912, ano II}

\subsection{Notícias}

25.2.1. Pelos Teatros

Estréia no São José a opereta de Franz Lehar $A$ filha do bandido. O desempenho, segundo comentários do colunista, não foi dos melhores.

\section{O Pirralho, número 54, 17/08/1912, ano II}

25.1. Peças de teatro, homenagens à classe teatral, escritos diversos de autores consagrados 25.2.1. Ressurreição de Nicarágua. "Vaudeville, d'aprés a novela da bella Otero, por Chico Biscoito".

25.2. Notícias

25.2.1. Pelos Teatros

Estréia no Municipal a Companhia Dramática da artista Clara Della Guardia, com a Rosmunda, de Sam Benelli.

\section{O Pirralho, número 55, 24/08/1912, ano II}

25.1. Peças de teatro, homenagens à classe teatral, escritos diversos de autores consagrados 25.1.1. Continuação do vaudeville Ressurreição de Nicarágua.

\subsection{Notícias}

25.2.1. Pelos Teatros

O colunista comenta que o público prefere o cinematógrafo e as "estafantes" operetas Viúva Alegre e A Casta Suzana aos espetáculos de caráter literário. O teatro Municipal, conforme o colunista, só não ficava vazio, devido às boas Companhias que ali trabalhavam. Ele refere-se à artista Clara Della Guardia: "Na Dama das Camélias ela compôs muito bem o tipo daquela mundana apaixonada e chorosa."

\section{O Pirralho, número 56, 31/08/1912, ano II}

25.2. Notícias

25.2.1. Pelos Teatros

O São José presencia o sucesso das apresentações de $A$ filha do bandido e $O$ marido das três mulheres.

\section{O Pirralho, número 57, 07/09/1912, ano II}

\subsection{Notícias}

25.2.1. Pelos Teatros 
Despedida da companhia de operetas do maestro Lahoz.

25. O Pirralho, número 58, 14/09/1912, ano II

25.2. Notícias

25.2.1. Pelos Teatros

No Municipal, estréia a Companhia Dramática italiana Ermete Novelli, com a peça de Jean Aicard, Papá Lebonnard.

\section{O Pirralho, número 59, 21/09/1912, ano II}

\subsection{Notícias}

25.2.1. Pelos Teatros

Destaque para a oportunidade de ver Ermete Novelli no papel de Luiz XI. O artigo elogia a atuação do ator.

\section{O Pirralho, número $60,05 / 10 / 1912$, ano II}

\subsection{Notícias}

25.2.1. Pelos Teatros

"O velho teatro da rua de S. João continua a apanhar boas enchentes, pois o nosso público não se cansa de apreciar os artistas da South American Tour". O colunista refere-se ao Polytheama.

\section{O Pirralho, número $61,12 / 10 / 1912$, ano II}

\subsection{Notícias}

\subsubsection{Pelos Teatros}

Estréia da companhia do maestro Costa Júnior com a opereta Casta Suzanna.

25.5. Fotos

25.5.1. Foto de Maria Ivanisi, na Viúva Alegre, e Jeanoe Morini, no Capitão Fracassa, acompanhada de nota sobre a estréia da Companhia Italiana de Ópera Cômica, SconamiglioCaramba.

\section{O Pirralho, número $62,19 / 10 / 1912$, ano II}

25.2. Notícias

25.2.1. Pelos Teatros

Após A Casta Suzanna, a Companhia de Costa Júnior, leva à cena Eva e o Conde de Luxemburgo. 
25. O Pirralho, número $63,26 / 10 / 1912$, ano II

25.2. Notícias

25.2.1. Pelos Teatros

A companhia que trabalha no teatro São José vai de "vento em popa", com as peças $A$ princesa dos Dólares e Viúva Alegre.

25. O Pirralho, número $64,02 / 11 / 1912$, ano II

25.2. Notícias

25.2.1. Pelos Teatros

Anúncio de estréia da Companhia Italiana de Óperas Cômicas Sconamiglio-Caramba, no São José.

25. O Pirralho, número $65,09 / 11 / 1912$, ano II

25.2. Notícias

25.2.1. De camarote

Estréia da companhia Sconamiglio-Caramba, com O Cigano Barão, de Strauss.

25. O Pirralho, número $66,16 / 11 / 1912$, ano II

25.2. Notícias

25.2.1. De camarote

A companhia que trabalha no São José vem conquistando a simpatia do público, mas "dado o renome da companhia, esperávamos coisa melhor". No Variedades, a Companhia de Cristiano de Souza faz sucesso.

25. O Pirralho, número $67,23 / 11 / 1912$, ano II

25.2. Notícias

25.2.1. De camarote

No São José, o sucesso continua com a Companhia Sconamiglio-Caramba.

25. O Pirralho, número $68,30 / 11 / 1912$, ano II

25.2. Notícias

25.2.1. De camarote

No Polytheama, destaca-se a cantora e bailarina espanhola Mercedes Alfonso e a cançonetista italiana Gina Vandéa. 
25. O Pirralho, número $69,07 / 12 / 1912$, ano II

25.2. Notícias

25.2.1. De camarote

No São José, continua o êxito da companhia Sconamiglio-Caramba.

24. O Pirralho, número $70,14 / 12 / 1912$, ano II

24.2. Notícias

24.2.1. De camarote

Agora no Colombo, a Companhia Sconamiglio-Caramba faz três récitas a preços populares.

25. O Pirralho, número $71,21 / 12 / 1912$, ano II

25.2. Notícias

25.2.1. De camarote

São José, Polytheama e Casino continuam com os mesmos sucessos.

25. O Pirralho, número $72,28 / 12 / 1912$, ano II

25.2. Notícias

25.2.1. De camarote

Despedida da Companhia Sconamiglio-Caramba. Destaque para a estréia da Companhia Lírica Rotoli-Biloro, com a ópera Tosca.

25. O Pirralho, número $73,04 / 01 / 1913$, ano III

25.2. Notícias

25.2.1. De camarote

Comentários acerca da atuação dos artistas da Companhia Lírica Rotoli-Biloro.

25. O Pirralho, número $74,18 / 01 / 1913$, ano III

25.2. Notícias

25.2.1. De camarote

Continua com sucesso a companhia Rotoli-Biloro, assim como os artistas do Polytheama e do Colombo.

25. O Pirralho, número $75,25 / 01 / 913$, ano III

25.2. Notícias

25.2.1. De camarote 
Nenhuma novidade. A companhia Rotoli-Biloro continua fazendo sucesso. Animados e lotados continuam o Polytheama e o Casino.

\section{O Pirralho, número 76, 01/02/1913, ano III}

25.2. Notícias

252.1. De camarote

Encerramento da temporada da Companhia Rotoli-Biloro, com a ópera Íris. É inaugurado o Palace Theatre com a Companhia Juvenil italiana dos irmão Billand, com a peça $A$ Casta Suzanna.

253. CríticaTeatral

25.3.1. Arte Dramática, da sessão Os Ratos.

$\mathrm{O}$ artigo constitui uma crítica e, principalmente, uma forte sátira à falta de dramaturgos nacionais.

\section{O Pirralho, número $77,08 / 02 / 1913$, ano III}

\subsection{Notícias}

25.2.1. De camarote

Estréia da transformista Fátima Miris, no São José. No Palace Theatre, a Companhia dirigida pelos irmãos Billand faz muito sucesso. Muito se deve à atuação dos atores da companhia, segundo o crítico.

25.3.1. Babel Revista

Comentários sobre a Companhia Juvenil que trabalhava no Palace Theatre, e a montagem de Babel Revista, de João Phoca.

\section{O Pirralho, número $78,15 / 02 / 1913$, ano III}

25.2. Notícias

25.2.1. De camarote

Babel Revista conseguiu um enorme sucesso.

\section{O Pirralho, número $79,22 / 02 / 1913$, ano III}

\subsection{Notícias}

25.2.1. De camarote

Estréia da troupe de Ernesto Lahoz, com a opereta Eva, no São José.

25.3. Crítica Teatral 
25.3.1 Artigo sobre a conferência literária de Coelho Neto, após a representação de Pastoral, de sua autoria.

25. O Pirralho, número $80,01 / 03 / 1913$, ano III

25.2. Notícias

25.2.1. De camarote

A Companhia Lahoz, com as representações de Amor de Príncipe e O Camponês Alegre conquistou sucesso.

25. O Pirralho, número $81,08 / 03 / 1913$, ano III

24.2. Notícias

24.2.1. De camarote

Apresentação da opereta Jockey- Club com a companhia Lahoz, no São José. A nota comenta a atuação dos atores e da orquestra.

\section{O Pirralho, número $82,15 / 03 / 1913$, ano III}

25.2. Notícias

25.2.1. De camarote

Despedida da companhia Lahoz. No Variedades, a Companhia de Pablo Lopez obteve muitos aplausos com as representações de O Barbeiro de Sevilha e La Tempranica de Granada.

\section{O Pirralho, número $83,22 / 03 / 1913$, ano III}

25.2. Notícias

25.2.1. De camarote

Estréia da Companhia Italiana de Óperas bufas e Operetas do empresário Ettore Vitale.

25.2.2. Propaganda de lançamento do Almanaque Teatral Brasileiro, que se propõe a ser um resumo das estações teatrais de São Paulo, Rio de Janeiro, e outros estados brasileiros e estrangeiros.

\section{O Pirralho, número $84,29 / 03 / 1913$, ano III}

25.1. Peças de teatro, homenagens à classe teatral, escritos diversos de autores consagrados

25.1.1. Tragédia no Lar. Farsa em um ato. Pau d’água.

25.2. Notícias

25.2.1. De camarote 
Nota sobre a festa no Municipal e a representação de Pastoral, de Coelho Neto. Comentários sobre a estréia da Companhia do empresário Vitale, com a representação de Eva, de Franz Lehar.

25. O Pirralho, número $85,05 / 04 / 1913$, ano III

25.2. Notícias

25.2.1. De camarote

Comentários sobre as representações da opereta de Gilbert, La donna Moderna.

25. O Pirralho, número $86,12 / 04 / 1913$, ano III

25.2. Notícias

25.2.1. De camarote

A troupe Vitale, que trabalha no São José, vai indo regularmente com alguns artistas bons, outros nem tanto, segundo o colunista.

25. O Pirralho, número $87,19 / 04 / 1913$, ano III

25.2. Notícias

25.2.1. De camarote

A interpretação da troupe Vitale à opereta Bocaccio não correspondeu à expectativa do público.

25. O Pirralho, número $88,26 / 04 / 1913$, ano III

25.2. Notícias

25.2.1. De camarote

A Companhia Vitale não está correspondendo às expectativas do público, desta vez foi com $A$ Casta Suzana.

25. O Pirralho, número $89,03 / 05 / 1913$, ano III

25.2. Notícias

25.2.1. De camarote

Um pouco melhor foi a interpretação de O Caro Agostinho, de Leo Fall, pela Companhia Vitale.

25. O Pirralho, número $90,10 / 05 / 1913$, ano III

25.2. Notícias

25.2.1. De camarote 
A opereta Dona Juanita, de Suppé, foi levada à cena pela Companhia Vitale, e alcançou grande sucesso.

25. O Pirralho, número $91,17 / 05 / 1913$, ano III

25.2. Notícias.

25.2.1. De Camarote

Chega ao fim a temporada da Companhia Vitale.

\section{O Pirralho, número $92,24 / 05 / 1913$, ano III}

\subsection{Notícias}

25.2.1. De Camarote

O ator italiano Ermete Novelli estreou com a peça Pão Alheio, de Turgueniev.

De acordo com o texto, se não fosse a atuação de Novelli, nada teria de interessante na peça deste escritor russo.

25.3. Crítica Teatral

25.3.1. PRISCUS, Marcus. Coisas da rua.

O artigo elogia o artista Ermete Novelli, que estreou no São José.

\section{O Pirralho, número $93,31 / 05 / 1913$, ano III}

25.2 Notícias

25.2.1. De Camarote

As criações de Novelli continuam a encantar o público paulistano.

\section{O Pirralho, número $94,07 / 06 / 1913$, ano III}

25.2 Notícias

25.2.1. De Camarote

Estréia da companhia alemã Tuscher, com a peça Eva, "uma das operetas mais queridas do nosso público". No Palace Theatre, ocorre a apresentação da opereta Amores de Tricana, de Mário Monteiro, na festa da atriz Abigail Maia.

\section{O Pirralho, número $96,21 / 06 / 1913$, ano III}

25.2 Notícias

25.2.1. De Camarote

Foi apresentada, no São José, a opereta Sua Alteza Valsa, em homenagem pelo aniversário da subida do Kaiser da Alemanha ao trono. No Palace Theatre, estréia a companhia portuguesa, da 
qual fazem parte Adelina Branches e Alexandre de Azevedo. Os atores levaram à cena o vaudeville A menina do chocolate e Garoto de Lisboa.

\section{O Pirralho, número $97,28 / 06 / 1913$, ano III}

25.2 Notícias

\subsubsection{De Camarote}

A coluna se dedica a comentar sobre dois atores da Companhia Adelina Abranches: Alexandre de Azevedo e Luciano de Castro.

\subsection{Crítica Teatral}

\subsubsection{Adelina Abranches e J. A Lamego}

É um artigo comentando a atuação e sucesso da atriz nos espetáculos apresentados no Palace Theatre. Apesar do "público diminuto e indiferente à sua arte fina e sutil", que a faz passar despercebida, tendo que trabalhar por sessões, como nas companhias mambembes", informa 0 crítico.

\section{O Pirralho, número $98,05 / 07 / 1913$, ano III}

25.2 Notícias

\subsubsection{De Camarote}

Estréia da companhia de operetas do teatro Recreio, do Rio de Janeiro, com a opereta de costumes portugueses Amores de Tricana. No Palace Theatre, trabalha, no momento, a Companhia Nacional de Operetas, representando a revista Jocotó, e a opereta Gatinha Branca. A companhia Adelina Abranches encerrou sua temporada com a peça: A menina do chocolate. Destaque para a artista italiana Tina di Lorenzo, no Municipal. $O$ artigo elogia muito o desempenho dessa artista.

\section{O Pirralho, número 99, 12/07/1913, ano III}

\subsection{Notícias}

\subsubsection{De Camarote}

Realizada, no Municipal, a festa artística do cômico Armando Falconi, que trabalha com Tina de Lorenzi e Febo Mari. Despedida dessa companhia e estréia da companhia francesa do ator Félix Huguénet, com a comédia Papá, de De Flers e Caillavet.

\section{O Pirralho, número 100, 19/07/1913, ano III}

25.2 Notícias

25.2.1. De Camarote 
A platéia se deliciou com a companhia francesa, da qual faz parte 0 ator Félix Huguenet. As peças apresentadas, no São José, pela Companhia Portuguesa de Revistas e Operetas de José Loureiro alcançaram enorme sucesso.

\section{O Pirralho, número $101,26 / 07 / 1913$, ano III}

25.2 Notícias

25.2.1. De Camarote

O destaque da semana, no Polytheama, fica por conta de Sereja, duo Luzitano, e outros. No São José, estréia a Companhia Israelita de variedades, com as comédias Schutames, Depois do Casamento e Os dois Vagabundos.

25. O Pirralho, número 102, 02/08/1913, ano III

25.2 Notícias

25.2.1. De Camarote

Em breve, estréia da companhia Città di Milano.

25. O Pirralho, número 104, 16/08/1913, ano III 25.2 Notícias

25.2.1. De Camarote

No São José, faz muito sucesso a companhia Città di Milano. Coro, orquestra e artistas são responsáveis pelo sucesso.

25. O Pirralho, número $105,23 / 08 / 1913$, ano III

25.2 Notícias

25.2.1. De Camarote

"A companhia Città di Milano vai prosseguindo na série brilhante de sucessos."

25. O Pirralho, número 106, 30/08/1913, ano III

25.2 Notícias

25.2.1. De Camarote

Realização da quinta récita do Grêmio Dramático Santa Cecília, com as peças: Os dois surdos e Os crimes do Brandão.

25. O Pirralho, número $107,06 / 09 / 1913$, ano III

25.2 Notícias 
252.1. De Camarote

O Polytheama continua trazendo novidades a São Paulo, entre elas Jane Rinaldi, Maria Angelini, Renée Vincy, etc.

\section{O Pirralho, número 108,13/09/1913, ano III}

25.2 Notícias

25.2.1. De Camarote

O Polytheama continua fazendo sucesso como café-concerto. No São José, estréia a Companhia Portuguesa de Operetas Gomes \& Grijó.

\section{O Pirralho, número 109, 20/09/1913}

25.2 Notícias

25.2.1. De Camarote

Grêmio Dramático Santa Cecília

A agremiação levou à cena a comédia de Aristides Abranches: um homem político, que veio muito a calhar com a situação do país na época, conforme a revista.

\section{O Pirralho, número $110,27 / 09 / 1913$, ano III}

25.2 Notícias

25.2.1. De Camarote

No Polytheama, são sempre concorridos os espetáculos apresentados.

\section{O Pirralho, número $111,04 / 10 / 1913$, ano III}

25.2 Notícias

25.2.1. De Camarote

Segundo o colunista, o Polytheama parece ser o único a quem a crise não atinge nunca: "Ele é o antídoto da crise".

\section{O Pirralho, número $113,18 / 10 / 1913$, ano III}

25.2 Notícias

25.2.1. De Camarote

No Variedades, a Companhia Italiana de Giacomo Almirante tem agradado muito.

25. O Pirralho, número $114,25 / 10 / 1913$, ano III

25.2 Notícias 
25.2.1. De Camarote

Como não podia deixar de ser, o Polytheama continua com sucesso. O antigo Moulin Rouge, atual variedades, hospeda a Companhia Cômica Italiana Almirante.

25. O Pirralho, número $115,01 / 11 / 1913$, ano III

25.2 Notícias

25.2.1. De Camarote

Agora são os equilibristas cômicos, as cantoras "chics" e os acrobatas excêntricos que dão o tom no Polytheama.

25. O Pirralho, número $116,08 / 11 / 1913$, ano III

25.2 Notícias

25.2.1. De Camarote

No Variedades, a troupe Almirante tem sido muito aplaudida.

25. O Pirralho, número $117,15 / 11 / 1913$, ano III

25.2 Notícias

25.2.1. De Camarote

Quanto ao Polytheama, o colunista afirma: "Como sempre concorridíssimos os espetáculos deste querido e pop

25. O Pirralho, número 118, 22/11/1913, ano III

25.2 Notícias

25.2.1. De Camarote

As bailarinas, a cantora italiana Claretta de Lille, atiradores, etc. são os artistas que se apresentam no Polytheama.

25. O Pirralho, número $119,29 / 11 / 1913$, ano III

25.2 Notícias

25.2.1. De Camarote

No Polytheama, as estréias chegam a seis ou oito por semana.

25. O Pirralho, número $120,06 / 12 / 1913$, ano III

25.2 Notícias

25.2.1. De Camarote 
"Últimas noitadas do velho teatro"- Polytheama- pois será substituído pelo Casino Antarctica. No Palace Theatre, estréia a Companhia Sconamiglio-Caramba.

\section{O Pirralho, número 124, 03/01/1914, ano III}

25.2 Notícias

25.2.1. Teatros

Faz sucesso, no Palace Theatre, a Companhia Sconamiglio-Caramba.

\section{O Pirralho, número 125, 10/01/1914, ano III}

25.2 Notícias

25.2.1. De Camarote

O variado repertório e os bons elementos da companhia Caramba garantem a temporada de sucesso.

\section{O Pirralho, número 136, 28/03/1914, ano III}

25.2 Notícias

25.2.1. Grêmio Dramático Santa Cecília

Em virtude de um sarau promovido por este grupo, em benefício da escola paroquial, haverá a representação de duas comédias por estes "amadores dramáticos".

\section{O Pirralho, número 137, 04/04/1914, ano III}

25.2 Notícias

25.2.1. Festa do Grêmio de Santa Cecília, com a representando da comédia Os Supersticiosos

\section{O Pirralho, número 141, 02/05/1914, ano III}

\subsection{Notícias}

25.2.1. Teatros

São Paulo Futuro

A revista de Danton Vampré e João Felizardo, musicada por F. Lobo, tem feito enorme sucesso. Após essa montagem, espera-se a revista de costumes paulistas São Paulo em Fraldas, de Ricardo de Oliveira e música do maestrino Bentinho Cintra.

\section{O Pirralho, número 144, 23/05/1914, ano III}

25.1. Peças de teatro, homenagens à classe teatral, escritos diversos de autores consagrados 
25.1.1. Sitianópolis. Comédia curta que satiriza o governo. Os personagens são: Marechal Hermes, Continuo Nicanor, Pinheiro Machado e Barão de Teffé.

25.2 Notícias

25.2.1. Teatros

Depois de Pery assumir a direção do teatro São José, a Companhia Vitale fez questão de lá estrear.

\section{O Pirralho, número $157,17 / 10 / 1914$, ano IV}

25.2 Notícias

25.2.1. Palcos e Fitas. Demo

Trabalha no São José a Companhia Nacional de Operetas, Mágicas e Revistas sob a direção de J. Gonçalves. O grupo apresenta a revista de costumes paulistas Só p'ra falar, de Cardoso de Menezes.

"A revista tem seus defeitos e não pequenos, é mesmo um tanto apimentada, mas tem críticas felizes a fatos da vida paulistana e boa movimentação."

\section{O Pirralho, número 158, 24/10/1914, ano IV}

25.2 Notícias

25.2.1. Palcos e Fitas. Demo

Estréia da revista São Paulo Futuro, de Danton Vampré. A revista passou por uma série de modificações, entretanto, segundo o artigo, não foi suficiente para que se retirassem "as verdadeiras excrescências do seu trabalho".

\section{O Pirralho, número 159, 31/10/1914, ano IV}

25.2 Notícias

25.2.1. Palcos e Fitas. Demo

Empolga a platéia a companhia espanhola que atualmente trabalha no Palace Theatre. No Apolo, a Companhia Vitale continua oferecendo bons espetáculos. As revistas São Paulo Futuro e Só p'ra falar continuam em cartaz no São José.

\section{O Pirralho, número $160,07 / 11 / 1914$, ano IV}

\subsection{Notícias}

25.2.1. Palcos e Fitas. Demo

Quanto ao São José, o colunista informa: "A companhia nacional que trabalha ora neste teatro, ora no Colombo, ora nos Campos Elíseos, continua a fazer sucesso por onde passa". 


\section{O Pirralho, número $161,14 / 11 / 1914$, ano IV}

25.2 Notícias

25.2.1. Palcos e Fitas. Demo

O mais recente sucesso do São José é a apresentação de As Pupilas do Senhor Reitor.

\section{O Pirralho, número $163,28 / 11 / 1914$, ano IV}

25.2 Notícias

25.2.1. Palcos e Fitas. Demo

Programa da festa de encerramento das aulas do Conservatório Dramático e Musical de São Paulo, pelos alunos do curso de arte dramática, representando O Oráculo, de Arthur de Azevedo. No São José, a troupe de J. Gonçalves apresentou a opereta O Moleiro de Alcalá, de Eduardo Garrido.

\section{O Pirralho, número $164,05 / 12 / 1914$, ano IV}

25.2 Notícias

25.2.1. Palcos e Fitas. Demo

Em breve, a companhia de revistas e operetas, que trabalha no São José, apresentará São Paulo em Fraldas.

\section{O Pirralho, número $165,12 / 12 / 1914$, ano IV}

25.2. Notícias

25.2.1. Palcos e Fitas. Demo

O teatro esteve lotado com a estréia de São Paulo em Fraldas, que agradou completamente.

\section{O Pirralho, número $167,26 / 12 / 1914$, ano IV}

25.2 Notícias

25.2.1. Palcos e Fitas. E.M.

A companhia portuguesa de operetas e revistas apresentou a opereta Sonho fatal, de A Tavares, que figura entre as melhores peças da companhia.

\section{O Pirralho, número $168,02 / 01 / 1915$, ano IV}

\subsection{Notícias}

25.2.1. O Grêmio Dramático Santa Cecília encerrou uma série de recitas representando a burleta Uma Festa em Guabiroba, de Assis Pacheco. O artigo de J. Felizardo elogia a representação, apesar do amadorismo do grupo. 
25. O Pirralho, número 169, 09/01/1915, ano IV

25.2. Notícias

25.2.1. Notícia de Stiunirio Gama sobre o incêndio do teatro Polytheama.

25. O Pirralho, número 171, 23/01/1915, ano IV

25.2. Notícias

25.2.1. A atriz Lia Lapini faz sucesso no Palace Theatre.

25. O Pirralho, número 173, 06/02/1915, ano IV

25.2. Notícias

25.2.1. Realizou-se no São José um espetáculo em benefício das vítimas do terremoto ocorrido na Itália.

25. O Pirralho, número 174, 13/02/1915, ano IV

25.2. Notícias

25.2.1. Palcos e Fitas

Faz sucesso no São José a companhia de operetas de Leopoldo Fróes.

25. O Pirralho, número $175,20 / 02 / 1915$, ano IV

25.1. Peças de teatro, homenagens à classe teatral, escritos diversos de autores consagrados.

25.1.1. Por causa do corso. Classificada de Tragédia em um ato cômico. Peça curta, assinada por Pau d'água.

25. O Pirralho, número 176, 27/02/1915, ano IV

25.2. Notícias

25.2.1. Palcos e Fitas

Críticas à companhia que trabalha no São José.

25. O Pirralho, número 177, 06/03/1915, ano IV

25.2. Notícias

25.2.1. Palcos e Fitas

A troupe luso-brasileira, que trabalha no São José, não tem obtido sucesso.

25.2.2. Grêmio Dramático Santa Cecília

Em comemoração da posse da nova diretoria, o grupo amador, apresentou a revista Tim Tim Mirim. 


\section{O Pirralho, número $178,13 / 03 / 1915$, ano IV}

\subsection{Notícias}

25.2.1. Palcos e Fitas

Destaque para o sucesso da Companhia Leopoldo Fróes no São José.

25.4. Entrevistas, enquetes

25.4.1 "Em que se preocupavam os intelectuais cariocas?" Entrevista com os expoentes da nossa literatura; nesse número o entrevistado é Coelho Neto.

\section{O Pirralho, número $179,20 / 03 / 1915$, ano IV}

\subsection{Notícias}

25.2.1. Comentários sobre as montagens do drama $O$ Grilheta e da comédia $O$ Pintor, realizadas pelo Grêmio Dramático Santa Cecília.

25.4. Entrevistas, enquetes

25.4.1. A entrevista do número anterior é respondida agora por Goulart de Andrade.

\section{O Pirralho, número $180,27 / 03 / 1915$, ano IV}

25.1. Peças de teatro, homenagens à classe teatral, escritos diversos de autores consagrados.

25.1.1. O café subiu. Comédia em 1 ato de Esperança

\subsection{Crítica Teatral}

\subsubsection{Palco e Fitas}

O artigo comenta que o Teatro Municipal, tanto do Rio quanto de São Paulo, estão fechados e, portanto, colaboram para a decadência do teatro nacional. Apesar disso, o autor ressalta algumas tentativas de se fazer teatro no Brasil, como as de Coelho Neto e João do Rio.

\section{O Pirralho, número 181, 03/04/1915, ano IV}

\subsection{Crítica Teatral}

\subsubsection{Palco e Fitas}

A velha questão do Teatro Nacional agitou-se na imprensa carioca, com a vinda de uma companhia Argentina trazendo em seu repertório peças de autores brasileiros. São exigidas medidas do prefeito, que disse desconhecer a existência de artistas no Brasil.

\section{O Pirralho, número 183, 17/04/1915, ano IV}

\subsection{Notícias}

25.2.1. Palcos e fitas

Notícia sobre a montagem da revista Banho de Vênus, realizada pela companhia Eduardo Vieira. 


\section{O Pirralho, número $184,24 / 04 / 1915$, ano IV}

\subsection{Notícias}

\subsubsection{Palcos e Fitas}

Notícia sobre a montagem da revista Banho de Vênus, realizada pela companhia Eduardo Vieira. Destaque para o sucesso da peça O caça-dotes pela Companhia nacional Arruda rocha.

\section{O Pirralho, número $185,01 / 05 / 1915$, ano IV}

\subsection{Notícias}

\subsubsection{Palcos e fitas}

Faz sucesso a comédia Quarto Separado, de Pierre Weber, traduzida e adaptada pela artista Guilhermina Rocha.

\section{O Pirralho, número $186,08 / 05 / 1915$, ano IV}

25.2. Notícias

\subsubsection{Palcos e fitas}

Foi um sucesso a estréia da Companhia Galhardo com a revista $O$ 31, de Luís Galhardo, Pereira Coelho e Alberto Barbosa. $O$ artigo de J. Felizardo segue com comentários sobre a atuação dos atores.

\section{O Pirralho, número $187,15 / 05 / 1915$, ano IV}

\subsection{Notícias}

\subsubsection{Palcos e fitas}

A Companhia Galhardo mostrou-se uma companhia de primeira ordem, por isso já caiu nas graças paulistas. Representou as revistas: O 31, o Pão Nosso e O Mar de Rosas, de Apollo.

Os números organizados por Pery e Torino têm rendido muitos espetáculos. Merecem destaque: Jane Mamy, Visette de Verly e Irene Coty. No Royal Theatre, estréia a troupe Cinira Polônio, Izabel Lopes e Trajano Vaz.

\section{O Pirralho, número 188, 22/05/1915, ano IV}

\subsection{Crítica Teatral}

25.3.1. J. Felizardo anuncia que o público, cansado do gênero revista, em breve poderá apreciar uma companhia formada por grandes artistas, como Leopoldo Fróes, Lucília Peres e o comendador Matos. $\mathrm{O}$ autor segue comentando as peças em cartaz na cidade. 


\section{O Pirralho, número $189,28 / 05 / 1915$, ano IV}

25.2. Notícias

25.2.1. Palcos e fitas

J. Felizardo comenta as peças em cartaz na cidade.

\section{O Pirralho, número 191, 12/06/1915, ano IV}

25.2. Notícias

25.2.1. Cornélio Pires

Contrariando alguns críticos, Cornélio Pires alcançou sucesso mostrando seus números de canto e dança. No Palace Theatre, a Companhia Galhardo encerra sua temporada.

Iniciaram-se os benefícios com o ator cômico Carlos Leal, posteriormente, Irene Gomes, Philomena Lima, Carmem de Oliveira, Salles Ribeiro e José Moraes.

Destaca-se o benefício de Irene Gomes com a opereta $O$ Toreador.

\section{O Pirralho, número 192, 19/06/1915, ano IV}

\subsection{Crítica Teatral}

25.2.1. Palcos e fitas

J. Felizardo relata que a conflagração européia trouxe um benefício para a sociedade: a decadência do cinematógrafo. Segundo ele, essa instituição que se alastrou e cujos efeitos são nocivos como os do jogo do bicho, vem decaindo a cada dia. E agora, o cinema pede ajuda ao teatro, o qual prejudicou, e apresenta números de variedades para atrair público, mas nem sempre o faz com competência. No Casino Antártica, dentro de poucos dias, ocorrerá a estréia da Companhia Adelina Abranches-Alexandre de Azevedo.

25.4. Entrevistas, enquetes

25.4.1. Em entrevista, Luiz Edmundo afirma que espera poder representar pelo menos duas peças: $A$ Miragem e $O$ que não mata e a prova. Também escreve uma revista de ano com Oscar Lopes que pretende terminar em breve.

\section{O Pirralho, número 193, 26/06/1915, ano IV}

\subsection{Crítica Teatral}

\subsubsection{Palcos e Fitas}

O artigo prega a ressurreição do teatro nacional. Oscar Lopes e Álvaro Moreyra manifestam-se favoráveis ao ressurgimento do teatro nacional. A esperança, segundo acreditavam, estaria no surgimento de peças, como a comédia de costumes, que retratam a realidade do povo brasileiro. 


\section{O Pirralho, número 194, 03/07/1915, ano IV}

\subsection{Crítica Teatral}

\subsubsection{Palcos e Fitas}

Segundo a coluna, o teatro passava por um período de estagnação. Com o São José e o Palácio Teatro - considerados familiares- o público só tinha como opção o cinematógrafo.

25.4. Entrevistas, enquetes

25.4.1. Entrevista com João Luso e Paulo Filho sobre o atual estado das letras no Rio de Janeiro

\section{O Pirralho, número $195,10 / 07 / 1915$, ano IV}

\subsection{Notícias}

25.2.1. Palcos e Fitas

Anúncio da representação de Eva, de João do Rio.

\section{O Pirralho, número $196,17 / 07 / 1915$, ano IV}

\subsection{Notícias}

25.2.1. Boa estréia fez o Grêmio Dramático Santa Cecília, no dia 11 do corrente mês. Com um bom programa e organização, representou-se em primeiro lugar a comédia portuguesa Uma chavena de chá, cujos papéis foram assim distribuídos: Durval de Rebouças, o Barão de Sandomil; Antonietta Haro, a Baroneza de Sandomil; João Malta, Duarte Tinoco; D. Carvalho, o criado. Logo após, seguiu-se a apresentação da comédia de transformação (esatum Fregoli) escrita por A. Campos. A terceira peça do programa foi Um caipira em apuro.

\subsection{Crítica Teatral}

25.3.1. Lanterna Mágica. Eva

Ensaio de Oswald de Andrade sobre a peça Eva, de João do Rio.

25.3.2.Numa esquina

148.3.1. Uma crítica assinada por X sobre a peça Eva, de João do Rio.

\section{O Pirralho, número 197, 24/07/1915, ano IV}

\subsection{Notícias}

25.2.1. Xisto Bahia comenta os espetáculos em cartaz na cidade.

Estreou dia 19 a Companhia Huguenet. A estréia foi promissora, tendo a frente o artista francês. Além do ator, a companhia conta com excelentes artistas: Mlle Raphaele Osborne, Mlle. Vassor, Louis Rouyer e Magdeleine Carlier. No Casino Antártica, estréia da companhia Galhardo com a peça De Capote e lenço, gênero revista. 


\section{O Pirralho, número 201, 04/09/1915, ano V}

25.1. Peças de teatro, homenagens à classe teatral, escritos diversos de autores consagrados

25.1.1 Jararaca Véia

Poema satírico a Oswald de Andrade, escrito por Cornélio Pires.

25.2. Notícias

25.2. Coelho Neto trará a São Paulo Carmem Schindelar, uma bailarina clássica brasileira. A sua vinda deverá ser amparada pelo governo e pelo público.

\section{O Pirralho, número 202, 18/091915, ano V}

25.2. Notícias

25.2.1. Pelas artes

Estreará no Municipal o artista Titta Ruffo, em cujo repertório constam importantes peças do teatro lírico italiano, francês e alemão.

\section{O Pirralho, número 205, 30/10/1915, ano V}

25.2. Notícias

25.2.1. Anita é o nome da peça de Gomes Cardim e Olival Costa que alcançou grande sucesso. A peça conta um episódio da guerra do Contestado.

\section{O Pirralho, número 208, 11/12/1915, ano V}

25.1. Peças de teatro, homenagens à classe teatral, escritos diversos de autores consagrados 25.1.1. Madame é caprichosa, comédia em um ato de João Felpudo.

25.2. Notícias

25.2.1. J. Felizardo comenta a montagem da peça J. Pinho-Santos Dumont pelo Grêmio Dramático Santa Cecília

\section{O Pirralho, número 210, 08/01/1916, ano VI}

\subsection{Crítica Teatral}

25.3.1. Mon Coeur balance

Impressões de uma leitura realizada por Oswald de Andrade e Guilherme de Almeida da peça Mon Coeur balance.

\subsubsection{Mon Coeur balance}

Dolor de Brito, em um longo artigo, elogia a peça Mon Coeur Balance:

25.3.3. Mon Coeur balance

O artigo relata o que diz "O Estado" sobre a peça, comenta o enredo e a aceitação da crítica. 
25. O Pirralho, número 211, 22/01/1916, ano VI

25.3. Crítica Teatral

25.3.1. A propósito de Mon Coeur balance

O artigo faz uma crítica ao comentário da revista $O$ Queixoso sobre a peça.

25. O Pirralho, número 212, 08/02/1916, ano VI

25.1. Peças de teatro, homenagens à classe teatral, escritos diversos de autores consagrados

25.1.1. Poema de Athalia Binachi Betoldi em homenagem ao artista Titta Ruffo.

25.2. Notícias

25.2.1. De Camarote

Notícias dos espetáculos em cartaz na cidade.

Sucesso da companhia Esperanza Íris com a peça El mercado das muchachas.

25. O Pirralho, número 216, 04/04/1916, ano VI

25.2. Notícias

25.2.1. De Camarote

Notícias dos espetáculos em cartaz na cidade.

Sucesso da Companhia de operetas Maresca no Teatro Apolo com a opereta $A$ senhorita do cinematógrafo.

25. O Pirralho, número 218, 02/05/1916, ano VI

25.2. Notícias

25.2.1. Leur Âme

A nota informa que Oswald de Andrade e Guilherme de Almeida concluíram a peça Leur Âme, e que já estava em fase final a comédia A Escalada.

25. O Pirralho, número 220, 01/07/1916, ano VI

25.2. Notícias

25.2.1. Coisas de Arte

Anúncio de que em breve estariam à venda as peças Mon Coeur balance e Leur Âme, reunidas em um único volume.

25. O Pirralho, número 221, 29/07/1916, ano VI

25.3. Crítica Teatral

25.3.1. Mon Coeur balance e Leur Âme 
O artigo discute as críticas recebidas pelos autores por terem escrito as peças em francês. Após uma análise breve das peças, Antonio Define não titubeia em colocar Mon Coeur Balance acima de Leur Âme, "Quer sob o ponto de vista da técnica teatral, quer sob o ponto de vista estético e emotivo".

\section{O Pirralho, número 222,19/08/1916, ano VI}

\subsection{Notícias}

25.2.1. Modelo de crônica teatral

A peça Cesar Birotteau, que Emilio Fabre extraiu de um dos romances de Balzac, foi muito aplaudida no Municipal.

"Guitry, no papel de Birotteau, não esteve nada interior a Gemier, que foi quem o criou em Paris." A peça Samson, de Henry Bernstein, representada no Municipal, foi brilhantemente desempenhada pela companhia francesa, segundo a coluna.

\subsection{Crítica Teatral}

25.3.1. Cartas ao Jacinto

O articulista Totó critica os elogios dos jornalistas dirigidos a Lucien Guitry.

\section{O Pirralho, número 223, 30/09/1916, ano VI}

\subsection{Notícias}

25.2.1. Pirralho social

A nota destaca o sucesso das apresentações realizadas no Municipal e no São José.

\section{O Pirralho, número 228, 14/12/1916, ano VI}

\subsection{Notícias}

25.2.1. A companhia de Lugné Poe e Suzanne Després farão a representação de um ato de Leur Âme.

\section{O Pirralho, número 229, 31/12/1916, ano VI}

\subsection{Notícias}

\subsubsection{Flores de Sombra}

Considerado um dos primeiros trabalhos teatrais brasileiros, a comédia de costumes Flores de Sombra foi o maior sucesso teatral de 1916. A peça foi representada pela Companhia de Leopoldo Fróes, que, segundo o artigo, fez jus ao valor da obra, levando um enorme público ao teatro da Boa Vista. 


\section{O Pirralho, número $230,13 / 01 / 1917$, ano VI}

\subsection{Notícias}

25.2.1. Nota sobre o sucesso da Companhia de Leopoldo Fróes no teatro Boa Vista. O artigo elogia o trabalho do ator e dos outros artistas do grupo, com exceção ao de E. Pereira.

\section{O Pirralho, número $233,27 / 03 / 1917$, ano VI}

\subsection{Crítica Teatral}

25.3.1. O teatro Nacional. Uma entrevista com o Sr. Gomes Cardim.

$\mathrm{O}$ artigo, na verdade, é uma sátira d' $O$ Pirralho, em que o Sr. Gomes Cardim fala à revista sobre a queda e a ressurreição do teatro nacional.

\section{O Pirralho, número 234, 20/04/1917, ano VI}

24.2. Notícias

24.2.1. De camarote.

Notícias sobre a Companhia que trabalha no Boa Vista, e elogios à Itália Fausta, na montagem de $A$ mulher dez.

\section{O Pirralho, número $236,05 / 05 / 1917$, ano VI}

25.2. Notícias

25.2.1. De camarote.

A Companhia Nacional de Gomes Cardim estava preste a encerrar sua temporada. Este fato merece atenção, pois a companhia representa uma das muitas tentativas de ressurgimento do teatro nacional.

\section{O Pirralho, número $238,20 / 05 / 1917$, ano $\mathrm{VI}$}

25.2. Notícias

\subsubsection{Tesoura mundana}

A coluna faz uma sátira ao momento teatral, ao relembrar o comentário de Sarah Bernhardt de que São Paulo seria a Capital artística do país.

25.2.2. Teatro São José. Henrique Alves.

25.2.3. De camarote

Notícias sobre as peças em cartaz.

\section{O Pirralho, número 239, 22/06/1917, ano VI}

\subsection{Notícias}


Nota sobre os espetáculos em cartaz na cidade. Destaque para a Companhia Christiano de Souza, no Boa Vista.

25.3. Crítica Teatral

25.3.1. Gomes Cardim

Elogios à atuação de Gomes Cardim enquanto homem de teatro.

\section{O Pirralho, número $242,2^{\circ}$ quinzena de agosto de 1917 , ano VII}

25.2. Notícias

25.2.1. De camarote

Faz muito sucesso a Companhia Arruda neste teatro. Durante a quinzena, foram encenadas: $O$ Picareta, O recruta do 43, A festa no Ó, A Gran Via, A pensão de d. Ana, de Danton Vampré.

25.3. Crítica Teatral

25.3.1. De camarote

O artigo comenta a atuação da Companhia Brulé, no Municipal.

25.5 Fotos e charges

25.5.1 Fotos dos atores da Companhia Arruda

\section{O Pirralho, número $243,1^{\circ}$ quinzena de setembro de 1917 , ano VII}

25.1. Peças de teatro, homenagens à classe teatral, escritos diversos de autores consagrados 25.1.1. Teatro ao ar livre. Sem autoria.

25.3. Crítica Teatral

25.3.1. De camarote

Comentários acerca da representação de Uma festa na Freguesia do Ó, pela Companhia Arruda. Segundo o artigo a peça não é muito boa, assim como as atuações: "é uma conchamblance cheia de ditos picarescos e arrojados que os nossos avós não ouviriam com muito prazer".

\section{O Pirralho, número $244,2^{\circ}$ quinzena de setembro de 1917 , ano VII}

25.1. Peças de teatro, homenagens à classe teatral, escritos diversos de autores consagrados

25.1.1. Arroubos Poéticos. Comédia sentimental em duas cenas. Sem autoria.

25.3. Crítica Teatral

\subsubsection{De camarote}

A Companhia Arruda encena a revista O Recruta do 43, de Guedes e Cotó. Segundo a crítica a peça segue "o estafadíssimo chavão importado de Portugal, com isenção de direitos aduaneiros": O enredo gira em torno do caipira que vem a São Paulo e conhecerá a cidade acompanhado de 
um recruta do 43.

25. O Pirralho, número $245,2^{\circ}$ quinzena de outubro de 1917 , ano VII

25.1. Peças de teatro, homenagens à classe teatral, escritos diversos de autores consagrados 25.1.1. O coronel. Sem autoria.

25.3. Crítica Teatral

25.3.1. De camarote

Comentários acerca da atuação da Companhia Arruda.

25. O Pirralho, número 246, 2 ㅇ quinzena de novembro de 1917 , ano VII

25.1. Peças de teatro, homenagens à classe teatral, escritos diversos de autores consagrados 25.1.1. O pianista. Sem autoria.

25.3. Crítica Teatral

25.3.1. De camarote

Comentários acerca da atuação da Companhia Arruda. O artigo centra-se na representação da revista A Grande Fita, de Pedro Monte Ablas.

25. O Pirralho, número 247, 31/01/1918, ano VII

25.1. Peças de teatro, homenagens à classe teatral, escritos diversos de autores consagrados 25.1.1. Idílio Infantil. Sem autoria.

25.3. Crítica Teatral

25.3.1. De camarote

Comentários de Conde Danilo a respeito sobre a peça Mau jeito, representada pela Companhia Arruda.

25. O Pirralho, número 248, 25/02/1918, ano VII

25.3. Crítica Teatral

25.3.1. De camarote

A última novidade da companhia Arruda foi a burleta Gente Moderna, de Francisco Barroso e Nascimento Filho.

26. O Queixoso, número $1,09 / 12 / 1915$, ano I

Acervo: Biblioteca Nacional

26.2. Notícias 


\subsubsection{Teatros}

Notícias sobre as peças em cartaz na cidade. Crítica assinada por W. Kiritiko sobre as peças representadas pela companhia portuguesa que se encontrava no Casino Antarctica. Há também comentários a respeito das companhias que estão no São José e Apollo. (pp.12-13)

\section{O Queixoso, número $2,23 / 12 / 1915$, ano I}

\subsection{Fotos}

26.5.1. Fotografia de Palmyra Bastos, atriz que representou a Viúva Alegre no Casino Antarctica. 26.5.2 Foto de Cremilda de Oliveira da troupe Galhardo, na peça Amor de Zíngaros.

\section{O Queixoso, número $3,13 / 01 / 1916$, ano I}

26.2. Notícias

26.2.1. Nota sobre o sucesso da trupe de Afonso Arinos.

\subsection{Teatros}

Notícias sobre as peças em cartaz na cidade.

26.3. Crítica Teatral

26.3.1. A propósito de Mon Coeur balance... Peça de Guilherme de Almeida e Oswaldo (sic) de Andrade.

O articulista Brutus defende os autores, que foram muito criticados pela imprensa por terem escrito a peça em francês.

\section{O Queixoso, número $4,29 / 01 / 1916$, ano I}

26.2. Notícias

26.2. 1. Teatros

Notícias sobre as peças em cartaz na cidade. Abrindo a seção, consta uma crítica às companhias "mambembes", organizadas às pressas no Rio de Janeiro para excursionar por São Paulo.

26. O Queixoso, número $5,10 / 02 / 1916$, ano I

26.1. Notícias

26.2. Teatros

Notícias sobre as peças em cartaz na cidade.

\section{O Queixoso, número $6,25 / 02 / 1916$, ano I}

26.1. Notícias 
26.2. Teatros

Notícias sobre as peças em cartaz na cidade.

26. O Queixoso, número $7,17 / 03 / 1916$, ano I

26.1. Notícias

26.2. Teatros

Notícias sobre as peças em cartaz na cidade.

26. O Queixoso, número 8, 06/04/1916, ano I

26.1 Peças de teatro, homenagens à classe teatral, escritos diversos de autores consagrados

26.1.1. AZEVEDO, Artur: $O$ fato do ator Silva.

Conto

27. Revista do Brasil, número 2, 02/1916, ano I, vol I

Acervo: IEB

27.5. Fotos e charges

27.5.1. Duas charges ironizando o Teatro Nacional (p.231)

\section{Revista do Brasil, número $8,08 / 1916$, ano I, vol III}

\subsection{Notícias}

27.2.1. Artigo anônimo sobre a companhia do ator francês Guitry.

O artigo elogia a montagem das peças Pétard, de Henri Lavedan e Miette, de Dario Niccodemi. Segundo o autor, o sucesso de Miette, provou que o público estaria fatigado "do adultério e das trampolinagens que o moderno teatro francês obstinadamente lhe serve". (p.388)

\section{Revista do Brasil, número 9, 09/1916, ano I, vol III}

27.2. Notícias

27.2.1. Nota sobre a visita de Isadora Duncan a São Paulo. (p.99)

27. Revista do Brasil, número 10, 10/1916, ano I, vol. III

27.2. Notícias

27.2.1. Nota sobre a tradução de Dom Casmurro, feita por Antonio Piccarolo. (p.173) 


\section{Revista do Brasil, número 15, 03/1917, ano II, vol. IV}

\subsection{Notícias}

27.2.1. Nota sobre a tentativa de organização de uma companhia paulista. (pp.326-327)

27.3. Crítica Teatral

27.3.1. Artigo de Olavo Bilac a respeito da peça A Renúncia, de Cláudio de Souza. (pp.326-327)

\section{Revista do Brasil, número $17,05 / 1917$, ano II, vol. V}

\subsection{Crítica Teatral}

\subsubsection{Movimento Teatral}

Artigo de Tobias Monteiro sobre o encerramento da temporada da Companhia Dramática, de Gomes Cardim. (pp.109-111)

\section{Revista do Brasil, número $18,06 / 1917$, ano II, vol. V}

\subsection{Crítica Teatral}

27.3.1. Artigo reproduzido da Revue Hebdomadaire, assinado por Alfred Capus, intitulado $O$ teatro Francês e a Guerra. O texto aborda uma conferência realizada pelo diretor do Teatro Antoine, Sr. Gémier, acerca da decadência do teatro francês antes da guerra.(pp.262-263)

\section{Revista do Brasil, número 25, 01/1918, ano III, vol. VII}

\subsection{Crítica Teatral}

27.3.1. Artigo intitulado O nosso teatro, de Carlos de Laet, reproduzido de Jornal do Brasil (Rio de Janeiro), retratando como a opereta e a revista contribuíram para o declínio do teatro feito no Brasil. (pp.98-99)

\section{Revista do Brasil, número $28,04 / 1918$, ano III, vol. VII}

\subsection{Crítica Teatral}

27.3.1. O teatro francês e a guerra.

Reproduzido de Le Temps, e assinado por Adolphe Brisson, o texto discorre sobre a decadência do teatro francês. (pp.425-426)

27. Revista do Brasil, número 29, 05/1918, ano III, vol. VIII

\subsection{Crítica Teatral}

\subsubsection{O Teatro Português.}

Críticas ao teatro de Portugal; por Julio Dantas de O Primeiro de Janeiro, Porto. Conforme o autor, é indispensável que os artistas se especializem para que seja garantida a harmonia entre atores e ensaiadores. (pp.99-100) 
27. Revista do Brasil, número 30, 06/1918, ano III, vol. VIII

27.1 Peças de teatro, homenagens à classe teatral, escritos diversos de autores consagrados

27.1.1. Reprodução de uma carta de Antonio Luis Fernandes da Cunha, endereçada a José de Alencar. (pp.172-173)

27. Revista do Brasil, número 32, 08/1918, ano III, vol VIII

27.1 Peças de teatro, homenagens à classe teatral, escritos diversos de autores consagrados

27.1.1. CARVALHO, Vicente. Luizinha. (pp.392-405)

\section{Revista do Brasil, número $35,11 / 1918$, ano III, vol IV}

27.1 Peças de teatro, homenagens à classe teatral, escritos diversos de autores consagrados

27.1.1. Reprodução de uma carta de Visconde de Sapucaí endereçada a José de Alencar.(p.348)

27. Revista do Brasil, número $36,12 / 1918$, ano III, vol IX

27.2. Notícias

27.2.1. Nota sobre a tradução da peça Cyrano de Bergerac, feita por Ricardo Gonçalves. (p.405)

\section{Revista do Brasil, número $38,02 / 1919$, ano IV, vol. X}

\subsection{Crítica Teatral}

27.3.1. A prosódia brasileira no teatro, de Júlio Nogueira. Reproduzido do Jornal do Comércio, Rio de Janeiro. O ensaio aponta a prosódia estrangeira utilizada nos palcos como um obstáculo para o crescimento do teatro brasileiro.(pp.237-238)

\section{Revista do Brasil, número 39, 03/1919, ano IV, vol. X}

\subsection{Crítica Teatral}

27.3.1. Do teatro, de Leo Vaz, reproduzido do Estado de São Paulo. (pp.364-366)

Leo Vaz afirma que o teatro brasileiro não estaria em decadência, mas sim caminhando "no nível mediano das coisas". Afinal, não teríamos tido tempo, como os europeus, para desenvolver a arte teatral, segundo informa.

\section{Revista do Brasil, número 43, 10/1919, ano IX, vol. XII}

27.3. Crítica Teatral

27.3.1. Cinematógrafos

Artigo sobre o crescimento dos cinematógrafos e do aumento pela sua procura. (pp.185-186) 


\section{Revista do Brasil, número 55, 07/1920}

\subsection{Crítica Teatral}

26.3.1. O texto aborda as conferências de Mauricio Maeterlinck na América do Norte. Reproduzido de $A$ Rua, Rio de Janeiro. (p.272)

27.3.2. O Nacionalismo na Arte.

O artigo tece considerações a respeito da desvalorização do artista nacional. Artigo reproduzido de Diário de Minas e assinado por Fly.(.p.281)

\section{Revista do Brasil, número 57, 09/1920}

27.1 Peças de teatro, homenagens à classe teatral, escritos diversos de autores consagrados 27.1.1.- Fragmentos da peça Myriam, de Carlos Dias Fernandes. (p.20)

\section{Revista do Brasil, número 59, 11/1920.}

27.1 Peças de teatro, homenagens à classe teatral, escritos diversos de autores consagrados 27.1.1. Primeiro quadro de Maria Madalena, de Baptista Cepellos. (pp.210-224)

27.2. Notícias

27.2.1. Abertura de um Concurso literário que premiará uma peça de teatro. (p. 271)

\section{Revista do Brasil, número $60,12 / 1920$}

27.1 Peças de teatro, homenagens à classe teatral, escritos diversos de autores consagrados 27.1.1. Segundo quadro de Maria Madalena, de Baptista Cepellos. (pp. 303 -318)

\section{Revista do Brasil, número 61, 01/1921}

27.1 Peças de teatro, homenagens à classe teatral, escritos diversos de autores consagrados 27.1.1. Terceiro quadro de Maria Madalena, de Baptista Cepellos. (pp. 52-57)

\section{Revista do Brasil, número 62, 04/1921}

27.1 Peças de teatro, homenagens à classe teatral, escritos diversos de autores consagrados 27.1.1. Último quadro de Maria Madalena, de Baptista Cepellos. (pp. 148-154)

\section{Revista do Brasil, número 64, abril-junho/1921, ano VI, vol. XVII}

\subsection{Crítica Teatral}

27.3.1. SOUZA, Cláudio. Verdade e verossimilhança

Cláudio de Souza, a respeito de críticas à sua peça Bonecos articulados, tece considerações a sobre a verdade e a verossimilhança no teatro. (pp.69-70) 
27. Revista do Brasil, número 69, 09/1921, ano VI, vol. XVIII

27.1 Peças de teatro, homenagens à classe teatral, escritos diversos de autores consagrados

27.1.1. Uma cena de O Filho, de Mario Sette. (p.9)

27.1.2. Episódio Dramático: Coração de Caboclo, de Rodrigo Octavio. (p.34)

27. Revista do Brasil, número $70,10 / 1921$ ano $\mathrm{VI}$, vol. XVIII

27.2. Notícias.

27.2.1. Considerações a respeito do envolvimento entre Eleonora Duse e D’Annunzio.

27. Revista do Brasil, número $77,08 / 1922$, ano VII, vol. $X X$

27.1 Peças de teatro, homenagens à classe teatral, escritos diversos de autores consagrados

27.1.1. Grand Guignol (ato único), de Costa Rego, reproduzido do Correio da Manhã.

27. Revista do Brasil, número 82, 10/1922, ano VII, vol. XXI

27.3. Crítica Teatral

29.3.1. Na seção Debates e pesquisas, há um extenso artigo intitulado Cem anos de Teatro, que faz um panorama do teatro de Anchieta até o momento em que aparecem artistas como Apolônia Pinto e Cinira Polônio. Artigo reproduzido de O Jornal e assinado por Otávio Quintiliano.

27. Revista do Brasil, janeiro, fevereiro e março/1922, sem número de revista, ano ou volume.

Não há artigos referentes a teatro.

28. Revista Feminina, dezembro/1916, janeiro /1917, ano 13

Acervo: Arquivo do Estado de São Paulo

30.3. Crítica Teatral

30.3.1. Flores de Sombra

O ensaio ressalta as qualidades literárias de Cláudio de Souza.

\section{Revista Nacional, número 5, fevereiro de 1922}

Acervo: IEB

29.2. Notícia 
29.2.1. Notícia sobre as festas em comemoração à Independência em São Paulo. Uma das realizações é a apresentação da ópera nacional Dom Casmurro, de João Gomes Junior, montagem da Empresa de Walter Mocchi. (p.51)

\section{Revista Nacional}

Os números correspondentes aos meses de outubro a dezembro de 1921, e março a dezembro de 1922 não apresentam artigos sobre teatro.

\section{Revista Santa Cruz, janeiro de 1913, ano XIII}

Acervo: Arquivo do Estado de São Paulo

30.1 Peças de teatro, homenagens à classe teatral, escritos diversos de autores consagrados

30.1.1. Mistério em 5 quadros, prosa e verso: Nossa Senhora de Lourdes, de Benedicto Otávio. (pp.24 a 28)

\section{Revista Santa Cruz, fevereiro de 1913, ano XIII}

30.1. Peças de teatro, homenagens à classe teatral, escritos diversos de autores consagrados 30.1.1. Continuação do Mistério Nossa Senhora de Lourdes. (pp. 65 a 68)

30.2. Notícias

30.2.1. Notícia sobre a conferência de Coelho Neto e Récita de Pastoral. (p.127)

\section{Revista Santa Cruz, abril de 1913, ano XIII}

30.1. Peças de teatro, homenagens à classe teatral, escritos diversos de autores consagrados 30.1.1. Continuação do Mistério Nossa Senhora de Lourdes. (pp. 155 a 158)

\section{Revista Santa Cruz, maio de 1913, ano XIII}

30.1. Peças de teatro, homenagens à classe teatral, escritos diversos de autores consagrados 30.1.1. Continuação do Mistério Nossa Senhora de Lourdes. (pp. 155 a 158)

\section{Revista Santa Cruz, julho de 1913, ano XIII}

30.1. Peças de teatro, homenagens à classe teatral, escritos diversos de autores consagrados 30.1.1. Continuação do Mistério Nossa Senhora de Lourdes.. (pp. 272 a 274)

\section{Revista Santa Cruz, dezembro de 1913, ano XIII}

30.3. Crítica Teatral 
30.3.1. Um ensaio de Gastão Câmara Leal, de Taubaté, ressaltando a importância do teatro como espaço de diversão e como escola de bons costumes. (pp. 477-478)

\section{Revista Santa Cruz}

Os números de agosto a novembro de 1913 não apresentam artigos sobre teatro.

\section{Revista Teatral/ Teatro, Sport, Arte e ...o que for, número 7, 23/04/1914, ano I}

Acervo: Biblioteca Mário de Andrade

31.1. Peças de teatro, homenagens à classe teatral, escritos diversos de autores consagrados

31.1.1. Os progressos da ciência. "Monólogo para homem", de Francisco Ferreira.

31.2. Notícias

31.2.1. A Semana. D. Pasquale

A seção faz um resumo do que estava acontecendo na cena paulistana.

O sucesso da opereta Papá Guilherme, da companhia do ator Brandão, no São José, é o assunto principal da semana.

\subsubsection{São Paulo em Fraldas}

Elogio à leitura da revista, realizada por seus autores Ricardo de Oliveira, E. Paiva Rio e maestro Bentinho Cintra. Segundo o artigo, a revista estava destinada ao sucesso, pois era muito bem elaborada, "bem feita, com espírito, e, sobretudo, sem pornografia".

31.3. Crítica Teatral

\subsubsection{Teatro Nacional}

É discutida a apresentação do projeto do coronel Leite Ribeiro ao Conselho Municipal, sobre o teatro nacional. Há uma transcrição de um comentário, publicado no jornal carioca $O$ Imparcial, criticando o projeto, pois as subvenções seriam uma forma de beneficiar empresários e prejudicar a arte dramática.

\section{Revistinha, $1897 / 1901$}

Acervo: IEB

32.1. Peças de teatro, homenagens à classe teatral, escritos diversos de autores consagrados

32.1.1. Onde está a felicidade? Mistério em 2 quadros de Figueiredo Pimentel 


\section{A Ronda, número II, 21/05/1914, ano I}

Acervo: IEB

33.2. Notícias

33.2.1. Teatro. Talma.

O artigo lamenta a decadência do teatro, que se devia em grande parte, segundo o autor, às peças levadas à cena, incomparáveis às anteriores, as quais representavam uma escola de moral e de bons ensinamentos.

O texto traz a reprodução de um fragmento de Talma sobre o teatro.

"Uma das mais belas concepções humanas, no terreno das Artes, é incontestavelmente o teatro: verdadeira alavanca do progresso, a ele devemos parte do desenvolvimento intelectual de hoje. Todos reconhecem a poderosa influência do teatro na história da humanidade, e, não obstante isso, no século atual, ele decai, lutando com o indiferentismo do público que, se o não protesta, também o não procura, indiferença essa que não há de reduzi-lo e por fim dizimá-lo, se uma nova corrente de simpatia não o salvar desse letargo em que jaz."

\section{A Ronda, número IV, 28/06/1914, ano I}

33.5. Fotos

33.5.1. Foto da atriz Júlia Lopes, da trupe Brandão.

\section{A Vida Moderna, 15/06/1907, ano II}

Acervos: Biblioteca da Escola de Comunicações e Artes (ECA), Biblioteca Mário de Andrade

34.2. Notícias

34.2.1. Artes e Teatros

No Polytheama, destaca-se o trabalho da Companhia Vitale. (p. 10)

\section{A Vida Moderna, 29/06/1907, ano II}

\subsection{Notícias}

34.2.1 Notícias das peças em cartaz na cidade. (p. 13)

\section{A Vida Moderna, 13/07/1907, ano II}

\subsection{Notícias}

O atual programa do Moulin Rouge é um "excelente biógrafo com vistas de sensação", além de cantoras e bailarinas francesas e espanholas. (p. 11) 


\title{
34. A Vida Moderna, número 21, 31/07/1907, ano II
}

\author{
34.2. Notícias
}

\subsubsection{Artes e Teatros}

No Polytheama, a Companhia de Operetas, Mágicas e Revistas dirigida pelo ator Brandão tem feito concorrência aos outros teatros.Uma peça de sucesso é a revista de costumes portugueses Tim Tim por Tim. A programação da próxima semana é a revista Capital Federal. (p. 13)

\section{A Vida Moderna, número 22, 17/08/1907, ano II}

\subsection{Notícias}

\subsubsection{Polytheama. Empresa J. Cateyssou}

Devido aos esforços do empresário J. Cateyssou têm vindo a São Paulo inúmeras companhias, como a da atriz Eleonora Duse, a companhia dos atores Salvini e Bolognesi, uma companhia lírica e uma de operetas, a Vitale.

Enquanto isso, a companhia Brandão está conquistando a simpatia do público. A representação da burleta Capital Federal foi um sucesso: "A peça está bem montada, cenários luxuosos, magníficos, nada faltando para o completo êxito da representação".

A Capital Federal sucedeu a Ilha do Paraíso (Rio de Janeiro), de Tito Martins e do ator Colás. "A revista é digna de ser apreciada, não só pelo seu magnífico desempenho, como ainda pela espirituosas críticas, que aí se desenrolam de princípio ao fim".

\section{A Vida Moderna, número 23, 31/08/1907, ano II}

34.2. Notícias

\subsubsection{Artes e Teatros}

A representação de Aída, por uma Companhia lírica de primeira ordem, foi um grande acontecimento. Após esta representação, assistiu-se a ópera Madame Butterfly, de Puccini.

\section{A Vida Moderna, número 24, 17/09/1907, ano II}

\subsection{Notícias}

\subsubsection{Artes e Teatros}

Estreou com grande sucesso a companhia Cômico Italiana Marchetti.

"O público paulista tem gosto e ama a arte dramática, principalmente no gênero adotado por essa rapaziada alegre e folgazã... As peças até hoje levadas por esta companhia, representam o que pode haver de mais original e novo no gênero cômico que é a sua especialidade". 
O repertório compõe-se de mais de setenta peças. No Polytheama, a companhia Brandão não obteve muito êxito com a representação da revista Vai ou Racha, de Assis Pacheco (?) ${ }^{1}$.

"Esta peça não passou de um verdadeiro conto do vigário, muito pecando pela absoluta falta de espírito e nexo".

É esperada a estréia da companhia eqüestre e ginástica de Frank Brown. (pp. 10-12)

\section{A Vida Moderna, número 25, 15/10/1907, ano II}

34.2. Notícias

\subsubsection{Artes e Teatros}

Esperava-se ansiosamente o admirável esmagamento de Marino por um automóvel de dois mil quilos e os espetáculos de luta romana. O Polytheama entrará em reformas, a fim de reabrir com a trupe do ator cômico Maldacéa. (p. 16)

\section{A Vida Moderna, número 27, 15/11/1907, ano II}

34.2. Notícias

34.2.1. Artes e Teatros

Destaque para a Companhia Città di Milano, dirigida pelo ator Luiggi Call, com o ator Maldacéa.

\section{A Vida Moderna, números 29 e 30, 25/12/1907, ano II}

\subsection{Notícias}

34.2.1. Artes e Teatros

O crítico considerou o ano de 1907 como sendo de uma "fecundidade artística notável. No Polytheama, o público apreciou a Companhia Vitale, e, em seguida, a Companhia Italiana de Antonio Bolognesi. Também mereceram menções a Companhia Lírica litaliana, e a Companhia do ator Brandão, representando comédias.

\section{A Vida Moderna, número 33, 18/02/1908, ano III}

\subsection{Notícias}

34.2.1. Artes e Teatros

A empresa Paschoal Segreto inaugurará um cinematógrafo no Santana.

\section{A Vida Moderna, 15/11/1908}

34.2. Notícias

34.2.1. Artes e Teatros

${ }^{1}$ (?) Observação contida no Original. 
Homenagem de despedida a Artur Azevedo.

\section{A Vida Moderna, número $84,28 / 11 / 1911$, ano IV}

34.2. Notícias

34.2.1. Teatros

No Polytheama, a Companhia Vitale continua a agradar os freqüentadores desse teatro. As belíssimas operetas são representadas com o garbo e capricho pela sua correta trupe, segundo o colunista.

\subsection{Crítica Teatral}

34.3.1. A ordem pública nos teatros.

O assunto tratado é o desrespeito, tanto do público quanto dos artistas, dentro do teatro, principalmente nos de variedades, que já são considerados "focos de libertinagem".

\section{A Vida Moderna, número 98, 04/01/1912, ano VII}

34.2. Notícias

34.2.1. Teatro de Amadores. Caramuru.

Uma nova sessão destinada aos atores iniciantes e a todos os amantes de teatro. Eram poucos os teatros em que ainda se podia ver uma peça de qualidade, em vez das "abomináveis pochades", segundo o crítico. Assim, essa nova sessão se dedicaria a falar desses locais quase esquecidos.

34. A Vida Moderna, número 100, 18/01/1912, ano VII

34.1. Peças de teatro, homenagens à classe teatral, escritos diversos de autores consagrados 34.1.1. Fashion. Comédia em um ato por Henri Duvernois.

\section{A Vida Moderna, número 104, 15/02/1912, ano VII}

34.1. Peças de teatro, homenagens à classe teatral, escritos diversos de autores consagrados 34.1.1. A morte de Pierrot. Poema dramático em um ato, em verso, de Júlio César da Silva.

\section{A Vida Moderna, número 135, 19/09/1912, ano VII}

\subsection{Notícias}

34.2.1. Homenagem a Ermete Novelli.

18.2.2. Pelas Ribaltas

O teatro São José foi reaberto com a Companhia Caramba.

34.3. Crítica Teatral 


\subsubsection{O Teatro Digestivo}

Trecho extraído de uma revista italiana com as seguintes observações de um médico, sobre a influência do teatro na digestão: "O teatro sofre uma evolução perfeitamente consentânea com as máximas da higiene. Abandonou as mais belas tragédias e deu agasalho às peças de gênero alegre, de agradável desfecho e à pochade".

\section{A Vida Moderna, número 279, 13/01/1916, ano XI}

34.1. Peças de teatro, homenagens à classe teatral, escritos diversos de autores consagrados 34.1.1. $O$ ator Mattos

Homenagem ao ator Mattos, falecido aos 66 anos.

34.3. Crítica Teatral

34.3.1. Mon Coeur Balance

O artigo trata da leitura da peça de Oswald De Andrade e Guilherme de Almeida. 19.2. 34.1.

\section{A Vida Moderna, número 302, 28/12/1916, ano XII}

34.2. Notícias

34.2.1. Artes e Letras

Notícia sobre a representação de um ato da peça Leur Âme realizada pela atriz Suzanne Després.

\section{A Vida Moderna, número 309, 12/04/1917, ano XIII}

\subsection{Crítica Teatral}

\subsubsection{Teatro Nacional}

O artigo louva as iniciativas de artistas como Itália Fausta e Lucília Peres, que contribuem para a valorização do nosso teatro.

\section{A Vida Moderna, número ilegível, 11/06/1918, ano XIV}

34.2. Notícias.

34.2.1. Nota sobre o sucesso da peça A Divina Encrenca, representada pela Companhia Arruda, no Boa Vista.

34.5. Fotos

34.5.1. Uma apoteose da burleta. A Divina Increnca, de Juó Bananére.

34. A Vida Moderna, número 340, 25/07/1918, ano XIV

34.3. Crítica Teatral 
34.3.1. Aniversário da Companhia Arruda

Artigo em comemoração ao aniversário de instalação da Companhia Arruda no teatro Boa Vista.

34. A Vida Moderna, número 341, 13/08/1918, ano XIV

34.3. Crítica Teatral

24.1.1. Danton Vampré

O artigo fala sobre Danton Vampré, um autor que se sobressai na cena paulistana como autor de burletas de sucesso.

\section{A Vida Moderna, 11/09/1918, ano XIV}

\subsection{Crítica Teatral}

34.3.1. Artigo elogiando a carreira do ator Prata. "Dotado de uma veia cômica excepcional sabe divertir enormemente o público."

\section{A Vida Moderna, número 352, 12/02/1919, ano XV}

34.3. Crítica Teatral

34.3.1. Pelos teatros

O texto aborda a decadência do teatro brasileiro e ressalta a importância de Arlindo Leal como crítico e dramaturgo.

\section{A Vida Moderna, 10/07/1919, ano XV}

34.3. Crítica Teatral

34.3.1. Artistas e teatros.

O artigo afirma que o Teatro Nacional, após um período de estagnação, começa a dar sinais de melhora. A peça de Viriato Correia, A Juriti, seria um exemplo da nova fase do nosso teatro.

\section{A Vida Moderna, número 363, 24/07/1919, ano XV}

34.2. Notícias.

34.2.1. Circuito das peças em cartaz na cidade.

34.2.2. Nota sobre a tradução de Le roi s'amuse, feita por Olavo Bilac.

34.3. Crítica Teatral

34.3.1. Artes e artistas. O drama moderno.

Considerações acerca do drama moderno, segundo Maeterlinck. 
34. A Vida Moderna, número 364, 07/08/1919, ano XV

34.2. Notícias.

34.2.1. Dom Casmurro

João Gomes Junior pretende levar à cena, na próxima temporada lírica, a peça musicada Dom Casmurro, adaptada do romance de Machado de Assis.

34. A Vida Moderna, número 369, 30/10/1919, ano XV

34.2. Notícias

34.2.1. Comentários desfavoráveis a peças estrangeiras.

34.3. Crítica Teatral

34.3.1. Pelas ribaltas. O Teatro Brasileiro.

Críticas ao teatro realizado no Brasil.

34. A Vida Moderna, número 371, 27/11/1919, ano XV

34.2. Notícias

34.2.1. Pelas ribaltas.

Críticas a um ator brasileiro que se dizia mexicano, só para obter sucesso.

34. A Vida Moderna, número 374, 15/01/1920, ano XVI

34.3. Crítica Teatral

34.3.1. A opereta. O que é a opereta?

$\mathrm{O}$ artigo aborda o nascimento da opereta.

34. A Vida Moderna, número 376, 12/02/1920, ano XVI

34.2. Notícias.

34.2.1. São José

Estréia a companhia de Leopoldo Fróes com a peça Longe dos Olhos, de Abadie Faria Rosa.

34.3. Crítica Teatral

34.3.1. Pelas ribaltas O Teatro Nacional

$\mathrm{O}$ artigo discute a situação do teatro nacional e sua decadência.

34. A Vida Moderna, número 377, 20/02/1920, ano XVI

34.3. Crítica Teatral

34.3.1. Pelas ribaltas. Revistomania 
O texto, assinado por Claudio, aborda a decadência do teatro brasileiro. Conforme o autor, a nossa cena teatral é dominada pelas revistas, que não possuem caráter literário.

34. A Vida Moderna, número $378,10 / 03 / 1920$, ano XVI

34.2. Notícias

34.2.1. Nota sobre o sucesso da companhia de Leopoldo Fróes.

34. A Vida Moderna, número $379,25 / 03 / 1920$, ano XVI

34.2. Notícias

34.2.1. Pelas ribaltas

Despedida da Companhia do ator Arruda do São José. Comentários a respeito da atuação da Companhia.

34. A Vida Moderna, número 380, 08/04/1920, ano XVI

34.2. Notícias

34.2.1. Pelas ribaltas

Informações sobre as peças em cartaz na cidade.

34. A Vida Moderna, número 385, 24/06/1920, ano XVI

34.2. Notícias

34.2.1. Pelas ribaltas

O título da peça de Danton Vampré e Josino Vianna que está fazendo sucesso é $A$ máscara.

34.3. Crítica Teatral

34.3.1. O Tesouro da feiticeira:

O artigo trata da opereta $O$ Tesouro da feiticeira, de Gomes Cardim e música do maestro Antonio Candido.

35. Vida Paulista, número 119, 17-18/05/1908, ano III

Acervo: IEB

35.2. Notícias

35.2.1. A luz da ribalta

Notícias sobre as peças em cartaz na cidade

35.3. Crítica Teatral

35.3.1. O teatro por Dentro. 
Ensaio de Augusto de Mello, que relata falhas ocorridas em cena durante os espetáculos.

35. Vida Paulista, número 120, 24-25/05/1908, ano III

35.2. Notícias

35.2.1. A luz da ribalta

Notícias sobre as peças em cartaz na cidade.

35. Vida Paulista, número 121, 31/05 e 01/06/1908, ano III

35.2. Notícias

35.2.1. A luz da ribalta

Notícias sobre as peças em cartaz na cidade.

35. Vida Paulista, número 122, 07 e 08/06/1908, ano III

35.2. Notícias

35.2.1. Notícias sobre as peças em cartaz na cidade.

35.3. Crítica Teatral

35.3.1. Trinta e cinco anos de teatro. Recordações de um vaudevillista

Alexandre Bisson conta a um jornalista francês um episódio de sua vida de "vaudevillista".

35. Vida Paulista, número 123, 14 e 15/06/1908, ano III

35.2. Notícias

35.2.1. A luz da ribalta

Notícias sobre as peças em cartaz na cidade.

35. Vida Paulista, número 124, 21 e 22/06/1908, ano III 35.2. Notícias

35.2.1. Notícias sobre as peças em cartaz na cidade.

35. Vida Paulista, número 125, 28 e 29/06/1908, ano III 35.2. Notícias

35.2.1. A luz da ribalta

Notícias sobre as peças em cartaz na cidade.

35.3. Crítica Teatral

35.3.1. Artigo sobre a valorização crescente do cinematógrafo. 
35. Vida Paulista, número 126, 4 e 5/07/1908, ano III

35.2. Notícias.

35.2.1. À luz da ribalta

Notícias sobre as peças em cartaz na cidade.

35.5. Fotos

35.5.1. Foto da atriz Tina di Lorenzo.

35. Vida Paulista, número 127, 12 e 13/07/1908, ano III 35.2. Notícias.

35.2.1. À luz da ribalta

Nota elogiando a atuação da atriz Tina di Lorenzo em peças como, $A$ bela samaritana, de Rostand e O Dote, de Artur Azevedo.

35. Vida Paulista, número 128, 19 e 20/07/1908, ano III

35.2. Notícias.

35.2.1. À luz da ribalta

Notícias sobre as peças em cartaz na cidade.

35.5. Fotos e charges

Charge sobre a utilização de chapéus dentro do teatro.

35. Vida Paulista, número 129, 26/07/1908, ano III 35.2. Notícias.

35.2.1. À luz da ribalta

Notícias sobre as peças em cartaz na cidade.

35. Vida Paulista, número 130, 2 e 3/08/1908, ano III

35.1. Peças de teatro, homenagens à classe teatral, escritos diversos de autores consagrados 35.1.1 AZEVEDO, Artur. Por causa da Tina.

Teatro a vapor.

35.2. Notícias.

35.2.1. À luz da ribalta

Notícias sobre as peças em cartaz na cidade.

35.2.2. Despedida da companhia Tina di Lorenzo. 
35. Vida Paulista, número 131, 09 e 10/08/1908, ano III

35.1. Peças de teatro, homenagens à classe teatral, escritos diversos de autores consagrados

35.1.1 AZEVEDO, Artur. A vacina.

Teatro a vapor

35.2. Notícias.

35.2.1. À luz da ribalta

Notícias sobre as peças em cartaz na cidade.

35. Vida Paulista, número 133, 23 e 24/08/1908, ano III 35.2. Notícias.

35.2.1. À luz da ribalta

Notícias sobre as peças em cartaz na cidade.

35. Vida Paulista, número 134, 30 e 31/08/1908, ano III 35.2. Notícias.

35.2.1. Artigo elogiando a atriz Maria Guerrero

35.2.2. À luz da ribalta

Notícias sobre as peças em cartaz na cidade.

35. Vida Paulista, número 135, 06 e 07/09/1908, ano III 35.2. Notícias.

35.2.1. À luz da ribalta

Notícias sobre as peças em cartaz na cidade.

35. Vida Paulista, número 137, 20 e 21/09/1908, ano III

35.3. Crítica Teatral

35.3.1. Qual foi a origem da opereta?

Artigo anônimo sobre a invenção da opereta.

35. Vida Paulista, número 138, 27 e 28/09/1908, ano III 35.3. Crítica Teatral

20.1.1. A nudez no teatro.

O artigo diferencia o nu artístico do nu pornográfico, ao comentar o pronunciamento da Câmara de Paris sobre os processos instaurados contra diretores de casas de espetáculos e algumas dançarinas. 
35.5. Fotos e charges

35.5.1. Figura de Sardou durante um ensaio de Theodora.

\section{Vida Paulista}

Os números abaixo relacionados não apresentam artigos sobre teatro.

número 139, 04 e 05/10/1908, ano III

número 132, 16 e 17/08/1908, ano III

número 136, 13 e 14/09/1908, ano III 